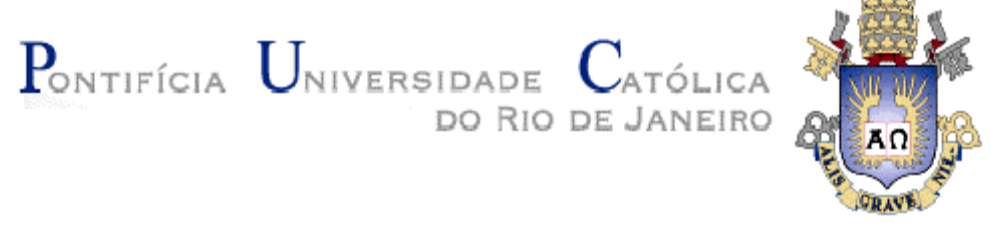

Isabel Victória Corrêa Van Der Ley Lima

\title{
O ESTÁGIO EM MUSEUS DE CIÊNCIA: \\ O Museu como Espaço de Produção do Conhecimento e Formação
}

\section{Tese de Doutorado}

Tese apresentada como requisito parcial para a obtenção do grau de Doutor pelo Programa de PósGraduação em Educação do Departamento de Educação da PUC-Rio.

Orientadora: Prof ${ }^{\mathrm{a}}$. Maria Cristina Monteiro Pereira de Carvalho

Rio de Janeiro

Janeiro de 2018 


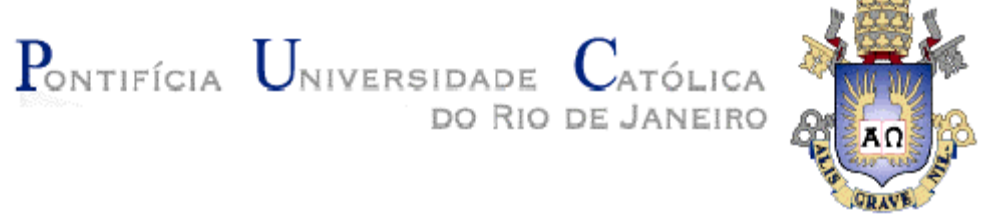

Isabel Victória Corrêa Van Der Ley Lima

\section{O ESTÁGIO EM MUSEUS DE CIÊNCIA: \\ O Museu como Espaço de Produção do Conhecimento e Formação}

Tese apresentada como requisito parcial para a obtenção do grau de Doutor pelo Programa de Pósgraduação em Educação do Departamento de Educação do Centro de Teologia e Ciências Humanas da PUC-Rio. Aprovada pela Comissão Examinadora abaixo assinada.

Prof ${ }^{a}$. Maria Cristina Monteiro Pereira de Carvalho Orientadora Departamento de Educação - PUC-Rio

Prof ${ }^{a}$. Rosália Maria Duarte Departamento de Educação - PUC-Rio

Prof. Pedro Pinheiro Teixeira Departamento de Educação - PUC-Rio

Prof ${ }^{a}$. Sibele Cazelli

Ministério da Ciência e Tecnologia, Inovações e Comunicações

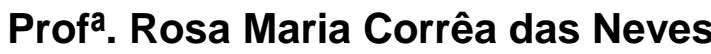
Escola Politécnica de Saúde Joaquim Venâncio - FIOCRUZ

Profa. Monah Winograd Coordenadora Setorial do Centro de Teologia e Ciências Humanas - PUC-Rio 
Todos os direitos reservados. É proibida a reprodução total ou parcial do trabalho sem autorização da universidade, da autora e da orientadora.

\section{Isabel Victória Corrêa Van Der Ley Lima}

Possui graduação em Ciências Biológicas (Bacharelado em Biologia Marinha em 2004 e Licenciatura Plena em 2007) pela Universidade Federal do Rio de Janeiro (UFRJ) e mestrado em Biologia Marinha pela Universidade Federal Fluminense (UFF). É professora do setor de Ciências Biológicas do Colégio de Aplicação da UFRJ e integrante do Grupo de Estudo e Pesquisa em Educação, Museu, Cultura e Infância (GEPEMCI) do Departamento de Educação da Pontifícia Universidade Católica do Rio de Janeiro (PUC-Rio).

Ficha Catalográfica

Lima, Isabel Victória Corrêa Van Der Ley

O estágio em museus de ciência : o museu como espaço de produção do conhecimento e formação / Isabel Victória Corrêa Van Der Ley Lima ; orientadora: Maria Cristina Monteiro Pereira de Carvalho. - 2018.

196 f. : il. color. ; $30 \mathrm{~cm}$

Tese (doutorado) - Pontifícia Universidade Católica do Rio de Janeiro, Departamento de Educação, 2018.

Inclui bibliografia

1. Educação - Teses. 2. Iniciação científica. 3. Formação científica. 4. Extensão universitária. 5. Educação em Museus. 6. Mediação. I. Carvalho, Maria Cristina Monteiro Pereira de. II. Pontifícia Universidade Católica do Rio de Janeiro. Departamento de Educação. III. Título. 
Dedico este trabalho a todos os que foram meus professores desde o início da minha vida escolar até o doutorado. Mestres que, como diria Paulo Freire, ajudaram a transformar minha curiosidade ingênua em curiosidade epistemológica.

E aos meus alunos, que a partir do diálogo, me tornam professora e inspiraram esta pesquisa. 


\section{Agradecimentos}

Sonho que se sonha só

É só um sonho que se sonha só Mas sonho que se sonha junto é realidade

(Raul Seixas - Prelúdio)

É praxe agradecer em primeiro lugar às agências de fomento. Mas agradecer à essas agências neste trabalho, supera a mera convenção acadêmica, pois o próprio objeto investigado só existe porque há o financiamento público à pesquisa em nosso país. Assim, agradeço à Capes, pela bolsa concedida para que eu, enquanto professora da educação básica, pudesse me tornar pesquisadora, ao longo desse processo de doutoramento.

Agradeço também à minha querida orientadora Cristina Carvalho, por ter aceitado a aventura de pensar sobre as dimensões formativas na iniciação científica e por ter me apresentado o fascinante mundo da Educação em Museus. Por ter me orientado sempre de forma presente e entusiasmada. Ter conhecido e convivido com a Cristina nesses quatro anos, sem dúvidas, foi uma das coisas que fez essa formação ter valido a pena. Não posso deixar também de agradecer as excelentes contribuições para a escrita da tese.

Agradeço também à banca examinadora deste trabalho, em especial às professoras Rosalia Maria Duarte e Sibele Cazelli, que participaram dos meus exames de qualificação, contribuindo com sugestões valiosas para a estruturação da tese e à Rosa Maria Neves, que além de ser referência para esta pesquisa, me ouviu e deu importantes sugestões. Agradeço aos professores Pedro Pinheiro Teixeira, e Ozias de Jesus Soares por também terem aceitado compor a banca examinadora, tendo feito avaliações e contribuições de extrema relevância para esse trabalho.

Aos professores do Departamento de Educação da PUC-Rio, por terem me acolhido tão bem. As aulas e a convivência permitiram que eu mudasse minhas perspectivas teóricas do campo da Biologia para o campo da Educação. Agradeço em especial 
aos professores Marcelo Andrade (em memória), Alicia Bonamino e Rosalia Duarte, coordenadores do programa de pós-graduação no período em que fui aluna. Pessoas que sempre me receberam com boas palavras e sorrisos. Em especial ao Marcelo, do qual tenho um ensinamento para cada momento em que tive o privilégio de estar ao seu lado ao longo desses anos.

Aos funcionários da PUC-Rio, que a partir do seu trabalho, constroem esta universidade, e em especial aos funcionários do departamento de educação, dos quais destaco a Marnie Oliveira, secretária da pós-graduação, por sempre ter me recebido de forma tão eficiente e solícita.

Ao Grupo de Estudo e Pesquisa em Educação, Museus Cultura e Infância (GEPEMCI), onde encontrei muito apoio acadêmico e afetivo durante o trabalho. Em especial à Thamiris Lopes Bastos que me ajudou com bibliografias, estruturação do texto e instrumentos de coleta de dados e à Isabel Mendes que contribuiu com referências e me ajudou na entrada no campo para a pesquisa.

Aos meus colegas do Colégio de Aplicação da UFRJ, por todo apoio e incentivo a meu doutoramento, sempre reconhecendo a importância de uma professora da educação básica se formar como pesquisadora.

À equipe do setor de Ciências Biológicas do CAp: Carla Maciel, Filipe Porto, Maria Matos e Natália Rios, onde mais do que colegas de trabalho, reconheço amigos, com os quais compartilho sonhos, ideias e ideais sobre o ensino de ciência, a escola e a universidade pública, gratuita e de qualidade. Aos professores, Ana Carolina Cunha, Aline Machado, André Micaldas, Ângela Bouzan, Bruno Althoff, Camila Suizani, Felipe Bastos, Pedro Teixeira e Vinícius Zanini, que compuseram a equipe de Biologia durante esses últimos quatro anos. Seus trabalhos éticos, comprometidos e dedicados à instituição permitiram que eu pudesse me dedicar com tranquilidade à minha formação, em especial nos últimos oito meses em que estive em licença para estudos. Agradeço também às professoras Mariana Vilela e Jacqueline Girão parceiras de trabalho e de vida e por todo incentivo para que eu cursasse essa etapa da minha formação acadêmica. 
À Associação Brasileira de Pesquisa em Educação em Ciências, pela oportunidade de ter participado da VI Escola de Formação de Pesquisadores em Educação em Ciências e em especial às professoras Sandra Selles, Martha Marandino e Isabel Martins com as quais aprendi tanto diretamente a partir do diálogo e indiretamente a partir de suas obras que são referências para a Educação em Ciências no Brasil.

Aos entrevistados para esta pesquisa, que a despeito de serem pessoas tão ocupadas me receberam em seus espaços de trabalho e aos que responderam aos questionários à distância. Sem a participação desses sujeitos, não haveria esta pesquisa.

À minha querida turma de doutorado, ao final do curso apelidada de coorte 2014, por toda a troca durante o processo. Nossa convivência reforçou entre nós o entendimento de que é possível produzir conhecimento na pós-graduação com dedicação, ética, solidariedade e afeto. E aos companheiros de mezanino Cristina Freund, Renato Pontes, Raquel Pinho, Rachel Pulcino e Felipe Bastos por todo apoio, incentivo e risadas no período da escrita deste trabalho.

À amiga Wanda Castro pelo auxílio com o resumo na língua inglesa.

Às pessoas que estiveram do meu lado durante essa caminhada, entendendo as ausências e dando suporte para que eu continuasse. Ao meu companheiro (no real sentido da palavra) Edgard Gil Bessa, por além do apoio afetivo, ter ajudado na elaboração do trabalho, formatação, impressão, entre outros. Não teria chegado até aqui sem sua ajuda.

Às amigas-irmãs Clara-Luz da Aurora dos Santos, Karine Bastos e Luiggia Girardi, pelos momentos de apoio e risadas. Sem todo o afeto, escuta e alegria, não teria chegado até o fim desse processo.

À minha mãe, Ana Lourdes Assaf Corrêa, sem a qual nada disso seria possível. Por ter feito tantos sacrifícios em momentos tão difíceis que vivemos para que eu pudesse me dedicar aos estudos. Por todo o companheirismo durante minha jornada na academia e na vida. Essa conquista é nossa! 


\section{Resumo}

Lima, Isabel Victória Corrêa Van Der Ley; Carvalho, Maria Cristina Monteiro Pereira de (orientadora). O estágio em museus de ciência: o museu como espaço de produção do conhecimento e formação. Rio de Janeiro. 196 p. Tese de Doutorado - Departamento de Educação, Pontifícia Universidade Católica do Rio de Janeiro.

O presente trabalho tem como objetivo caracterizar o estágio desenvolvido por alunos bolsistas em museus de ciência. Historicamente, esses espaços se consolidaram como locais de produção de conhecimento e educação. Em um primeiro momento, pretendeu-se investigar exclusivamente como a iniciação científica (IC) ocorre nesses espaços e se a formação dos bolsistas se relaciona com as demais atividades museais, como a mediação. Assim, foram levantados quais museus da cidade do Rio de Janeiro possuem bolsistas de IC e, em seguida, realizou-se entrevista com os profissionais das instituições responsáveis por esses alunos. Entretanto, a ida a campo revelou a presença de outros tipos de bolsa, como a de extensão universitária, levando, portanto, a ampliar os objetivos da investigação, ou seja, incluiu-se a análise da formação dos bolsistas em geral. Buscou-se também, a partir da aplicação de um questionário online, mapear os demais espaços museais no país que possuem alunos bolsistas. A investigação permitiu a caracterização do estágio quanto à seleção dos bolsistas, atividades desenvolvidas, apresentação dos resultados, avaliação e relação com a mediação. Para a análise das dimensões formativas na IC, estabeleceu-se um diálogo com autores como Latour, Bourdieu, Neves e Martins, e na extensão, com Freire e Paula. A análise das experiências formativas mostrou que a extensão e os museus de ciência podem ser espaços para o diálogo entre o conhecimento científico e a sociedade, onde a produção do conhecimento e a educação, em geral, caminham juntos. Além disso, a pesquisa aponta que a IC e a extensão são processos formativos que podem acontecer simultaneamente e o quanto museus de ciência parecem ser um espaço potente para que essas diferentes formações acadêmicas aconteçam em diálogo. 


\section{Palavras-chave}

Iniciação Científica; Formação Científica; Extensão Universitária; Educação em Museus; Mediação em Museus. 


\section{Abstract}

Lima, Isabel Victória Corrêa Van Der Ley; Carvalho, Maria Cristina Monteiro Pereira de (Advisor). Internship in Science museums: the museum as a space for producing knowledge and academic background. Rio de Janeiro, 2018. 196 p. Tese de Doutorado - Departamento de Educação, Pontifícia Universidade Católica do Rio de Janeiro.

This work aims to characterize the internship developed by scholarship students in Science museums. Those places have been historically recognized as places of production of knowledge and education. At first, our intention was to investigate exclusively how the work of initial scientific research-training programs (IST) is developed in those spaces and if the academic background of the scholarship students has any relation to other museum activities, like mediation. Thus, we first gathered information about what museums in Rio de Janeiro had intern students who held IST scholarships and then we interviewed the professionals who were directly responsible for those students. However, the field work revealed other types of scholarships, what led us to broaden our goals, which means including the analysis of all scholarship holders. We have also tried to map others museum in the country that had scholarship students and we did that using an online questionnaire. The investigation allowed us to characterize the internship regarding the selection of the scholarship holders, the activities in which they were involved, presenting results, evaluation and how they related to the mediation. In order to perform the analysis of the academic background dimensions in the scientific initiation of grad students, we stablished a dialog with authors like Latour, Bourdieu, Neves and Martins and for the analysis of the work of extension students, we used Freire and Paula. The analysis of the academic background forming experiences showed that the university extension and the science museums can be places where the scientific knowledge and the society can dialogue, where the production of the knowledge and the education generally walk together, side by side. Besides, the research shows that the scientific initiation and the extension are academic background forming processes that can happen simultaneously, and also 
how much science museums can be great places where those different academic background formations can relate to each other.

\section{Keywords}

Initial scientific Research-training Programs; Scientific Formation; University Extension; Museums Education; Mediation. 


\section{Sumário}

1. Introdução 18

1.1. Objetivo 22

1.1.1. Objetivos Específicos 23

1.2. Metodologia 23

2. Ciência - o que é e como é feita 28

2.1. A Ciência do ponto de vista epistemológico 28

2.2. Onde a Ciência é produzida? Um pouco da história 35

2.3. A produção da Ciência no Brasil 38

3 . Iniciação Científica - histórico e características 44

3.1. A pós-graduação brasileira como instância de formação e produção do conhecimento 44

3.2. A Iniciação Científica 48

3.3. A Iniciação Científica no ensino médio 54

3.3.1. Os Programas de IC-EM no Estado do Rio de Janeiro 56

4 . Museus - espaços para a produção do conhecimento e educação 62

4.1. O papel da educação nas instituições museais 65

4.2. Os museus de ciências e a produção do conhecimento 67

4.2.1. Primeira geração: os museus de História Natural 68

4.2.2. Segunda geração: ciência e indústria 69

4.2.3. Terceira geração: fenômenos e conceitos científicos 70

4.3. O papel da mediação na educação em museus 72

5. O estágio de alunos bolsistas em museus de ciência 80

5.1. Os museus estudados 81

5.1.1. O Museu Nacional 83

5.1.2. O Espaço Ciência Viva 86

5.1.3. O Museu de Astronomia e Ciências Afins (MAST) 87

5.1.4. O Espaço COPPE Miguel Simoni 91

5.1.5. O Museu da Vida 92

5.1.6. O Museu da Química Athos da Silveira Ramos 95 
5.2. O perfil dos profissionais entrevistados

5.3. Os tipos de bolsas $\quad 99$

5.4. Atividades desenvolvidas pelos alunos bolsistas 104

5.4.1. Os processos seletivos 104

5.4.2. As atividades desenvolvidas pelos bolsistas 114

5.4.3. Apresentação dos resultados pelos bolsitas 118

5.4.4. Avaliando o processo formativo 123

5.4.5. E o aluno, avalia o processo? 127

5.5. A formação dos bolsistas nos demais museus de ciência do país 130

6 . Os processos formativos encontrados no estágio em museus de ciência

6.1. A interface do estágio com a mediação - o museu como espaço para a formação de educadores

6.2. A Iniciação Científica e a formação de pesquisadores 148

6.2.1. Iniciação científica com bolsas de outra natureza 153

6.3. A extensão universitária como espaço de formação 163

7. Considerações Finais 176

8. Referências bibliográficas 183

Apêndices 192

Apêndice 1 - Roteiro de entrevista 192

Apêndice 2 - Termo de consentimento livre e esclarecido 194

Apêndice 3 - Questionário enviado aos museus de ciência 195 


\section{Lista de Figuras}

Figura 1: Foto da fachada do Museu Nacional.

Figura 2: Foto do interior do Museu Nacional, com parte da exposição do acervo de paleontologia..

Figura 3: Foto da fachada do galpão onde funciona o Espaço Ciência Viva.

Figura 4: Foto do interior do galpão onde funciona o Espaço Ciência Viva.

Figura 5: Foto da fachada do Museu de Astronomia e Ciências Afins. 88 Figura 6: Foto de exposição na área externa do MAST sobre observações do Recife holandês.

Figura 7: Foto da fachada do Centro de Tecnologia da UFRJ onde está localizada a COPPE.

Figura 8: Foto de parte da exposição permanente do Espaço COPPE. 92 Figura 9: Foto da fachada do Castelo Mourisco da Fiocruz.

Figura 10: Foto de modelo de célula localizado no espaço Parque da Ciência do Museu da Vida.

Figura 11: Foto de parte do acervo do Museu da Química. 


\section{Lista de Tabelas, Gráficos e Quadros}

Tabela 1: Número de museus existentes em cada região e Estado brasileiro e de instituições que responderam ao questionário.

Tabela 2: Formas de apresentação dos resultados do estágio nos museus e centros de ciência investigados

Tabela 3: Formas de avaliação dos bolsistas nos museus e centros de ciência investigados

Tabela 4: Formas que os alunos bolsistas têm de avaliar seu estágio nos museus e centros de ciência investigados

Tabela 5: Causas apontadas pelos museus e centros de ciência investigados para a ausência de alunos bolsistas

Gráfico 1: Total de instituições existentes, respondentes e com bolsistas por região geográfica brasileira.

Gráfico 2: Tipos de bolsa ofertadas pelos museus que possuem alunos bolsistas

Quadro 1: Dados dos Programas de IC-EM do Estado do Rio de Janeiro

Quadro 2: Perfil dos funcionários responsáveis pelos alunos bolsistas de IC nos museus de ciência da cidade do Rio de Janeiro

Quadro 3: Divergência de respostas sobre a presença de bolsistas de IC (ensino médio e graduação) nos questionários e entrevistas 100 Quadro 4: Tipos de bolsas presentes nas instituições pesquisadas 103 Quadro 5: Cursos de origem dos bolsistas ligados às atividades educativas. 


\section{Lista de Sigla}

ABCMC - Associação Brasileira de Centros e Museus de Ciência

CAp - Colégio de Aplicação

Capes - Coordenação de Aperfeiçoamento de Pessoal de Nível Superior

CBPF - Centro Brasileiro de Pesquisas Físicas

CNAP - Centros Nacionais de Aperfeiçoamento Pós-graduado

CNPG - Conselho Nacional de Pós-graduação

CNPq - Conselho Nacional de Desenvolvimento Científico e Tecnológico

COEDU - Coordenação de Educação em Ciências

COC - Casa de Oswaldo Cruz

COPPE - Instituto Alberto Luiz Coimbra de Pós-graduação e Pesquisa de Engenharia da UFRJ

ECV - Espaço Ciência Viva

EPJV/FIOCRUZ - Escola Politécnica de Saúde Joaquim Venâncio da Fundação Oswaldo Cruz

Finep - Financiadora de Estudos e Projetos

Fiocruz - Fundação Oswaldo Cruz

Funtec - Fundo Tecnológico

GMA - Grupo Memória da Astronomia

GTC - Grupo técnico de Coordenação

IBICT - Instituto Brasileiro de Informação em Ciências e Tecnologia

IC - Iniciação Científica

IC-EM - Iniciação Científica no ensino médio

IC-Jr. - Iniciação Científica Júnior

ICJ - Programa de Iniciação Científica Júnior

IMPA - Instituto de Matemática Pura e Aplicada

INPA - Instituto Nacional de Pesquisas da Amazônia

LIC-Provoc - Laboratório de Iniciação Científica na Educação Básica

MAST - Museu de Astronomia e Ciências Afins

MCTIC - Ministério de Ciência, Tecnologia, Inovações e Comunicações 
MP - Medida Provisória

MUTEC - Museu Tecnológico da COPPE

NIC-Jr. - Núcleo de Iniciação Científica Júnior

OBMEP - Olimpíadas Brasileiras de Matemática das Escolas Públicas

PIC-Jr./CPII - Programa de IC-Jr. do Colégio Pedro II

PIC-OBMEP - Programa de Iniciação Científica das Olimpíadas Brasileiras de Matemática das Escolas Públicas

PJTC - Programa Jovens Talentos para a Ciência

PL - Projeto de Lei

PMAC - Projeto Memória da Astronomia no Brasil e Ciências Afins

PNPG - Planos Nacionais de Pós-graduação

PPGMus - Programa de Pós-Graduação Interunidades da Universidade de

São Paulo

PPGP-MUS - Programa de Pós-Graduação em Museologia e Patrimônio

Pró-Cultural - Programa de Iniciação à Produção Cultural

PROPOP - Programa de Iniciação à Divulgação Científica e Popularização da Ciência

Provoc - Programa de Vocação Científica da Fundação Oswaldo Cruz

SIAC - Semana de Integração Acadêmica

Unirio - Universidade Federal do Estado do Rio de Janeiro

UFRJ - Universidade Federal do Rio de Janeiro 


\section{1. Introdução}

A Iniciação Científica (IC) é um processo onde o aluno vivencia atividades que possam promover o diálogo de sua formação com a pesquisa. Essa iniciação ocorre a partir do envolvimento do aluno com programas de treinamento, desenvolvimento de estudos sobre metodologias científicas e através de visitas a espaços de produção do conhecimento, como laboratórios, institutos de pesquisa e universidades. Entretanto, é mais comum associar a IC ao engajamento dos alunos a um projeto de pesquisa, que será elaborado e realizado sob a orientação de um docente, executado com ou sem bolsa (MASSI e QUEIROZ, 2015).

Alguns autores evocam a possibilidade de, na IC, o aluno ter uma real compreensão do fazer científico, ou seja, de como se dá o trabalho dos cientistas e a produção do conhecimento científico. Além disso, esse processo formativo seria um caminho para a socialização do aluno em um meio acadêmico do qual ele fará parte. $\mathrm{Na}$ análise de Filipeck e colaboradores (2006), a partir da reflexão de Latour e Woolgar (1997), quando o estudante participa de diversas atividades de um laboratório que produz ciência é que ele aprende que "fazer ciência"1 é um processo em construção que envolve verbas, força de trabalho, instrumentos, objetos, argumentos e inovações. "A inserção do estudante no ambiente de pesquisa permite que o jovem conheça quem são as pessoas que estão fazendo ciência e como são distribuídas as responsabilidades nesse espaço" (FILIPECKI, BARROS e ELIA, 2006, p. 213).

Através da IC o aluno passa a frequentar um ambiente de pesquisa, vivenciar o cotidiano do fazer científico e, aos poucos, vai se familiarizando com ritos, técnicas e tradições de um campo do conhecimento. No Brasil, esse modelo de formação de pesquisadores foi construído a partir do

\footnotetext{
${ }^{1}$ Aspas dos autores.
} 
protagonismo das universidades e programas de pós-graduação como espaços para a produção da pesquisa científica e da necessidade de formar pesquisadores em um menor intervalo de tempo.

O interesse em estudar a Iniciação Científica como processo formativo teve início após meu ingresso como docente efetiva de Biologia no Colégio de Aplicação da Universidade Federal do Rio de Janeiro (CAp/UFRJ) em 2011. No CAp, muitos alunos participam de atividades de IC na universidade ou em centros de pesquisa. Na verdade, há alunos de ensino médio envolvidos em atividades de iniciação científica em parceria com outras instituições desde 1990, mas, em 2001, devido ao crescimento e complexidade desse tipo de formação, o colégio criou um setor específico para coordenar o processo de distribuição e acompanhamento dos alunos - o Núcleo de Iniciação Científica Júnior (NIC-Jr.). O Núcleo tem, portanto, a função de organizar as ações, ampliar a participação de instituições, pesquisadores e alunos, facilitar a obtenção de recursos e dar visibilidade às atividades desenvolvidas² .

Embora eu não atue no NIC-Jr., ou tenha qualquer contato com o trabalho dos alunos nos laboratórios ou grupos de pesquisa em que os alunos realizam seus estágios de IC, algumas questões foram levadas para a sala de aula por esses discentes. Era comum, por exemplo, que alguns alunos apresentassem suas dúvidas sobre conteúdos tratados em seus projetos de pesquisa. Quando questionava por que eles não tiravam as dúvidas diretamente com seus orientadores, alguns manifestavam vergonha de demonstrar que desconheciam determinado conteúdo para o professor da universidade, ou declaravam que tinham pouco acesso a seus orientadores. Os depoimentos desses alunos me fizeram pensar sobre qual seria o objetivo dos processos de IC voltados para o ensino médio (IC-EM ou IC-Jr.). Meu desejo era entender melhor como se dá o processo de IC realizado nas universidades por alunos que ainda não terminaram a educação básica. Por que os programas IC-EM ou IC-Jr. foram criados? Com que objetivo(s)? Como esses programas se dão na prática? Existe uma preocupação com relação à visão de ciência ensinada? Qual é a

\footnotetext{
2 Disponível em: <http://cap.ufrj.br/index.php/2-uncategorised>. Acesso em: 8 mar. 2017.
} 
importância educacional-social desses programas? A partir minha da experiência profissional, esses questionamentos configuraram-se então em foco de interesse.

A inquietação sobre as questões relacionadas à IC ganhou força quando a equipe de Ciências Biológicas, na qual estou inserida, desenvolveu um trabalho de IC-EM ${ }^{3}$. Vale esclarecer que as bolsas de ICEM foram concedidas a minha equipe sem uma solicitação expressa no texto do projeto encaminhado à agência de fomento. Entretanto, o grupo avaliou que seria interessante realizar esse tipo de trabalho, aceitando, assim, as bolsas em nosso projeto. A concessão inesperada fez com que a equipe se reunisse para definir quais seriam os objetivos e metodologia do novo tipo de trabalho. Considerando que a atividade envolvia uma iniciação científica, refletimos também sobre que visões de ciência gostaríamos de apresentar aos alunos inseridos no projeto.

O trabalho desenvolvido foi tão satisfatório que a solicitação desse tipo de bolsas foi mantida pela equipe. Como as indagações permaneciam, decidi investigar o tema mais a fundo. Com o ingresso no doutorado, no Programa de Pós-graduação em Educação da PUC-Rio, pude, durante a realização das disciplinas, aprofundar as leituras sobre a temática da iniciação científica.

O levantamento bibliográfico e as leituras realizadas me fizeram perceber que, embora a IC se configure como um processo importante para a formação de pesquisadores no Brasil, com um crescente número nas últimas décadas de bolsas para esse tipo de formação, o tema ainda é pouco estudado (MASSI e QUEIROZ, 2010).

Paralelamente ao meu interesse pela IC, passei a integrar em 2015 o Grupo de Estudo e Pesquisa em Educação, Museus, Cultura e Infância $(\text { GEPEMCI })^{4}$ e cursei a disciplina Educação, Cultura e Museu. Até então,

\footnotetext{
${ }^{3}$ Trabalho desenvolvido de 2011 a 2013 com bolsistas dos programas Jovens Talentos da Fundação de Amparo à Pesquisa do Rio de Janeiro (FAPERJ) e Programa Institucional de Bolsas de Iniciação Científica para o Ensino Médio (PIBIC-EM) do Centro Nacional de Desenvolvimento Científico e Tecnológico (CNPq).

${ }^{4} \mathrm{O}$ GEPEMCI é um grupo de estudos e pesquisa criado em 2010 com o objetivo de investigar questões relativas aos espaços museais e suas estratégias educativas para o público, principalmente para o público infantil. Ele é vinculado ao Programa de PósGraduação em Educação da PUC Rio.
} 
nunca havia pensado nos museus como um espaço de produção de conhecimento e de formação. Meu contato com essas instituições tinha sido apenas a de visitante, seja por interesse próprio e espontâneo, ou como professora, levando meus alunos para visitas agendadas. A partir das reflexões do grupo de pesquisa, da disciplina e da aproximação com profissionais que trabalham em museus, pude repensar o papel dessas instituições. É importante considerar que as funções do museu (como instituição) sofreram mudanças ao longo da história. Mas, de acordo com a definição do Comitê Internacional de Museus (ICOM) ${ }^{5}$, os mesmos são considerados, atualmente, como instituições sem fins lucrativos, permanentes, a serviço da sociedade e de seu desenvolvimento, e abertos ao público, que adquirem, conservam, pesquisam, divulgam e expõem, para fins de estudo, educação e divertimento, testemunhos materiais do povo e seu meio ambiente.

A reflexão sobre os museus como um espaço de formação e produção do conhecimento fez com que me interessasse pela formação de pesquisadores nesses espaços. Será que a IC acontece em museus? Em caso positivo, de que modo o trabalho é desenvolvido? Existe diferença com relação à IC que ocorre nas universidades?

Os museus ligados às universidades também contam com alunos bolsistas de extensão universitária. Das três dimensões constitutivas da universidade - ensino, pesquisa e extensão -, a extensão foi a última a surgir. Os sentidos da extensão variam de acordo com o contexto em que passou a existir nos diferentes países e foi mudando ao longo da história das universidades, que também teve suas atribuições modificadas ao longo do tempo.

Inicialmente o papel da extensão era o de difundir a informação produzida nas universidades para o público externo e o de solucionar demandas tecnológicas do setor produtivo. Com o tempo e a pressão dos movimentos sociais, a extensão configurou-se como uma instância onde o conhecimento universitário passa a ser produzido em diálogo com a sociedade (PAULA, 2013).

\footnotetext{
${ }^{5}$ International Concil of Museums (ICOM), criado em 1946. A definição citada encontra-se no artigo $2^{\circ}-\S^{\circ}{ }^{\circ}$ de seu estatuto.
} 
A extensão hoje é, portanto, uma das funções atribuídas à universidade na qual se articulam o ensino e a pesquisa de forma indissociável. Essa atividade é entendida como um processo educativo, cultural e científico que viabiliza uma relação de diálogo e transformação entre a universidade e a sociedade (FOPROEX, 1999). Entretanto, a visão dialógica de extensão, que inclui a ideia dessa dimensão formativa como um espaço para a produção do conhecimento, não esteve sempre presente como atributo da extensão universitária, que sofreu (e ainda sofre) disputas conceituais ao longo de sua história na universidade brasileira.

O entendimento da extensão como um espaço para a formação e produção do conhecimento fez com que, ao longo desta pesquisa, surgissem questões relacionadas a essa dimensão formativa: qual é o papel formativo da extensão para os alunos? Há aproximações ou diferenças entre a formação na IC e na extensão? Qual o diálogo entre a formação em museus e a extensão universitária?

\section{1.}

Objetivo

Considerando a importância da iniciação científica para a formação de novos pesquisadores e o papel dos museus para a produção de conhecimento, o objetivo inicial desta pesquisa era investigar se havia alunos bolsistas de iniciação científica nos museus de ciência e, caso houvesse, como se daria esse processo de formação. A escolha por essa tipologia de museu se deve ao fato de que, historicamente, estiveram relacionadas à pesquisa e à formação científica.

O objetivo inicial se restringia a avaliar apenas os processos formativos na iniciação científica. Entretanto, a ida a campo revelou a presença de outros tipos de bolsa para alunos, o que fez com que o objetivo inicial da investigação fosse ampliado.

O objetivo passou a ser, portanto, investigar os processos de formação que ocorrem com alunos bolsistas de ensino médio e graduação durante o estágio em museus de ciências. 


\subsection{1.}

\section{Objetivos Específicos}

- Levantar quais museus de ciência no país oferecem bolsas para o estágio de alunos de graduação e ensino médio.

- Entender e descrever como acontece a IC em museus e se há diferenças no trabalho desenvolvido com alunos do ensino médio e graduação.

- Discutir se há diferenças na formação dos bolsistas de IC em relação à formação dos demais bolsistas.

- Avaliar se há relação entre a formação dos bolsistas e as atividades de mediação nos museus investigados.

\section{2. \\ Metodologia}

Como o objetivo inicial era investigar apenas as atividades de iniciação científica, o primeiro passo foi fazer um levantamento sobre quais museus teriam bolsistas de IC. No período em que comecei a pesquisa, o GEPEMCI estava iniciando uma investigação ampla sobre a educação em museus da cidade e em processo de elaboração de um questionário online 6 a ser encaminhado a todos os museus do município do Rio de Janeiro ${ }^{7}$. O questionário foi pré-testado e posteriormente encaminhado às $135^{8}$ instituições indicadas no Guia dos Museus Brasileiros (IBRAM, 2011) e no guia Museus - memórias e afetividades da secretaria de cultura do Estado do Rio de Janeiro (Secretaria de Estado de Cultura do Rio de Janeiro, 2013).

Aproveitei esse instrumento e inclui duas questões relativas ao meu tema de pesquisa, de modo a obter as informações iniciais para o seu desenvolvimento:

I) A instituição possui bolsistas de iniciação científica?

\footnotetext{
${ }^{6}$ O questionário foi elaborado utilizando-se a ferramenta Google Formulários. A ferramenta é gratuita e disponível em < https://www.google.com/int//pt-BR/forms/about/>. Acesso em: 01 dez. 2017.

7 Projeto de pesquisa "As crianças e os museus da cidade do Rio de Janeiro: conhecendo estratégias educativas e repensando uma pedagogia museal para crianças" sob coordenação da professora Cristina Carvalho.

${ }^{8}$ O questionário foi enviado em 2015, quando 99 museus e centros culturais, dos 135 listados nos guias, encontravam-se em funcionamento.
} 


\section{( ) $\operatorname{sim}($ ) não ( ) eventualmente}

II) Em caso positivo, em qual segmento eles estão inseridos? (Pode assinalar mais de uma alternativa).

\section{( ) ensino médio ( ) graduação}

Das 85 instituições que responderam ao questionário, 18 afirmaram possuir alunos de graduação bolsistas de IC e seis declararam possuir bolsista de IC-EM. Dos museus que retornaram o questionário, 10 são museus de ciência e seis deles afirmaram possuir bolsistas de IC: o Museu Nacional da UFRJ, o Espaço Ciência Viva, o Museu de Astronomia e Ciências Afins, o Espaço COPPE Miguel Simoni, o Museu da Vida e o Museu da Química Athos da Silveira Ramos. Deste grupo de seis museus, todos possuíam bolsistas de graduação e três afirmaram que também possuíam bolsistas de ensino médio.

Para entender como se dava a formação dos alunos nesses espaços, decidi entrevistar os funcionários responsáveis pelos bolsistas nesses seis museus. As entrevistas foram realizadas a partir de um roteiro semiestruturado, construído para que se pudesse compreender aspectos básicos da formação dos alunos. A elaboração do roteiro se baseou em pesquisas feitas sobre a IC e na resolução normativa № 17/06 para a concessão de bolsas do Programa Institucional de Bolsas de Iniciação Científica (BRASIL. CNPq, 2006). Com o intuito então de caracterizar esse tipo de formação, o roteiro possui questões que buscam investigar os critérios de seleção dos alunos, as atividades desenvolvidas, a participação dos alunos em jornadas e outros eventos científicos e as formas de avaliação do estágio.

$\mathrm{Na}$ realização da primeira entrevista, foi possível constatar que, embora a instituição visitada tenha indicado na resposta ao questionário que possuía bolsistas de IC, todos os estagiários possuíam na verdade bolsa de extensão universitária. A descoberta levou a uma reformulação no roteiro de entrevista, para que fosse possível investigar a formação dos estagiários em geral, independentemente do tipo da bolsa ${ }^{9}$. Embora o

\footnotetext{
9 Como a primeira a instituição visitada para a realização das entrevistas não possuía bolsistas de IC, a entrevista não foi efetivada. Retornei à instituição, já com o roteiro reformulado, e só então foi realizada a entrevista nesta instituição.
} 
objetivo da pesquisa tenha sido ampliado, manteve-se o recorte de investigar os museus de ciência que afirmaram possuir bolsista de IC no questionário do GEPEMCI.

O roteiro de entrevista foi, portanto, reformulado a partir dos novos objetivos da pesquisa (Apêndice 1). Em primeiro lugar, pretendeu-se, na construção deste instrumento, formular perguntas que permitissem conhecer o perfil dos profissionais entrevistados, como, por exemplo, qual era a sua formação e seu vínculo institucional. Também buscou-se levantar informações sobre o perfil dos alunos bolsistas (segmento de ensino, curso de origem).

Além disso, a construção do roteiro levou em consideração o objetivo de investigar os atributos do estágio, ou seja, de que forma essas atividades eram desenvolvidas (como era o processo de seleção dos alunos, quais tarefas eram atribuídas a eles, se apresentavam os dados construídos na pesquisa, se eram avaliados e se avaliavam o processo formativo). Por último, pretendeu-se investigar se o estágio tinha alguma relação com as atividades de mediação e, em caso positivo, como era a formação para que esses bolsistas atuassem nos espaços de mediação.

As entrevistas foram realizadas entre 07 de junho e 16 de agosto de 2016, nas próprias instituições investigadas. Todos os entrevistados assinaram um termo de consentimento livre e esclarecido (Apêndice 2). As entrevistas foram gravadas e tiveram duração entre 20 minutos e uma hora e sete minutos (duração média de 38 minutos). Os áudios foram transcritos integralmente, preservando-se a identidade dos entrevistados.

O texto original das entrevistas foi mantido nas transcrições originais, mas, neste trabalho, seguindo a recomendação de Duarte (2004), as frases dos entrevistados excessivamente coloquiais, interjeições, repetições, vícios de linguagem e erros gramaticais foram corrigidas, tomando-se 0 cuidado para que o sentido original não fosse alterado.

As categorias temáticas definidas a priori para a análise e descrição dos processos formativos nos estágios nos museus foram: (1) seleção; (2) atividades desenvolvidas; (3) apresentação dos resultados; (4) avaliação do processo; (5) avaliação do aluno; (6) mediação. As categorias foram codificadas e as transcrições analisadas com ajuda do programa Atlas TI. 
Durantes as análises foram criadas duas novas categorias: (7) participação em atividades de pesquisa e (8) formação de professores.

A escassez de pesquisas que investigassem o estágio de alunos de ensino médio e graduação em museus de ciência levou a uma tentativa de mapeamento do estágio nas demais instituições do país. Para a coleta dos dados necessários para a realização desta pesquisa foi então elaborado um novo questionário online ${ }^{10}$ (Apêndice 3), enviado aos 291 museus e centros de ciências cadastrados pela Associação Brasileira de Centros e Museus de Ciência (ABCMC). A redação das questões do questionário seguiram as recomendações de Moura e Ferreira (2005), incluindo questões fechadas, abertas e em escala. Ainda seguindo recomendações das autoras sobre a elaboração de questionários, antes do envio foi realizado um pré-teste com um profissional da área.

Esse mapeamento procurou investigar se havia outros museus de ciência oferecendo bolsas para alunos de ensino médio e/ou graduação e, em caso positivo, que tipos de bolsa, e se os processos formativos eram semelhantes aos encontrados nos museus da cidade do Rio de Janeiro.

Com o intuito de atingir os objetivos da pesquisa, nos capítulos seguintes, será apresentado um aprofundamento teórico sobre as temáticas relacionadas ao objeto investigado. No capitulo 2 , abordo o que é e como é produzido o conhecimento científico. Essa é uma reflexão necessária para entender o que significa formar um pesquisador $e$, consequentemente, o que significa iniciar um aluno nos ritos da pesquisa. Neste capítulo também apresento de que forma se institucionalizou a pesquisa científica e como se organizou a formação de pesquisadores no Brasil.

No capítulo 3, desenvolvo uma reflexão mais específica sobre a iniciação científica como processo formativo, qual sua história, função e quais aspectos já foram abordados sobre essa temática.

Já no capítulo 4 abordo alguns aspectos com relação à história das instituições museais, como, por exemplo, os caminhos percorridos para que assumissem um papel na produção do conhecimento e na formação de

${ }^{10}$ Esse questionário também foi elaborado utilizando-se a ferramenta Google Formulários e enviado para os e-mails disponibilizados pela direção da ABCMC. 
sujeitos. A ênfase das reflexões aqui apresentadas recai sobre os museus de ciência, que se configuraram como espaço para a realização da parte empírica desta pesquisa.

As características do estágio realizado por alunos bolsistas em museus de ciência estão descritas no capítulo 5 , e as dimensões formativas da iniciação científica e da extensão, bem como o diálogo do estágio em museus com as atividades de mediação, são discutidas no capítulo 6.

Ao final, são tecidas as considerações sobre as escolhas teóricas, limites metodológicos, achados da pesquisa e perspectivas futuras de investigações sobre a temática explorada neste trabalho. 


\section{2. \\ Ciência - o que é e como é feita}

Para a compreensão dos significados de iniciar um jovem no processo de produção do conhecimento científico, me parece importante pensar sobre o que é a ciência. $O$ que há de particular na forma de produção do conhecimento científico? Essa é uma reflexão importante para a compreensão do processo formativo de um novo pesquisador? Há várias formas de se pensar o que é a ciência. A análise pode ser epistêmica, filosófica, histórica, sociológica e até mesmo antropológica, se pensarmos na ciência como uma produção cultural humana. Neste capítulo, faço um exercício de olhar a ciência através de alguns desses campos de conhecimento. É claro que não se trata de esgotar as possibilidades de olhares, o que fugiria do objetivo desta pesquisa, mas de fornecer subsídios para entender, do ponto de vista da educação, o que significa o processo formativo que se dá na iniciação científica.

\section{1.}

\section{A Ciência do ponto de vista epistemológico}

Em seu livro "O que é a ciência afinal?", Chalmers tenta traçar um panorama sobre as principais teorias modernas que abordam a natureza da ciência (CHALMER, 1993). O trabalho do autor será utilizado para descrever algumas das diferentes formas de se compreender a natureza da ciência.

A ciência do início da era moderna era baseada no positivismo lógico de Francis Bacon ${ }^{11}$ (século $\mathrm{XVI}$ ), que tinha como meta da pesquisa melhorar as condições de vida do homem, alcançada por meio da coleta de fatos, observação organizada e teorias derivadas a partir delas. O método científico, dentro dessa lógica, segue o princípio indutivo. Para o indutivismo, a ciência começa da observação. $O$ corpo do conhecimento 
científico é então construído pela indução feita de forma segura a partir da observação. Essa indução permite a formulação de leis e teorias que levam, pelo raciocínio lógico, à dedução de previsões e explicações. Nessa visão, o crescimento da ciência é "contínuo, para frente e para o alto, conforme o fundo de dados e de observação aumenta" (CHALMERS, 1993, p. 27).

Ainda hoje, muitas pessoas, incluindo pesquisadores, têm essa compreensão positivista-indutivista. Um dos problemas do princípio da indução é que se baseia na observação e no princípio da lógica, de que se a premissa é verdadeira, a conclusão também deve ser. Chalmers (1993) cita o exemplo de que se observarmos corvos apenas pretos, podemos inferir que todos os corvos são pretos, mas isso não nos dá garantia lógica de que o próximo corvo que observarmos não será cor de rosa.

O argumento central para justificar a indução é circular, pois emprega um argumento indutivo de que se o princípio indutivo foi bem-sucedido em uma série de observações, ele será sempre bem-sucedido. Assim, usa-se a indução para justificar a indução.

Um outro problema dessa corrente é que para se fazer uma indução é necessário um grande número de observações em diferentes circunstâncias. Mas como se determina esse número de observações e a ampla variedade de circunstâncias necessárias para conferir confiabilidade à indução?

Nessa abordagem, também se configura como problema o fato do indutivismo partir dos pressupostos de que a ciência começa pela observação e de que a observação produz uma base segura da qual o conhecimento pode ser derivado. Chalmers (1993) chama atenção para o fato de que dois observadores nunca têm experiências perceptivas idênticas. Seja pelo sentido físico propriamente dito, seja em decorrência de formações culturais diferentes, conhecimentos prévios, expectativas distintas de cada observador. O autor também afirma que mesmo que houvesse uma experiência única dada a todos os observadores, em termos de percepção, todas as observações pressupõem e se orientam por teorias.

No início do século XX, a obra de filósofos da ciência como Popper e Bachelard apontavam críticas à visão positivista da ciência. Essa visão já 
não dava mais conta de explicar como de fato era produzido o conhecimento científico, e limitava o desenvolvimento de novos paradigmas em ascensão nas Ciências Naturais e nas Ciências Humanas. Popper foi um conhecido defensor do falsificacionismo. Ao contrário do indutivismo, o falsificacionismo admite que a observação é orientada pela teoria e a pressupõe. Um falsificacionista também não supõe que teorias podem ser estabelecidas como verdadeiras à luz de evidências observadas. Para essa corrente,

as teorias são interpretadas com conjecturas especulativas ou suposições criadas livremente pelo intelecto humano no sentido de superar problemas encontrados por teorias anteriores e dar uma explicação adequada do comportamento de alguns aspectos do mundo ou universo. Uma vez propostas, as teorias especulativas devem ser rigorosas e inexoravelmente testadas por observação e experimentos. Teorias não resistentes aos testes devem ser descartadas e substituídas por teorias especulativas ulteriores (CHALMERS, 1993, p. 63).

Para Popper, a ciência progride por tentativa e erro, por conjecturas e refutações. Mas não se poderá nunca dizer legitimamente que uma teoria é verdadeira, mas que ela é a melhor disponível naquele momento.

Assim como no indutivismo, o falsificacionismo também encontra limites em relação à questão das observações, pois a proposição de observações depende da teoria e são falíveis.

Uma outra crítica ao falsificacionismo é, que do ponto de vista da história da ciência, esse método nem sempre é seguido e muitas teorias não foram rejeitadas, embora tenham sido falsificadas e isso foi bom para a ciência, pois mais à frente essas teorias se mostraram mais adequadas.

Chalmers considera que tanto as visões indutivistas quanto falsificacionistas acerca da ciência são fragmentárias, pois ao se concentrarem nas relações entre teorias e nas proposições de observações, deixa-se de levar em conta as complexidades das teorias científicas, não sendo "capazes de produzir uma caracterização adequada da gênese e crescimento de teorias realisticamente complexas" (CHALMERS, 1993, p. 108).

Sendo assim, filósofos da ciência como Kuhn, Feyerabend e Lakatos focaram seus trabalhos nas teorias científicas, dando grande importância à 
história das ciências para entender as teorias e a própria ciência do ponto de vista epistemológico.

Kuhn se baseou na história da ciência para entender a construção da racionalidade científica. Até então, as correntes epistemológicas clássicas procuravam descrever procedimentos estandartizados empregados pelos pesquisadores ou adotavam posturas prescritivas, identificando ou normatizando o que seria singular na racionalidade científica. Mas, para Kuhn, tanto o modo verificacionista quanto o falsificacionista são formas idealizadas de reconstrução da racionalidade científica incapazes de apreenderem como as ciências tem de fato evoluído (OLIVA, 1994). Kuhn vê no verificacionismo e no falsificacionismo

uma espécie de supressão dos aspectos dinâmicos do processo de produção do conhecimento, como se representasse propostas idealizadas de procedimentos a operacionalizar nos contextos de pesquisa (OLIVA, 1994, p. 70-71).

A partir da análise da história da ciência e dos processos relacionados ao fazer científico, Kuhn tentou mostrar como as comunidades científicas impõem modelos de produção intelectual a seus membros.

A partir da crítica de Kuhn à epistemologia clássica, é possível perceber que, até então, a epistemologia da ciência leva pouco em consideração o fazer científico. Nesse sentido, a teoria desse filósofo sobre a ciência será útil para entender os processos de formação de pesquisadores. Utilizo então as reflexões de Oliva (1994) para traçar um breve panorama da filosofia da ciência construída por Kuhn, dando ênfase às questões referentes à formação de novos cientistas.

Ao contrário dos filósofos anteriores, Kuhn não estava preocupado em listar critérios para a cientificidade. Para ele, uma disciplina se tornaria científica porque funcionalmente ingressou em uma fase na qual os problemas passam a ser consensuais e unificadamente enfrentados com base em padrões estandartizados de abordagem. O funcionalismo kuhniano pretende descrever as atividades típicas da investigação científica em suas fases.

Kuhn considera que a ciência segue uma evolução a partir de uma ciência normal, onde há o consenso dentro de um paradigma, passando por uma crise, que leva a uma pesquisa extraordinária que culminará em 
uma revolução, a partir da qual se constitui um novo paradigma, iniciandose uma nova fase de ciência normal. O paradigma seria as realizações científicas universalmente reconhecidas que, durante algum tempo, fornecem problemas e soluções modelares para a comunidade científica. Assim, se cabe ao paradigma o que deve ser considerado um problema autêntico, não há um critério de cientificidade para todas as disciplinas, e o método será desenvolvido em função dos problemas acolhidos por cada ciência, não havendo, portanto, um método universal.

A existência de um paradigma é o que possibilita a tradição de investigação conhecida como ciência normal. Aqui é possível ressaltar os aspectos sobre a formação de novos pesquisadores, pois novos profissionais seriam treinados para a prática da ciência normal, e não para a extraordinária. A ciência normal é praticada por uma comunidade científica que compartilha uma matriz disciplinar.

O estudo do paradigma "é o que basicamente prepara o estudante para ser um membro de uma determinada comunidade científica na qual atuará mais tarde" (KUHN, 2013, p. 72). O estudante se reunirá aos sujeitos que aprenderam as bases do seu campo estudo e sua prática subsequente raramente irá provocar desacordo declarado a seus pontos fundamentais. Pessoas cujas as pesquisas estão baseadas em paradigmas compartilhados estão comprometidas com as mesmas regras e padrões para a prática científica. "Esse comprometimento e o consenso aparente que produz são pré-requisitos para a ciência normal, isto é, para a gênese e continuação de uma tradição de pesquisa determinada" (KUHN, 2013, p. 72).

Nesse sentido, o aluno que inicia sua formação científica se familiariza com os métodos e técnicas e os padrões de um paradigma. Entretanto, isso não significa que os processos de entrada de alguém na comunidade científica devam ser feitos de forma prescritiva, e sim, que formar-se pesquisador perpassa por inserir-se em um sistema de educação profissional muito complexo e disciplinador. 
Neves (2007) destaca que para Kuhn a teoria e literatura de referência (os Manuais ${ }^{12}$ ) de uma comunidade científica particular cumprem papel decisivo na renovação desta comunidade. Em sua formação, num primeiro momento, o iniciante aprende a teoria estudando-a e articulando-a com suas próprias pesquisas. Entretanto, a autora chama a atenção para o fato de que a filosofia de Kuhn não dá conta de explicar como esse aprendiz supera a condição de iniciante, para tornar-se um praticante da ciência.

Neste ponto, é possível a reflexão de que o entendimento acerca da epistemologia da ciência clássica pouco ajuda na compreensão do que significa formar um pesquisador, ou o que seria iniciar um aluno à ciência. Já as ideias de Kuhn (2013) ajudam a compreender de que modo essa formação se dá, sob o ponto de vista da sua inserção em uma comunidade científica a partir da vivência do aluno em um ambiente de pesquisa, onde ele aprenderá com os ritos e tradições de uma determinada área de conhecimento. Para Kuhn, a comunidade científica é a unidade produtora e legitimadora do conhecimento científico.

Convencido de que para compreender de fato como o conhecimento científico é produzido não bastava se basear apenas no que os cientistas dizem sobre si mesmos, Latour empreendeu um estudo etnográfico, no qual acompanhou o dia a dia dos cientistas de um laboratório de neuroendocrinologia nos Estados Unidos. Essa etnografia serviu de base para o livro que públicou com Woolgar: $A$ Vida de Laboratório. Para os autores, o laboratório seria o local da construção dos fatos, que envolvem pessoas, equipamentos, experiências, papéis e estratégias (LATOUR e WOOLGAR, 1997).

Destaca-se, na obra, a relevância da dimensão da escrita na produção do conhecimento e a ideia de que os fatos científicos são construídos. Em relação à escrita, os autores percebem que ela é a finalidade essencial da atividade dos cientistas e que depende de uma cadeia de operações que

[...] vão desde um primeiro resultado, rabiscado em um pedaço de papel e comunicado com entusiasmo aos colegas, até a classificação do artigo publicado nos arquivos do laboratório. Os inúmeros estágios intermediários

12 Os Manuais são livros que expõem o corpo da teoria aceita, ilustram suas aplicações e comparam essas aplicações com observações e experiências exemplares (KUHN, 2013). 
(conferências com projeções, difusão dos rascunhos etc.) têm relação, de uma forma ou de outra, com a produção literária (LATOUR e WOOLGAR, 1997, p. 70).

Os autores pontuam que os cientistas se veem como descobridores de fatos, quando na verdade atuam na maior parte do tempo como escritores e leitores que buscam se convencer e convencer aos outros.

Em relação a construção dos fatos, Latour e Woolgar percebem que os cientistas tendem a considerar como fato aquilo que se inscreve em um artigo. Assim, não consideram a sua construção social e a história da construção do fato em questão. "Um fato é reconhecido enquanto tal quando perde todos os seus tributos temporais e integra-se em um vasto conjunto de conhecimento edificado por outros fatos" (LATOUR e WOOLGAR, 1997, p. 102). Assim, os autores consideram que ao acompanhar o cotidiano de um laboratório, foi possível perceber que nele

são permanentemente produzidos documentos de natureza diversa, tendo por finalidade operar uma transformação em vários enunciados, transformações que Ihes confere ou subtrai o estatuto de fato científico (LATOUR e WOOLGAR, 1997, p.159).

Uma diferença marcante no trabalho etnográfico de Latour, como forma de compreender a ciência, é o a preocupação com as relações estabelecidas entre os sujeitos, evitando-se utilizar o cientista individual como ponto de partida ou unidade central de análise (HOCHMAN, 1994).

Hochman (1994) explica que, na visão de Latour e Woolgar, os pesquisadores assumem uma abordagem que se aproxima da econômica explicar as suas ações e suas relações. Em suas observações, Latour percebeu o uso de termos como investimento, oportunidade e retorno.

Sendo o cientista um investidor em credibilidade - recompensa, confiança, influência, reputação na capacidade de responder no futuro às expectativas e investimentos no presente -, ele avaliará a qualidade de suas informações, os seus receptores, as probabilidades de convencê-los e sua estratégia de carreira, e buscará, permanentemente, a conversão de uma forma de credibilidade em outras (HOCHMAN, 1994, p. 217).

Os epistemólogos da ciência, em sua maioria, acreditam que a confiabilidade dos dados seria algo totalmente distinto da avaliação dos indivíduos em determinada especialidade. Nessa perspectiva, o julgamento que se faz dos dados não estaria tão ligado à retórica de persuasão, assim como não deveria variar de acordo com o público que a interpreta, nem segundo o público para qual se dirigem os resultados. Mas, para Latour e 
Woolgar (1997), na verdade, esses julgamentos estão todos ligados a um ciclo de credibilidade e o pesquisador avalia ao mesmo tempo a qualidade dos dados, o nível do público e sua própria estratégia de carreira.

O trabalho de Latour e Woolgar foi um marco para um grupo de pesquisas que ficaram conhecidas como Estudos de Laboratório. Do ponto de vista metodológico, esses estudos avançam na compreensão da Ciência, pois passam a investigar a produção do conhecimento por meio das relações estabelecidas com o contexto social (MATTEDI, 2007).

Outra abordagem possível para entender a produção do conhecimento científico é através de uma abordagem histórica. Em particular, para que seja possível entender a formação de pesquisadores é interessante compreender a história da constituição da comunidade científica.

\section{2 . \\ Onde a Ciência é produzida? Um pouco da história}

Schwartzman (2015) tentou traçar, a partir de entrevistas, a história da formação da comunidade científica no Brasil. As reflexões aqui apresentadas pretendem tomar como foco a comunidade científica brasileira, considerando que a iniciação científica é uma política construída dentro da nossa história de formação de pesquisadores, aspecto explorado no capítulo seguinte, onde aprofundo a história e características da iniciação científica em si. Entretanto, é preciso, como o próprio autor explica, entender como a ciência foi produzida na Europa, e mais especificamente em Portugal, para que possamos compreender a história da produção do conhecimento acadêmico no Brasil.

Em geral, quando se pensa na produção do conhecimento, pensamos nas universidades e no conhecido tripé "ensino-pesquisa-extensão"; entretanto, como destaca Schwartzman (2015), a ciência experimental europeia se desenvolveu fora das universidades ${ }^{13}$. Essa ligação íntima entre a ciência e a universidade ocorreu apenas no século XIX. Até então, as universidades eram centros tradicionais de estudos clássicos e

\footnotetext{
${ }^{13}$ Essa seção do texto sobre a história da formação da comunidade científica é baseada no trabalho de Schwartzman (2015).
} 
ofereciam uma formação em direito, medicina e teologia, sendo o conhecimento científico experimental desenvolvido no interior das Sociedades Científicas. Essas sociedades tinham como mote criar coisas úteis e práticas, inclusive devido ao desenvolvimento do comércio e mais tarde da indústria. Mas, de acordo com Schwartzman,

Poucos dentre os principais membros dessas sociedades eram inventores de "coisas úteis", ${ }^{14} \mathrm{e}$ a força por trás do apoio e estímulo à pesquisa científica era a busca de uma forma original e inovadora de conhecimento do mundo, incorporada à ciência experimental. Estava sendo forjada uma visão completamente nova da natureza e dos métodos com que ela devia ser abordada, contrastando com a cultura tradicional que predominava nos meios acadêmicos (SCHWARTZMAN, 2015, p. 72).

Em países como Inglaterra e França, as Sociedades visavam desenvolver um conhecimento científico prático e aplicado, a serviço das elites do século XVII.

Durante o século XVIII, as universidades desses países sofreram mudanças que levaram a uma substituição da formação clássica para uma formação mais técnica. Nesse período as pessoas adquiriam conhecimentos fora da educação tradicional clássica, que se baseava fundamentalmente no estudo do grego, latim, lógica e filosofia. Havia então uma pressão, e o progresso das ciências empíricas mostrava que essa formação clássica era insuficiente.

Ainda nesse período, algumas instituições começaram a propor um tipo de educação muito mais técnica e especializada do que a oferecida pelas universidades tradicionais.

Essa nova visão de educação superior respondia a dois tipos de pressão: a necessidade de incorporar novos conhecimentos produzidos pela ciência experimental em expansão e a necessidade de eliminar privilégios especiais das profissões e corporações profissionais mais antigas, abrindo espaço para novas profissões, escolas, novos métodos de ensino e substituindo assim uma elite por outra (SCHWARTZMAN, 2015, p. 79).

Uma forte marca dessa mudança foi decorrente da Revolução Francesa, com a formação das escolas profissionais, e mais tarde, no período Napoleônico, com a criação das Escolas Politécnicas, voltadas para a formação de um corpo técnico para o Estado.

Foi na Alemanha, no entanto, que a pesquisa científica foi de fato introduzida na universidade no século XIX. No início do século, o sistema

\footnotetext{
${ }^{14}$ Aspas do autor.
} 
educacional prussiano sofreu uma reforma. Foi criada a Universidade de Berlim, com uma educação sob a égide de uma modernização do Estado. Os intelectuais da época viram na criação da universidade modernizada uma forma de garantir sua presença e importância, bem como de manter um sistema educacional integrado (sem uma dicotomia entre a formação clássica e técnica). Foi nesse sistema integrado que se uniu pela primeira vez ensino e pesquisa. Além disso, as universidades criadas existiam de forma independente, "competindo pelo talento disponível e ganhando prestígio com as realizações acadêmicas dos seus professores" (SCHWARTZMAN, 2015, p. 82). Neste contexto, os estudantes que pretendiam tornar-se professores tinham que aprender a realizar pesquisas científicas como parte da sua formação geral.

Embora essa associação entre ensino e pesquisa pareça óbvia hoje, o autor discute que há uma tensão entre o que se ensina, no sentido de se transmitir o que já é conhecido, e a pesquisa, que pretende conhecer o que é desconhecido. Mais tarde, esse modelo alemão foi incorporado ao sistema norte-americano, mas com uma importante inovação: a criação de escolas de pós-graduação e de cursos regulares de doutorado por meio das quais a atividade de pesquisa passou a ser reconhecida como uma profissão.

É possível perceber que os elementos presentes nas universidades alemãs (associação entre ensino e pesquisa, autonomia e disputa por talentos e uma formação dentro do processo de pesquisa) serviram de modelo para as universidades do resto do mundo ocidental.

A produção científica brasileira foi fortemente influenciada pela produzida em Portugal, que, embora, à princípio tenha desempenhado um pioneirismo no desenvolvimento das navegações, após o período renascentista passou a ter um papel marginal na produção científica europeia.

A partir do século $X V I$, foi criada a Companhia de Jesus que, em Portugal, teve forte influência na educação. No século XVIII, os jesuítas ditavam as regras para toda a educação, incluindo a educação universitária. Além das questões educacionais, a doutrina jesuíta, que tinha como norte as ideias de São Thomás de Aquino e Aristóteles, permeava a 
administração do Estado português. Com esse forte controle, o país ficou isolado de todas as transformações que ocorriam nas comunidades científicas modernas.

O cenário descrito acima foi alterado com as chamadas Reformas Pombalinas. Sebastião José de Carvalho e Melo, mais conhecido como Marquês de Pombal, fazia parte de um grupo de portugueses que viviam no exterior a serviço do rei. Pombal foi embaixador em Londres por muitos anos e após a morte de $\mathrm{D}$. João $\mathrm{V}$ foi convidado por seu sucessor, D. José I, a integrar o governo português. Neste período, Pombal foi de fato o governante, propondo mudanças. O Marquês valorizava o conhecimento científico e atribuía o sucesso da Inglaterra à aplicação do conhecimento científico às atividades produtivas.

Dentre as medidas relacionadas à educação, modernizou a Universidade de Coimbra, desde a sua infraestrutura até seus livros, e interferiu em programas e métodos de estudo. Mas o principal problema é que o pensamento científico precisava ser submetido a sua autocracia, porque, efetivamente, as reformas foram feitas para afirmar seu poder, limitando os poderes do príncipe. Com a centralização feita por Pombal, "a ciência moderna chegou a Portugal sem suas dimensões éticas e filosóficas" (SCHWARTZMAN, 2015, p. 94). Mesmo assim, a influência pombalina foi positiva, pois, no final do século, Portugal já contava com um número significativo de naturalistas, mineralogistas, botânicos. As invasões francesas colocariam fim a esse processo.

\section{3.}

\section{A produção da Ciência no Brasil}

Chegamos então à história da pesquisa no Brasil. De acordo com Schwartzman (2015), no período colonial, não havia educação superior organizada e as aulas elementares eram oferecidas pela Igreja. A chegada da corte portuguesa, em 1808, trouxe para a colônia muitas inovações e, na década seguinte, seriam criados os primeiros cursos superiores de engenharia e medicina. Ao contrário de países como França, Inglaterra e Holanda, que possuíam algum tipo de pesquisa nas colônias, Portugal, por não ter desenvolvido uma tradição científica, só tinha até então uma relação 
espoliativa com o Brasil. O pouco desenvolvimento tecnológico estava relacionado à mineração. Fora isso, as atividades científicas realizadas no Brasil até a independência tinham foco na descrição da natureza, que na maior parte das vezes eram realizadas por estrangeiros.

Em relação às instituições científicas, no final do século XVIII, já sob a influência das reformas pombalinas, foi fundada no Rio de Janeiro uma Sociedade Científica, e em 1797 foi fundada a primeira instituição oficial de pesquisa do Brasil, um jardim botânico na cidade de Belém/PA para a aclimatação de plantas. Foi apenas no século XIX, após a chegada da corte portuguesa, que começou a surgir alguns institutos técnicos e certas atividades de pesquisa mais sistematizadas. Foram fundadas as primeiras escolas de medicina na Bahia e no Rio de Janeiro, a Biblioteca Nacional, o Horto Real (hoje o Jardim Botânico do Rio de Janeiro) e a Academia Naval, uma academia militar que seria a primeira escola de engenharia do Brasil.

Essas instituições tinham um propósito pragmático e as escolas militares estavam relacionadas à falta de uma organização e desenvolvimento militar no Brasil. Da mesma forma, a criação das escolas de medicina estava relacionada a uma preocupação com a saúde pública.

Com o tempo, as academias militares se transformaram em escolas de engenharia, que não se destacaram como centros técnicos, mas configuraram-se como campo para o desenvolvimento de valores cientificistas do positivismo. As escolas médicas foram se desenvolvendo em torno das descobertas sobre as doenças tropicais. Também foram fundadas escolas de direito, em São Paulo e Recife, que longe do domínio do direito canônico e dos códigos lusitanos tradicionais, tiveram influência do pensamento liberal europeu.

Já o Jardim Botânico do Rio de Janeiro, teve a sua origem na fabricação de pólvora e na aclimatação de espécies de plantas. A partir de sua atividade, outros jardins botânicos foram criados em outras províncias. Após a Proclamação da Independência do Brasil, o Real Jardim Botânico, sob a administração de frei Leandro do Sacramento, que era então professor de Botânica na Escola de Medicina, teve a sua função ampliada e passou a funcionar como um instituto científico dedicado à experimentação. No mesmo período, o Museu Real (depois chamado de 
Museu Imperial e, finalmente Museu Nacional) iniciou sua coleção com amostras mineralógicas, objetos artísticos doados por D. João VI, artefatos nativos e animais empalhados de uma coleção iniciada na época colonial, conhecida como Casa dos Pássaros. Também após a independência, por apoio dos ministros do Império, o Museu passou a receber doações de naturalistas estrangeiros que visitavam o Brasil. Essas doações ampliaram o acervo e, à medida que o século progredia, o Museu se tornou um centro científico onde os naturalistas europeus se reuniam ao chegar ao Brasil.

$O$ apogeu da ciência no período imperial se deu com a presença do próprio imperador nos assuntos relacionados à ciência, à tecnologia e à educação. $O$ interesse de Dom Pedro II pelas ciências fazia com que ele patrocinasse e participasse de todos os eventos culturais e científicos importantes do país. Entretanto, essa participação do imperador sofria resistência de integrantes da comunidade científica, que entendiam que o interesse do imperador colocava essas atividades à mercê dos caprichos imperiais.

De fato, até o início da República, as atividades científicas no Brasil eram precárias. As decisões mantinham-se centralizadas nas mãos do imperador e não havia, como na Europa, setores que atribuíssem um valor à atividade científica que justificasse investimentos. A formação superior não tinha autonomia, assumindo objetivos utilitaristas.

Após a Proclamação da República, em 1889, foram criadas várias novas escolas e institutos, como o Instituto Butantã (1899) em São Paulo e o Instituto Manguinhos (1900) no Rio de Janeiro. As novas instituições científicas focavam pesquisas que buscavam resultados relacionados à exploração dos recursos naturais, à expansão da agricultura e o saneamento de portos e cidades. Vale destacar que, no período inicial da República, despontaram novas oligarquias cafeeiras em São Paulo e de pecuaristas em Minas Gerais (período que ficou conhecido como República do Café-com-Leite), e essas novas instituições eram estimuladas pelo crescimento da indústria e o desenvolvimento do transporte para 0 escoamento da produção, com a criação de novas ferrovias e portos. A ciência brasileira nesse período era fortemente influenciada pelos ideais 
positivistas, que, como destacado no capítulo anterior, entendia que o conhecimento científico gerava progresso e compreensão total do mundo.

$\mathrm{Na}$ década de 1920, com o aumento do número de intelectuais no país, a educação e a ciência passaram a ganhar destaque nos debates. Dentro desse clima de renovação, foram criadas a Academia Brasileira de Ciências (1922) e a Associação Brasileira de Educação (1924). A Academia Brasileira de Ciências tinha como papel central a promoção da ciência. Já a Associação Brasileira de Educação tinha como objetivo o desenvolvimento dos cursos primário, secundário e superior.

Os debates nesses novos espaços fortaleceram a ideia da criação da universidade brasileira, apontando para uma separação entre o ensino técnico das atividades científicas e da autonomia universitária. Naquele momento, muitos intelectuais rejeitavam a ideia de que a pesquisa deveria subordinar-se às necessidades práticas da nação ou à formação profissional, o que de fato acontecia até então.

A primeira universidade brasileira foi criada no Paraná em 1912, mas não teve uma vida longa. Em 1920, foi criada a Universidade do Rio de Janeiro, com a fusão das escolas de engenharia, medicina e direito. $\mathrm{Na}$ verdade, funcionava mais como um aglomerado de cursos do que como uma universidade de fato. Em 1931, surge a primeira legislação federal que delineia características para a universidade brasileira: a Reforma Francisco Campos $^{15}$ (Decreto 19.851/31). É importante destacar que esse é o período do Estado Novo, quando o governo passa a ser mais uma vez centralizado na figura do presidente Getúlio Vargas. A Reforma Francisco Campos aconteceu então quando um regime forte subia ao poder e "foi organizada claramente para paralisar o movimento favorável a um sistema universitário baseado em comunidades científicas organizadas de forma autônoma" (SCHWARTZMAN, 2015, p. 204). Neste contexto, o Estado, através da Reforma, acabou assumindo um papel tutelar sobre a universidade que nascia no Brasil. A Reforma de Campos também fez com que a universidade priorizasse a formação profissional em detrimento das atividades de pesquisa.

${ }^{15}$ Francisco Campos (1891-1968) foi ministro da educação e saúde entre 1930-32. 
Para Neves (2001), até a década de 1930, a possibilidade de seguir carreira científica implicava na convivência dos indivíduos em espaços científicos, principalmente nos institutos, com aproximação por laços pessoais e a realização do trabalho, sob orientação de uma grande figura da ciência.

A autora considera que a atividade científica como processo de profissionalização teve início somente após a fundação das primeiras universidades dedicadas a esse campo: a Universidade de São Paulo (1934), a Universidade do Distrito Federal (1935) e a Universidade do Brasil (1939). O processo de institucionalização da pesquisa científica brasileira é intensificado nas décadas seguintes, com a criação em 1949 do Centro Brasileiro de Pesquisas Físicas (CBPF) e a fundação de novos institutos, como o Instituto de Matemática Pura e Aplicada (IMPA) e o Instituto Nacional de Pesquisas da Amazônia (INPA), ambos em 1952, e do Instituto Brasileiro de Informação em Ciências e Tecnologia (IBICT) em $1954^{16}$.

Nessas universidades e institutos, os novos professores, diferentemente dos catedráticos tradicionais, mantinham, em paralelo à docência, pesquisas em laboratórios e convidavam os estudantes mais interessados dos cursos universitários a ingressar em seus grupos de pesquisa (NEVES, 2001). Ainda assim, durante os anos 1940 e 1950, o envolvimento dos estudantes de graduação na realização de pesquisas científicas ocorria de forma incipiente, sendo limitada à atividade de alunos ajudantes (BARIANI, 1998).

Nesse mesmo período, ocorreu a criação do Conselho Nacional de Desenvolvimento Científico e Tecnológico (CNPq), dando início ao financiamento da atividade de iniciação científica por meio da concessão de bolsas anuais já na graduação (MASSI e QUEIROZ, 2010). Foi também criada a Campanha Nacional de Aperfeiçoamento de Pessoal de Nível Superior (Capes) ${ }^{17}$, que teve como norte os ideais de Anísio Teixeira ${ }^{18}$ de melhoria das condições de ensino e pesquisa nos centros universitários

\footnotetext{
${ }^{16}$ Com exceção do INPA, todos esses institutos se localizam na cidade do Rio de Janeiro. ${ }^{17}$ Hoje chamada Coordenação de Aperfeiçoamento de Pessoal de Nível Superior.

${ }^{18}$ Anísio Teixeira (1900-1971) era jurista e educador. Foi um dos intelectuais signatários do Manifesto dos Pioneiros da Educação Nova, que defendia o ensino público, gratuito e laico.
} 
brasileiros. Para o educador, essas melhorias tinham como requisito básico a qualificação dos professores universitários, o que fez com que a Capes assumisse como prioridade o desenvolvimento dos programas de pósgraduação (GOUVÊA e MENDONÇA, 2006).

Portanto, a pós-graduação surge no Brasil em um contexto de melhora da formação de quadros de professores e pesquisadores das universidades. A iniciação científica se consolida, mais tarde, a partir da pós-graduação. Desta forma, no capítulo seguinte, discorro sobre o histórico da pós-graduação em nosso país e sobre o conhecimento produzido em relação à Iniciação Científica em uma perspectiva histórica, mas também educacional, considerando a IC como processo formativo. 


\section{3. Iniciação Científica - histórico e características}

Para compreender melhor os objetivos dos programas de iniciação científica, é fundamental conhecer a pós-graduação brasileira, pois a formação de cientistas acompanhou o desenvolvimento da configuração institucional da ciência no país. Como destacado no capítulo anterior, até o surgimento das universidades na década de 1920-30, a ciência era uma atividade secundária nos cursos superiores ou era feita de forma a resolver problemas práticos, realizada principalmente nos institutos criados no início do século XX. Entretanto, não havia uma grande preocupação com a formação de pesquisadores, e sim com a formação de profissionais liberais para a nova economia que se desenvolvia no país.

Foi apenas a partir da Reforma Universitária de 1968 (BRASIL, 1968) que os programas de pós-graduação passaram a ter papel central na produção científica e na formação de quadros de cientistas no país. A compreensão desse panorama é importante porque, no contexto da investigação aqui apresentada, parto da hipótese de que a IC se institucionaliza a partir do fortalecimento da pós-graduação, como uma estratégia de incentivo à formação de quadro de pesquisadores no Brasil. Para Martins (2009), a implantação da pós-graduação impulsionou "um vigoroso programa de iniciação científica, que tem contribuído para articular pesquisa e ensino de graduação e impulsionado a formação de novas gerações de pesquisadores" (MARTINS, 2009, p. 16-17).

\section{1.}

\section{A pós-graduação brasileira como instância de formação e produção do conhecimento}

A pós-graduação no Brasil é bem recente se compararmos com outros países. De acordo com Santos (2002), o texto da Reforma Francisco Campos (Decreto 19.851/31) já trazia referências à implantação de um doutorado na Universidade do Brasil, seguindo os moldes europeus. No 
mesmo ano (1931), foi implementado o curso de doutorado em Direito nessa mesma universidade, na qual, em 1939, foi fundada a Faculdade Nacional de Filosofia, com curso de doutorado seguindo os moldes propostos na Reforma, com um professor catedrático sendo responsável por orientar os alunos (SANTOS, 2002).

A partir da Reforma foram criados, pontualmente, novos cursos de pós-graduação. Entretanto, até a década de 1950, o teto da formação no Brasil ainda era majoritariamente a graduação, levando à busca por cursos de pós-graduação no exterior (SANTOS, 2002).

A demanda pela criação de novos cursos de pós-graduação e por uma melhor qualificação dos professores universitários brasileiros impulsionou a criação da Campanha Nacional de Aperfeiçoamento de Pessoal de Nível Superior (Capes) em 1951 (GOUVÊA e MENDONÇA, 2006).

Através de ações e boletins, a Capes iniciou o processo de criação de uma rede, de projetos e de bolsas referentes a cursos de pós-graduação. Os recursos direcionados para a criação e dinamização dos Centros Nacionais de Aperfeiçoamento Pós-graduado ${ }^{19}$ (CNAP) pela Capes foram consequência de um trabalho voltado para a consolidação $e$ institucionalização da pós-graduação no Brasil (GOUVÊA e MENDONÇA, 2006).

No mesmo período, destaca-se também a influência norte-americana na educação brasileira. Em 1952, foi firmado o primeiro acordo entre Brasil e Estados Unidos que implicava numa série de convênios entre escolas e faculdades norte-americanas e brasileiras. No início da década de 1960, com apoio da fundação Ford ${ }^{20}$, é criado o programa de Ciências Físicas e Biológicas na Universidade do Brasil, onde também é criada a Comissão Coordenadora dos Programas de Pós-Graduação em Engenharias

\footnotetext{
${ }^{19}$ Os Centros Nacionais de Aperfeiçoamento Pós-graduados (CNAP) foram instituídos no decreto no 29.741/51. Esses centros eram formados, nas universidades selecionadas, por um professor contratado e um grupo de cinco ou seis assistentes brasileiros, recrutados em diferentes instituições de ensino superior no país, devendo cada centro trabalhar com o mínimo possível de equipamento que lhe permitisse o treinamento dos próprios assistentes e o início dos trabalhos de pesquisa. Cada Centro seria, por outro lado, a origem do futuro instituto universitário dentro da área de sua especialidade. (GOUVÊA e MENDONÇA, 2006).

${ }^{20}$ A Fundação Ford é uma fundação estadunidense criada em 1934 que financia projetos ligados à promoção da democracia, desenvolvimento das ciências, artes e à redução da pobreza.
} 
(COPPE) (SANTOS, 2002). Esse já era um período pós Segunda Guerra Mundial, marcado pela consolidação do processo de industrialização iniciado na era Vargas e, assim, a formação de quadros de professores do magistério superior e de pesquisadores era fundamental para 0 desenvolvimento do país e para sua política externa (ROMÊO, ROMÊO e JORGE, 2004).

Durante o período militar a pós-graduação sofreu uma reorganização do ponto de vista legal ${ }^{21}$. O parecer $n^{0}$ 977/65 formalizou e apontou as principais diretrizes para a pós-graduação no país (GOUVÊA e MENDONÇA, 2006). Porém, a Reforma Universitária de 1968 (BRASIL, 1968) foi um passo importante para a organização legal da pós-graduação. Nesse documento, a pós-graduação assumia a responsabilidade de qualificar professores para o ensino superior, capacitar pessoal para atuar nos setores público e privado e estimular a produção de conhecimento científico vinculado ao desenvolvimento do país (ROMEO, ROMEO e JORGE, 2004). A Reforma modernizou parte das instituições federais, estaduais e confessionais de ensino. Criou-se condições propícias para a conexão entre atividades de ensino e pesquisa, até então bem desarticuladas (MARTINS, 2009).

Aboliram-se as cátedras vitalícias, introduziu-se o regime departamental, institucionalizou-se a carreira acadêmica, a legislação pertinente acoplou o ingresso e a progressão docente à titulação acadêmica. Para atender a esse dispositivo, criou-se uma política nacional de pós-graduação, expressa nos planos nacionais de pós-graduação e conduzida de forma eficiente pelas agências de fomento do governo federal. (MARTINS, 2009, p. 16).

As diretrizes do Parecer oㅡ 977/65, reforçadas na Reforma de 1968, delinearam uma estrutura de pós-graduação com inspirações nos modelos estadunidense e europeu. Para Santos (2002), o modelo de pós-graduação brasileiro é híbrido, pois foi adotada a estrutura dos cursos norteamericanos e a forma de avaliação dos programas europeus. Segundo o

\footnotetext{
${ }^{21}$ Para Gouvêa e Mendonça (2006), a pós-graduação já havia sido institucionalizada antes da regulamentação feita a partir do parecer ํํ 977/65 e da Reforma Universitária de 1968, com as ações desenvolvidas pela Capes determinante nesse processo. Para os autores, a institucionalização não pode ser confundida com a mera regulamentação de caráter legal, pois isso negaria a contribuição de muitos para a consolidação e institucionalização da pós-graduação no Brasil, em especial a atuação do educador Anísio Teixeira, primeiro Secretário Geral da Capes.
} 
autor, tal contexto fez com que nossos cursos de mestrado se configurassem de modo muito rígido, com níveis de exigência incompatíveis com o mesmo nível de formação de outros países, e quase semelhantes ao do doutorado. Santos (2002) considera que talvez essa rigidez tenha se dado em decorrência da falta de quadro de doutores no país no período de consolidação da pós-graduação.

A partir de 1973, foi criado o Conselho Nacional de Pós-graduação (CNPG), responsável pela formulação de uma política nacional de pósgraduação. Foi criado também o Grupo Técnico de Coordenação (GTC) que integrou as principais agências de financiamento: a CAPES, o CNPq, a Financiadora de Estudos e Projetos (Finep) e o Fundo Tecnológico (Funtec), sob a coordenação do Departamento de Assuntos Universitários do MEC (ROMEO, ROMEO e JORGE, 2004).

O CNPG ficou responsável pelo desenvolvimento e implantação dos Planos Nacionais de Pós-graduação (PNPG). Ao longo dos PNPG ${ }^{22}$ os objetivos da pós-graduação no país foram mudando. Inicialmente o foco era a qualificação dos docentes do ensino superior, mas gradativamente passou a ser a qualidade da pós-graduação, com uma tentativa de adequar os programas às "necessidades"23 do país, vinculando ensino e pesquisa com tecnologia e o setor produtivo. Através dos planos a pesquisa também passou a ser uma dimensão indissociável da pós-graduação (ROMEO, ROMEO e JORGE, 2004).

$\mathrm{Na}$ década de 1990, as políticas para a pós-graduação foram incipientes. A Lei de Diretrizes e Bases da Educação (LDB), lei n.ำ 9.394/96 (BRASIL, 1996), tem poucas rupturas com a visão de pós-graduação presente no Parecer nº 977/65. A pós-graduação consta na LDB/96²4 como parte do sistema de educação superior, reunido os programas de mestrado e doutorado, cursos de especialização e aperfeiçoamento e outros abertos a candidatos diplomados em cursos de graduação e que atendam às exigências dos estabelecimentos de ensino, ministrados em instituições de

\footnotetext{
${ }^{22}$ Foram implantados quatro PNPG, cada um com duração de cinco anos (o primeiro foi iniciado em 1974).

${ }^{23}$ Coloco o termo necessidade entre aspas, pois essas necessidades estavam vinculadas ao modelo econômico desenvolvimentista em vigor.

${ }^{24}$ Artigo 44, inciso III da n. 9 9.394/96.
} 
ensino superior públicas ou privadas, com variados graus de abrangência ou especialização. Uma novidade na década de 1990 seria a criação dos programas de mestrado e doutorado profissionalizantes que enfatizam estudos técnicos voltados para o desempenho profissional a partir da portaria no 80/98 da Capes (BRASIL. CAPES, 1998). Esses cursos diferem dos acadêmicos sobretudo no tipo de abordagem que se faz em relação ao tema pesquisado.

Para Gatti (2001), a implantação da pós-graduação e a Reforma Universitária de 1968 tiveram em seus escopos a modernização do ensino superior nos quadros do projeto de desenvolvimento econômico adotado. A autora ressalta que

os cursos de pós-graduação - mestrados e doutorados - foram criados, apoiados e sustentados em seu desenvolvimento sob um certo modelo e vocação não discutidos amplamente, mas gestados por setores da burocracia estatal em consenso com algumas lideranças acadêmicas, e, por isto mesmo, um modelo voltado ao desenvolvimentismo e à formação de quadros para a pesquisa e para as universidades, dentro de uma certa concepção sobre ciência, sobre seu papel e os das tecnologias e sua produção/reprodução. (GATI, 2001, p. 108-109).

Assim, Gatti (2001) considera que os cursos de mestrado e doutorado brasileiros inicialmente não são desdobramentos da produção científica das universidades nas décadas de 1950 e 1960, já que, à época, formavam basicamente profissionais liberais.

Ao longo das duas décadas de vigência dos PNPG, a pós-graduação foi perdendo seu papel de qualificação dos professores universitários e assumindo um protagonismo como espaço para a pesquisa. Os planos também contribuíram para a institucionalização das bolsas de auxílio e para a ampliação da dimensão da avaliação, a partir da criação de comissões avaliadoras com participação de pares da comunidade científica.

\section{2.}

\section{A Iniciação Científica}

A formação de novos pesquisadores ocorre sempre que um novato aprende sobre o fazer científico com um mestre mais experiente. Nesse sentido, o novato é iniciado nos ritos, técnicas e tradições das comunidades científicas. O objetivo desta seção, entretanto, é apresentar a iniciação científica (IC) como uma política para o incentivo de formação de novos 
pesquisadores implementada de forma institucionalizada no Brasil. A IC no país tem sua origem atrelada à concessão de bolsas a partir da criação de agências de fomento, como o CNPq. De acordo com Massi e Queiroz (2010), o financiamento das atividades de IC foi respaldado pela Lei da Reforma Universitária de 1968, momento em que se determinou o princípio da "indissociabilidade entre ensino-pesquisa"25 (BRASIL, 1968). Assim, a IC nasce como uma possibilidade de vincular a pesquisa ao ensino.

Pode-se considerar os anos 1970 e 1980 como o período de "instalação e fortalecimento da pesquisa e da pós-graduação", e os anos 1990 como o período em que houve um crescimento significativo no número de bolsas, como a fase da "valorização" da IC. Assim, a década de 1990 é o período onde ocorreu o crescimento e consolidação dos programas de IC no país. Os dados relativos ao número de bolsas de IC concedidas pelo CNPq demonstram um aumento acentuado na quantidade de bolsas distribuídas de 1963 a 2005. Atualmente, o número de bolsas de IC é superior ao número de bolsas de outros tipos concedidas pelo CNPq, o que reforça a importância dada à atividade de IC pelo órgão (MASSI e QUEIROZ, 2015).

O Programa Institucional de Bolsas de Iniciação Científica (PIBIC) foi criado em 1988 e pode-se dizer que representa o marco na institucionalização da IC. Antes da criação do PIBIC o CNPq distribuía as bolsas de IC a partir da solicitação direta do pesquisador. Essas bolsas são conhecidas como "bolsas por demanda espontânea" ou "bolsa balcão". O CNPq ainda mantém esta modalidade de bolsas, mas dados de 2012 mostram que o número de bolsas PIBIC é seis vezes maior (MASSI e QUEIROZ, 2015).

Algumas iniciativas como o Programa de Vocação Científica da Fundação Oswaldo Cruz (Provoc/Fiocruz), criado em 1986, são anteriores à criação do PIBIC. No Provoc, alunos do ensino médio de escolas conveniadas participavam das atividades de pesquisa do laboratório ${ }^{26}$. Entretanto, mesmo considerando a importância desse programa para o

\footnotetext{
${ }^{25}$ Artigo 20 da lei no 5540/68 (BRASIL, 1968).

${ }^{26}$ As características e o histórico do Provoc serão aprofundados mais à frente na seção relacionada à Iniciação Científica no ensino médio.
} 
desenvolvimento de práticas e conhecimento sobre a IC, cabe ponderar que o Provoc é restrito a alunos de ensino médio de algumas escolas do Rio de Janeiro.

É a partir da criação do PIBIC que a IC passa a ser uma política nacional para a iniciação de alunos dos cursos de graduação nas atividades de pesquisa. O que muda com o PIBIC é que as bolsas de IC passaram a ser concedidas diretamente às instituições de ensino superior e aos institutos de pesquisa, que assumiram também a gestão da concessão de bolsas, criando mecanismos administrativos próprios. O PIBIC tem como objetivos:

proporcionar ao bolsista, orientado por pesquisador qualificado, a aprendizagem de técnicas e métodos de pesquisa, bem como estimular o desenvolvimento do pensar cientificamente e da criatividade, decorrentes das condições criadas pelo confronto direto com os problemas de pesquisa; e ampliar o acesso e a integração do estudante à cultura científica." ${ }^{27}$

Os demais objetivos do programa também estão centrados na lógica de "despertar a vocação científica de jovens" e selecionar "novos talentos entre os estudantes de graduação". É um programa que pretende incentivar a formação de recursos humanos para a pesquisa e, mais do que isso, reduzir o tempo na formação de pesquisadores, acelerando a formação de mestres e doutores, bem como proporcionar uma maior integração entre os cursos de graduação e pós-graduação (BRASIL. CNPq, 2006).

Assim, esse modelo de IC é uma política característica de nosso país, advinda da necessidade de se formar pesquisadores em intervalo de tempo mais curto. É importante destacar que, no âmbito internacional, existem diferentes modalidades de IC, incluindo programas voltados para o ensino médio. Mas esse modelo de IC institucionalizado não ocorre em outros países, onde o envolvimento dos alunos de graduação em atividades de pesquisa depende mais de iniciativas individuais dos professores (MASSI e QUEIROZ, 2015).

Nas diretrizes do PIBIC, cabe à cada instituição estabelecer as regras de seleção dos alunos bolsistas, que devem ser amplamente divulgadas, juntamente com as datas do processo seletivo em edital

\footnotetext{
${ }^{27}$ As informações sobre os objetivos do PIBIC estão disponíveis em <http://cnpq.br/pibic>. Acesso em: 02 fev. 2017.
} 
público. A instituição deverá ter um Coordenador Institucional de Iniciação Científica, bem como um comitê interno para gerenciar o Programa dentro das normas estabelecidas pelo CNPq. Também é preciso que anualmente seja convocado um comitê externo que participe do processo de seleção e avaliação do Programa. Cada instituição poderá definir critérios de acompanhamento e avaliação, sendo que para a avaliação a Instituição deverá:

a) realizar anualmente uma reunião, na forma de seminário ou congresso, onde os bolsistas deverão apresentar sua produção científica sob a forma de pôsteres, resumos e/ou apresentações orais. O desempenho do bolsista deverá ser avaliado pelo Comitê Institucional do PIBIC com base nos produtos apresentados nesta reunião e por critérios da própria instituição;

b) publicar os resumos dos trabalhos dos bolsistas que serão apresentados durante o processo de avaliação, em livro, cd ou na página da instituição na Internet;

c) convidar o Comitê Externo para atuar na avaliação do Programa, durante o seminário. (BRASIL. CNPq, 2006).

De acordo com Damasceno (2002), o PIBIC se desenvolve principalmente nas universidades públicas, sendo quase a totalidade de oferta de bolsas ao setor privado representado pelas Pontifícias Universidades Católicas (PUC). A autora destaca que a inserção das Pontifícias no programa se deve à qualidade do ensino nessas instituições, bem como o desenvolvimento de pesquisa, o que não é encontrado na maior parte da rede de educação superior privada.

Damasceno (2002) também usa dados do CNPq para afirmar que aproximadamente $50 \%$ das bolsas estão concentradas na região sudeste, atribuindo tal cenário ao fato da região reunir a maior parte das instituições de pesquisa do país. A autora se baseia em relatórios do CNPq do final da década de 1990, mas, de acordo com a análise de Massi e Queiroz (2015) do relatório de 2009, essa desigualdade regional se mantém. Os autores também destacam que é importante ponderar que a maioria dos estudantes do ensino superior brasileiro encontra-se matriculada no setor privado, onde, como já dito, em geral, não se realiza a pesquisa. Este fato, associado a essa desigualdade regional na distribuição de bolsas, leva ao questionamento dessa abrangência nacional do PIBIC. 
É importante ressaltar aqui que, do ponto de vista formativo, a iniciação científica não é feita apenas quando o aluno possui uma bolsa, ou especificamente uma bolsa PIBIC. Para Massi e Queiroz (2015), a IC no ensino superior pode ser entendida sob duas perspectivas. Em uma, essa modalidade seria um processo que envolveria todas as experiências vivenciadas pelo aluno durante a graduação com o objetivo de promover seu envolvimento com a pesquisa. Incluiria, portanto, programas de treinamento, estudos sobre metodologia científica, visitas a institutos de pesquisa, e poderia acontecer dentro de uma disciplina ou não. Na outra perspectiva, o aluno desenvolve um projeto de pesquisa elaborado e realizado sob a supervisão de um docente, que pode acontecer com ou sem uma bolsa de auxílio. Assim como as autoras, para a realização desta pesquisa, utilizo a segunda perspectiva.

Embora a bolsa não seja determinante para que o aluno desenvolva uma atividade de IC, a institucionalização e incentivo decorrente da criação do PIBIC parecem influenciar algumas diretrizes usadas pelos professores nesse processo formativo, como o estabelecimento de critérios para seleção dos alunos, o desenvolvimento de uma pesquisa e a apresentação dos resultados, seja em um seminário interno da instituição ou em um evento científico, a partir da elaboração de um relatório ou artigo.

Entretanto, Massi e Queiroz (2010) afirmam que apesar da existência de diretrizes para a realização das atividades de IC, estabelecidas pelos órgãos de fomento e pelas Instituições de Ensino Superior (IES) e Institutos de Pesquisa (IPq), as investigações realizadas sobre a temática mostram que 0 desenvolvimento do trabalho é determinado principalmente, ou quase exclusivamente, pelo orientador, o que leva a diferentes formas de condução da pesquisa com relação ao tipo de atividade desenvolvida e à seleção dos bolsistas. Além disso, existiria uma concentração dos alunos de IC em atividades como revisão bibliográfica, coleta e tabulação de dados e que poucos participariam da elaboração do referencial teórico e dos processos de sistematização e avaliação da pesquisa. 
Outra dimensão importante, destacada na revisão realizada por Massi e Queiroz (2010) sobre pesquisas relacionadas às atividades de IC, é que o aluno pode ter um projeto de pesquisa individual ou pode ser integrado a um projeto em andamento (em geral o bolsista é integrado e depois pode vir a ter seu projeto individual) e que a sua orientação em geral é compartilhada com os outros membros do laboratório ou grupo de pesquisa, em especial, com os alunos de pós-graduação.

O trabalho de revisão bibliográfica desenvolvido pelas autoras coincide com levantamento bibliográfico realizado nesta pesquisa, no sentido de demonstrar que, apesar de sua relevância, considerando a importância da IC na formação inicial de pesquisadores, e do número crescente de bolsas desse tipo concedidas pelos órgãos de fomento, há poucas pesquisas sobre esse tipo de processo formativo. Com relação aos recursos metodológicos, a maioria das pesquisas sobre a IC, em geral teses e dissertações, foram desenvolvidas com dados levantados a partir de questionários e entrevistas com alunos ou orientadores de cursos de graduação. Cabe destacar que não há nenhum trabalho sobre a iniciação científica em museus.

Para Massi e Queiroz (2015), as pesquisas sobre a IC podem ser divididas em 3 grupos:

I) As que avaliam as atividades de iniciação científica na formação do aluno.

II) As que avaliam o PIBIC em relação a seus objetivos.

III) As que caracterizam as particularidades no desenvolvimento da IC.

É possível afirmar que a pesquisa aqui apresentada se insere no terceiro grupo, na medida em que procuro entender os aspectos da IC realizada em museus, como os processos de seleção, natureza das atividades desenvolvidas, particularidades, processos formativos e avaliativos. 


\section{3.}

\section{A Iniciação Científica no ensino médio}

A iniciação científica no ensino médio (IC-EM), também chamada de iniciação científica júnior (IC-Jr.), é uma modalidade de iniciação científica que normalmente se desenvolve quando alunos do ensino médio têm a oportunidade de vivenciar a rotina de uma pesquisa, desenvolvida em diferentes setores de uma universidade ou centro de pesquisa. A IC-Jr. é semelhante à iniciação científica realizada por alunos da graduação, na medida em que o aluno é introduzido a atividades sistematizadas de um grupo de pesquisa, mas difere daquela desenvolvida na graduação, pois o aluno de ensino médio a priori ainda não fez sua escolha profissional.

Os programas de IC em geral (com alunos na graduação ou no ensino médio) trazem como objetivo: o diálogo entre ensino e pesquisa, o despertar de "vocações científicas" e a possibilidade do aluno vivenciar o cotidiano de um ambiente de pesquisa. Entretanto, como já discutido, um outro viés que se tornou forte a partir da década de 1980 foi a necessidade de se acelerar a formação de cientistas no país com a redução do tempo médio de permanência do aluno na pós-graduação.

E é nesse contexto que é criado em 1986 o Programa de vocação científica (Provoc) da Fundação Oswaldo Cruz (RJ). De acordo com Neves (2001), "o Provoc nasce da intenção do pesquisador Luiz Fernando Ferreira ${ }^{28}$ iniciar jovens na Ciência precocemente" (NEVES, 2001, p. 73).

Em uma escala nacional, a IC-Jr. é institucionalizada com a criação de bolsas PIBIC-EM, que de acordo com o CNPq tem como objetivo29 "(1) Fortalecer o processo de disseminação das informações e conhecimentos científicos e tecnológicos básicos e (2) desenvolver atitudes, habilidades e valores necessários à educação científica e tecnológica dos estudantes".

O CNPq conta também com o Programa de Iniciação Científica Júnior (ICJ), que tem como objetivo o desenvolvimento de projetos

28 Luiz Fernando da Rocha Ferreira da Silva é médico, professor e pesquisador emérito da Fiocruz, internacionalmente reconhecido por sua pesquisa na área de paleoparasitologia.

${ }^{29}$ Os objetivos dos programas de iniciação científica desenvolvidos pelo CNPq foram retirados do site oficial desta agência na seção "bolsas e auxílios". < http://cnpq.br/\#void>. Acesso em: 02 set. 2017. 
científicos com estudantes do ensino fundamental, médio e técnico por meio de concessão de cotas a entidades estaduais de fomento à pesquisa.

Os objetivos do ICJ são: (1) Despertar vocação científica e incentivar talentos potenciais entre estudantes do ensino fundamental, médio e profissional da Rede Pública, e (2) possibilitar a participação de alunos do ensino médio em atividades de pesquisa científica ou tecnológica, orientada por pesquisador qualificado, em instituições de ensino superior ou institutos/centros de pesquisas. Os objetivos entre os dois programas são semelhantes, diferindo apenas na esfera de atuação (no PIBIC-EM as cotas são concedidas às IFE e IPE e no ICJ às agências estaduais).

Atualmente há também o Programa de Iniciação Científica das Olimpíadas Brasileiras de Matemática das Escolas Públicas (PIC-OBMEP). O PIC-OBMEP tem como objetivos: (1) Fortalecer o ensino de matemática nas Escolas Públicas; (2) despertar nos alunos o gosto pela matemática e pela ciência em geral; (3) motivar os alunos na escolha profissional pelas carreiras científicas e tecnológicas, e (4) contribuir para a formação matemática dos estudantes premiados da OBMEP. As instituições participantes devem desenvolver pesquisa na área de matemática ou áreas afins. Para obter a bolsa, o estudante precisa ter sido premiado na OBMEP e ser estudante da rede pública.

Além dos programas nacionais promovidos pelo CNPq, existem programas para promoção da IC-EM em escala regional no Estado do Rio de Janeiro: o já citado Programa de vocação científica (Provoc) coordenado pela Escola Politécnica Joaquim Venâncio (EPJV/Fiocruz); o Programa de IC-Jr. do Colégio Pedro II (PIC-Jr./CPII) e o Programa Jovens Talentos para a Ciência (PJTC) coordenados pela Secretaria de Estado de Ciência e Tecnologia, por meio da fundação CECIERJ.

Como dito, o Programa PIBIC-EM do CNPq na esfera estadual é organizado dentro de cada universidade ou Instituto de Pesquisa, assim como acontece com o PIBIC para os alunos de graduação. No CAp/UFRJ há um Núcleo de Iniciação Científica Júnior (NIC-Jr.) que acompanha os alunos de ensino médio bolsistas do Provoc e do PIBIC-EM da UFRJ. Os alunos do CAp participam de atividades de IC em parceria com outras 
instituições desde 1990, mas em 2001, devido ao crescimento e complexidade desse tipo de formação, o colégio criou um núcleo específico para essas atividades, com a intenção de organizar as ações, ampliar a participação de instituições, pesquisadores e alunos, facilitar a obtenção de recursos e dar visibilidade às atividades desenvolvidas.

Os objetivos do NIC-Jr. são: (1) incentivar o aluno para a atividade de pesquisa; (2) contribuir na definição de sua escolha profissional; (3) antecipar o contato do estudante com o ambiente acadêmico, possibilitando-Ihe uma aprendizagem de metodologia de pesquisa, de trabalho em equipe e de divulgação de resultados científicos; (4) ampliar a articulação entre Educação Básica e Educação Superior / Centros de Pesquisa.

Os programas de IC-EM do Estado do Rio de Janeiro se desenvolvem de maneira independente quanto aos processos de seleção e origem das bolsas concedidas aos alunos e serão melhor detalhados na seção a seguir.

\subsection{1.}

\section{Os Programas de IC-EM no Estado do Rio de Janeiro}

Bessa (2015) traçou o perfil desses programas a partir das informações contidas nos sites institucionais. De acordo com a pesquisa, 37 unidades e centros de pesquisa de diferentes Universidades e instituições do Estado estão vinculados a esses programas para receberem estagiários de $\mathrm{IC} \mathrm{EM}^{30}$. A maioria das unidades localiza-se na região metropolitana do estado com 21 unidades, das quais 14 situam-se na capital e as demais em outros 5 municípios, enquanto as demais regiões exibem um número menor de unidades vinculadas. Os públicos-alvo e objetivos de cada programa estão indicados no Quadro 1.

É possível perceber que, embora cada programa trace seus objetivos, todos evocam a questão do despertar da "vocação científica", da escolha profissional e da possibilidade da vivência profissional do fazer científico

\footnotetext{
30 Levantamento realizado até 2012, havendo instituições que estão simultaneamente
} ligadas a mais de um programa. 
Quadro 1: Dados dos Programas de IC-EM do Estado do Rio de Janeiro

\begin{tabular}{|c|c|c|c|c|}
\hline Programa & $\begin{array}{l}\text { Instituição } \\
\text { Promotora }\end{array}$ & $\begin{array}{l}\text { Ano de } \\
\text { Criação }\end{array}$ & Público Atendido & Objetivos \\
\hline Provoc & Fiocruz & 1986 & $\begin{array}{l}\text { Alunos da } 1^{\text {a }} \text { série do } \\
\text { EM de escolas } \\
\text { conveniadas e de } \\
\text { projetos sociais do } \\
\text { Complexo da Maré e } \\
\text { Manguinho. } \\
\text { Alunos da } 2^{a} \text { série do } \\
\text { EM em caso de } \\
\text { estágio avançado. }\end{array}$ & $\begin{array}{l}\text { (1) Proporcionar ao aluno do ensino médio, orientado por pesquisador qualificado, a } \\
\text { aprendizagem de métodos e técnicas de pesquisa relevantes para a sua formação científica e } \\
\text { tecnológica, bem como estimular o desenvolvimento do pensamento crítico e da criatividade com } \\
\text { base nos princípios gerais de autonomia do educando; (2) Incentivar pesquisadores qualificados } \\
\text { e suas equipes a envolverem alunos do ensino médio nas atividades científicas, tecnológicas, } \\
\text { profissionais, artísticas e culturais da Fiocruz; (3) Contribuir para a melhoria da qualidade do } \\
\text { ensino de ciências - da natureza e matemática, humanas e sociais - e suas tecnologias nas } \\
\text { escolas de nível médio, com ênfase nos dois princípios pedagógicos que integram a formação } \\
\text { geral do educando, a saber: interdisciplinaridade e contextualização do conhecimento produzido } \\
\text { pelos diferentes grupos sociais (Resolução CNE/CEB no 03/98, que estabelece as Diretrizes } \\
\text { Curriculares Nacionais para o Ensino Médio); (4) Propiciar ao aluno do ensino médio que } \\
\text { participa do Provoc conhecimentos sobre as profissões e as carreiras voltadas para as áreas de } \\
\text { pesquisa científica, desenvolvimento tecnológico e gestão e inovação em C\&T. }\end{array}$ \\
\hline PIBIC-EM & UFRJ & 1990 & $\begin{array}{l}\text { Alunos da } 1^{\text {a }} \text { série do } \\
\text { EM de escolas } \\
\text { conveniadas. } \\
\text { Alunos da } 2^{\underline{a}} \text { série do } \\
\text { EM em caso de } \\
\text { estágio avançado. }\end{array}$ & $\begin{array}{l}\text { (1) incentivar o aluno para a atividade de pesquisa; (2) contribuir na definição de sua escolha } \\
\text { profissional; (3) antecipar o contato do estudante com o ambiente acadêmico, possibilitando-lhe } \\
\text { uma aprendizagem de metodologia de pesquisa, de trabalho em equipe e de divulgação de } \\
\text { resultados científicos; (4) ampliar a articulação entre Educação Básica e Educação Superior / } \\
\text { Centros de Pesquisa. }\end{array}$ \\
\hline $\begin{array}{l}\text { PIC-Jr. do } \\
\text { Colégio } \\
\text { Pedro II }\end{array}$ & $\begin{array}{l}\text { Colégio Pedro } \\
\text { II e Museu } \\
\text { Naciona/UFRJ }\end{array}$ & 1999 & $\begin{array}{l}\text { Alunos da } 1^{\text {a }} \text { série do } \\
\text { EM do Colégio Pedro } \\
\text { II. } \\
\text { Alunos da } 2^{\underline{a}} \text { série do } \\
\text { EM em caso de } \\
\text { estágio avançado. }\end{array}$ & $\begin{array}{l}\text { (1) possibilitar a vivência dos estudantes em diversas práticas de pesquisa científica em } \\
\text { diferentes campos do conhecimento; (2) despertar o interesse pela organização e preservação } \\
\text { do acervo institucional, e pelo desenvolvimento de atividades educativas e culturais; (3) permitir a } \\
\text { vivência teórico prática de estudantes com a vida profissional e contribuir para uma escolha mais } \\
\text { consciente de sua futura carreira, bem como preparar para o mundo do trabalho; (4) desenvolver } \\
\text { no ensino médio novas experiências no processo de ensino-aprendizagem, contribuindo para a } \\
\text { formação acadêmica dos alunos. }\end{array}$ \\
\hline PJTC & FAPERJ & 1999 & $\begin{array}{l}\text { Alunos entre } 15 \text { e } 18 \\
\text { anos da rede } \\
\text { estadual de ensino. } \\
\text { Estágio Avançado. }\end{array}$ & $\begin{array}{l}\text { (1) Os Selecionar estudantes com grande interesse pela ciência e potencial para atuar em } \\
\text { pesquisa científica; (2) Estimular a formação dos estudantes criando possibilidade de identificar } \\
\text { novos quadros para atuação profissional no campo do saber científico; (3) Contribuir para a } \\
\text { difusão dos conhecimentos científicos, desmitificando a ciência e articulando pesquisa e ensino }\end{array}$ \\
\hline
\end{tabular}

Fonte: Bessa (2015) 
que estão nas diretrizes das bolsas nacionais de IC-EM e IC-Jr. cedidas pelo CNPq.

Em relação aos objetivos específicos de cada programa, apenas o NIC-Jr. do CAp/UFRJ reforça a diretriz nacional de antecipação da formação do cientista via IC. É interessante notar que esses programas vão além das diretrizes do CNPq quando apontam que a IC-EM é uma possibilidade de melhoria do ensino de ciências (Provoc), uma possibilidade de articulação entre educação básica e o ensino superior (PIBIC/UFRJ) e uma possibilidade de novas experiências de ensino e aprendizagem no ensino médio (PIC Jr./Pedro II). O PJTC/FAPERJ retoma a questão da articulação entre ensino e pesquisa que está nas origens da implantação da IC na década de 1950.

É preciso considerar que a IC feita com alunos de ensino médio tem, ou deveria ter, objetivos específicos e certas especificidades nas atividades desenvolvidas. Filipecki e colaboradores (2006) também consideram que

a iniciação científica de estudantes de ensino médio, no Brasil, ainda é uma experiência nova. Portanto, seus objetivos estão sendo redefinidos constantemente. Além disso, não existe, na literatura, um número significativo de estudos que permita estabelecer a priori os referenciais a serem adotados (FILIPECKI, BARROS e ELIA, 2006, p. 200).

Considerando que esse trabalho já possui mais uma década, e que a criação do Provoc completou 30 anos, já não é possível dizer que essas iniciativas são tão recentes, mas, da mesma forma, há pouca reflexão sobre a IC-EM, com exceção do próprio Provoc que é estudado pelo Laboratório de Iniciação Científica na Educação Básica (LIC-Provoc), com várias publicações sobre o trabalho desenvolvido neste programa.

Como destacado anteriormente, se olharmos os objetivos desses programas de IC no ensino médio, por um lado eles simplesmente reproduzem os mesmos objetivos da IC que é realizada na graduação. Entretanto, é possível constatar que, dos quatro programas do estado, três trazem em seus objetivos questões relacionadas à educação básica. $O$ PIC-Jr. do Colégio Pedro II tem em seus objetivos a possibilidade de oferecer novas experiências para o ensino médio. O Provoc destaca a melhoria do ensino de Ciências. Já o PIBIC traz a possibilidade de articulação entre a educação básica e o ensino superior. 
É interessante destacar também que o Projeto de Lei no 6840 de 2013 evoca, em sua justificativa, a criação de programas de bolsas de ICEM como forma de motivar os "alunos do ensino médio a permanecerem na escola, especialmente aqueles que necessitam trabalhar" (BRASIL. CEENSI, 2013, p. 13). O projeto considera que a concessão de bolsas de IC poderia adiar a entrada do aluno no mercado de trabalho e contribuir para a conclusão dos estudos desse sujeito.

Aqui é importante contextualizar que o Projeto de Lei $(\mathrm{PL})$ citado era uma proposta de uma Comissão Especial destinada a promover Estudos e Proposições para a Reformulação do Ensino Médio (CEENSI). A comissão foi criada com a intenção de apontar caminhos para a reformulação desse segmento devido ao resultado negativo de índices, como o declínio no número de matrículas, baixo rendimento dos alunos nos exames de avaliação nacionais e internacionais e altos índices de evasão e de distorção idade/série. O PL é o principal produto dessa comissão e encontrava-se em fase de apreciação do Plenário até a publicação da Medida Provisória no 746/2016 conhecida como MP do ensino médio, atual Lei no 13415/17 (BRASIL. Presidência da República, 2017). O texto da nova lei não traz nenhuma referência à iniciação científica no ensino médio.

Se pensarmos na temática da IC-EM, sob o ponto de vista das políticas públicas para o ensino médio, faz-se necessário considerar uma questão nem sempre óbvia para professores universitários e pesquisadores que orientam o público desses programas: "a de que fazer iniciação científica com alunos e alunas do ensino médio não é o mesmo que realizála com estudantes de graduação" (FERREIRA, 2010, p. 232). Para a autora, é importante considerar o fato dos alunos da graduação, diferentemente dos alunos do ensino médio, já fizeram uma escolha profissional. Nesse contexto, cabe questionar como laboratórios e grupos de pesquisa lidam com esses alunos, em que medida reconhecem as especificidades desse grau de escolarização e como a inserção desses estudantes nos grupos de pesquisa tem contribuído para fomentar o debate acerca da educação em ciências nos diferentes níveis. 
A autora segue questionando sobre que noções de ciências têm sido ensinadas na iniciação científica voltada para alunos de ensino médio e se esse processo de IC tem fomentado uma reflexão crítica sobre os conhecimentos científicos e sobre o trabalho dos cientistas. Ainda dentro dessa reflexão, Latour e Woolgar (1997) propõem que a ciência não se distingue de outras práticas sociais. O cientista, como qualquer outro ator social, é alguém que utiliza estratégias persuasivas que visam garantir aceitação dos enunciados por ele produzidos. Entretanto, Filipeck e colaboradores (2006) ressaltam que os programas de IC-EM, embora diversos, são balizados pela crença de que a relação pesquisadororientando contribui para o desenvolvimento pessoal e profissional do jovem. Aqui cabe uma reflexão sobre uma visão positivista sobre a ciência como promotora exclusivamente do que é "bom" ou do "bem".

Ao analisar o Provoc, Filipeck e colaboradores (2006) consideram que seria importante avaliar em que medida os objetivos relacionados ao pensamento científico, como integrar teoria e prática, solucionar problemas, sistematizar procedimentos no laboratório, visões de ciências aprendidas, são alcançados pelos estudantes. Entendo que esse tipo de análise e reflexão seria fundamental para a formação em todos os programas mencionados, mesmo para os de graduação. Entretanto, uma formação que contemple essas dimensões não faz parte dos objetivos dos programas aqui avaliados, que parecem focar no aspecto da vocação e da aceleração da formação da mão de obra de pesquisadores.

Sobre a relação universidade-escola que, em tese, seria fomentada nos programa de IC-EM, é interessante notar que há pesquisas que mostram que muitos orientadores sentem falta do diálogo com a escola. No trabalho de Filipeck e colaboradores (2006), os orientadores entendem a escola também como um possível espaço para a Iniciação Científica e não apenas o espaço de laboratório. No trabalho de Martins (2003), que avaliou a IC-EM de alunos do CAp-UFRJ, é verificado nas falas dos orientadores uma necessidade de diálogo com a escola para uma adequação didática do trabalho e, no depoimento de alguns alunos, uma preferência por atividades de IC desenvolvidas na própria escola. Entretanto, essa visão 
de IC estaria mais relacionada à primeira perspectiva apontada por Massi e Queiroz (2015) de que a iniciação científica seria qualquer experiência em que o aluno vivenciasse as etapas do fazer científico, não necessariamente desenvolvendo uma pesquisa.

Matos e colaboradoras (2012) defendem que a orientação de bolsistas de IC-EM em uma interlocução mais estreita com a escola básica se mostra promissora, pois permite perceber as especificidades dos bolsistas no que se refere à linguagem e aos conhecimentos prévios, escolares ou não, trazidos por alunos que ainda não fizeram uma escolha acerca do seu futuro profissional. Já Bessa (2015) defende a realização da IC a partir de parcerias entre um pesquisador e um professor da escola básica, como forma de ampliar o alcance dos alunos a esse tipo de programa, uma vez que os centros de pesquisa se concentram na região metropolitana do estado e possuem um número de vagas reduzidas. Aqui cabe lembrar sobre a necessidade de se analisar também de que forma se dá a seleção dos alunos para esses programas.

A relação universidade-escola criada intencionalmente, ou ao menos indiretamente, por esses programas de IC-EM parece ser ignorada por seus atores, ou não é investigada por parte dos pesquisadores que se debruçam sobre o tema. É preciso considerar aqui que o aluno de ensino médio transita entre esses dois espaços, o que ao menos cria uma relação indireta entre eles. 


\section{4. \\ Museus - espaços para a produção do conhecimento e educação}

Como discutido no capítulo 2, foi nas universidades alemãs, no século XIX, que a pesquisa começou a ser associada ao ensino e à formação de novos pesquisadores. Mas, antes disso, já havia a produção de conhecimento científico, seja nas Sociedades Científicas, ou em outras instituições como nos museus e jardins botânicos. ${ }^{31}$

No Brasil, a criação das Sociedades Científicas, museus e cursos superiores só aconteceu no século XIX, após a chegada da família real e, como discutido anteriormente, as primeiras universidades surgiram apenas na primeira metade do século XX. Para Schwartzman (2015), as primeiras tradições de trabalho de pesquisa científica só surgiram após a criação dos cursos superiores (Ciências Biológicas a partir dos cursos de Medicina, e Física, dos cursos de Engenharia). A formação de pesquisadores só passa a se dar de forma organizada e institucionalizada após a criação das universidades.

Entretanto, a investigação realizada por Lopes (2009) aponta que a pesquisa científica desenvolvida no Brasil no século XIX é, em geral, pouco considerada na historiografia oficial, incluindo a produção feita nos museus brasileiros, em especial o Museu Nacional ${ }^{32}$. A autora contesta essa visão de que a produção de ciência no século XIX restringia-se a atividades que antecederam a produção da ciência moderna. Visão historiográfica para a qual a implantação de uma ciência moderna, no Brasil, só viria a acontecer no século XX com a organização dos institutos de pesquisa e das universidades.

\footnotetext{
${ }^{31}$ A partir da definição de museus do ICOM, pode-se considerar que os Jardins Botânicos também são museus.

32 O Museu Nacional foi a primeira instituição museal criada no Brasil. Foi fundado em 1818 na cidade do Rio de Janeiro com o nome de Museu Real, sendo integrado a UFRJ em 1946.
} 
Para a autora, a partir de uma nova epistemologia da ciência, que reconhece que as ideias, as instituições e as estruturas das relações sociais no âmbito científico são construções humanas, "socialmente contingentes, sem nenhum caráter de eternidade, tendo sido criadas, pensadas ou "descobertas" 33 por pessoas particulares, em momentos particulares" (LOPES, 2009, p. 19), pode-se questionar os modelos eurocêntricos e difusicionistas da ciência ocidental europeia. Nessa nova perspectiva de análise, estudos têm sido realizados numa tentativa de entender melhor os processos de disseminação, incorporação e desenvolvimento da ciência nos países não europeus. Para Lopes (2009), mesmo no âmbito desses novos estudos, o papel dos museus no processo de institucionalização das ciências naturais no século XIX é até hoje pouco explorado.

Em diálogo com a autora, entendo que, para que seja possível compreender como a produção de conhecimento ocorre nos museus, é importante conhecer a história dessas instituições. Refletindo sobre a construção do caráter público dos museus, Valente (2003) faz o exercício de traçar as mudanças que levaram esses espaços a terem hoje, entre suas principais funções, a educação e a pesquisa. Faço então uma breve apresentação do histórico dos museus baseada nos textos de Valente (2003) e de Poulot (2013).

Embora o termo museu já fosse usado desde a antiguidade, como, por exemplo, no museu de Alexandria, foi a partir do século XV que esse termo passou a ser utilizado com frequência na Europa. O museu de Alexandria tinha um papel de guarda da coleção, mas era principalmente um local de ensino e pesquisa, sendo bastante conhecido por sua famosa biblioteca. Na Europa do século XV, entretanto, os museus tinham essencialmente sua função relacionada à formação de coleções religiosas.

Com o renascimento cultural e o rompimento com uma visão de mundo essencialmente religiosa, a aristocracia começa a investir em coleções, que passam, portanto, a se tornar símbolos de status nos séculos seguintes.

\footnotetext{
${ }^{33}$ Aspas da autora.
} 
Nos séculos $\mathrm{XVI}$ e XVII, artistas, sábios e eruditos iniciam uma pressão para o acesso e estudo dessas coleções, representando o início de um processo de abertura das coleções, mesmo que ainda para um público restrito. Em paralelo a esse movimento, o fortalecimento dos ideais burgueses e da identidade nacional, decorrentes da Revolução Francesa, no final do século XVIII, contribuiu para uma mudança na compreensão sobre patrimônio cultural. As coleções passaram a ser gradualmente abertas ao público, de forma organizada, para a formação do gosto e espírito de nação. Nesse momento inicia-se a consolidação do caráter público e educativo dos museus.

Os objetos coletados pelos impérios coloniais e as coleções etnográficas acumuladas em viagens exploratórias levou, no século XIX e até $O$ início do século $X X$, a uma apresentação de objetos associados a uma concepção evolucionista das culturas. Nesse período são criados grandes museus focados na pesquisa etnográfica e na divulgação das ciências naturais, como o Museu Nacional do Rio de Janeiro. Entretanto, já no final do século XIX, há uma mudança na forma de se expor as coleções, que deixa de seguir as classificações sistemáticas e passam a ser expostas de forma temática e com caráter didático. Esse é um importante passo para a democratização dos museus ao grande público. Segundo Valente (2003, p. 39), "os museus chegam às primeiras décadas do século $X X$ renovados por coleções e propostas mais adequadas ao público, ampliando o interesse e visando a maior aproximação com o público leigo".

As mudanças relacionadas ao caráter e objetivos dos museus, centradas na democratização do acesso e no caráter educativo, culminaram nas décadas de 1960-70 em uma visão de que os museus deveriam assumir uma função social e superar os limites de uma cultura voltada para a produção e circulação de bens culturais das elites (PAIVA e PRIMON, 2013). Esse movimento é chamado de Nova Museologia, e é dentro desse contexto que é cunhada a definição do ICOM, que reforça o caráter público e as finalidades de estudo e educação, divertimento e testemunhos culturais e ambientais. Para as autoras, a responsabilidade social dos museus é assim ampliada, repercutindo nas práticas desenvolvidas nesses espaços, que deveriam então priorizar a diversidade 
cultural, integrando os museus às distintas realidades locais (PAIVA e PIVON, 2013).

Esse breve histórico ajuda a entender que as funções de colecionar, conservar, estudar, interpretar, expor e transmitir conhecimento, destacadas por Poulot (2013), foram sendo construídas e, mais do que isso, ressignificadas, ao longo da história dessas instituições.

Entretanto, Valente (2003) ressalta que a trajetória dos museus não é linear e que, portanto, resistências e permanências ainda convivem nas práticas atuais. Essa reflexão é fundamental para olhar que tipo de conhecimento e formação científica ocorre dentro desses espaços.

\section{1.}

\section{O papel da educação nas instituições museais}

A partir da história das instituições museais, é possível perceber que as diferentes funções a elas atribuídas foram sendo construídas ao longo do tempo. A educação não é uma função inerente ao museu desde sua origem, mas passou a ganhar importância no final do século XIX, quando foram criados os primeiros setores educativos europeus.

Martins (2011), em sua tese de doutorado, buscou compreender as especificidades da educação nessas instituições. Para tanto, a autora partiu das transformações que contribuíram para o crescimento da importância da educação nesses espaços.

A autora, considerando as tendências pedagógicas ${ }^{34}$ como fruto de uma concepção de ensino intencional e planejada, e que ocorre em paralelo com o desenvolvimento das sociedades e dos campos de produção do conhecimento, buscou compreender as tendências que influenciaram a educação em museus. A seguir é feita uma breve descrição dessas influências identificadas em seu trabalho.

A grande aceitação das Pedagogias Renovadas ${ }^{35}$ na Europa e EUA no final do século $X I X$, início do século $X X$, levou à adoção de programas

\footnotetext{
${ }^{34}$ A autora utilizou a classificação proposta por Libâneo (1991) que divide as tendências pedagógicas nas que possuem caráter liberal (pedagogia tradicional, pedagogia renovada e tecnicismo educacional) e as de caráter progressista (pedagogia libertadora e críticosocial dos conteúdos).

${ }^{35}$ Martins (2011) explica que as Pedagogias Renovadas correspondem a várias correntes pedagógicas distintas que tinham em comum a ideia de modernização da educação. No Brasil, as Pedagogias Renovadas pautaram o Movimento da Escola Nova.
} 
sistemáticos de visitação escolar aos museus. De acordo com Martins (2011), apesar das visitas escolares já existirem anteriormente, elas não tinham objetivos educacionais muito claros. No mesmo período, os museus ingleses passaram a produzir kits de empréstimo de materiais para professores, influenciados pelo método intuitivo de lição das coisas de Pestalozzi ${ }^{36}$. Os setores educativos dos museus se constituíram, portanto, intimamente ligados a ações educativas direcionadas às escolas e ao público escolar.

Esse processo de estruturação dos serviços educativos relacionado a demandas da educação formal, iniciado na Europa e EUA, também ocorreu no Brasil. Em 1927, foi criado o Serviço de Assistência ao Ensino de Ciências Naturais ${ }^{37}$ do Museu Nacional do Rio de Janeiro, primeiro setor educativo de museus brasileiros, que teve como missão inicial a assistência às escolas. A partir da década de 1940, passou-se a ter efetivamente uma preocupação pedagógica dentro dos museus brasileiros, mas ainda seguindo o sentido de apoio à educação escolar. Para Martins (2011):

[...] a lição das coisas, no bojo das Pedagogias Renovadas, constitui-se como uma importante influência para o início da estruturação dos setores educativos nos museus europeus, norte-americanos e, mais tarde, brasileiros. As ações para o público escolar e o uso de objetos como referência para o ensino nessas instituições foi amplamente disseminado, levando à configuração de serviços educativos nos quais o atendimento ao público escolar se tornou uma prioridade (MARTINS, 2011, p. 76).

A autora discute que, se por um lado as Pedagogias Renovadas justificaram o uso educacional dos museus, o que levou à criação dos setores educativos nessas instituições, as Pedagogias Tradicionais forneceram a base conceitual sob a qual muitas atividades educativas foram desenvolvidas nos museus. Acrescenta que, apesar de distintas, as Pedagogias Tradicionais e Renovadas, sendo correntes liberais, não criticavam as finalidades da educação e os arranjos educacionais existentes.

Nesta perspectiva, as exposições e as atividades educativas dos museus permaneciam pautadas em um modelo de transmissão do conhecimento sobre os fatos da ciência, da técnica, das escolas artísticas

\footnotetext{
${ }^{36}$ Johann Heinrich Pestalozzi (1746-1827) foi um pedagogo suíço.

${ }^{37}$ Hoje chamada de Seção de Assistência ao Ensino, como será discutido no capítulo 5.
} 
e dos grandes feitos da humanidade, com uma concepção de museu ainda muito próxima a uma ideia positivista do século XIX de espaço de transmissão da verdade.

É apenas a partir da década de 1960, com a Nova Museologia, que a forma como eram desenvolvidas as atividades educativas passam a ser questionadas. Esses questionamentos também sofrem influências das teorias críticas que consideram o contexto social e escolar à luz das relações de poder. Martins (2011) também discute a possibilidade da influência dos Estudos Culturais nos museus, embora afirme não haver estudos que abordem a relação dos setores educativos com essa temática. Essas novas perspectivas teóricas levam em consideração uma maior participação do público nas esferas decisórias dos museus ${ }^{38}$.

Nesse mesmo período, são ampliados os debates sobre a participação pública na ciência, bem como persistem as discussões sobre a forma como a ciência e a tecnologia são divulgadas e disponibilizadas para a população, que influenciaram a educação em ciências como um todo.

Considerando a mudança da importância das dimensões da pesquisa e da educação nos museus ao longo do tempo, e também as mudanças nos sentidos do ensino de ciências, na seção seguinte será feita uma breve apresentação sobre a produção do conhecimento nos museus de ciência.

\section{2. \\ Os museus de ciências e a produção do conhecimento}

Dentro do grupo de museus considerados como museus de ciências, é possível identificar instituições que tem origens históricas distintas, o que pode impactar no tipo de conhecimento produzido e nas atividades educativas ofertadas.

Esses museus podem ser vistos a partir de diversas óticas, correspondentes a concepções distintas da ciência e da técnica, mas também a partir da relação promovida com o seu público. Em outras palavras, a compreensão dessas instituições pode ser feita a partir de

\footnotetext{
38 Martins (2011) lembra que essa mudança do papel do público não ocorreu sem que houvesse tensões e que até hoje suscitam o debate no campo da Museologia.
} 
abordagens que conferem a esses locais perfis distintos, que se refletem nas diferentes exposições, que podem ser caracterizadas segundo a forma de negociação estabelecida com o visitante (VALENTE, CAZELLI e ALVES, 2005).

O trabalho de McManus (1992) caracteriza os museus de ciência pelas temáticas que deram origem a sua criação em três gerações, que serão brevemente descritas a seguir.

\subsection{1.}

\section{Primeira geração: os museus de História Natural}

Os museus de História Natural surgem ao final do século XVII. Até então, objetos como fósseis, animais empalhados, moedas e instrumentos científicos eram acumulados nos "Gabinetes de Curiosidades" e abertos a um público seleto (CAZELLI, MARANDINO e STUART, 2003). Com a criação dos museus de História Natural, as coleções passam a ser reorganizadas e assumem o papel de demonstração, estudo e difusão do conhecimento científico. Essa organização dos objetos passou a ser mais sistemática, influenciada, no século seguinte, pelo "sistema natural de Lineu 39" (MARANDINO, SELLES e FERREIRA, 2009).

Os museus de História Natural têm em sua origem, como objetivo principal, a produção do conhecimento científico a partir do estudo dos objetos do acervo e não a educação do público. Nesse contexto, os itens encontrados na exposição não são os mesmos utilizados na pesquisa, pelos especialistas. Sendo assim, esses museus tinham uma ligação estreita com a academia e com a educação voltada para o público que a princípio não se constituía como uma meta (CAZELLI et al., 2002).

Para Valente e colaboradoras (2005), essas instituições privilegiam uma abordagem ontológica, em que originalmente a relação com o seu público de constitui de duas formas:

[...] aos visitantes predominantemente leigos, que compõem o público geral, procuram mostrar os extratos do mundo natural, vegetal, mineral e animal; para o público de especialistas, oferece a oportunidade de elaborar e

\footnotetext{
${ }^{39}$ Em 1735, o naturalista sueco Karl von Linée (1707- 1778), ou Lineu, como é conhecido em português, criou um sistema de classificação dos animais e plantas que ficou conhecido como "Sistema Natural de Lineu", utilizado até hoje por taxonomistas. Esse sistema divide os seres vivos em sete categorias taxonômicas: Reino, Filo, Classe, Ordem, Família, Gênero e Espécie.
} 
verificar, pela pesquisa, as teorias sobre a ordem da natureza e sua evolução. São os museus de História Natural, e a eles podem ser agregados os parques, zoológicos e jardins botânicos (VALENTE, CAZELLI e ALVES, 2005, p. 192).

Entretanto, de acordo com Marandino e colaboradoras (2009), esse papel central na produção de conhecimento foi sendo perdido ao longo do tempo para as universidades, o que se torna ainda mais evidente no século XIX. Nesse período, os museus de História Natural sofrem modificações nas exposições, que se tornam mais didáticas. Há também uma dissociação entre a coleção de pesquisa e as exposições, que passam a ter uma organização temática, revelando uma maior preocupação com os visitantes. Os dioramas (representações cenográficas que reconstituem o meio em que os espécimes estão inseridos) são característicos desse período. Para Cazelli e colaboradores (2002), com o tempo, o foco das exposições muda de uma organização taxonômica dos objetos para a exploração dos conceitos científicos, podendo ocorrer, inclusive, a introdução de aparatos interativos.

\subsection{2.}

\section{Segunda geração: ciência e indústria}

Ainda no século XIX, surge uma nova geração de museus de ciências, com o objetivo de promover o mundo do trabalho e os avanços científicos. Esses museus foram também influenciados pelas grandes exposições e pelas feiras internacionais realizadas até a Segunda Guerra Mundial. As exposições serviam como monumentos à capacidade técnica para que a sociedade industrial manifestasse seu orgulho e eram palco de convicção no progresso, na ciência e na técnica. Ao contrário dos museus de História Natural, os de Ciência e Indústria tinham "finalidades pública e de ensino mais explícitas que o da primeira geração" (CAZELLI, MARANDINO e STUART, 2003, p. 86).

$\mathrm{Na}$ análise de Valente e colaboradoras (2005), os museus de Ciência e Indústria seguem uma abordagem histórica, que molda instituições que destacam artefatos relevantes da história da ciência e da técnica, tratando de inovações que afetam o cotidiano das sociedades, como a invenção da máquina a vapor e da eletricidade. 
Como o objetivo dessa geração de museus era valorizar o desenvolvimento científico e tecnológico, muitos museus de ciência e indústria adotaram em suas exposições aparatos interativos. A partir da interatividade manual, ou hands on, o visitante obtinha um tipo de resposta. A ênfase que a participação do público passou a ter nesses museus é fruto da influência dos preceitos das Pedagogias Renovadas. As correntes tecnicistas também são percebidas na elaboração de displays em que respostas certas acendiam luzes ou emitiam sons, e em aparatos interativos que apresentavam uma única resposta certa, sem provocar o controle de variáveis. Muitos desses aparatos eram acionados a partir do aperto de botões, o que posteriormente denominou-se push-botton (CAZELLI et al., 2002).

De acordo com Martins (2011), apesar das críticas sofridas por esse tipo de interação limitada, os museus de segunda geração têm o mérito de inserir pela primeira vez a discussão de temas científicos a partir das consequências e implicações sociais acarretadas pelo uso da ciência e da tecnologia. Além disso, a partir da influência dos museus de terceira geração, essas instituições foram incorporando abordagens interativas mais abrangentes em suas exposições (CAZELLI et al., 2002).

\subsection{3.}

\section{Terceira geração: fenômenos e conceitos científicos}

A partir da década de 1960, as questões associadas ao impacto da ciência na sociedade, à compreensão que a população tem dos estudos científicos e das políticas públicas que envolvem assuntos sociocientíficos controversos, à imagem da ciência dentro e fora da comunidade científica tomaram uma dimensão significativa, quando se constatou os baixos índices do entendimento do público acerca da ciência. Os museus de terceira geração surgem então nesse contexto de preocupação educacional com a melhoria do ensino de ciências (CAZELLI, VALENTE e ALVES, 2003).

Neste contexto, há uma transformação dos museus, que passam a se entender como um espaço importante para proporcionar à sociedade informações científicas necessárias para a compreensão do mundo em 
mudança. A marca registrada dessa geração de museus é a maior interatividade do público quando comparada às gerações anteriores. As críticas à interação estritamente manual fazem surgir alternativas que procuram garantir o engajamento intelectual do visitante (minds on) por meio de uma interação física e dinâmica, não restrita a simples toques (CAZELLI et al., 2002).

Essa geração de museus traz, portanto, de forma mais efetiva, o papel da ação do sujeito na sua própria aprendizagem. Em muitos desses espaços, observa-se a adoção de conceitos construtivistas, como abordagem das concepções alternativas sobre ciência e questões exploratórias nos aparatos interativos. A ideia do "aprender fazendo", difundida no ensino de ciências nas décadas de 1970-80, também foi bastante presente (CAZELLI et al., 2002).

Esses museus seguem uma abordagem epistemológica, em que se procura comunicar ao visitante a forma como o processo científico se constrói e funciona, introduzindo o visitante no método científico a partir da "ciência em ação". Com essa abordagem, foram criados os Science Center que buscam a aproximação com $\circ$ público com preocupações marcadamente pedagógicas (VALENTE, CAZELLI e ALVES, 2005)

Segundo Cazelli e colaboradoras (2003), as exposições passam a ter cada vez menos uma preocupação com o simples caráter de contemplação de objetos históricos e cada vez mais o foco nas ideias científicas, a serem construídas pelo público a partir da manipulação de aparatos e da ideia de se viver a experiência do fazer científico. Nessa geração de museus, a mediação assume um papel central.

O sucesso dos museus de terceira geração influenciou os museus de primeira e segunda geração, que foram modificando seus objetivos educativos e adotando novas possibilidades de interação com os visitantes.

Além das três gerações apresentadas, Cazelli e colaboradores (2002) consideram que é preciso pensar em uma pedagogia que leve em consideração as singularidades dos museus como espaços de educação não formal e que amplie a classificação apontada por McManus (1992), incluindo uma nova geração de museus que discuta as seguintes dimensões: a negociação entre o visitante e o objeto do conhecimento 
científico; a problematização do conceito de interatividade e uma abordagem social e cultural da ciência e da tecnologia ${ }^{40}$.

A análise das três gerações de museus de ciência permite perceber que, no século $X X$, essas instituições passam a ter como finalidade principal a alfabetização científica, divulgação e popularização do conhecimento científico. Desta forma, é possível afirmar que houve uma transição entre uma produção de conhecimento inicialmente baseada nos objetos que compunham as coleções para uma pesquisa voltada para a função educativa.

\section{3.}

\section{O papel da mediação na educação em museus}

Como discutido anteriormente, o protagonismo que a educação passou a ter nos museus de ciências não é uma exclusividade dessa tipologia de museus. De acordo com Marandino (2008), é na segunda metade do século $X X$ que os museus passam a ser reconhecidos como instituições intrinsecamente educativas. Para a autora, esse reconhecimento é resultado da criação do ICOM e do movimento da Nova Museologia.

Nesse mesmo período, constata-se o crescimento das discussões sobre o papel dos espaços não formais de educação. De acordo com Trilla (2008), uma série de fatores, como o aumento da demanda por educação de setores sociais até então excluídos dos sistemas educacionais convencionais, as transformações no mundo do trabalho e o surgimento de novas tecnologias ligadas à informação levam a um debate sobre formas não escolares que atendessem às novas demandas educacionais.

A ampliação do debate sobre a importância da educação em espaços não formais ocorre em paralelo com as discussões sobre novas formas de ensino de ciências. Para Cazelli e Vergara (2007), os museus de ciência, como espaços de educação não formal, adquirem nesse contexto papel inquestionável na ampliação e refinamento do alfabetismo científico na sociedade.

${ }^{40}$ As dimensões são aprofundadas em Cazelli et al. (2002). 
Quando se pensa na dimensão educativa dos museus em geral, incluindo os de ciências, uma peça-chave parece ser a figura do mediador. Para Rodari e Merzagora (2007), o termo mediador é atribuído a todas as pessoas provedoras de conteúdo que trabalham em contato direto com visitantes nos museus, seja como facilitadores, guias, animadores, funcionários encarregados pelos laboratórios didáticos, shows etc. Os autores consideram que esses profissionais têm um enorme potencial, no sentido de que são os únicos que dialogam diretamente com os visitantes, e assim, podem, ao menos em teoria, interpretar melhor os novos modelos de comunicação da ciência.

O mediador pode receber diversas denominações, como as citadas acima (incluindo-se a de monitor). Gomes (2013) discute que a existência de várias denominações expressa diferentes concepções sobre qual papel esse profissional deve exercer. Neste trabalho, optou-se pelo uso do termo mediador, entendendo esse sujeito como alguém que vai promover o diálogo entre o público e o discurso expositivo.

Cabe ao mediador "a tarefa de tornar o conhecimento produzido acessível aos mais variados públicos, despertando curiosidades, aguçando interesses, promovendo o contato com o patrimônio" (MARANDINO, 2008. p. 5).

Para Gomes (2013), considerando a atual concepção e papel dos museus de ciência, pode-se entender que o mediador deve ser capaz de aguçar a curiosidade do visitante mais do que expor conceitos científicos.

O mediador, assim como o museu, não deve ter como objetivo ensinar ciência, mas sim dialogar sobre ciência, a partir dos questionamentos do visitante. Para isso é imprescindível o domínio dos saberes de referência abordados nas exposições e a capacidade de seduzir o público, o que envolve inúmeras habilidades, tornando a mediação multifacetada e complexa (GOMES, 2013, p. 34).

Considerando a importância desses profissionais para as experiências educativas nos museus em geral, e nos de ciência em particular, inúmeras pesquisas têm se dedicam a compreender e avaliar as atividades de mediação. Esses trabalhos têm buscando identificar as pessoas que atuam como mediadores, qual sua formação e se há uma formação específica para atuar nesses espaços. 
A pesquisa de Rodari e Merzagora (2007) em museus de ciências europeus mostra que apesar de haver um consenso sobre a importância da "interface humana" nesses espaços, são dedicados poucos investimentos para sua avaliação e capacitação. Os autores acrescentam que raramente as atividades de capacitação de mediadores inclui um suporte teórico sobre educação não formal e teorias sobre comunicação da ciência. Além disso, os mediadores não são envolvidos nas primeiras etapas de planejamento das atividades oferecidas pela instituição onde trabalham, não são treinados para analisar e avaliar os objetivos, impactos e resultados do seu trabalho e, por fim, raramente o conhecimento que esses sujeitos acumulam sobre público, assim como a avaliação que realizam sobre as estratégias de comunicação, são coletados e/ou valorizados pelo museu.

Se pensarmos no protagonismo que o diálogo com o público passa a ter nas instituições museais no século $X X$, fazendo com que os museus busquem cada vez mais se reestruturar em função dos públicos que deseja atrair e alcançar (BRITTO, 2005), o mediador assume um papel que vai muito além de ser um mero explicador, e passa a ser uma possibilidade fundamental de diálogo entre os diferentes públicos e a instituição.

Durante o processo de mediação, também é preciso estar claro que a aprendizagem em museus é distinta da aprendizagem escolar de ciências. Para Padró (2005), museus são considerados locais de educação não formal e de ócio para todas as idades. Lugares para combater a exclusão social, promover a cidadania ativa, o desenvolvimento pessoal e a inovação. Esta perspectiva deve estar presente em visitas individuais ou em grupo, com visitantes de todas as idades. Assim, é importante que os museus percebam a importância de criar oportunidades para a aprendizagem nas ações desenvolvidas, além de políticas de investigação e avaliação desses processos.

Considerando essa perspectiva, para o mediador, deve estar claro que aprender no museu é diferente de aprender na escola. É também necessário a compreensão, como afirma Padró (2005), de que a Educação em Museus é uma outra esfera de produção de discursos. Para Marandino 
(2008), há de se compreender que no museu é construído um discurso expositivo e que esse discurso é

[...] fruto de adaptações e transformações de vários outros discursos científico, educacional, comunicacional, museológico, entre outros determinadas pelas finalidades e objetivos da exposição e também pelas especificidades de tempo, espaço e objetos nos museus, que, por sua vez, configuram certa linguagem específica de comunicação com o público (MARANDINO, 2008. p. 20).

A breve reflexão aqui apresentada sobre as especificidades da Educação em Museus, e sobre o trabalho dos mediadores, torna claro que um mediador idealmente deve possuir diversos saberes, que perpassam pelos saberes das ciências de origem, por saberes relacionados a teorias de aprendizagem, às particularidades e objetivos da educação não formal, pelos saberes sobre as questões socioculturais do público que frequenta o museu, entre outros. Logo, a formação desses profissionais é complexa e fundamental para que sua atuação de fato contribua para que uma visita a um museu de ciências se configure como uma aprendizagem significativa. É preciso aqui ponderar que a compreensão de uma exposição não se dá apenas quando mediada por uma pessoa, mas, de acordo com Marandino (2008), a mediação humana parece ser a melhor forma de garantir que a mensagem proposta pelos idealizadores da exposição seja compreendida pelo público.

Dentro dessa reflexão sobre os saberes necessários a um mediador, cabe também o seguinte questionamento: será que há saberes que são próprios da mediação? A partir de uma pesquisa sobre a atuação de mediadores no Museu de Astronomia e Afins (MAST), Queiroz e colaboradoras (2002) encontraram saberes que se relacionam com os saberes escolares e da educação em ciências. Entretanto, perceberam saberes que marcam mais fortemente a mediação museal, mesmo que ainda exista uma correspondência com o reduto escolar. As autoras dividem esses saberes em três categorias:

I) Saberes compartilhados com a escola.

II) Saberes compartilhados com a escola no que diz respeito ao ensino de ciências.

III) Saberes mais propriamente de museus. 
No primeiro grupo, as autoras incluem o saber dos conteúdos disciplinares, da transposição didática, da escolha da linguagem adequada aos diferentes tipos de públicos e que favoreçam o diálogo. No que se refere aos saberes do ensino de ciências, estão incluídos o saber sobre a história da ciência, sobre os processos de construção do conhecimento científico, e sobre as visões alternativas ao conhecimento científico (como o senso comum, por exemplo). Por fim, em relação aos saberes que são mais específicos dos museus, Queiroz e colaboradoras (2002) citam o saber da história da instituição, saber interagir com os docentes presentes em uma visita escolar, o saber da conexão - que se refere a conectar diferentes espaços e atividades de uma mesma exposição -, o saber da história da humanidade, o saber da expressão corporal, o saber da manipulação de aparatos e demais objetos e experimentos, o saber da ambientação - que se refere a conhecer características do ambiente da exposição tais como luz, cor, estilo do mobiliário.

Tenho dúvidas se todos esses saberes são próprios da Educação em Museus, uma vez que um professor também pode usar esses saberes em sua prática docente, quando, por exemplo, conhece a história de sua escola e utiliza esse conhecimento em sua prática, bem como os saberes sobre a história da humanidade, como quando discute a evolução humana. Por outro lado, o professor também precisa ter saberes relacionados à expressão corporal e à manipulação de objetos em aulas práticas, e na própria visita a museus interativos, onde poderá manipular os aparatos e objetos e dialogar com seus alunos. Mas esses saberes certamente são importantes para a atuação do mediador na instituição museal.

As autoras elencam também, como um saber próprio dos museus, o saber da concepção da exposição, que seria "saber das ideias das pessoas que idealizaram, planejaram e executaram a exposição, o que inclui o saber da tendência pedagógica da exposição" (QUEIROZ et al., 2002. p. 13). Entretanto, indicam que se configura como um "saber desejável", já que não identificaram esse saber durante a atuação dos mediadores nas visitas. Esse saber se relaciona com a discussão já mencionada por Rodari e Merzagora (2007) de que os mediadores deveriam participar inclusive dos 
processos de elaboração e montagem das exposições, bem como das ações educativas.

Gomes e Cazelli (2016) avaliaram os saberes mobilizados na formação de mediadores em dois museus de ciência. Para tanto, as autoras tomaram como base os saberes docentes elencados por Tardif (2010). Nessa perspectiva, o saber docente é composto pelos saberes da formação profissional, os saberes disciplinares, os saberes curriculares e os da experiência.

Para as autoras, é importante que um mediador tenha domínio sobre os conteúdos temáticos das exposições em que trabalha, associado ao saber disciplinar. Ou seja, para Gomes e Cazelli (2016), conhecer os conteúdos seria importante para que o mediador não seja um mero transmissor de informações previamente selecionadas por outros, mas capaz de dialogar com o público.

Para que o diálogo seja possível, sem que o mediador apresente apenas uma visão de especialista, mas que possa provocar o interesse em diferentes temáticas, é imprescindível deter ferramentas que propiciem uma boa comunicação com diferentes tipos de público. Para tanto, o mediador precisa mobilizar conhecimentos das ciências da educação, aspecto associado por Gomes e Cazelli (2016) ao que Tardif (2010) considera como saberes da formação profissional.

As autoras também consideram que a prática do mediador no museu, como a prática de um professor

é conduzida em uma instituição com uma história, com normas, proposta museológica, museográfica e educativa, que a influenciam e podem ser compreendidas como um saber curricular (GOMES e CAZELLI, 2016, p. 30).

Por fim, para refletir sobre os saberes da experiência, Gomes e Cazelli (2016) lembram que Tardif (2010) considera que é no exercício cotidiano da profissão que os condicionantes aparecem relacionados a situações concretas, que exigirão dos docentes improvisação, habilidade pessoal e capacidade de enfrentar situações. Lidar com essas situações do cotidiano é formador, pois permite que o professor desenvolva um habitus que lhe permitirá enfrentar justamente os condicionantes da profissão. As autoras relacionam essa discussão de Tardif à reflexão 
proposta por Marandino (2008) de que o mediador em sua prática convive com situações inusitadas, as quais devem superar por meio da improvisação e criatividade, devido à heterogeneidade dos públicos e à complexidade dos processos de mediação em museus.

O trabalho de Queiroz e colaboradoras (2002) e o de Gomes e Cazelli (2016) reforçam a ideia de que a formação e a atuação dos mediadores como educadores em museus é complexa, uma vez que exige que esse profissional mobilize diversos saberes em sua prática. Aqui, cabe problematizar que o papel de mediador é exercido em geral por estudantes jovens, de ensino médio ou graduação, aos quais é atribuído um grande número de tarefas. Essa atuação costuma se dar de forma temporária, através de estágios, de forma voluntária (CAFFAGNI, 2010) ou sem que haja um vínculo empregatício com a instituição (ALENCAR, 2008; CARVALHO, 2016).

Retomando a discussão sobre os tipos de conhecimento produzidos nos museus, é possível afirmar que, embora haja uma discussão sobre o papel dessas instituições na historiografia da ciência, especialmente na construção da ciência moderna brasileira, como destacado por Lopes (2009), parece indiscutível que a história da educação nos museus, e dos próprios museus de ciências, fez com que hoje essas instituições se configurem como importantes espaços de educação não formal de ciências e protagonistas nos processos de divulgação e popularização do conhecimento científico.

Dentro desse contexto, os mediadores assumem um papel-chave, por aumentarem as chances de que o objetivo de aprendizagem por trás da exposição seja alcançado, ou pelo fato de promoverem um diálogo direto com o público, capazes, inclusive, de avaliar se os objetivos traçados estão sendo atingidos. Conforme apontado pelos autores, para que esse diálogo aconteça é preciso que o mediador, em sua atuação, recorra a uma série de saberes, que vão desde os saberes ligados à ciência de origem, passando por saberes pedagógicos e por saberes próprios da educação não formal que ocorre em um museu, como a história da instituição que trabalha, concepção da exposição, características dos ambientes e salas, 
interface entre diferentes espaços e exposições e características socioculturais dos diferentes públicos (entre outras).

É certo que a formação de um mediador é complexa, uma vez que envolve toda essa gama de saberes. No que se refere à reflexão sobre a produção de conhecimento nos museus, cabe indagar: essa formação dos mediadores é apenas um treinamento para receber o público ou a mediação pode ser uma instância de pesquisa, produção de conhecimento e formação?

Esse questionamento deriva do fato de que os museus de ciências atuais se configuram como espaços de produção de conhecimento sobre a divulgação e popularização da ciência, e, portanto, formam (ou deveriam estar formando) pesquisadores nessa área. Como se dá então essa formação? Será que essa formação se dá associada, dissociada ou em paralelo aos processos de mediação? Essas são questões que serão aprofundadas no capítulo 6 .

Se levarmos em consideração as reflexões de Rodari e Mertagoza (2007) sobre a necessidade de que o mediador participe dos processos de concepção e avaliação das exposições, é possível afirmar que a formação e atuação dos mediadores não deveria estar descolada do processo de produção de conhecimento que ocorre nos museus de ciências. 


\section{5. \\ O estágio de alunos bolsistas em museus de ciência}

Neste capítulo será feita uma descrição sobre como é o estágio em museus, com enfoque nos museus de ciência da cidade do Rio de Janeiro. A proposta inicial desta pesquisa era investigar os processos de iniciação científica e, para tanto, como descrito na metodologia, foi utilizado o questionário da pesquisa do GEPEMCI para que fosse possível saber quais museus da cidade possuem esse tipo de formação.

Das 85 instituições que responderam ao questionário, 14 afirmaram que possuíam alunos bolsistas de IC, e seis afirmaram ter esse tipo de bolsistas eventualmente. Dessas 20 instituições, 18 afirmaram possuir bolsistas de graduação, das quais quatro têm também bolsistas de IC-EM. Dois museus afirmaram possuir somente alunos de ensino médio.

Os museus que afirmaram possuir bolsistas de IC são de tipologias variadas, como Artes, História, Comunitário, Militar e de Ciência. Buscando compreender como ocorre a formação desses bolsistas, optou-se por investigar os museus de ciência. A escolha por essa tipologia de museu se deve ao fato de que, historicamente, essas instituições estiveram relacionadas à pesquisa e à formação científica. Dos museus que retornaram o questionário, 10 são de ciência e seis deles afirmaram possuir bolsistas de IC: o Museu Nacional, o Espaço Ciência Viva, o Museu de Astronomia e Ciências Afins, o Espaço Coppe Miguel Simoni, o Museu da Vida e o Museu da Química Athos da Silveira Ramos. Desse grupo de seis museus, todos responderam que possuíam bolsistas de graduação e três afirmaram que também possuíam bolsistas de ensino médio (Museu Nacional, Espaço COPPE e o Museu da Química).

Embora o Espaço COPPE se considere um centro de ciência e não um museu, é importante deixar claro que, neste trabalho, todas as instituições serão tratadas como museus. A divisão entre centro de ciência e museu parece estar relacionada ao fato dos museus terem coleções a 
partir das quais se realizam pesquisas, enquanto os centros de ciência teriam um acervo mais voltado para fins didáticos, tendo como foco a difusão e popularização da ciência.

Essa divisão entre centros e museus de ciências parece não ser muito clara no Brasil, onde os centros de ciências sempre estiveram mais ligados ao desenvolvimento de metodologias ligadas ao ensino de ciências escolar (formal) (JACOBUCCI, 2008). Portanto, considerando a reflexão de Jacobucci e as definições das funções das instituições museais propostas pelo ICOM e por Poulot (2013), no desenvolvimento desta pesquisa não será feita a distinção entre museu e centro de ciência.

Para que os processos de formação dos bolsistas nos diferentes espaços possam ser melhor compreendidos, é necessária uma breve caracterização dos museus estudados. Não se pretende aqui produzir uma descrição extensa e sim um texto que contemple alguns aspectos relevantes, como o ano e contexto de criação de cada museu, sua localização e vínculos (se é ligado a outras instituições de pesquisa), sua estrutura organizacional e objetivos.

\section{1. \\ Os museus estudados}

A descrição dos museus segue a ordem cronológica em que foram fundados e é importante ressaltar que essas instituições podem ter semelhanças ou distanciamentos em relação a esses contextos e ao número de pesquisas que já foram produzidas sobre ela, o que leva a uma certa discrepância em relação ao volume de informações apresentadas a seguir. As fotos ilustrativas foram retidas das páginas da internet e redes sociais das instituições.

Uma diferença marcante é que um dos museus, o Museu Nacional, foi criado no século XIX, sendo um museu de História Natural (museu de ciência de primeira geração), enquanto os demais são museus de Ciência e Tecnologia (museus de terceira geração) e foram implantados entre as décadas de 1980 e 2000. 
De acordo com Seibel-Machado (2009), a criação dos museus de Ciência e Tecnologia no Brasil se insere em um movimento mais amplo em que governos e instituições de diferentes países são levados a se preocuparem com

[...] o alto grau de desinformação e desconhecimento do grande público, a respeito de questões científicas e tecnológicas presentes no cotidiano do cidadão, e investem na criação, reestruturação e fortalecimento dos museus de ciência com o objetivo de contribuir para a 'alfabetização científica'41. (SEIBEL-MACHADO, 2009, p. 135).

Aqui é importante salientar que o termo Alfabetização Científica pode possuir diversos significados. Cerati (2014), em um exercício teórico de entender a polissemia desse conceito, diz que a Alfabetização Científica, desde a sua concepção, é carregada de controvérsias, que incluem uma dificuldade de conceituação e diversidade de interpretações. Mesmo assim, a autora sugere que as mudanças na educação em ciências ocorridas nas décadas de 1980-90 sofrem influência de discussões iniciadas na década de 1960. Nesse período, a preocupação com as consequências do desenvolvimento científico para a sociedade era emergente, levando ao debate sobre a necessidade de promover no público a capacidade de elaborar um pensamento crítico com relação ao papel da ciência e tecnologia. Portanto, essa visão de Alfabetização Científica está atrelada à ideia de que os cidadãos tenham acesso aos conhecimentos científicos para que sejam capazes de se posicionar diante dos problemas e benefícios sociais que os avanços científicos e tecnológicos possam acarretar para si e para a sociedade em geral.

Tendo como objetivos a informação, a divulgação, a comunicação e a educação em ciências, esses museus de C\&T manifestam claramente preocupações educacionais voltadas para a melhoria do ensino de ciências e adotam uma perspectiva pedagógica de tendência construtivista na elaboração e desenvolvimento de suas ações educativas (CAZELLI, MARANDINO e STUDART, 2003).

Martins (2011) ressalta que o surgimento dessa tipologia de museus no Brasil ocorre no contexto de redemocratização, estando vinculado a uma

\footnotetext{
${ }^{41}$ Aspas da autora.
} 
perspectiva de maior participação da população nos rumos e decisões políticas em diversos âmbitos, inclusive o científico.

É importante destacar que, como discutido por Valente (2003), mesmo os museus de História Natural, originalmente ligados à produção de conhecimento nas áreas das Ciências Naturais, foram assumindo com o tempo um papel de comunicação do conhecimento e, posteriormente, tiveram influência dos processos de difusão e experimentação trazidos pelos museus de Ciência e Tecnologia. Segundo a autora, os museus não têm uma trajetória linear e apresentam, ao longo de sua história, movimentos de resistências e permanências. Portanto, cabe entender o contexto em que cada instituição se constituiu para que seja possível compreender as suas práticas.

\subsection{1.}

\section{O Museu Nacional}

O Museu Nacional foi criado em 1818, quando então era chamado Museu Real do Rio de Janeiro, e se configura como uma das primeiras instituições científicas do Brasil. Está localizado na Quinta da Boa Vista, bairro de São Cristóvão, Zona Norte da cidade do Rio de Janeiro desde $1892^{42}$ (Figura 1 e Figura 2). De acordo com Lopes (2009), o Museu se estabeleceu como uma instituição dedicada às Ciências Naturais, já rompendo com os modelos de museu-gabinete característicos do fim do século XVIII. Para a autora, essa tentativa de ruptura se baseava nas concepções científicas da época, que já identificavam os caminhos de especialização nessas ciências.

O Museu funcionou desde o início até o final do século XIX como órgão consultor governamental para assuntos ligados à Geologia, Mineralogia e recursos naturais. O caráter consultivo prioritário não impediu que fossem desenvolvidas pesquisas em outras áreas, e se apresenta como a instituição responsável pelo início da pesquisa no país em Paleontologia, Zoologia e Antropologia (LOPES, 2009).

\footnotetext{
42 Até 1892 o Museu estava localizado no Campo de Sant'Anna, região central da cidade.
} 


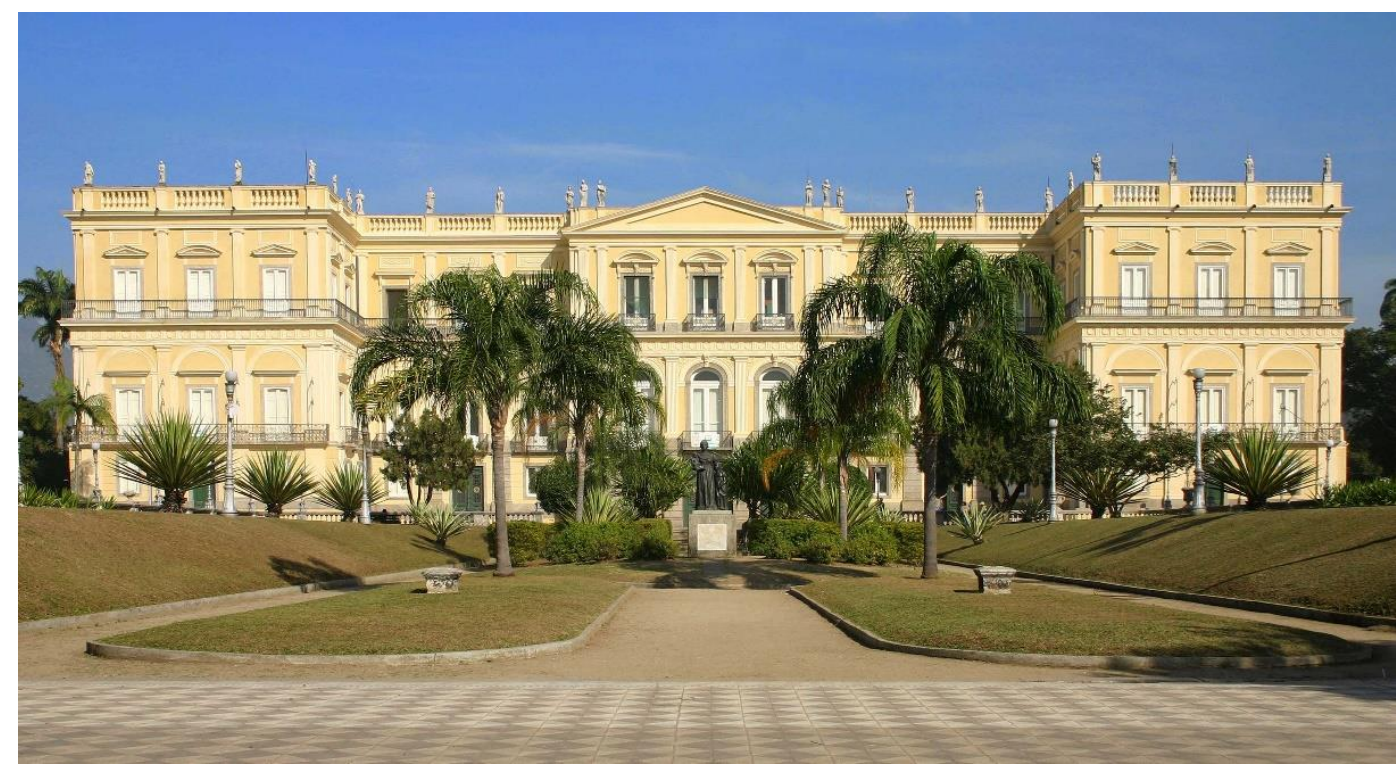

Figura 1: Foto da fachada do Museu Nacional.

Fonte: <https://ufrj.br/sites/default/files/Fachada-Museu-Nacional-alta-qualidade.jpg>. Acesso em: 17 dez. 2017

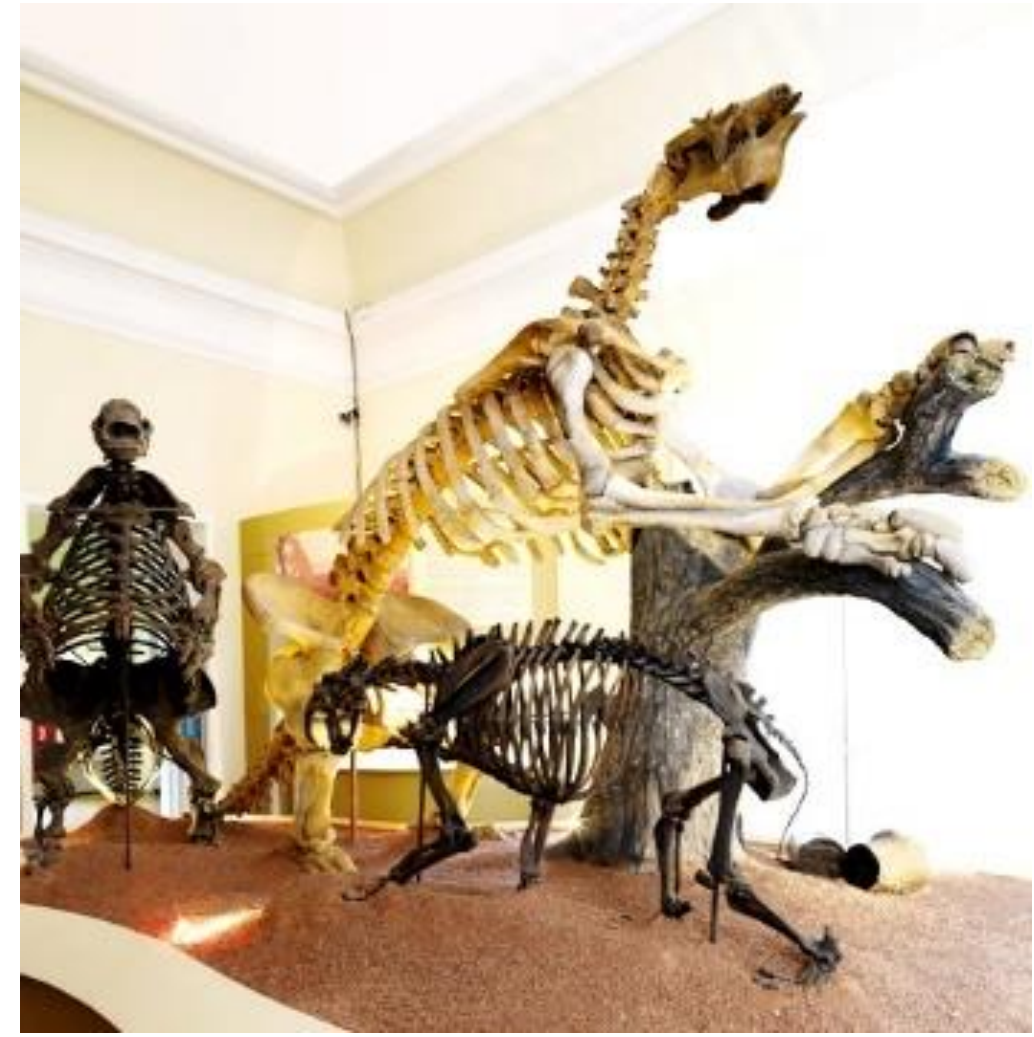

Figura 2: Foto do interior do Museu Nacional, com parte da exposição do acervo de paleontologia.

Fonte: <http://www.museunacional.ufrj.br/dir/exposicoes/paleontologia/pale033.html>. Acesso em: 17 dez. 2017. 
Além da importância na institucionalização da Ciências Naturais e na profissionalização dos naturalistas, o Museu fez parte de iniciativas pioneiras em torno da educação em Ciências. Ao longo do século XIX, compartilhou professores, cedeu salas, coleções e instrumentos para a Faculdade de Medicina; ministrou aulas de História Natural e Mineralogia para a Escola Militar, além de cursos para o Colégio Pedro II (LOPES, 2009).

Em 1946, o Museu Nacional passa a incorporar a então Universidade do Brasil, hoje Universidade Federal do Rio de Janeiro (UFRJ). Handfas e colaboradores (2016) se apoiam em Lopes (2009) e Schwartzman (2015) para discutir que essa transferência ocorre em um contexto do século $X X$ em que os museus perderam o prestígio como espaços produtores de conhecimento científico para as Universidades e Institutos de Pesquisa.

Aqui é importante destacar que a incorporação a UFRJ não reduziu o caráter de pesquisa do Museu Nacional, uma vez que ele abriga programas de pós-graduação Stricto Sensu (mestrado e doutorado) em diferentes áreas, como Antropologia Social, Arqueologia, Botânica, Geociências, Linguística e Línguas Indígenas e Zoologia.

Ainda em relação ao aspecto educativo, Roquette-Pinto ${ }^{43}$ criou, em 1927, o Serviço de Assistência ao Ensino de História Natural, hoje Seção de Assistência ao Ensino (SAE), primeiro setor educativo a ser inaugurado em um museu no Brasil. A SAE hoje busca promover a educação em ciências, a acessibilidade cultural e a popularização da ciência. Para tanto, realiza projetos e ações para o público escolar, para famílias, crianças, pessoas com deficiência e em situação de vulnerabilidade social. O setor desenvolve também estudos de público e pesquisas nos campos da educação museal e da acessibilidade. Além disso, são oferecidos cursos de extensão em parceria com outros departamentos, entre eles, os cursos "Formação de Mediadores do Museu Nacional"; "Descobrindo a Terra Formação Continuada de Professores em Educação em Geociências" e

43 Edgar Roquette-Pinto (1884-1954) foi um médico, pesquisador, naturalista e antropólogo brasileiro, com expressiva atuação nos movimentos ligados à divulgação da ciência. Ele criou o SAE quando era então diretor do Museu Nacional. 
"Meninas com Ciência: Geologia, Paleontologia e Gênero no Museu Nacional" (PIRES, 2017).

\subsection{2.}

\section{O Espaço Ciência Viva}

O Espaço Ciência Viva (ECV) foi fundado em 1983, por um grupo de cientistas, pesquisadores e educadores interessados em tornar a ciência mais próxima do cidadão comum. Inicialmente, as atividades eram realizadas em praça pública e em comunidades da Zona Norte da cidade do Rio de Janeiro. A partir de 1986, o ECV se estabeleceu em um galpão no bairro da Tijuca, também localizado na Zona Norte da cidade (COUTINHO-SILVA et al., 2005) (Figura 3 e Figura 4).

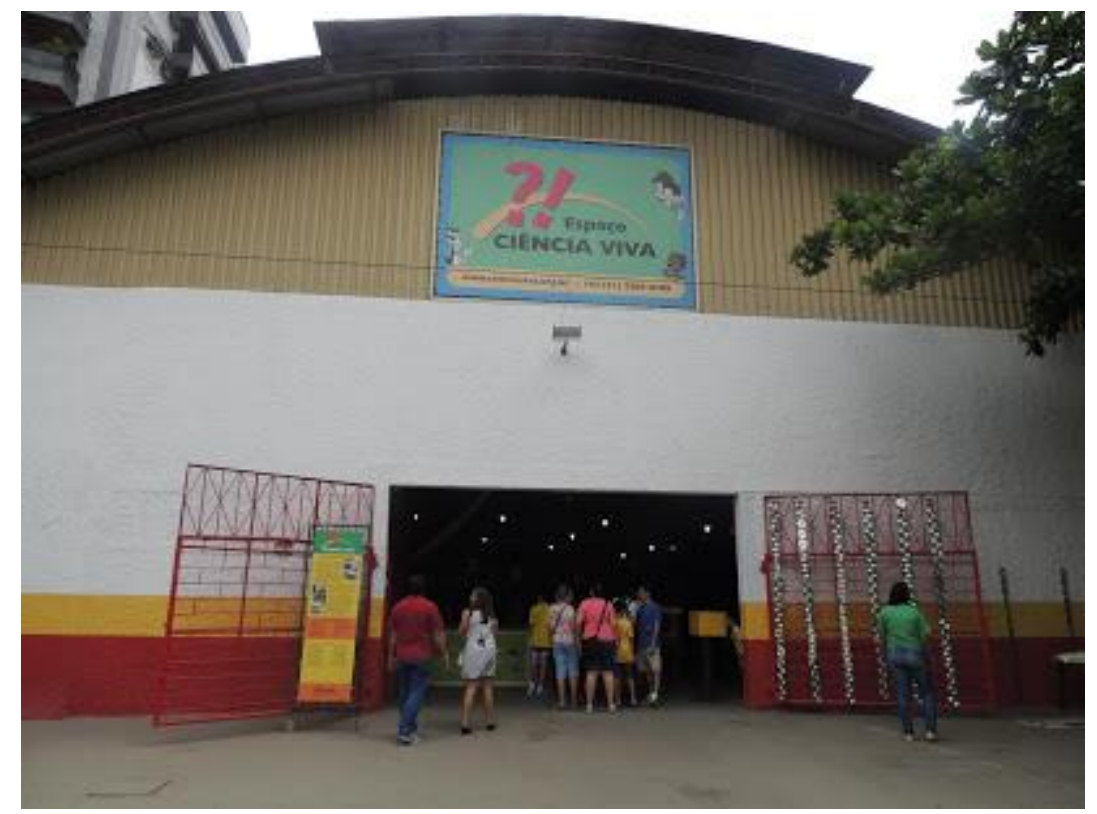

Figura 3: Foto da fachada do galpão onde funciona o Espaço Ciência Viva.

Fonte: <https://www.google.com/maps/contrib/101775652047440542883/photos>. Acesso em: 17 dez. 2017.

De acordo com Coutinho e colaboradores (2005), o objetivo da instituição é a divulgação e desmistificação da Ciência, tornando-a acessível ao senso comum, assim como a melhoria do ensino de ciências e da matemática. O Espaço mantém uma exposição permanente com módulos interativos em física, matemática, percepção, biologia, sexualidade, astronomia e música.

O ECV está organizado juridicamente como uma organização da sociedade civil sem fins lucrativos (GOMES, 2013). Durante a década de 
1990, o Espaço sofreu um esvaziamento do seu quadro de pessoal, o que levou a um decréscimo no número de atividades. Em 1998, foi empossada uma nova diretoria e, a partir daí, buscou-se uma reaproximação do Museu com universidades e centros de pesquisa (COUTINHO-SILVA et al., 2005). Parte dessa diretoria é composta por professores do Instituto de Bioquímica Médica da UFRJ, que desenvolvem projetos de extensão no ECV.

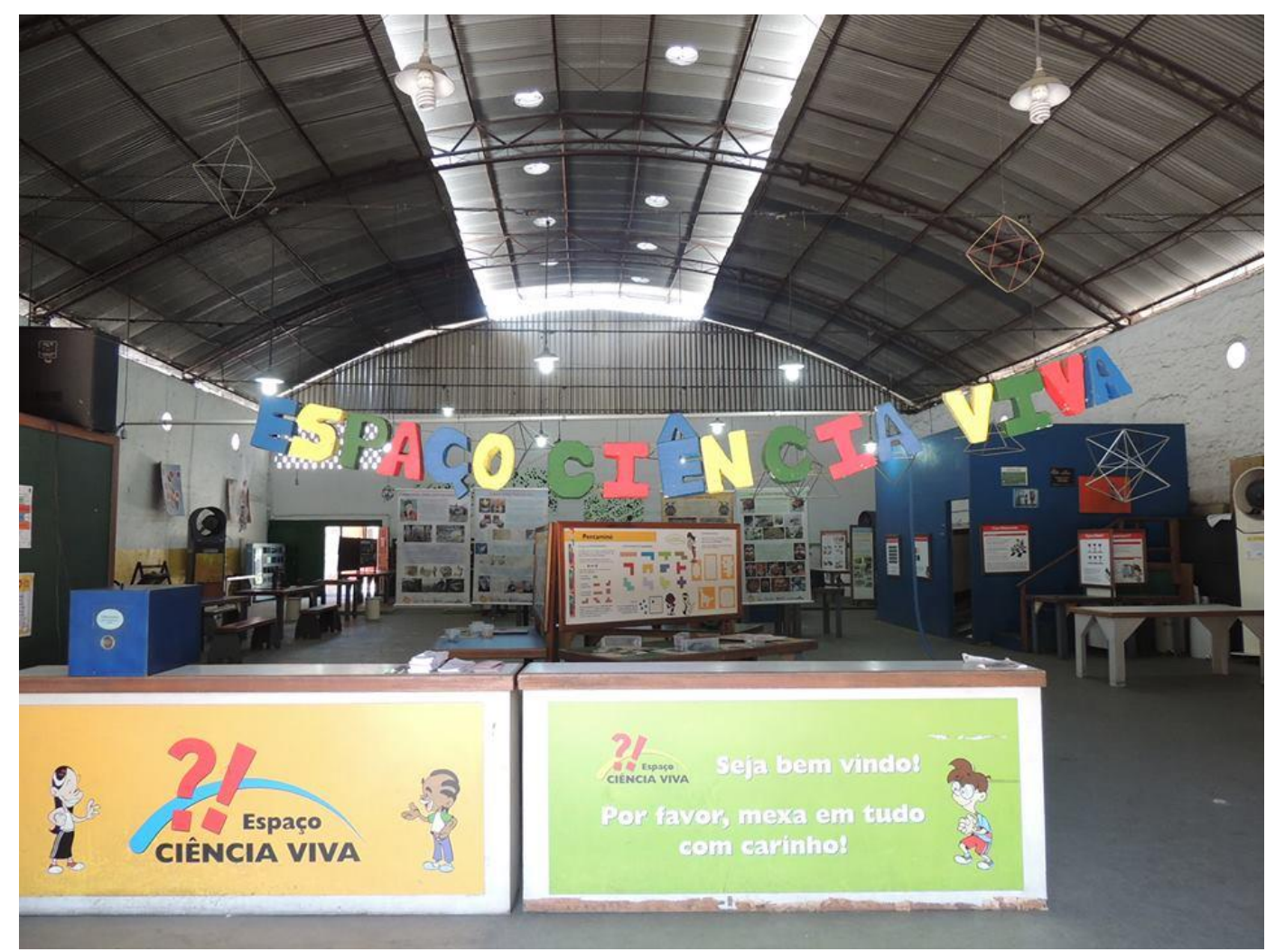

Figura 4: Foto do interior do galpão onde funciona o Espaço Ciência Viva.

Fonte: <https://www.google.com/maps/contrib/101775652047440542883/photos>. Acesso em: 17 dez. 2017.

O público principal do ECV é o público escolar, em especial os grupos agendados, mas também há atividades para o público espontâneo e para professores.

\subsection{3.}

\section{O Museu de Astronomia e Ciências Afins (MAST)}

O Museu de Astronomia e Ciências Afins foi criado em 1985, dentro do mesmo contexto descrito anteriormente, em que foram implantados os demais museus de ciência e tecnologia no Brasil voltados para a Alfabetização Científica nas décadas de 1980-90. Está localizado no bairro de São Cristóvão, Zona Norte da cidade do Rio de Janeiro, dentro do 
mesmo campus onde está situado o Observatório Nacional ${ }^{44}$ (Figura 5 e Figura 6).

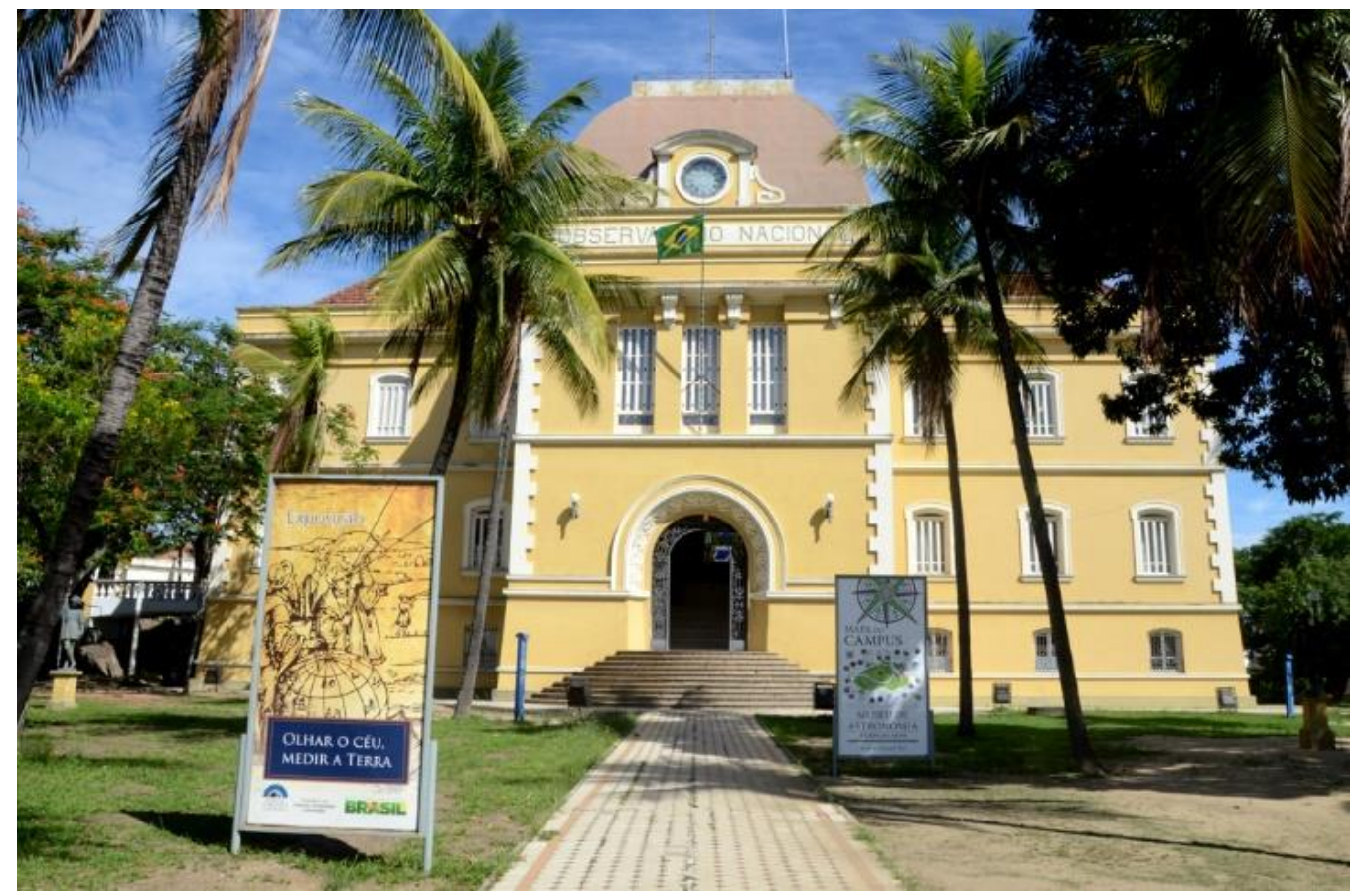

Figura 5: Foto da fachada do Museu de Astronomia e Ciências Afins.

Fonte: <http://www.mast.br/index.php/component/content/article.html?id=2792>. Acesso em: 17 dez. 2017.

A base inicial para a criação do MAST foi o Grupo Memória da Astronomia (GMA), criado em 1981 e composto por pesquisadores do Observatório Nacional. Esses pesquisadores estavam preocupados com a preservação do patrimônio ligado à Astronomia e às ciências afins no país. A partir da criação do grupo, iniciou-se o contato com instituições e pesquisadores da área de museus, História da Ciência e patrimônio, com o intuito de fomentar as discussões sobre a nova instituição que seria criada.

O Grupo deu origem, mais tarde, ao Projeto Memória da Astronomia no Brasil e Ciências Afins (PMAC) que foi o responsável por pensar o plano museológico que contemplaria os objetivos e as bases conceituais do futuro museu. As primeiras atividades destinadas ao público, como o Parque da Ciência, tinham ênfase no ensino de conceitos científicos por meio de

${ }^{44}$ O Observatório Nacional foi criado no período Imperial (1827) e é hoje um Instituto de Pesquisa ligado ao Ministério da Ciência, Tecnologia, Inovações e Comunicações (MCTIC). A missão institucional atual é realizar pesquisas em três grandes áreas de conhecimento - Astronomia, Geofísica e Metrologia em Tempo e Frequência. Além de formar pesquisadores e gerar, manter e disseminar a Hora Legal Brasileira. Para mais informações no site da instituição: <www.on.br>. Acesso em: 14 out. 2017. 
aparatos interativos e forte conexão com os currículos e público escolar. Essas atividades foram concebidas por equipes que contavam com diferentes profissionais, incluindo professores das redes municipal e estadual do Rio de Janeiro (MARTINS, 2011). ${ }^{45}$

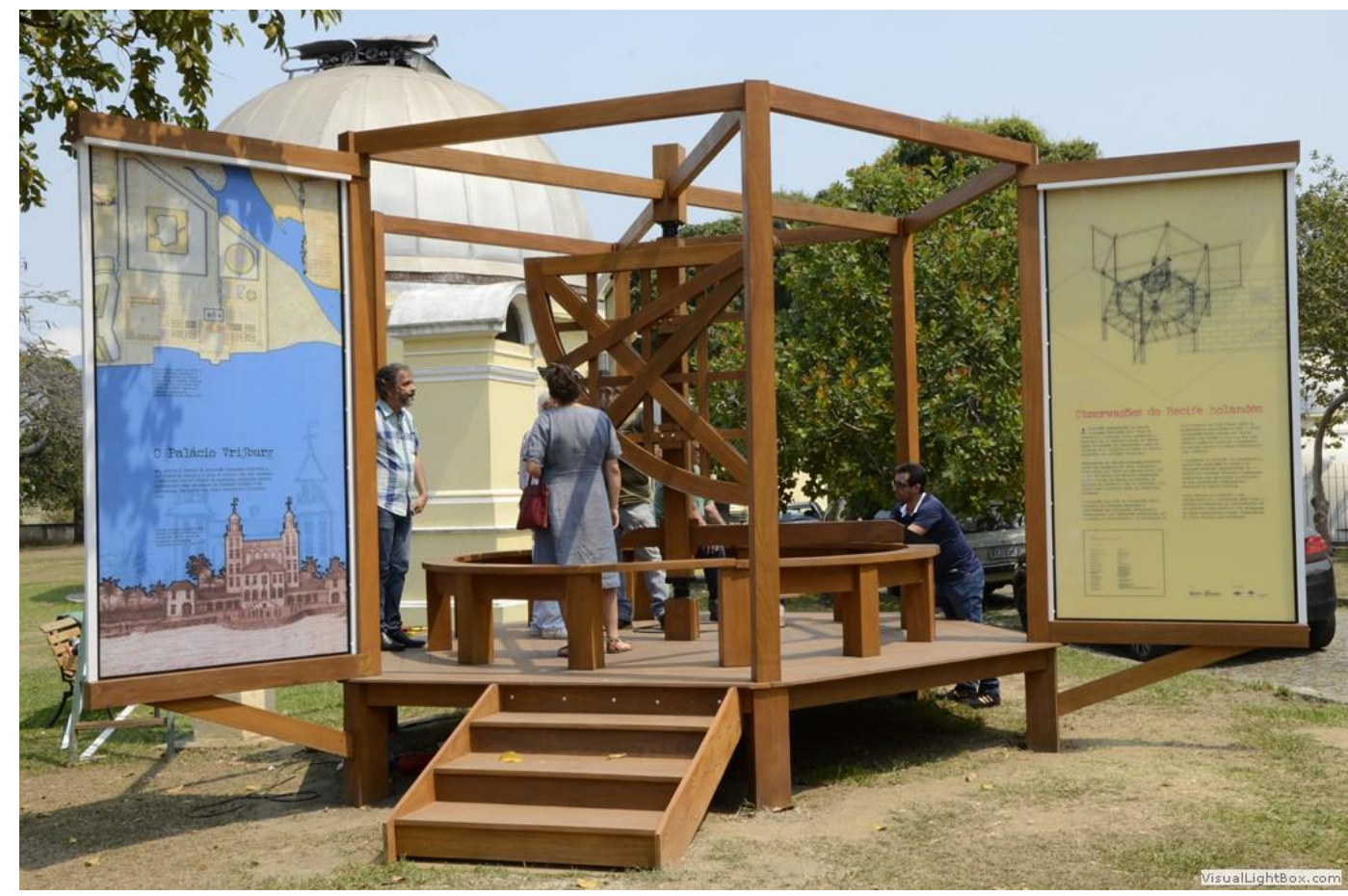

Figura 6: Foto de exposição na área externa do MAST sobre observações do Recife holandês. Fonte:

<http://site.mast.br/exposicoes_hotsites/exposicao_observacoes_do_recife_holandes/ galeria_fotos_files/vlb_images1/_dsc2458.jpg >. Acesso em: 17 dez. 2017.

Inicialmente o MAST era ligado ao CNPq, mas, conforme destacado acima, atualmente é um Instituto de Pesquisa vinculado diretamente ao Ministério de Ciência, Tecnologia, Inovações e Comunicações (MCTIC). O Museu tem, desde a sua concepção, uma forte vocação educacional, mas também apresenta entre seus objetivos a preservação do acervo científico nacional, em especial o acervo oriundo do Observatório Nacional, a pesquisa em História da Ciência, além da geração de conhecimento sobre esse acervo e sobre a difusão e a popularização da ciência (MARTINS, 2011).

A instituição está atualmente organizada em quatro coordenações: de História da Ciência, de Documentação e Arquivo, de Museologia, e de

\footnotetext{
${ }^{45}$ Para descrever o MAST, Martins (2011) utilizou o trabalho de pesquisa de mestrado de Cazelli (1992), que investigou o processo de criação do Museu.
} 
Educação em Ciências (COEDU ${ }^{46}$ ). A COEDU cumpre o papel de setor educativo e é a coordenação onde estão lotados os educadores do Museu. A equipe da COEDU é interdisciplinar e conta com a participação de educadores desde o início do seu projeto, construindo "uma forte perspectiva institucional voltada para educação/divulgação da ciência" (MARTINS, 2011, p. 197). Há também a presença de um forte viés voltado para a pesquisa em História da Ciência, a partir do grupo oriundo do Observatório Nacional.

De acordo com a autora, essas áreas têm tensões que vêm desde a equipe constitutiva do MAST, que, como já destacado anteriormente, é uma instituição que têm como sua missão explicitada a vocação educacional, mas também a de produção de conhecimento sobre História da Ciência e de cuidado e pesquisa sobre o acervo de instrumentos científicos do Observatório Nacional. As equipes responsáveis por cada área, além de assumir suas funções, estariam também preocupadas em "garantir seu espaço em termos de importância e visibilidade dentro da instituição" (MARTINS, 2011, p. 197).

Em relação aos visitantes, como já assinalado, o público principal do Museu é o escolar, mas também são desenvolvidas várias ações para atrair o público espontâneo, sendo meta da COEDU projetar o Museu como opção de lazer, cultura e educação na Zona Norte carioca, ampliando os tipos de público que frequentam o Museu (MARTINS, 2011). Além disso, nas últimas duas décadas, têm sido desenvolvidas ações para o público de visitação estimulada, englobando grupos reunidos por lideranças comunitárias, estudantes de escolas públicas, e pessoas da terceira idade (incluindo seus familiares), oriundos de comunidades das Zonas Norte, Oeste, Sul e de municípios da Baixada Fluminense. Essas visitas têm sido acompanhadas de investigação sobre as possibilidades de inclusão social e empoderamento dos sujeitos a partir das atividades desenvolvidas (CAZELLI et al., 2015).

46 Optou-se por usar, neste trabalho, a sigla COEDU, que é a sigla que consta no site oficial da instituição <www.mast.br> (Acesso em: 14 out. 2017). Os trabalhos de referência dessa seção utilizam siglas diferentes para a Coordenação de Educação em Ciências (CEC em Martins (2011) e CED em Cazelli et al. (2015)). 


\subsection{4. \\ O Espaço COPPE Miguel Simoni}

O Espaço COPPE foi criado em 1996 com o nome de Museu Tecnológico da COPPE (MUTEC) pelo então diretor do Instituto Alberto Luiz Coimbra de Pós-graduação e Pesquisa de Engenharia da UFRJ (COPPE/UFRJ). O Museu passou a ter apoio da Fundação VITAE ${ }^{47}$ em 1999, quando começou a elaborar cursos de formação continuada para professores e alunos de ensino médio (GONÇALVES e VERGARA, 2012) ${ }^{48}$. Em 2002, o MUTEC passou a se chamar Espaço COPPE Miguel de Simoni ${ }^{49}$, quando foi também aberto ao público. O Espaço COPPE está localizado no Centro de Tecnologia da Cidade Universitária da UFRJ, Zona Norte do Rio de Janeiro (Figura 7).

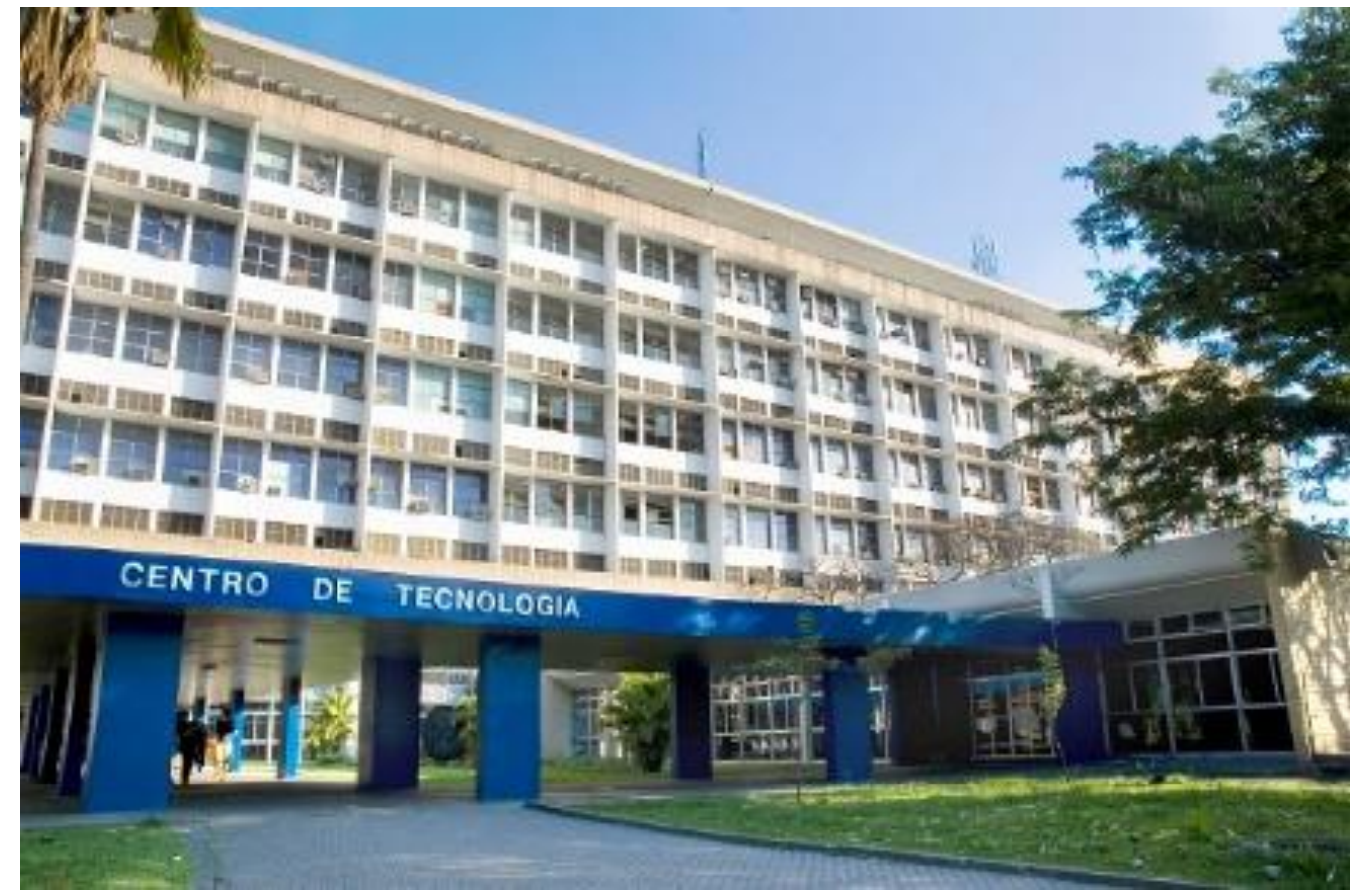

Figura 7: Foto da fachada do Centro de Tecnologia da UFRJ onde está localizada a COPPE. Fonte: <http://www.adufrj.org.br/wp-content/uploads/2017/10/CT.jpg>.

Acesso em: 17 dez. 2017.

${ }^{47}$ A Fundação VITAE fomentou projetos ligados à arte, cultura e divulgação da ciência no Brasil, por meio de financiamento a programas, projetos e bolsas de trabalho e de pesquisa, entre os anos de 1985 e 2005 (ALMEIDA e HERENCIA, 2012).

48 Gonçalves e Vergara (2012) fazem uma discussão sobre os sentidos da mudança do nome de "museu" para "espaço". Essa discussão segue a linha adotada neste trabalho, no sentido que considera que os centros de ciência, a partir da definição de museus da ICOM, são também espaços museológicos.

49 Miguel Simoni foi professor da COPPE/UFRJ. 
Em 2006, foi inaugurada uma exposição permanente, situada no Centro de Tecnologia da UFRJ, e dividida nos seguintes eixos temáticos: Mecanismos e Organismos; Sociedade e Meio Ambiente; Informação e Conhecimento; Trabalho, Serviços e Entretenimento; Matéria e Energia e Mundo Virtual (GONÇALVES e VERGARA, 2012) (Figura 8). Em 2016 foi inaugurada uma nova exposição permanente chamada "Exploradores do Conhecimento"50.

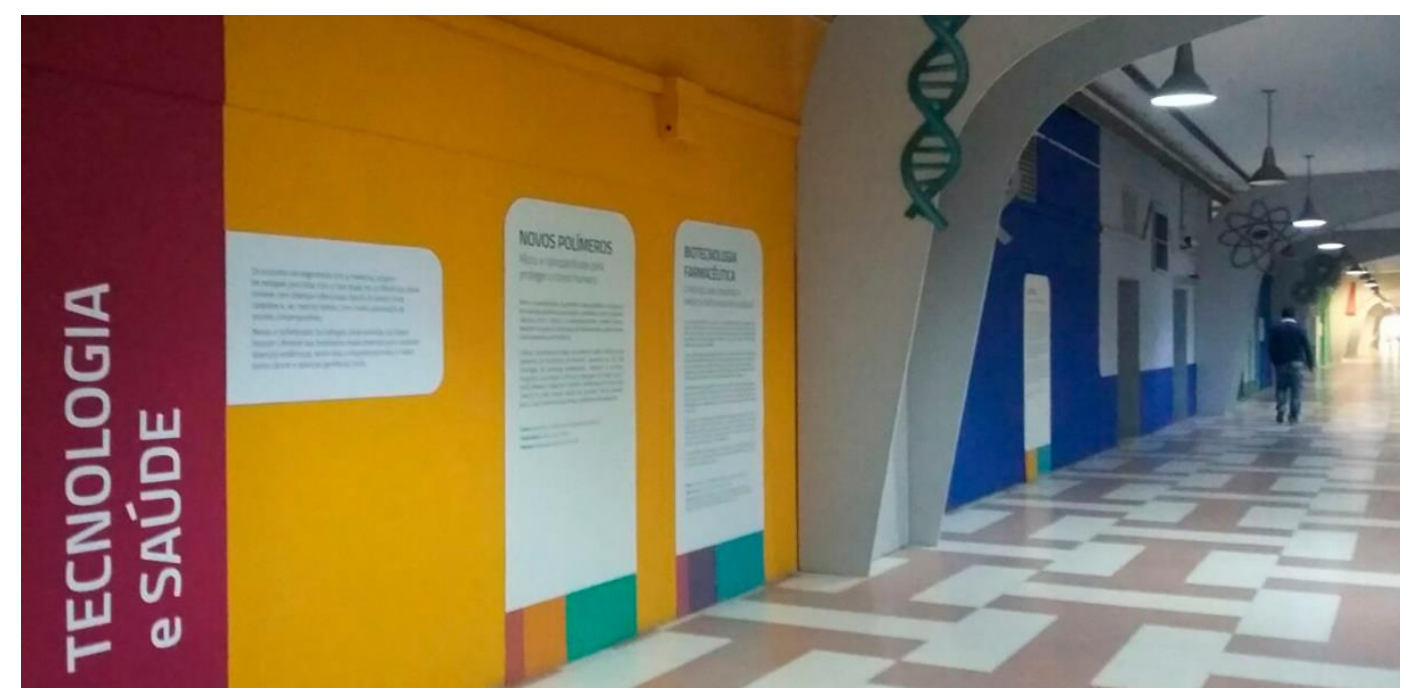

Figura 8: Foto de parte da exposição permanente do Espaço COPPE.

Fonte: <http://www.espaco.coppe.ufrj.br/wp-content/uploads/2016/09/DSC0074-1300x199.jpg>. Acesso em: 17 dez. 2017.

Hoje, o público alvo do espaço são os alunos de ensino médio e do segundo segmento do ensino fundamental. As visitas acontecem apenas com grupos agendados e acompanhadas por mediadores.

\subsection{5. \\ O Museu da Vida}

O Museu da Vida foi fundado em 1999 e está localizado no campus de Manguinhos da Fundação Oswaldo Cruz (Fiocruz), Zona Norte da cidade do Rio de Janeiro. Institucionalmente o Museu é um departamento da Casa de Oswaldo Cruz (COC) e está situado em diferentes áreas temáticas em locais distintos do campus, como o "Espaço Passado e

50 Informação retirada do sítio eletrônico <http://www.espaco.coppe.ufrj.br>. Acesso em: 21 out. 2017. 
Presente" no Castelo Mourisco (Figura 9), o "Espaço da Biodescoberta", o "Espaço Ciência em Cena" e o "Parque da Ciência" (Figura 10). ${ }^{51}$

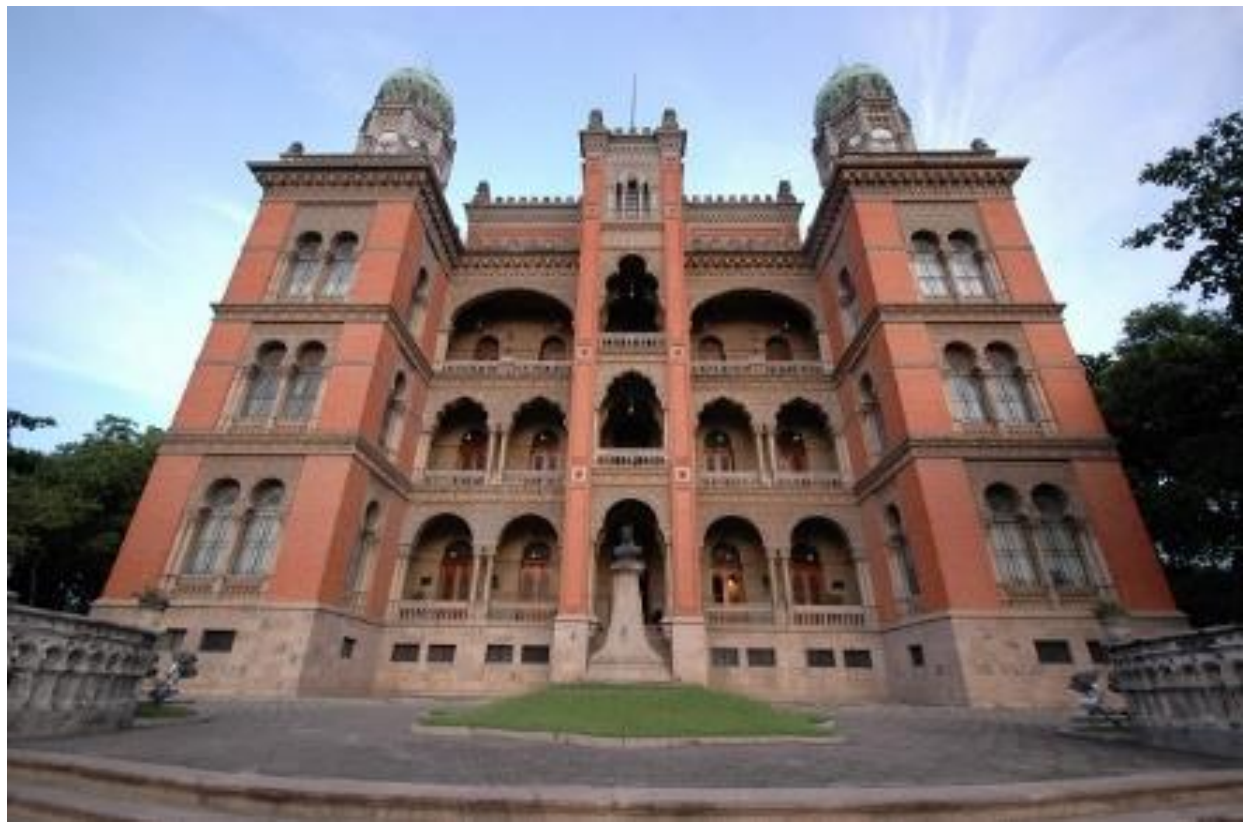

Figura 9: Foto da fachada do Castelo Mourisco da Fiocruz. Fonte:

<http://www.museudavida.fiocruz.br/index.php/area-de-visitacao/castelo-mourisco>. Acesso em: 17 dez. 2017.

É importante lembrar que, mesmo antes da criação do Museu da Vida, a Fiocruz já abrigava espaços museológicos. Desde a concepção do Castelo Mourisco já se idealizava a inclusão de um museu em seu interior, e hoje o prédio ainda abriga coleções que inicialmente eram destinadas apenas à comunidade científica. A partir da década de 1970, a visitação passa a ser aberta, embora de forma limitada, mas a ideia de um campus aberto à sociedade ainda não fazia parte das intenções da instituição (BEVILAQUA, 2017).

A preservação da memória da Fiocruz passou a ser responsabilidade da COC a partir de sua criação em 1986, assumindo também o papel de unidade responsável pelas ações educativas e de divulgação da ciência. De acordo com Bevilaqua (2017), foi nesse contexto que surgiu o Museu da Casa de Oswaldo Cruz, com função de apresentar a história da instituição ao público. Durante a década de 1980 até o início da década de 1990, a COC organizou exposições em diversos locais da cidade, com uma

\footnotetext{
${ }^{51}$ Para mais informações sobre os espaços e fotos, consultar Seibel-Machado (2009) e o endereço eletrônico <http://www.museudavida.fiocruz.br/index.php/visitacao > Acesso em: 17 dez. 2017.
} 
divulgação da ciência feita dentro de uma perspectiva histórica e cultural. A partir da década de 1990, teve início a elaboração do projeto do Museu da Vida.

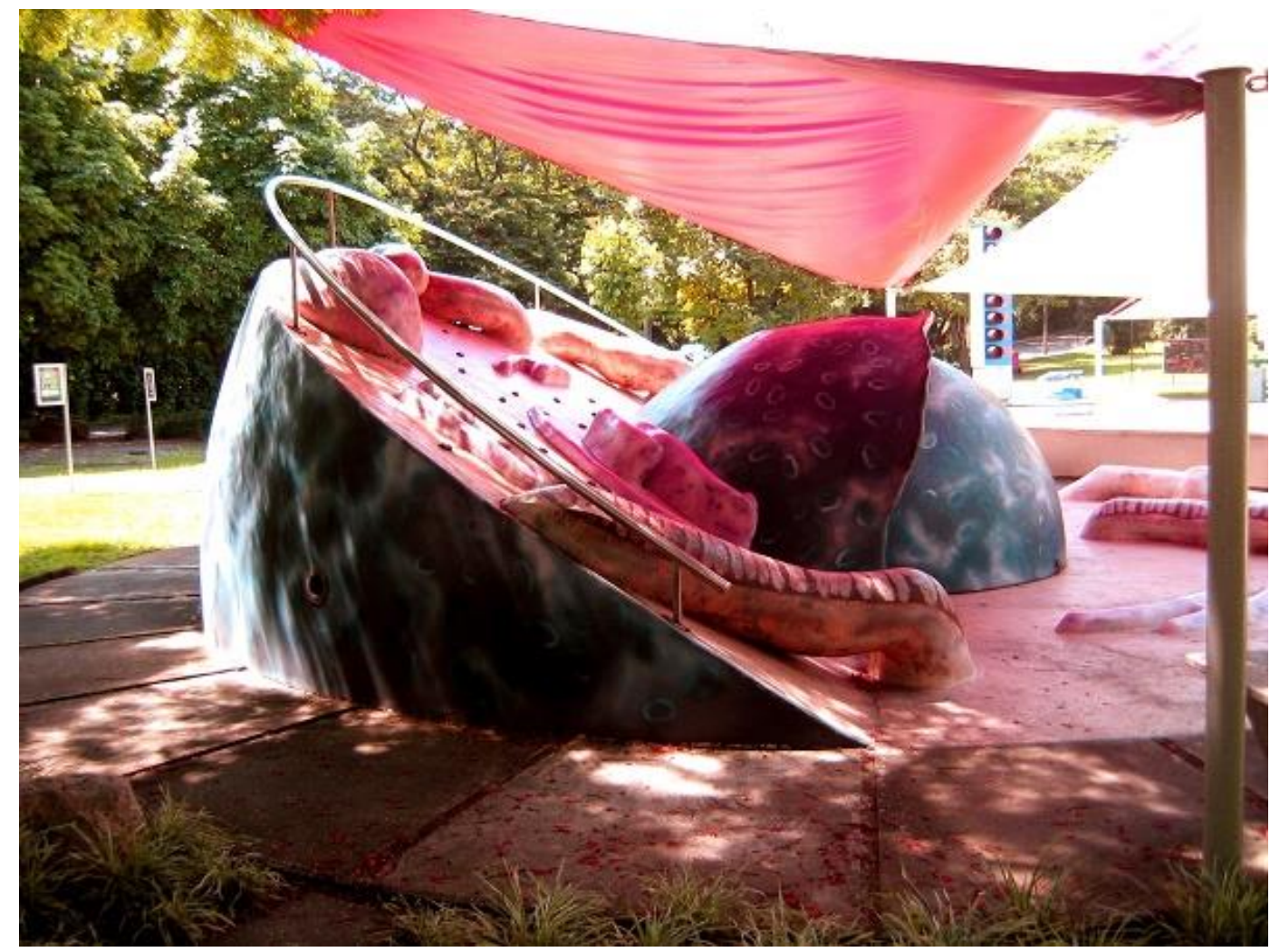

Figura 10: Foto de modelo de célula localizado no espaço Parque da Ciência do Museu da Vida. Fonte: < http://www.museudavida.fiocruz.br/index.php/area-devisitacao/parque-da-ciencia>. Acesso em: 17 dez. 2017.

A criação do Museu ocorreu dentro do contexto do surgimento dos demais museus e centros de ciência no Brasil nas décadas de 1980-90 (museus de terceira geração com perspectivas construtivistas). A sua proposta teve influências de uma concepção de museu interativo e dinâmico, referenciada por museus de ciência como o Exploratorium em São Francisco (EUA) e o La Villete em Paris (França). Além dessas concepções, o Museu incorporou as experiências acumuladas no trabalho já desenvolvido pela $\mathrm{COC} /$ /Fiocruz ligado à preservação da memória, desenvolvimento cultural, à popularização e educação em ciências e saúde (SEIBEL-MACHADO, 2009).

Assim, a identidade institucional do Museu da Vida é a de uma instituição de alfabetização, divulgação e educação em ciências, mas com 
a especificidade de também dialogar com a história das ciências e com as ciências da saúde (SEIBEL-MACHADO, 2009).

De acordo com a autora, uma das medidas organizacionais adotadas foi a criação de equipes e gerências específicas para cada área temática, que seriam então responsáveis pelo desenvolvimento, execução e acompanhamento das exposições e demais atividades, seguindo um modelo de equipes multidisciplinares que dialogassem entre si. Dentro desse formato, o Museu tem também um Serviço de Educação em Ciências e Saúde, que cumpre a função de setor educativo, além de um Centro de Recepção, o Centro de Criação e a Museologia.

A proposta inicial indica que os públicos-alvo seriam a população em geral, os estudantes e professores da educação básica, estudantes de graduação e a comunidade científica, mas a prioridade é dada ao público escolar.

O desenvolvimento de ações culturais e de divulgação da ciência nas comunidades da região também é uma das marcas do Museu. São concebidas ações específicas para públicos historicamente excluídos, buscando-se mudar a lógica de escassez de acesso à cultura, à educação e à ciência. Destacam-se as ações destinadas aos jovens dos territórios no entorno do Museu, como o Curso de Formação de Monitores que ocorreu entre 1999 e 2011 (BEVILAQUA et al., 2017).

\subsection{6.}

\section{O Museu da Química Athos da Silveira Ramos}

O Museu da Química Athos da Silveira Ramos ${ }^{52}$ foi criado em 2001, durante a 9a Semana da Química da UFRJ. De acordo com Afonso e Santos (2009), o Museu é uma iniciativa pioneira pois é o único museu dedicado à Química no país, tendo o objetivo de preservar o passado histórico dessa área do conhecimento no Brasil, e principalmente na cidade

52 O nome do Museu é uma homenagem ao Professor Athos da Silveira Ramos (19062002), que desempenhou importante papel na criação do Instituto de Química da UFRJ, inaugurado em 1959. O Professor Athos esteve presente na exposição inaugural em 2001 (HANDFAS, GRANATO e LOURENÇO, 2016). 
do Rio de Janeiro. Seu acervo está exposto em uma sala do Instituto de Química localizado no Centro de Tecnologia da UFRJ.

O projeto de criação do Museu teve início em 1997 por iniciativa de um professor do departamento de Química Analítica da Universidade, designado para compor uma comissão que iria decidir a destinação de uma grande quantidade de material patrimoniado que seria descartado para que houvesse espaço para a instalação de novos equipamentos. $O$ encontro de uma peça que pertenceu a $\mathrm{D}$. Pedro II teria chamado atenção para o valor das peças que compunham esse patrimônio (HANDFAS, GRANATO e LOURENÇO, 2016).

Segundo os autores, a partir do acervo selecionado foi organizada uma exposição sobre a história da Química Experimental no século XX durante a Semana da Química. Essa primeira exposição marcou a criação do Museu, cadastrado como o primeiro projeto de extensão do Instituto de Química na Pró Reitoria de Extensão da UFRJ, e possibilitou a solicitação de bolsas e financiamento a partir de editais e agências de fomento.

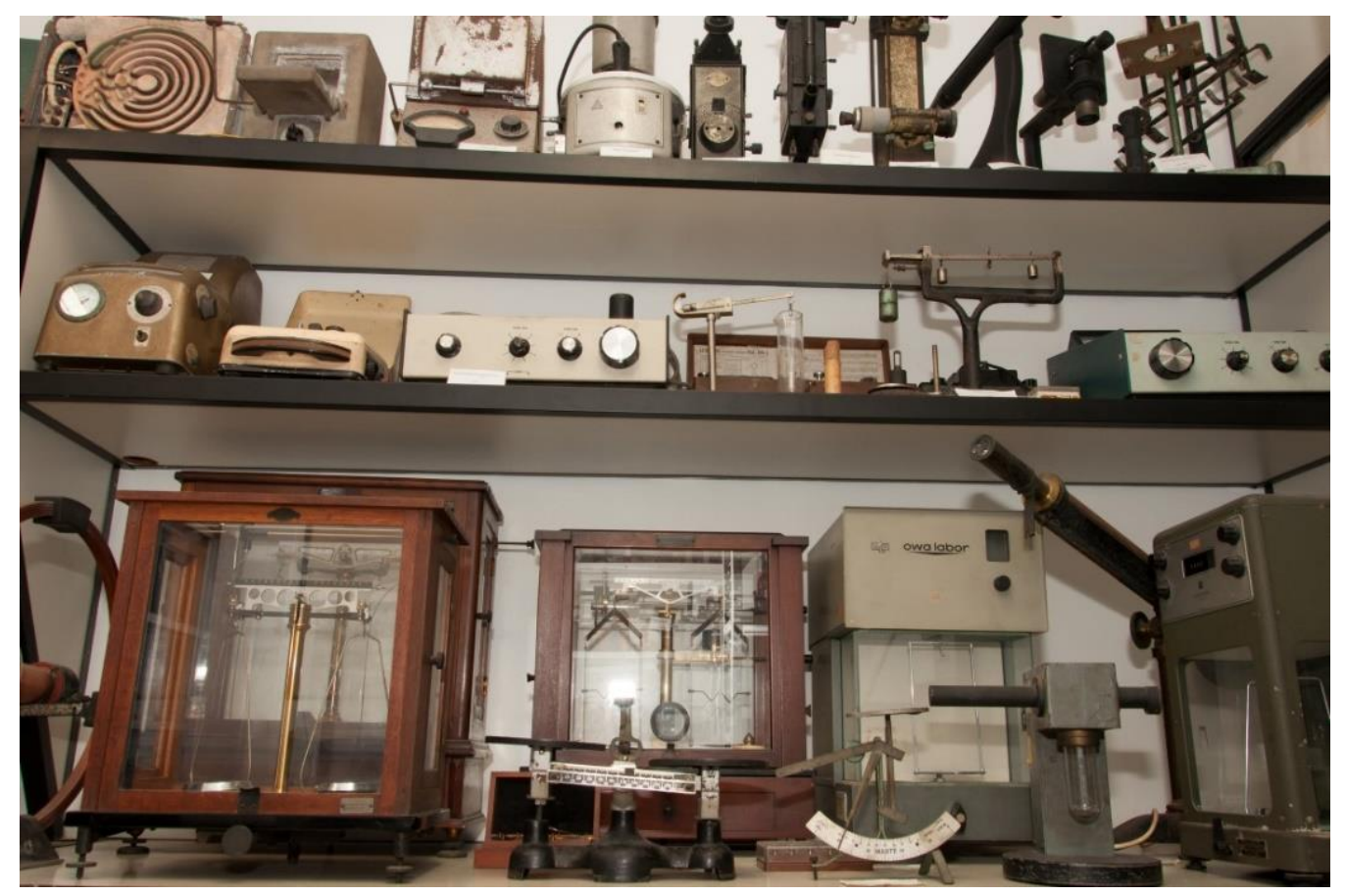

Figura 11: Foto de parte do acervo do Museu da Química. Fonte:

<https://www.iq.ufrj.br/museu/>. Acesso em: 17 dez. 2017.

Hadfas e colaboradores (2016) destacam que o Museu da Química se insere em um grupo de museus de ciência da UFRJ, criados a partir da preocupação de professores com a memória e história de algumas 
unidades. São espaços quase sempre ligados aos departamentos e institutos aos quais estão subordinados e que, em sua maior parte, se constituem como projetos de extensão dedicados à divulgação da ciência. Essas atividades garantem visibilidade e asseguram a possibilidade do vínculo de bolsistas para a realização de tarefas e estudos relacionados aos objetos, acervos e coleções.

Atualmente o Museu da Química possui um amplo acervo de peças e documentos acerca da história da UFRJ e uma biblioteca de obras raras. A visitação ocorre por meio de visitas guiadas de escolas e de grupos da própria universidade. São também realizadas exposições itinerantes com parte do acervo. Além das exposições, esse acervo tem servido como fonte de pesquisa para alunos de graduação e pós-graduação dos cursos de Química e Engenharia Química (AFONSO e SANTOS, 2009).

\section{2.}

\section{O perfil dos profissionais entrevistados}

Conforme destacado anteriormente, foram realizadas entrevistas com os responsáveis pelos bolsistas de iniciação científica dos seis museus de ciências da cidade do Rio de Janeiro que declararam possuir esse tipo de bolsa em seus quadros. Cabe destacar que em cinco museus foram realizadas entrevistas com dois profissionais, e no Museu da Química Athos da Silveira Ramos foi realizada uma entrevista. A seguir, apresento algumas informações sobre os entrevistados para que o leitor possa ter um panorama desse grupo de profissionais.

O perfil dos entrevistados, do ponto de vista da formação, do tempo em que atuam na instituição e do vínculo empregatício, é muito diverso (Quadro 2). De uma forma geral, é possível afirmar que em sua maioria são pessoas que têm experiência com o trabalho em museus, seja pelo tempo de atuação em suas instituições ou por experiências prévias. Há pessoas que trabalham nas instituições desde a sua origem, como Antônio e Fernando53 (Museu da Química e Espaço COPPE, respectivamente).

53 Os nomes dos entrevistados são fictícios com o intuito de preservar a identidade, e foram escolhidos de modo aleatório. 
Quadro 2: Perfil dos funcionários responsáveis pelos alunos bolsistas de IC nos museus de ciência da cidade do Rio de Janeiro

\begin{tabular}{|c|c|c|c|c|c|}
\hline Instituição & Entrevistado & Vínculo & Cargo & $\begin{array}{l}\text { Tempo de } \\
\text { Trabalho }\end{array}$ & Formação \\
\hline \multirow[t]{2}{*}{ Museu Nacional } & Anita & $\begin{array}{l}\text { Servidora } \\
\text { Pública }\end{array}$ & $\begin{array}{l}\text { Técnica em Assuntos Educacionais } \\
\text { Chefe da Seção de Assistência ao } \\
\text { Ensino }\end{array}$ & $\begin{array}{l}5 \text { anos } \\
3 \text { meses }\end{array}$ & $\begin{array}{l}\text { Licenciada em História } \\
\text { Mestre em Educação } \\
\text { Doutoranda em Educação }\end{array}$ \\
\hline & Graziela & $\begin{array}{l}\text { Servidora } \\
\text { Pública }\end{array}$ & Professora Titular & 27 anos & $\begin{array}{l}\text { História Natural } \\
\text { Mestrado em Botânica } \\
\text { Doutorado em Botânica }\end{array}$ \\
\hline \multirow[t]{2}{*}{$\begin{array}{l}\text { Espaço } \\
\text { Ciência Viva }\end{array}$} & Ludmila & Bolsista & $\begin{array}{l}\text { Produtora Cultural } \\
\text { Mediadora Sênior }\end{array}$ & 5 anos & $\begin{array}{l}\text { Produtora Cultural } \\
\text { Mestrado em Ensino de Ciências } \\
\text { Doutoranda em Ensino de Ciências }\end{array}$ \\
\hline & Fernando & Voluntário & Coordenador de Matemática e Física & 33 anos & Físico \\
\hline \multirow[t]{2}{*}{ MAST } & Mauro & $\begin{array}{l}\text { Servidor } \\
\text { Público }\end{array}$ & $\begin{array}{l}\text { Pesquisador Titular } \\
\text { Coordenador de Iniciação Científica }\end{array}$ & 27 anos & $\begin{array}{l}\text { Licenciado em Letras } \\
\text { Mestrado em Linguística } \\
\text { Doutorado em Linguística } \\
\text { Pós-doutorado em História da Ciência }\end{array}$ \\
\hline & César & $\begin{array}{l}\text { Cargo } \\
\text { Comissionado }\end{array}$ & Coordenador do Setor Educativo & 6 anos & $\begin{array}{l}\text { Bacharelado e Licenciatura em Física } \\
\text { Mestrado em Astronomia } \\
\text { Doutorado em Geofísica }\end{array}$ \\
\hline \multirow[t]{2}{*}{ Espaço COPPE } & Ruth & $\begin{array}{l}\text { Servidora } \\
\text { Pública }\end{array}$ & Coordenadora Executiva & $\begin{array}{l}2 \text { anos e } \\
\text { meio }\end{array}$ & $\begin{array}{l}\text { Matemática } \\
\text { Pós-graduada em Gestão e Produção } \\
\text { Cultural }\end{array}$ \\
\hline & Alberto & $\begin{array}{l}\text { Servidor } \\
\text { Público }\end{array}$ & Coordenador de Experimentos & 10 anos & $\begin{array}{l}\text { Licenciado em Física } \\
\text { Mestre em Ensino de Física }\end{array}$ \\
\hline \multirow[t]{2}{*}{ Museu da Vida } & Eric & $\begin{array}{l}\text { Servidor } \\
\text { Público }\end{array}$ & $\begin{array}{l}\text { Coordenador do programa de iniciação } \\
\text { a divulgação e popularização da Ciência }\end{array}$ & 9 anos & $\begin{array}{l}\text { Historiador } \\
\text { Administrador } \\
\text { Mestre em Educação em Ciências }\end{array}$ \\
\hline & Marina & $\begin{array}{l}\text { Funcionária } \\
\text { Terceirizada }\end{array}$ & $\begin{array}{l}\text { Supervisora Pedagógica do Programa } \\
\text { de iniciação à Produção Cultural }\end{array}$ & 5 anos & Pedagoga \\
\hline $\begin{array}{l}\text { Museu da } \\
\text { Química }\end{array}$ & Antônio & $\begin{array}{l}\text { Servidor } \\
\text { Público }\end{array}$ & Professor Titular & $\begin{array}{l}15 \text { anos } \\
\text { (no museu) }\end{array}$ & $\begin{array}{l}\text { Engenheiro Químico } \\
\text { Química com Produções Tecnológicas }\end{array}$ \\
\hline
\end{tabular}

Fonte: Dados da Pesquisa 
Há casos como o de Eric (Museu da Vida) e César (MAST) que começaram como alunos bolsistas e retornaram como funcionários. Mauro (MAST) e Ludmila (ECV) atuaram em outros museus antes de ocuparem os cargos atuais em suas respectivas instituições.

Em relação ao vínculo, foi possível constatar que a maioria é composta por servidores públicos, com exceção da Marina (Museu da Vida), que é funcionária terceirizada, de César (MAST), que possui um cargo comissionado e Ludmila (ECV) que é bolsista. Fernando é servidor do Museu da Vida, mas atua também no ECV como voluntário.

A formação desses profissionais é bastante diversificada, havendo um predomínio de pessoas com graduação em cursos na área de ciências da natureza (Física, Química, Biologia) e Matemática. Chama atenção o fato de que a maior parte declarou ter uma formação em nível de pósgraduação. Sete entrevistados possuem mestrado, sendo que quatro (Anita, Ludmila, Eric e Alberto) desenvolveram suas pesquisas na área de Educação e Ensino de Ciências. Cinco são doutores ou estão em processo de doutoramento ${ }^{54}$.

\section{3.}

\section{Os tipos de bolsas}

A primeira surpresa a partir das entrevistas é que, de acordo com o que afirmam os entrevistados, nem todos os museus que responderam no questionário ter em seus quadros bolsistas de IC, de fato possuem. Esses dados são confrontados no Quadro 3.

As respostas das entrevistas foram coerentes com os dados obtidos a partir do questionário para o Museu Nacional e o MAST. O Museu Nacional possui bolsistas de graduação com bolsas PIBIC e balcão, além de alunos que fazem estágio de IC voluntário (sem receber nenhum tipo de bolsa). Há também alunos de ensino médio que participam do Programa de Iniciação Científica em parceria com o Colégio Pedro II (PIC Jr.).

\footnotetext{
${ }^{54}$ A pergunta feita foi: "Qual a sua formação?". É possível que alguns entrevistados não tenham declarado todo seu itinerário formativo, omitindo a formação em pós-graduação. Um exemplo é Antônio, que só indicou sua formação na graduação, mas sendo professor titular da UFRJ, muito provavelmente possui título de doutor.
} 
Quadro 3: Divergência de respostas sobre a presença de bolsistas de IC (ensino médio e graduação) nos questionários e entrevistas

\begin{tabular}{|l|c|c|c|c|}
\hline Questão & \multicolumn{4}{|l|}{ O museu possui alunos bolsistas de Iniciação Científica? } \\
\hline Instrumento & Questionário & \multicolumn{1}{l|}{ Entrevista } \\
\hline Instituição/Segmento & Ensino Médio & Graduação & Ensino Médio & Graduação \\
\hline Museu Nacional & Sim & Sim & Sim & Sim \\
\hline Espaço Ciência Viva & Não & Sim & Não & Sim \\
\hline MAST & Não & Sim & Não & Sim \\
\hline Espaço COPPE & Sim & Sim & Não & Não \\
\hline Museu da Vida & $\begin{array}{c}\text { Sim } \\
\text { (eventualmente) }\end{array}$ & Não & Não & Não \\
\hline Museu da Química & Sim & Sim & Não & Não \\
\hline
\end{tabular}

Fonte: Dados da Pesquisa

Os alunos do PIC Jr. podem ser bolsistas do programa Jovens Talentos da FAPERJ (PJTC) ou voluntários, realizando estágio em diferentes setores do Museu, incluindo o setor educativo - responsável pela distribuição e acompanhamento dos alunos de ensino médio. O setor educativo não possui bolsistas de IC de graduação, mas já teve alunos com bolsas do Programa Institucional de Bolsas de Extensão (PIBEX). Atualmente o setor tem bolsistas do Programa de Desenvolvimento Institucional (PDI). Em ambos os casos, os bolsistas são necessariamente alunos de graduação da própria UFRJ, pois ambos os programas são desenvolvidos pela universidade.

O MAST possui bolsistas PIBIC em todos os seus setores e eventualmente estagiários voluntários. Também há alunos de ensino médio e pesquisa que recebem bolsas do Centro de Integração Empresa-Escola $(\mathrm{CIEE})^{55}$.

No Museu da Vida, a ida a campo revelou que o museu já teve bolsistas de IC da FAPERJ, mas atualmente todos os bolsistas de graduação recebem uma bolsa vinculada a um programa de iniciação próprio deste museu. Quando o Museu foi criado, recebia alunos de IC de pesquisadores ligados à Casa de Oswaldo Cruz (COC/Fiocruz), além de alunos de IC de pesquisadores do próprio museu. Nesse primeiro momento, o Museu teve apoio de pesquisadores dos outros departamentos da Fiocruz para receber alunos bolsistas que, segundo Eric, 'teriam uma

${ }^{55}$ Centro de Integração Empresa-Escola (CIEE) é uma Organização Não-Governamental mantida por empresários, com o objetivo possibilitar a realização de estágio profissional para alunos de ensino médio, técnico ou superior. Mais informações em <http://www.ciee.org.br>. Acesso em: 05 dez. 2017. 
vivência e pesquisas voltadas para a área de divulgação e mediação em museus". Conforme já ressaltado, esses alunos recebiam bolsas da FAPERJ. O próprio Eric revelou que, à época, foi um desses bolsistas (1999/2000). Até 2010, não havia um programa de formação de alunos de graduação no museu, e essa formação acontecia a partir de iniciativas pontuais de alguns pesquisadores. Em 2011, foi criado um programa de apoio à divulgação científica, o que, nas palavras de Eric, foi feito "para oportunizar a vivência de jovens universitários em ações de mediação em museu". Nesse momento o foco da formação dos bolsistas passa a ser a divulgação científica. Em 2013, por uma iniciativa do museu, juntamente com a direção da unidade, o programa foi reformulado, passando a ser chamado de Programa de Iniciação à Divulgação Científica e Popularização da Ciência (PROPOP) porque entendeu-se que o "o nome anterior não dava conta do que o programa fazia". Além disso, segundo Eric, as mudanças da estrutura e no nome fez com que o programa ficasse mais alinhado a outros programas de iniciação para alunos de graduação da Fiocruz. Portanto, o Museu da Vida se destaca por possuir um programa de iniciação próprio, relacionado aos saberes da divulgação e popularização da ciência.

Ainda com relação ao Museu da Vida, não há uma formação de iniciação científica para os alunos de ensino médio: eles fazem parte de um Programa de Iniciação à Produção Cultural (Pró-Cultural), desenvolvido desde 2012 e destinado a alunos das escolas estaduais dos territórios do entorno do Museu e tem como objetivo a formação de produtores culturais, com ênfase em divulgação científica. Para participar do curso de formação, os alunos recebem uma bolsa e após a formação alguns continuam como bolsistas de apoio técnico no próprio museu.

O Museu da Química, que também é ligado à UFRJ, já teve alunos bolsistas do PIBIC, mas ao contrário do que foi respondido no questionário, atualmente possui alunos bolsistas de extensão universitária. De acordo com Antônio:

Nos primeiros 5 anos eu tive um misto de alunos de extensão, a chamada bolsa PIBEX, Programa Institucional de Bolsas de Extensão e bolsas de apoio estudantil, para alunos do alojamento, que recebiam uma bolsa até generosa, mas que tinham em contrapartida que atuar em algum projeto de 
pesquisa ou de extensão. Então alguns escolheram o Museu justamente como uma opção para poder manter o direito à bolsa. A partir de 2006, se não me engano, essa exigência foi descontinuada, então tinha a bolsa e pronto, e eu só passei a ter alunos de extensão até 2009, quando nesse ano e em 2010 eu tive alunos PIBIC que fizeram um projeto, não de extensão, mas de pesquisa histórica com esse mesmo acervo. De 2011 para cá, até o momento, aí sim, só alunos de extensão. Então você vê, tem uma certa flutuação conforme as oportunidades que aparecem. - Antônio

Assim como explicitado em relação aos bolsistas de extensão do Museu Nacional, essas bolsas são fornecidas a partir de editais dos programas de apoio estudantil e de extensão e restringem a participação a alunos da própria universidade.

O Espaço COPPE foi o que teve maior discrepância entre o que foi respondido no questionário e o que foi relatado nas entrevistas. No questionário, foi indicado que o museu tinha alunos de IC de graduação e ensino médio. Entretanto, a partir das entrevistas, foi possível constatar que ele contava com bolsistas de extensão universitária, que, como no caso dos museus do Museu Nacional e do Museu da Química, também tinham que ser alunos de graduação da própria UFRJ. Não há ou houve trabalho de formação de IC, ou de qualquer outro tipo com alunos bolsistas de ensino médio.

Em resposta ao questionário, foi indicado que Espaço Ciência Viva possuía bolsistas de IC de graduação. Porém, não ficou claro na fala dos entrevistados se os alunos são bolsistas de iniciação científica ou de extensão. Na verdade, os entrevistados parecem se contradizer. Cabe aqui lembrar que esse museu é uma ONG dirigida basicamente por professores também da UFRJ. Na fala de Ludmila, esses professores conseguem as bolsas

[...] por meio de bolsas de extensão da universidade e de agências de fomento. E aí eles mandam esses alunos para cá [para o ECV], porque nossos alunos são todos ou bolsistas da UFRJ, ou de algum projeto vinculado à universidade. [...] quase a totalidade de bolsas que a gente tem hoje são fruto dessa ação e os nossos bolsistas, ou são bolsistas de extensão [da universidade], ou são bolsas conseguidas através de projetos específicos junto à FAPERJ, CNPq. - Ludmila

Não fica claro se essas bolsas são bolsas balcão de IC ou se são bolsas de projetos de extensão encaminhados a essas agências de fomento. Segundo a entrevistada, há também os alunos que fazem o estágio de forma voluntária no museu. 
Já de acordo com Fernando, também do Espaço Ciência Viva, os alunos são

principalmente bolsistas de iniciação científica, até porque essa galera que a gente orienta, eles têm que fazer uma pesquisa, que normalmente é o desenvolvimento de um módulo interativo ou avaliação de algum módulo interativo e, ao mesmo tempo, ele atua também na mediação das crianças das escolas.- Fernando

Sobre os alunos de ensino médio, pela fala de Ludmila, o museu já teve bolsistas Jovens Talentos da FAPERJ. Essas bolsas também eram distribuídas a alunos do Colégio Pedro II e atualmente há um trabalho restrito a um grupo de alunos do IFRJ, devido à presença de um professor voluntário oriundo dessa instituição.

Os tipos de bolsa existentes atualmente em cada uma das instituições investigadas estão indicados no Quadro 4. O descompasso que algumas instituições apresentaram, entre o que foi respondido no questionário e o que foi dito pelos entrevistados, fez que eu buscasse entender como se dava o trabalho formativo que era desenvolvido com os bolsistas em geral. Será que a natureza da bolsa determinava o tipo de trabalho realizado? Será que mesmo com o aluno tendo uma bolsa de extensão universitária (ou de outra natureza), ele desenvolvia atividades de iniciação científica? Desta forma, fiz a opção por manter a análise sobre as atividades formativas desses alunos bolsistas ou voluntários em todas as seis instituições.

Quadro 4: Tipos de bolsas presentes nas instituições pesquisadas

\begin{tabular}{|l|l|l|}
\hline Instituição/Segmento & Ensino Médio & Graduação \\
\hline Museu Nacional & PJTC/FAPERJ & $\begin{array}{l}\text { Bolsas Balcão } \\
\text { PIBIC } \\
\text { PIBEX/UFRJ } \\
\text { PDI/UFRJ } \\
\text { Estágio Voluntário }\end{array}$ \\
\hline Estágio Voluntário & $\begin{array}{l}\text { Extensão } \\
\text { Iniciação Científica } \\
\text { Estágio Voluntário }\end{array}$ \\
\hline MAST & Não possuem & $\begin{array}{l}\text { PIBIC } \\
\text { CIEE }\end{array}$ \\
\hline Espaço COPPE & CIEE & Extensão \\
\hline Museu da Vida & Não possuem & PROPOP \\
\hline Museu da Química & Pró-Cultural & PIBEX/UFRJ \\
\hline
\end{tabular}

Fonte: Dados da Pesquisa

É importante considerar que os tipos de bolsas ofertadas por esses espaços podem ter variado ao longo dos anos e que as informações aqui descritas se basearam no que foi relatado pelos entrevistados. De qualquer 
forma, chama a atenção a diversidade de tipos de bolsas e sua variação ao longo do tempo.

5.4.

\section{Atividades desenvolvidas pelos alunos bolsistas}

Como um dos objetivos iniciais do trabalho era caracterizar e compreender a natureza das atividades pelos bolsistas de IC nos museus de ciência da cidade do Rio de Janeiro, como já explicado na metodologia, a escolha dos critérios investigados nas entrevistas se baseou no que 0 CNPq determina como atributos do programa PIBIC (BRASIL. CNPq, 2006) e nos trabalhos de Massi e Queiroz sobre as pesquisas relacionadas à IC no país (MASSI e QUEIROZ, 2010; 2015).

De acordo com a resolução normativa n 17/2006 do CNPq, compete a cada Instituição de Ensino Superior (IES) ou Instituto de Pesquisa (IPq) administrar as cotas de bolsas e a sua distribuição aos pesquisadores e/ou alunos. As IES e IPq também devem promover eventos onde os bolsistas deverão apresentar sua produção na forma de resumos, pôsteres e apresentações orais, cabendo a um comitê institucional destinado ao PIBIC avaliar o desempenho desses alunos, convidando inclusive avaliadores externos.

Assim, na tentativa de investigar os processos formativos dos bolsistas nos museus selecionados, buscou-se, com a realização das entrevistas, compreender os processos formativos a partir dos critérios de seleção, das atividades atribuídas a esses alunos, da apresentação dos resultados do processo (caso ocorresse), dos mecanismos de avaliação (por parte da instituição e dos próprios alunos) adotados por cada museu.

Esses atributos foram avaliados independentemente das bolsas ofertadas serem de iniciação científica, extensão, ou outras, na tentativa de entender, inclusive, se a natureza da bolsa determina a formação dos alunos. Os resultados são descritos nas seções seguintes.

\subsection{1. Os processos seletivos}

No que se refere à seleção de alunos bolsistas $\mathrm{PIBIC}$, a resolução normativa $n^{\circ}$ 17/06 determina que cada instituição deve estabelecer as 
regras de seleção dos alunos e que esta deve ser amplamente divulgada e constar em edital público (BRASIL. CNPq, 2006).

A análise das entrevistas permitiu perceber que cada instituição define seus critérios de seleção, mas há pontos em comum e também distintos, conforme será apresentado a seguir.

No Museu Nacional, o processo seletivo varia de acordo com o tipo de bolsa oferecida. Em relação aos bolsistas de IC (PIBIC ou balcão), cabe a cada orientador decidir os critérios para selecionar os alunos candidatos. Aparentemente não há uma diretriz comum para esse processo. Em relação aos alunos bolsistas do Programa de Desenvolvimento Institucional (PDI) que fazem estágio no setor educativo, Anita afirma que

Divulgamos as vagas amplamente e pedimos que eles informem porquê desejam participar do projeto. A gente faz um esforço para analisar essas respostas. Estamos recebendo um número enorme de inscrições, o interesse é muito grande, e [o processo seletivo] toma bastante tempo.Anita

No desenvolvimento das entrevistas, quando questionei se o coeficiente de rendimento (CR) se configura como um critério para a seleção dos bolsistas PDI, Anita afirmou que, por conta do edital, foi preciso selecionar alunos com um $\mathrm{CR}$ superior a 6 , mas que isso não era um critério importante para decidir, dentre os candidatos que cumpriam esse requisito, quais seriam selecionados.

Levamos em consideração porque o edital previa que só poderiam se vincular aos projetos apoiados por esse edital alunos com CR superior a 6 , então tivemos que divulgar que o CR deveria ser superior a 6, por uma questão do edital da bolsa, mas não costumamos avaliar CR mesmo, só exigimos que eles tivessem $\mathrm{CR}$ acima de 6 , mas não fizemos uma diferenciação entre 6,5 e o 9. - Anita

Outro critério utilizado para a seleção de bolsistas no Museu Nacional foi o fato do aluno ter participado de um curso de extensão oferecido pela instituição para a formação de mediadores. No curso são oferecidas vagas a estudantes de graduação, professores da rede pública e privada e profissionais da área de turismo. Caso um aluno da universidade tenha feito o curso e se interesse em se candidatar à bolsa PDI, já se configuraria uma vantagem no processo seletivo.

Tivemos alguns candidatos que tinham participado do curso mesmo antes de serem informados de que disponibilizaríamos bolsas. Então esses já tiveram mais pontos no processo seletivo, porque é claro que é muito interessante para o setor educativo, é um esforço muito grande da nossa 
parte até em conseguir envolver docentes de todos os departamentos do museu, técnicos de vários departamentos do museu, e convidar pessoas de fora para que estejam aqui naquelas duas semanas oferecendo esse curso, e é claro que um estudante de graduação que dedicou duas semanas, que teve interesse em participar do processo seletivo para entrar no curso, participar do curso, que concluiu o curso, cumprindo a carga horária exigida, revela um interesse em trabalhar, em atuar, no setor educativo do Museu. Anita

Anita também afirma que as vagas são abertas para alunos de graduações específicas, embora, em alguns casos, não exista procura de alunos desses cursos para o estágio no Museu. A entrevistada destaca a falta de interesse dos alunos dos cursos de Pedagogia e de Letras-Libras.

História, Ciências Sociais, Ciências Biológicas, História da Arte..., Geografia, Comunicação Social... esses que se inscreveram, foram selecionados, mas abrimos vagas para estudante, por exemplo, de Pedagogia também, só que temos pouca adesão por parte do estudante de Pedagogia, são poucos os que se inscrevem. Infelizmente temos observado que o grau de interesse dos estudantes de Pedagogia, comparado com outros cursos, é claro que eu não posso generalizar, estou falando por uma experiência própria, abrindo vagas e disponibilizando vagas de fato para estudantes de Pedagogia tem um índice de inscrições, de candidaturas, pequeno e o grau de interesse ou mesmo de aproximação, ou de proximidade, com os museus, com campo dos museus também é inferior comparado com outros cursos. Tínhamos também interesse em receber estudantes de Letras Libras [da universidade], mas encontramos dificuldade, recebemos poucas inscrições de estudantes de Libras, ou às vezes não recebemos inscrições para participar do processo seletivo. Mas existe interesse da nossa parte em receber esses estudantes tanto de Pedagogia quanto de Letras Libras. Anita

Em relação aos alunos de ensino médio, o processo seletivo acontece

de forma independente no Colégio Pedro II. As pesquisadoras entrevistadas afirmam não ter conhecimento dos critérios utilizados pelo colégio para esse processo.

O Museu não costuma ter nenhuma participação no processo seletivo, recebemos do colégio indicação de quais seriam os alunos selecionados para os departamentos ou setores, laboratórios que disponibilizaram vagas para esses estagiários. Então quem faz a seleção dos estagiários do Colégio Pedro II é o próprio colégio. A princípio [os alunos] são voluntários, depois alguns deles se tornam bolsistas a partir de uma distribuição de bolsas que fazemos internamente de bolsas da FAPERJ que são concedidas ao museu e que distribuímos. - Anita

[...] colocamos no projeto, numa planilha, que isso vai para o Pedro II. Lá eles vão ver no pool de vagas que o museu ofereceu em todas as áreas que eu falei e aí eles vão apresentar isso para os alunos, olha o Museu Nacional tem tantas vagas na botânica, na palinologia... palinologia vem a ser o que, aí mostra para eles o projeto que mandamos. Como é feito, se é com audiovisual, se é falado, nós não sabemos. - Graziela 
As vagas de estágio que são abertas para os alunos de ensino médio dependem do interesse de pesquisadores e técnicos do Museu Nacional em desenvolver esse tipo de orientação.

[...] fazemos [setor educativo] uma consulta interna junto aos setores do Museu, na medida que estamos na coordenação do PIC-Jr., acerca do número de vagas que os orientadores, podem ser docentes ou técnicos do museu, pretendem disponibilizar para o ano seguinte... disponibilizamos um número " $x$ " de vagas de forma que a coordenação do programa no Colégio Pedro II divulga essas vagas. - Anita

No Museu da Vida, o curso de graduação de origem também é um critério para a seleção dos alunos para as bolsas de Iniciação à Divulgação Científica e Popularização da Ciência (PROPOP). Mas também é levado em consideração o período que o aluno está cursando.

Os critérios nossos hoje são, além da adequação na entrevista, existe uma entrevista, tem uma seleção por currículo, então quais são os critérios para você selecionar o currículo; estar dentro do curso de graduação desejado, entre o terceiro e o sexto período, entendendo que antes do terceiro período ele não teve tempo para maturar, nem para ter contato com seu próprio curso de graduação e que, após o sexto período, na maioria dos cursos, o graduando está na reta final. - Eric

Na fala do Eric, é possível perceber que a delimitação do tipo de curso de origem do aluno já na seleção é importante para que haja um diálogo entre os conhecimentos que o aluno aprende na universidade e os conteúdos expositivos das diferentes seções do museu. Além disso, percebe-se uma preocupação de que o aluno tenha uma experiência formativa efetiva.

[...] o curso de graduação é um critério, porque não temos como pegar um bolsista que não consiga dialogar com o que ele está fazendo na universidade de alguma maneira com o espaço que nós teremos para ele aqui. [...] Já tivemos uma experiência com um bolsista de farmácia que não aproveitou a contento a bolsa na nossa avaliação. Ele ficou aqui os dois anos, foi uma menina, ela ficou aqui os dois anos, mas a nossa avaliação depois, a posteriori, foi não temos clareza de que ela aproveitou todo um potencial que poderia aproveitar. Ainda mais quando você pega e compara com outro. Então tentamos agora buscar esse diálogo. Evitar discrepâncias. - Eric

Perguntei então se o Museu da Vida já abria as vagas para bolsas direcionadas para cursos específicos e Eric respondeu que sim, que as bolsas já eram direcionadas para alunos de determinados cursos de graduação. "Abrimos bolsa para estudantes de química e física ou biologia, matemática ou artes cênicas e história e assim vai..." 
Segundo Eric, o coeficiente de rendimento não é um critério utilizado na seleção, sendo aplicado apenas na época em que o museu recebia bolsistas de IC, por exigência do edital da agência de fomento.

Em relação aos bolsistas de ensino médio, que fazem a iniciação à produção cultural (Pró-Cultural), o pré-requisito é que o aluno esteja cursando a segunda ou terceira série do ensino médio em uma escola pública do entorno do Museu. Marina vai às escolas com as quais já tem parceria e divulga o curso e considera que a seleção é necessária porque há mais alunos inscritos do que vagas.

Vou até as escolas, levo panfletinho e cartazes, e aí vou em cada sala, apresento programa e convido para as inscrições avisando que estão abertas. E aí fazemos as inscrições aqui e tem um processo seletivo que tem três etapas: tem uma redação que é eliminatória - infelizmente temos que fazer seleção porque normalmente tem 100 inscritos, 120 inscritos e só temos 25 vagas então a seleção não tem muito jeito -é uma redação, depois uma dinâmica de grupo e depois numa entrevista. Formamos então a turma do ano. - Marina

No Museu da Química, que atualmente conta com bolsistas de extensão, os critérios parecem ser definidos pelos editais de bolsas e não pela equipe do museu. $O$ aluno precisa estar matriculado em um curso de graduação da UFRJ. A única restrição imposta pelo museu é que o aluno não esteja no último ano do curso, pois neste caso ele poderia deixar a bolsa no meio do processo formativo. O CR mais uma vez não é um critério de seleção.

[...] tem que ser um aluno da UFRJ, de qualquer curso porque não é só Química, temos aspectos históricos e de organização de acervo que pode então admitir outros cursos aqui, de matrícula ativa e que não seja formando, então, digamos, no primeiro ano, como calouro que entra já pode logo no primeiro período assumir, coisa que na pesquisa não é possível, que é a partir do terceiro, a extensão admite desde o primeiro até o último, penúltimo período dele. Então geralmente consideramos o último ano, porque ele pega a bolsa e daqui a pouco sai do curso, se forma, então seria contraproducente, ele não vai aproveitar nada e você ainda vai desperdiçar um esforço em cima de um trabalho que vai logo ser interrompido. Não há exigência de nota, $\mathrm{CR}$, somente matrícula ativa. - Antônio

O MAST só possui bolsistas PIBIC, e, portanto, segue o modelo proposto na Resolução Normativa ํㅜㄱ/06 do CNPq para a concessão de bolsas dessa natureza. As vagas disponíveis são divulgadas em edital publicado pelo próprio Museu. Entretanto, cabe a cada orientador definir os critérios de seleção de seus bolsistas. 
Hoje fazemos uma espécie de edital, nós temos um edital e entra na página do MAST e recebemos currículos. Então, distribuímos os currículos mais ou menos de acordo com as demandas do pesquisador e o pesquisador faz depois avaliação, uma entrevista com os candidatos, por exemplo 10 currículos, ele pode selecionar cinco, chamar cinco pessoas e a partir da conversa e da disponibilidade, então, ele faz a seleção final. A decisão final é sempre do pesquisador. - Mauro

César, que é coordenador do setor educativo, afirma que mesmo havendo a divulgação das vagas por edital, a divulgação mais significativa é a que ocorre diretamente entre os bolsistas atuais e seus colegas de faculdade.

Tem um edital que é lançado, mas normalmente é indicação dos próprios bolsistas porque como eles fazem graduação eles têm os colegas. Então um conversa com o outro ah, vai lá, vai abrir uma bolsa. E aí, normalmente, marcamos uma entrevista, se o estudante se interessar e também acharmos que a coisa vai render, eles ficam. - César

Sobre o uso do coeficiente de rendimento como critério de seleção, Mauro declara que este aspecto não é uma exigência do CNPq, mas que pode ser um critério usado pelo orientador durante a seleção. Contudo, considera que esse seria um critério que poderia ser usado como desempate de dois candidatos, pois o CR não necessariamente reflete se um candidato tem "aptidão para a pesquisa".

[...] isso [uso do CR como critério de seleção] não está especificado no nosso edital, mas é claro que o pesquisador que está avaliando pode levar em conta, entre dois candidatos, um tem CR maior, outro tem CR menor, isso indica alguma coisa, mas não necessariamente indica muita coisa não, ou seja, o quantitativo nem sempre indica o qualitativo. Por isso a entrevista é fundamental, porque você selecionar apenas pelo currículo, ou pelo histórico escolar, pode levar a um engano, quer dizer, uma pessoa que é muito aplicada na hora de fazer suas provas, mas cuja a disposição para pesquisa, que tem que ser meio obsessivo, meio chato. Você sabe como é essas coisas (risos). Perseguir um objeto o tempo todo ali, às vezes a pessoa não tem essa disponibilidade, então a entrevista se torna necessária pelo aspecto qualitativo da questão. - Mauro

Em relação ao curso de origem ser um critério de seleção, pela fala

de Mauro, é possível constatar que não é à priori, mas que os pesquisadores do MAST selecionam sim os alunos de acordo com seu curso de origem, de acordo com suas áreas de pesquisa.

Vai depender muito da especificidade do projeto. Pode ser, por exemplo, nós temos aqui, geralmente... como nós somos uma área de história da ciência, na nossa coordenação, de um modo geral, são meninos e meninas das ciências humanas. Praticamente História ou associados, mas nas outras áreas tem da Museologia, tem da Pedagogia, Biblioteconomia etc. Então vai depender muito, a área do aluno, do bolsista, da necessidade específica do projeto. Pode ser alguém de Informática, pode ser alguém de Física... Então 
nós não temos aqui, digamos, uma especificidade de área, vai depender sempre da demanda do pesquisador. - Mauro

No Espaço COPPE, todos os alunos são bolsistas de extensão e a divulgação é feita a partir do que Ruth chama de "boca a boca". Os bolsistas atuais divulgam a disponibilidade de bolsas, os interessados procuram o museu e fazem uma entrevista. Como esse museu também pertence à universidade, os alunos têm que estar vinculados a seus cursos de graduação.

[...] temos um número pequeno de bolsistas, então acabamos chamando no boca a boca, nas salas perto, os amigos dos bolsistas que já estão, então fica mais fácil e mais rápido, porque, normalmente, quando acontece isso também [quando as bolsas são liberadas], você tem pressa para colocar o nome, então... se for fazer uma chamada vai demorar e acaba perdendo tempo. - Ruth

Outro critério utilizado para a seleção é a disponibilidade de tempo para as atividades relativas à bolsa. Segundo Ruth, esse é um critério, pois o Espaço tem horários de visitação restritos e esses bolsistas participam das atividades de visitação.

O uso do CR como critério de seleção também não parece ser um aspecto que define a seleção de um aluno no Espaço COPPE, mas, por outro lado, não é totalmente ignorado.

Conversamos, vemos o $\mathrm{CR}$, mas eu acho que, assim, mais ou menos, não vamos pegar um CR muito baixo, mas, eu não vejo a necessidade de ter um CR muito alto também, eu acho que tem que ter uma média que seja o suficiente. - Ruth

Sobre o curso de origem como critério de seleção dos bolsistas, Ruth afirma que antes de trabalhar no museu havia uma prioridade em selecionar alunos que fossem de cursos relacionados aos temas das oficinas e exposições realizadas, mas depois de sua chegada e de sua atuação essa exigência foi mudando.

A partir do momento em que eu cheguei aqui, eu tenho uma forma de pensar diferente, eu acho que quanto mais diversificada... são linguagens diferentes, são visões diferentes, então se você entende muito da engenharia talvez você não saiba passar para uma pessoa totalmente leiga aquele assunto, enquanto se o meu colega que ele é da biologia, vamos dizer, ele tendo o treinamento e a prática com os colegas que são da área, ele pode ter uma facilidade muito maior de passar o tema e o assunto que está sendo falado para uma pessoa que não entende do que a pessoa que entende. - Ruth

O Espaço Ciência Viva divulga anualmente a seleção de bolsistas através de um edital que não especifica o número de vagas, pois as bolsas 
serão disponibilizadas ao longo do processo. Dessa forma, o aluno pode iniciar o estágio como voluntário e passar a receber a bolsa ao longo do processo formativo. O edital de seleção é divulgado por meio digital, como em redes sociais; através de cartazes afixados na universidade, mas, como afirmou Ludmila, a divulgação também ocorre principalmente no "boca a boca". Como são muitos inscritos, a primeira etapa de seleção é o candidato escrever um texto explicando "qual o interesse em participar de um projeto de divulgação científica". Um grupo menor é então selecionado e convidado a ir à universidade para uma segunda etapa de seleção, momento em que devem produzir uma redação de cerca de 20 linhas explicando "porque estavam interessados em ter uma bolsa de extensão" no museu. Também são realizadas dinâmicas e entrevistas coletivas. Os candidatos selecionados nessa etapa participam de um curso que é oferecido no museu, aberto também a professores da rede pública e privada. A partir do curso são selecionados os alunos que irão atuar como estagiários, mas todos que completam o curso compõem um cadastro de reserva.

Ao longo do ano, podem surgir novos projetos e novas demandas de estagiários. Neste caso, são aproveitados os nomes do cadastro de reserva ou são feitas novas seleções porque os candidatos pré-selecionados podem não ter o perfil adequado para o novo projeto.

Tentamos pegar pessoas que fizeram o curso, pois já estão por mais preparadas, mas às vezes você não tem o perfil adequado ou as pessoas não querem.- Ludmila

Em relação ao curso de origem ser um critério de seleção, Ludmila afirma que não há uma restrição. Assim como Fernando, valoriza a formação de uma equipe de estagiários diversificada, mas explica que de certa forma há uma escolha baseada na área de graduação dos alunos, de acordo com os temas trabalhados nos projetos do museu.

De um modo geral, esse curso que damos é aberto. Agora, na hora da seleção é claro que você acaba selecionando um pouco, dentro da quantidade de bolsas que você tem, você acaba privilegiando um pouco mais algumas áreas, mas também é importante ter a diversidade. Então tentamos pegar um pouco mais esse processo. Como é uma bolsa de iniciação científica do tipo 20 horas é um processo que por mais que, às vezes, você, que não adianta pegar uma pessoa que é de uma área completamente diferente para de repente já ter que estar aqui na semana que vem mediando as crianças em um experimento de ciências. Então isso 
também traz uma certa dificuldade e por isso que eu não posso pegar também muita gente de outras áreas sem garantir que haja pessoas que possam dar apoio, tirar dúvidas e colaborar no dia a dia da ação deles. Ludmila

A partir dos relatos dos entrevistados, é possível perceber que o tipo de bolsa oferecida pode ser um determinante para a escolha dos critérios de seleção dos alunos, na medida em que alguns editais delimitam critérios específicos. Esse é o caso dos museus que pertencem à universidade e possuem bolsistas de extensão ou de desenvolvimento institucional. Nestes casos, o aluno tem que ser necessariamente aluno de graduação da UFRJ.

Embora a maioria dos museus afirme lançar um edital de seleção ou, pelo menos, fazer uma chamada pública sobre a disponibilidade de bolsas, a divulgação feita pelos atuais bolsistas com seus colegas de graduação parece ser o meio mais efetivo para atrair novos candidatos à bolsa.

Em relação aos critérios de seleção, os trabalhos levantados por Massi e Queiroz (2010) sobre a IC indicam que, em geral, os orientadores valorizam que os alunos tenham vocação para a pesquisa (capacidade de tomar decisões, trabalhar com autonomia, ter aptidão para os conteúdos teóricos da área da pesquisa), que estejam em algum determinado período do curso (mais para o início ou para o final). O único entrevistado que ressaltou a questão de uma aptidão para a pesquisa como aspecto importante foi Mauro, mas o período em que o aluno se encontra parece ser importante para todos os museus, em especial, que o aluno não esteja muito próximo do final do curso, pois há um temor de que ele abandone a bolsa no meio do processo devido a sua graduação.

As pesquisas realizadas sobre IC mostram que alguns orientadores apreciam que o aluno tenha cursado a disciplina ministrada por esse orientador e que alguns professores inclusive ministram seus cursos já na expectativa de encontrar candidatos (MASSI e QUEIROZ, 2010). Esse aspecto é observado no Museu Nacional e no Espaço Ciência Viva, que valorizam que os alunos tenham participado de seus cursos de formação de mediadores. É interessante destacar que esses dois museus afirmaram ter muita procura por vagas de estágio. 
A capacidade de organização frente às diferentes tarefas do estágio e do curso (provas, saídas, seminários) também parece ser um critério importante. Entretanto, esse aspecto não foi elencado pelos entrevistados. $\mathrm{O}$ que foi destacado nas entrevistas com os profissionais dos Museu Nacional, Museu da Química, MAST e ECV é que o aluno precisa disponibilizar um horário fixo em um determinado dia da semana. Em geral esse é o dia em que ocorrem os encontros formativos, que, na maioria dos casos, é na segunda-feira, dia que os museus, em sua maioria, não são abertos ao público.

Outro aspecto a ser destacado é a pouca preocupação com o desempenho acadêmico como critério de seleção. Brid e Pereira (2004), ao avaliarem os objetivos do PIBIC, afirmam que a IC tem como critério selecionar os melhores alunos da universidade, incentivando assim os talentos em potencial. Para esses autores, essa seletividade faz com que poucos alunos participem dessa experiência formativa, privilegiando aqueles que sejam considerados mais 'capacitados' e 'promissores' 56 . Massi e Queiroz (2010), entretanto, apontam que há pesquisas que indicam que o coeficiente de rendimento costuma ser um critério mencionado pelos orientadores como critério seletivo, mas não é um fator determinante, aproximando-se da perspectiva indicada pelos entrevistados. Na verdade, a maior parte afirma não valorizar o CR na escolha de um candidato à bolsa, sendo utilizado somente em caso de exigência do edital. Apenas Mauro declarou que o CR, embora não seja o critério mais importante, pode se configurar como um critério de desempate e, na opinião de Ruth, o candidato não deve ter um $\mathrm{CR}$ muito baixo.

Uma questão não abordada no levantamento realizado por Massi e Queiroz (2010), e que talvez seja próprio do estágio nos ambientes de museu, é o tipo de graduação (curso de origem) que o aluno está cursando enquanto critério a ser levado em consideração no processo de seleção. $\mathrm{Na}$ universidade talvez seja natural que um aluno de Biologia, por exemplo, faça estágio com pesquisadores da área de Ciências Biomédicas. Entretanto, a fala dos entrevistados mostra que os museus valorizam

\footnotetext{
${ }^{56}$ Aspas dos autores.
} 
equipes multidisciplinares. Em alguns casos, a temática principal do museu (biologia, física, astronomia, química) faz com que haja mais bolsistas desses cursos, mas na fala de quase todos os entrevistados é possível perceber uma tentativa de atrair alunos de outras áreas como história, jornalismo, pedagogia e libras. Cabe o seguinte questionamento: até que ponto a instituição quer receber esses alunos para formar diferentes profissionais na área de educação museal, ou carece de profissionais dessas áreas em suas próprias equipes de trabalho? Esta reflexão será aprofundada no próximo capítulo.

Em relação aos bolsistas de ensino médio, parece haver uma menor preocupação em relação aos critérios de seleção. No caso do Museu Nacional, cabe ao colégio selecionar os alunos e o museu só disponibiliza o número de vagas e áreas de estágio. No Museu da Vida, parece existir uma demanda maior do que vagas, sendo, portanto, necessário fazer a seleção.

\subsection{2.}

\section{As atividades desenvolvidas pelos bolsistas}

Um outro questionamento abordado ao longo das entrevistas foi se já havia atividades pré-determinadas para os alunos quando o estágio era iniciado. A preocupação era entender se existia um plano de trabalho para esses alunos.

Uma crítica que os alunos de IC têm ao processo formativo é que o contato com seus orientadores durante esse período é reduzido, e se decepcionam com o andamento do trabalho (BRID e PEREIRA, 2004). Apesar de não ter entrevistado alunos, como minha preocupação era a priori entender a IC como um processo formativo específico, julguei importante investigar se havia uma preocupação de que fossem desenvolvidas atividades específicas para esses alunos.

No Museu Nacional, cabe a cada orientador determinar as atividades que serão desenvolvidas pelos alunos de IC de graduação ou ensino médio, bolsistas ou voluntários, nos diferentes setores. Entretanto, os bolsistas do setor educativo parecem ter tarefas atribuídas desde o início do estágio (lembrando que, em relação aos alunos de graduação, não há 
bolsistas de IC nesse setor, e sim PDI). De acordo com Anita, além do bolsista se envolver com as atividades educativas do museu, há uma tentativa de que ele se engaje em todo o processo de elaboração e realização das atividades e que reflita sobre questões relacionadas à pedagogia museal. A entrevistada considera que o bolsista:

[...] tem tarefas. A maior parte do tempo é dedicada à implementação de atividades educativas voltadas aos diferentes públicos do museu, mas vamos buscando que eles desenvolvam atividades de estudo mesmo do campo da educação museal e também quem já tem, na concepção, no planejamento de projetos educativos, na implementação e na avaliação que eles participem de fato de todo esse processo. - Anita

Em relação aos alunos de ensino médio, Anita explica que aqueles que fazem estágio voluntário atuam basicamente na "implementação de atividades educativas, especialmente visitas mediadas realizadas junto ao público de visitação programada". Mas a partir do momento em que tornamse bolsistas Jovens Talentos da FAPERJ, considerando que a bolsa é uma bolsa de IC-EM, os alunos passam a se vincular a um dos projetos de pesquisa do setor educativo.

No Museu da Vida não há um plano de trabalho muito fechado, a menos que o bolsista entre para atuar em uma atividade que esteja em andamento, como uma peça de teatro, por exemplo. Pela fala de Eric, a preocupação maior quando o bolsista inicia seu estágio é, de acordo com o seu perfil, em qual atividade ele irá se inserir. Segundo o entrevistado:

Nós temos áreas de atuação delimitadas. Isso está em discussão: se é o melhor modelo ou não (risos). Talvez o melhor modelo seja esse que você falou: dele entrar e ter uma tarefa pré-determinada e aí você fecha ainda mais o perfil do aluno na hora da entrevista. Hoje o perfil está um pouco mais aberto exatamente em função dele não ter uma tarefa. [...] em alguns casos até acontece isso, vamos dizer assim, temos uma ação em andamento, uma peça de teatro, ou uma esquete teatral, então se o bolsistas é de artes cênicas é óbvio que ele vai para aquela ação. Designado para ajudar no desenvolvimento da peça ou do esquete e depois atuar nela. Mas via de regra, o que delimitamos previamente é, na realidade, a área de atuação do bolsista. - Eric

Já em relação aos bolsistas de ensino médio, de Iniciação à Produção Cultural (Pró-Cultural), parece existir um modelo de formação estruturado. De acordo com Marina, ao iniciarem o curso, a primeira atividade dos alunos é conhecer o museu, seus espaços, profissionais e história. Em seguida realizam várias dinâmicas que discutem questões relacionadas à identidade (do aluno e do grupo). Por fim há o módulo de produção cultural, 
onde os alunos têm oficinas com convidados, visitas técnicas e produzem eventos. Marina explica que eles começam planejando pequenos eventos e terminam com a elaboração de uma exposição no próprio museu.

Eles produzem vários eventos durante o ano. Primeiro começa com um de pequeno porte, que são duas festas de aniversário dos aniversariantes do primeiro semestre e do segundo. Que não é uma arrumação de festa comum, eles fazem dentro de um esquema de um projeto, eles fazem um projeto de produção cultural, apresentam no PowerPoint, com recursos, com material necessário, com cronograma, com tudo que um projeto de produção cultural necessita. Então eles fazem e depois fazem a produção de pequenos eventos aqui. Esse ano vão fazer de uma exposição de fotografia científica porque eles vão ter umas aulas e uma oficina de fotografia científica aqui no Espaço de Ciência. Nunca descolamos o Espaço de Ciência e Saúde, sempre colocamos essas questões juntas. E aí eles irão fazer um de minicurso de fotografia científica porque a arte é uma forma de expressão também, é uma forma de linguagem. E aí, eles vão expor depois aqui as fotografias, vão ser expostas aqui no museu. Eles fazem exposições aqui para o público. - Marina

Antônio, entrevistado do Museu da Química, explicou que há um plano de trabalho inicial, porque isso é uma exigência das bolsas de extensão. Assim, cada aluno possui um plano de trabalho individualizado, o que não impede que seu trabalho possa interagir com o dos demais bolsistas.

No MAST há uma tentativa de que os bolsistas tenham tarefas coletivas na instituição, como a participação em seminários, mas, de acordo com Mauro, as tarefas desenvolvidas pelos bolsistas "são específicas do plano de trabalho que ele desenvolveu junto com seu pesquisador". Mais uma vez fica então nas mãos do orientador desenvolver um plano de trabalho para o aluno.

Já César explica que os bolsistas do setor educativo podem escolher a priori se engajar em uma atividade de sua preferência, e de acordo com o seu perfil. Há atividades educativas para crianças, cursos de capacitação para professores, atividades móveis em diferentes cidades, entre outras. Mas afirma que além desse engajamento há "o trabalho mesmo ligado à bolsa". Quando pergunto como é esse "trabalho ligado à bolsa", César esclarece que depende do tipo de projeto desenvolvido.

No Espaço COPPE, todos os bolsistas (todos de extensão) se envolvem em atividades de mediação na exposição, além de eventos externos, como oficinas na Semana Nacional de Ciência e Tecnologia e na 
Reunião da Sociedade Brasileira para o Progresso da Ciência (SBPC). De acordo com Ruth, os bolsistas participam da escolha dos temas e da elaboração das oficinas.

No ECV, o aluno já entra com um plano de trabalho que foi submetido à agência de fomento da bolsa e seleciona os dias da semana em que estará presente, de acordo com o grupo temático no qual irá se inserir, porque há dias fixos de formação para cada grupo temático. Todos os bolsistas participam também da elaboração de uma atividade temática que acontece uma vez por mês em um sábado. Fernando explica que o horário do aluno é dividido em três núcleos de trabalho:

Então basicamente eu diria que temos essa estrutura de formação em que ele tem uma parte da carga horária em que vai estar envolvido com discussões, com os problemas voltados para o atendimento e a mediação das escolas e visitantes, o outro são os grupos que trabalho aqui, ele vai estar envolvido, e a organização dos sábados. Então isso é que gera basicamente esses três núcleos do trabalho. - Fernando

Em relação às atividades desenvolvidas pelos bolsistas nos diferentes museus, é possível afirmar que, em geral, as atividades para os bolsistas de IC ficam a cargo das escolhas de cada orientador, porém, para os bolsistas de extensão há uma necessidade de encaminhamento de plano de trabalho para a solicitação das bolsas, ou seja, este plano já é estabelecido a priori.

No caso dos bolsistas PDI do Museu Nacional, as atividades ligadas às atividades educativas são estabelecidas no início do estágio e há uma tentativa de que os alunos se engajem também em atividades de estudo e pesquisa que dialoguem com a prática.

Já os alunos do PROPOP do Museu da Vida só terão atividades prédefinidas se isso for uma demanda de alguma atividade desenvolvida pelo Museu.

Portanto, a definição das atividades a serem desenvolvidas pelos bolsistas pode ser consequência da natureza da bolsa. No caso das bolsas de IC, os editais em geral deixam a cargo das instituições e orientadores definir os planos de trabalho. Já os editais de extensão solicitam um planejamento prévio das atividades.

A partir das entrevistas, foi possível verificar que, nos museus estudados, no caso das bolsas de IC ou IC-EM, fica a cargo de cada 
orientador definir com o seu bolsista as atividades a serem desenvolvidas. Por ser uma bolsa de IC, há necessidade de que o aluno esteja envolvido em atividades de pesquisa, como fica evidente na fala de Anita, ao afirmar que quando os alunos de ensino médio passam a receber a bolsa de ICEM da FAPERJ é preciso que se vinculem a uma linha de pesquisa do setor educativo. Já no caso dos bolsistas de extensão, os planos de trabalho são definidos a priori quando o projeto é submetido para a aprovação. Assim o aluno já inicia o estágio com atividades pré-determinadas.

Para os demais tipos de bolsa, parece caber a cada museu, ou aos formadores, definir como e quais serão as atividades desenvolvidas pelos alunos, a partir das demandas das instituições ou das visões sobre formação que os profissionais entrevistados possuem.

\subsection{3.}

\section{Apresentação dos resultados pelos bolsitas}

Apresentar o conhecimento gerado para seus pares é parte do processo de produção do conhecimento científico. Assim, essa é uma etapa formativa que deveria fazer parte da formação de um pesquisador.

Como discutido anteriormente, a própria resolução normativa nำ17/06 do CNPq sugere que os alunos de IC apresentem seus trabalhos em jornadas promovidas pela própria instituição, onde estarão presentes avaliadores internos e externos. Portanto, esse item foi abordado nas entrevistas, ou seja, se os alunos bolsistas participavam de jornadas ou apresentavam, de alguma forma, os resultados obtidos durante o estágio.

No Museu Nacional, os alunos de IC apresentam seus trabalhos na Semana Integrada da Universidade (SIAC). A UFRJ já teve uma jornada de apresentação de trabalhos só para os alunos de IC, e em separado um congresso que reunia as atividades de extensão. Hoje essas atividades são reunidas na SIAC, incluindo a apresentação de trabalhos realizados pelos alunos dentro dos três eixos do tripé universitário: ensino, pesquisa e extensão ${ }^{57}$.

57 A Semana de Integração Acadêmica (SIAC) da UFRJ reúne trabalhos de ensino, pesquisa e extensão de: (I) estudantes de graduação da UFRJ; (II) estudantes de graduação externos à UFRJ participantes de Programa/Projeto/Ação Institucional de 
Na fala de Anita, é possível perceber que a falta de obrigatoriedade de o aluno participar de jornadas acadêmicas, devido ao tipo da bolsa, faz com que os bolsistas do setor educativo (que não são bolsistas de IC) acabem não apresentando trabalhos nesse evento. A entrevistada também explica que o período entre o início da bolsa e a SIAC é muito curto, dificultando que haja algum tipo de resultado produzido para ser apresentado.

[...] os bolsistas de graduação, eles costumam [apresentar trabalho na SIAC], mas não existe essa regra, quer dizer, quando tínhamos bolsista de extensão existia uma obrigatoriedade, eles tinham que participar do Congresso de Extensão. Temos tido dificuldade para participar da SIAC porque as inscrições, o envio de trabalhos, acontecem em meados de maio e, por exemplo, as bolsas dos nossos atuais bolsistas foram concedidas no início de maio então... - Anita

Em relação aos alunos bolsistas de IC do ensino médio, o próprio edital da bolsa exige que eles elaborem um relatório final e que participem da jornada de iniciação científica para os bolsistas Jovens Talentos promovida pela própria FAPERJ. Além disso, alguns desses alunos participam também da SIAC.

[...] no ano passado nosso aluno de IC-Jr participou [da SIAC], e apresentou o trabalho na forma oral. E a apresentação dele foi excelente. Todos até elogiaram muito, por um menino de 16,17 anos, ter tranquilidade para apresentar, com segurança, o resultado do estudo dele. Então foi muito bonito. - Graziela

No Museu da Vida, o fato dos alunos do PROPOP não serem bolsistas de IC dificultava que participassem da jornada Fiocruz. Uma vez que o programa foi reformulado e passou a ser de Iniciação à Divulgação Científica e Popularização da Ciência, a participação desses alunos nas jornadas passa a ser uma possibilidade.

[...] o nosso programa, da maneira que ele estava caracterizado como apoio à divulgação científica, ele não se enquadrava como um programa que pudesse participar das jornadas de iniciação científica da Fiocruz, que é uma coisa que está bem caracterizada, com estudos bem caracterizados. Então

\footnotetext{
Pesquisa ou Extensão da UFRJ; (III) estudantes de Iniciação Científica do Ensino Médio inseridos em projetos vinculados à UFRJ; (IV) estudantes de pós-graduação vinculados a projetos de extensão e/ou de pesquisa na UFRJ. Todos os alunos participantes devem ser orientados por um professor ou técnico da universidade. O evento reúne a Jornada Giulio Massarani de Iniciação Científica, Tecnológica, Artística e Cultural; o Congresso de Extensão da UFRJ e demais eventos da universidade que envolvem a apresentação de trabalhos de alunos desde o ano de 2010. Mais informações em <http://www.siac.ufrj.br/>. Acesso em: 06 nov. 2017.
} 
passar esse programa para um programa de Iniciação à Divulgação e Popularização da Ciência é um processo, uma tentativa de darmos esse caráter. E temos a intenção de, até o ano que vem, talvez, de ter uma jornada para esse programa, uma jornada própria. $E$ tentar colocar isso na feira de iniciação científica da Fiocruz que é onde acontece a jornada de iniciação científica. E aí buscarmos, quem sabe, espaço dentro desse grande guarda-chuva que é esse programa de iniciação da Fiocruz, mas temos que adequar o programa para isso. - Eric

Eric também declara que, apesar do incentivo que os orientadores dão aos alunos para apresentarem trabalhos em outros eventos científicos, como encontros e congressos, há uma limitação em decorrência da falta de verbas para financiar essa participação.

[...] sempre, desde o início, tentamos estimulá-los a participar dos encontros das suas áreas. Então, por exemplo, os estudantes de biologia para o Erebio, o estudante de história para o ANPUH, os de Ciências sociais ia para a ANPOC, por exemplo. Sempre estimulamos e isso é um problema, porque assim, é um programa muito grande de bolsistas, você não tem condição de pagar pôster para todos esses bolsistas, inscrição para esses bolsistas, muito menos a passagem. Esse é um fator limitante considerável. Então o bolsista fica muito por si mesmo, por seus próprios meios, então, você estimula, mas você não dá ao mesmo tempo todas as condições para que a pessoa participe. - Eric

Ao final de cada semestre, há também incentivo para que cada aluno bolsista produza um relatório, mas como esse relatório não parece ser obrigatório, alguns acabam não entregando. Uma estratégia encontrada pelo programa para incentivar que os alunos produzam esses textos é condicionar o certificado de estágio a sua entrega. Para Eric, os alunos não compreendem a importância da elaboração desses relatórios como forma de avaliação do estágio, mas como uma mera etapa burocrática.

[...] temos um relatório semestral que o bolsista é obrigado a fazer. É uma luta para o bolsista fazer esse relatório, é uma luta. E tem um relatório final que é outra luta. Inclusive condicionamos a declaração da bolsa à entrega do relatório porque senão ele vai embora e não entrega o relatório dele. São poucos aqueles que encaram o relatório como registro importante do processo dele. Eles não entendem, você fala relatório... e eles pensam que é uma peça burocrática e não um instrumento fundamental para avaliação do programa e do registro das atividades que eles desenvolveram aqui. Eric

A fala do entrevistado se aproxima do resultado encontrado por Brid e Pereira (2004). Ao levantarem a opinião de alunos de graduação sobre a sua participação em atividades de IC, os autores identificaram, dentre as queixas apontadas pelos alunos, a dificuldade da elaboração de relatórios. Analisando tanto a fala de Eric, quanto os dados de Brid e Pereira (2004), 
talvez seja necessário considerar que a formação dos alunos bolsistas deva incluir uma instrumentalização para que ele seja capaz de elaborar relatórios e outros registros próprios da atividade científica.

Em relação aos alunos de ensino médio bolsistas no Museu da Vida, a produção se dá no decorrer das oficinas realizadas e na elaboração e organização dos eventos. Pelo fato de ser uma Iniciação à Produção Cultural, não há preocupação de que o conhecimento gerado pelos alunos durante o processo formativo seja apresentado em eventos científicos e sim que eles planejem e organizem eventos culturais.

Já no Museu da Química e no Espaço COPPE, como os bolsistas são de extensão, eles são obrigados a apresentar pelo menos um trabalho por ano na SIAC. Além disso, Antônio (Museu da Química) relata também que, quando o Museu teve alunos de IC, além da produção ter sido apresentada nas jornadas, resultou na publicação de artigos sobre o acervo e suas possibilidades para a pesquisa e 0 ensino.

No MAST, há uma jornada que segue os moldes indicados pela resolução do CNPq. Todos os bolsistas participam da jornada e os trabalhos são avaliados por uma comissão composta por avaliadores internos e externos. Ao final da jornada é publicado um caderno de resumos dos trabalhos apresentados. Os alunos também elaboram relatórios.

$\mathrm{Na}$ fala de Mauro também é possível perceber que há um desejo da instituição de que os alunos participem de outros eventos científicos fora da instituição, mas esse desejo novamente esbarra na falta de verbas.

Infelizmente, a nossa situação, como o órgão federal tem algum limite, por exemplo, tem uma legislação que você não pode pagar passagem e diária para bolsistas. Então antes a melhor apresentação era indicada para apresentar um trabalho na SBPC. Ótimo! Maravilha! Mas aí, como é que eu mando esse bolsista para a SBPC se eu legalmente não posso pagar nem diária, nem passagem? Então fica um prêmio meio vazio, então por um lado, eu tenho isso: eu tenho essas facilidades todas, os equipamentos, o clima, o fato de você estar lidando com vários pesquisadores etc. etc., mas por outro lado a gente tem essas limitações da legislação também, tudo isso amarra muito. - Mauro

Os bolsistas do Espaço Ciência Viva fazem um relatório diário ao final de cada atividade e também produzem um relatório final. Todos apresentam trabalho na SIAC da UFRJ. Atualmente, há também uma tentativa de que os protocolos produzidos para as atividades sejam 
publicados para que se tornem acessíveis para os próprios profissionais do museu e para professores e alunos visitantes.

[...] estamos tentando resgatar esses protocolos, dar uma outra reestruturada para que isso vire uma publicação. Ou pelo menos, vá para o site, porque aí fica como uma referência para professores, para orientadores que estiveram aqui, ou até para alunos que queiram reproduzir a experiência em sala de aula e fica, pelo menos, um registro simples da produção deles, que isso vai para o currículo dele como uma produção de material didático Ludmila

A partir dos relatos, é possível perceber que o tipo de bolsa interfere na produção dos alunos bolsistas, seja através da produção de relatórios ou da participação de jornadas acadêmicas. Quando essas atividades se configuram como uma exigência do edital, essa produção torna-se uma tarefa a ser cumprida. Quando não há essa exigência, mesmo que essa produção seja valorizada e considerada importante pelos coordenadores, ela pode não ocorrer. Mas, de uma forma geral, todos os entrevistados parecem reconhecer a importância da participação em jornadas e eventos científicos para a formação dos alunos bolsistas.

A produção escrita é destacada por Latour e Woolgar (1997) como a finalidade essencial da atividade de um cientista ${ }^{58}$. Assim, para que seja formado um pesquisador, o exercício da escrita presente na elaboração de resumos, artigos e apresentações configura-se como aspecto fundamental.

É importante destacar que quatro, dos seis museus estudados, estão vinculados direta ou indiretamente à UFRJ e possuem bolsistas desta universidade. Como a UFRJ reuniu as apresentações de trabalhos dos alunos bolsistas de IC e extensão na Semana de Integração Acadêmica (SIAC), todos os bolsistas têm a experiência de apresentar seu trabalho.

Para Massi e Queiroz (2015), a participação dos alunos de IC como autores em eventos científicos é relevante para sua formação. Os congressos e jornadas contribuem para a compreensão sobre a importância da socialização do conhecimento e para a socialização profissional a partir da convivência com outras pessoas, incluindo outros alunos bolsistas de graduação, alunos de pós-graduação, recém doutores e pesquisadores.

58 A discussão sobre os significados de formar um pesquisador será aprofundada no capítulo seguinte. 
Embora seja reconhecida a relevância da participação dos alunos em eventos científicos, foram recorrentes as falas sobre a limitação financeira, devido à falta de verbas para que os alunos participem de eventos fora de suas instituições.

\subsection{4.}

\section{Avaliando o processo formativo}

Se considerarmos que a IC é um processo formativo, uma de suas etapas deve ser a avaliação do processo. No caso do PIBIC, cabe aos comitês institucionais a avaliação do desempenho dos alunos, lembrando que para a avaliação da participação dos alunos nas Jornadas Institucionais devem ser convidados avaliadores externos (BRASIL, CNPq, 2006). Assim, perguntei aos profissionais entrevistados se os museus contavam com estratégias para avaliar essa formação e, em caso positivo, quais seriam as estratégias.

No Museu Nacional, os bolsistas ligados ao setor educativo têm um acompanhamento constante em relação à frequência e ao cumprimento de carga horária. Também são realizadas avaliações durante as reuniões de equipe, e os bolsistas têm feito também uma autoavaliação por escrito, que ajuda a equipe a identificar as dificuldades dos alunos ao longo do estágio, o que possibilita repensar as atividades de orientação.

Os bolsistas de IC-EM são avaliados através de relatórios entregues ao setor. O relatório também inclui a frequência e assiduidade dos alunos, que serve de base para a entrega dos certificados de conclusão do estágio.

A avaliação dos bolsistas PROPOP do Museu da Vida é feita basicamente a partir dos relatórios que eles mesmos produzem, mas, como Eric afirmou, os orientadores têm dificuldades em fazer com que todos os alunos entreguem esse relatório semestralmente.

Em relação aos alunos de ensino médio do Pró-Cultural, a avaliação parece ser mais constante. De acordo com Marina, a avaliação da equipe é feita a partir das avaliações e relatórios produzidos pelos alunos ao longo do processo. 
No Museu da Química, a avaliação é feita pelo orientador durante a elaboração dos relatórios relativos às bolsas. Essa avaliação é incluída após o aluno elaborar seu próprio relatório.

Segundo Mauro, no MAST, a avaliação se dá em duas dimensões: uma individual e uma institucional. A individual é feita em dois momentos, primeiro na relação direta entre o orientador e o aluno, depois na jornada, momento em que o aluno é avaliado pelos demais avaliadores internos e externos. Segundo o entrevistado, a jornada também possibilita a avaliação do programa PIBIC institucional de uma forma mais ampla, não se restringindo apenas à avaliação dos alunos.

Há dois momentos: a avaliação individual, que é da relação direta do orientador com seu bolsista, produziu, não produziu, participou, não participou, contribuiu, não contribuiu, foi negligente... que são, digamos, as avaliações em sentido menor do que o próprio cidadão sofre, quer dizer produzir, não produziu, se comprometeu, fez, a qualidade de ensino corresponde, não corresponde? Então essa é uma primeira avaliação, que é uma avaliação que dura o tempo todo. Há uma avaliação que é institucional que é feita durante a jornada, e aí é uma avaliação individual e coletiva, porque também se avalia, nessa jornada se avalia o programa, isso é, o conjunto dos bolsistas, conjunto do que foi produzido trouxe contribuições para a instituição? Corresponde à missão institucional? Está realmente fazendo valer ter o programa PIBIC? O que a instituição está precisando? Então, esse momento da jornada é muito mais que de uma apresentação apenas formal, ela também o é, mas é também o momento da avaliação do projeto, do bolsista e do programa. Então é um momento em que se faz uma reflexão maior sobre o próprio programa. Por outro lado, essas avaliações correspondem aos seguintes: esse bolsista foi bem avaliado? Então, digamos, além de ele receber um relatório, ou um parecer favorável, o que é muito bom para o bolsista para um futuro que ele pleiteie alguma coisa, ele tem um relatório, vai ser um relatório que diz esse bolsista, se ele foi excelente. Ou no plano oposto, quer dizer, pode servir, digamos, para cancelar a bolsa daquele bolsista. Aquele bolsista não produziu, recebeu, mas não fez jus ao que ele recebeu. Ou se comprometeu, ou não produziu aquilo que se comprometeu. Então essas duas avaliações: a avaliação do pesquisador e essa avaliação coletiva se juntam para o programa do próximo ano decidir quem continuará, quem não continuará, Mauro

No Espaço COPPE, os alunos são avaliados em reuniões de equipe e, por exigência do edital da bolsa, é produzido um relatório. Essa exigência fica explícita na fala de Ruth, que ressalta também que a avaliação é realizada, mas que não há uma preocupação em "dar uma nota" aos alunos.

[...] temos que apresentar um relatório, mas não precisa, nunca foi solicitado uma nota, uma avaliação [...] aí, as pessoas acabam não fazendo, já que não tem uma necessidade. - Ruth 
Os bolsistas do ECV têm dois tipos de avaliação. Como ocorre no MAST, uma parte da avaliação é feita diretamente pelo orientador e a outra está relacionada às atividades de mediação. O Espaço possui uma hierarquia em que os mediadores se dividem entre iniciantes e seniores. Ao final das atividades com o público é feita uma avaliação com o grupo que atuou com a mediação. Além disso, os mediadores seniores também se reúnem entre si para avaliar a atuação dos mediadores iniciantes, como explica Fernando.

[...] normalmente, o responsável é sempre um mediador sênior, ou mais de um quando é possível. Então a ideia é que ele ajude a organizar e os mediadores colaborem. Então ele passa a ser a referência, é ele que centraliza depois no final a discussão com o grupo da avaliação diária e os seniores eles se reúnem também para avaliar os mediadores. Então a ideia é que a gente se reúna, não conseguimos manter uma periodicidade assim tão quanto gostaríamos, mas tem esse grupo que também vai fazer uma avaliação quando conseguimos nos reunir para ver o acompanhamento dos bolsistas. - Fernando

Ohayon e Colaboradoras (2007) discutem que a partir da avaliação é possível fazer um controle da eficácia dos programas de Iniciação Cientifica. Vale esclarecer que como eficácia, consideram o fato do programa atingir seus objetivos pré-determinados. Para os autores, a avaliação também leva a uma melhoria do programa, à identificação de insuficiências e potencialidades ao longo do processo e à possibilidade de avanços na da formação do aluno. A avaliação permite, então, que a IC desempenhe a sua função de locus para a aprendizagem e produção do conhecimento.

O tipo da bolsa parece influenciar a abordagem utilizada para a avaliação do estágio nas instituições estudadas. Os bolsistas de IC do Museu Nacional e do MAST são avaliados por seus orientadores e por comitês avaliadores (internos e externos) através da participação em Jornadas, como indica a Resolução Normativa do PIBIC (BRASIL. CNPq, 2006). Os bolsistas de IC-EM do Museu Nacional são avaliados pelas mesmas metodologias (avaliação do orientador, participação em jornadas e elaboração de relatório) em decorrência da determinação do Programa Jovens Talentos da FAPERJ.

No caso dos bolsistas de extensão (Museu da Química e do Espaço COPPE), a exigência de elaboração relatórios finais faz com que essa seja 
uma prática avaliativa obrigatória. A importância da avaliação das atividades de extensão é objeto de debate do Fórum Nacional de PróReitores de Extensão das Universidades Públicas Brasileiras (FOPROEX). Diferentemente da IC, a avaliação das atividades de extensão está mais relacionada à consolidação das práticas extensionistas nas universidades, considerando que a extensão é o eixo mais recente do tripé universitário. ${ }^{59}$ Nesse sentido o foco da avaliação das atividades de extensão são a consolidação e aperfeiçoamento das práticas e a verificação se essas práticas cumprem seus objetivos (FOPROEX, 2000).

Para o FOPROEX (2000), avaliar as atividades de extensão e os processos formativos da universidade deve fazer parte da rotina acadêmica e deve ser um processo contínuo, que busque nortear as políticas institucionais, identificar distorções e corrigi-las e democratizar as informações.

Os dados da pesquisa aqui apresentados não permitem discutir se a avaliação realizada com os bolsistas nos museus estudados possibilita que se atinja os objetivos apontados por Ohayon e colaboradoras (2007) para a avaliação da IC e para a extensão universitária, apontados pelo FOPROEX (2000). Esse tipo de avaliação pode ser feita em outras instâncias, que não as investigadas, a partir da análise dos relatórios e de comissões.

Falas, como na de Anita (Museu Nacional) e Mauro (MAST), indicam que os processos avaliativos não se restringem a considerar apenas 0 desempenho do aluno, mas devem olhar também para a formação, permitindo que ela seja repensada. No Museu da Vida, embora Eric tenha indicado uma dificuldade na entrega dos relatórios por parte dos alunos, fica claro em sua explanação que o programa é constantemente repensado através de reuniões da equipe, o que é evidenciado pelas mudanças de objetivos e nomenclatura do programa ao longo do tempo. Em relação aos

\footnotetext{
${ }^{59}$ A expressão "tripé universitário" se refere às três funções da universidade: ensino, pesquisa e extensão, que passaram a ser dimensões indissociáveis na Constituição Federal de 1988 (artigo ํo 207). A dimensão formativa da extensão universitária será aprofundada no capítulo 6 .
} 
bolsistas do Pró-Cultural, a avaliação parece ser bem estruturada e constante.

\subsection{5.}

\section{E o aluno, avalia o processo?}

Além da avaliação realizada sobre os bolsistas, foi indagado ao longo das entrevistas se os próprios alunos avaliavam o processo formativo durante o período da bolsa e, em caso positivo, de que maneira essa avaliação era realizada.

No Museu Nacional, em relação aos alunos bolsistas de desenvolvimento institucional (PDI), ligados ao setor educativo, é feita uma autoavaliação por escrito, como já explicado na seção anterior. De acordo com Anita, na avaliação, o aluno tem a possibilidade de dizer se as expectativas em relação ao processo formativo estão sendo atendidas, e de que maneira a experiência pode ser melhorada. A avaliação é realizada, portanto, durante o processo e serve para a equipe repensar o trabalho formativo.

[...] pedimos que eles respondam questões relacionadas à prática e como eles se percebem nesse contexto para identificar se as expectativas deles quando se candidataram nesse processo seletivo estão sendo atendidas, se são compatíveis com as ideias que eles tinham sobre o trabalho que realizaram e agora, já vinculados ao projeto, qual seria o grau de motivação deles em relação ao trabalho implementado aqui. Quais são as dificuldades que eles percebem na formação e que deveríamos, então, investir para que eles se sintam mais seguros em relação ao trabalho que vem realizando. $E$ perguntamos claramente: o que o setor educativo poderia fazer para aprimorar a formação deles e melhorar a experiência deles aqui no museu e o que eles poderiam fazer para melhorar as atividades que eles vêm realizando aqui. - Anita

No que diz respeito aos alunos bolsistas do ensino médio, Graziela explica que não há nenhum tipo de avaliação realizada pelos alunos. Mas ela considera que, no caso dos alunos que optam por fazer o estágio avançado (quando o aluno continua no ano seguinte), há um sinal de que o aluno gostou do processo formativo e pretende dar continuidade ao estágio.

Não solicitamos isso da parte deles, mas quando eles querem continuar no avançado é uma demonstração de que eles querem continuar, agora se lá no Pedro II eles fazem essa avaliação isso nós não sabemos. Mas você nos deu uma boa ideia. - Graziela 
Em relação ao Museu da Vida, Eric explica que os bolsistas de graduação avaliam os momentos de formação, mas não há uma avaliação do processo como um todo e nem uma autoavaliação. Entretanto, declara que há um desejo por parte do grupo de orientadores de que a avaliação faça parte do processo, configurando-se como um dos tópicos discutidos nas reuniões da equipe sobre o programa de formação dos bolsistas.

Não conseguimos chegar a um consenso exatamente por causa da formação. E muito diferente a atuação. Também é difícil chegar a um denominador comum (risos) que crie um padrão para você poder avaliar. Está em construção. Nós fazemos isso, nós profissionais formados. Nós nos autoavaliamos também. Mas entendemos que é preciso ter uma autoavaliação na avaliação por parte do profissional que atua junto com um bolsista e uma avaliação do bolsista com relação à sua própria formação. Eric

No que tange aos bolsistas de ensino médio, do Pró-Cultural, é feita uma avaliação diária de todas as atividades por pelo menos quatro alunos. Já as visitas técnicas são avaliadas por todos eles.

No Museu da Química, em decorrência da exigência do edital de bolsas de extensão, os bolsistas fazem uma autoavaliação no relatório final da bolsa. O mesmo ocorre com os bolsistas do Espaço COPPE, que também são bolsistas de extensão da universidade.

Mauro, do MAST, também afirma que o relatório é o momento que os alunos têm para avaliarem sua formação e seu orientador. E declara que não há um outro momento específico para o bolsista realizar essa avaliação, o que seria válido, já que o aluno dificilmente faria críticas no relatório escrito.

No relatório tem um item em que se pede que ele avalie o programa, ou seja, ele pode até dizer, o pesquisador foi negligente, ele não me deu orientação, ele tem a liberdade de dizer isso. Claro que ele vai sofrer, digamos, as retaliações, mas que ele pode dizer, pode. Eu acho interessante isso porque é claro que um bolsista de graduação, que não tem tanta autonomia, é difícil fazer esse tipo de coisa, mas para nós seria muito interessante, daria, digamos, um elemento qualitativo muito importante para avaliar o programa, para avaliar por dentro, de uma outra perspectiva. - Mauro

Já César, também do MAST, diz que não há um momento formal para essa avaliação, mas considera que o fato dos alunos procurarem o estágio no museu através da divulgação boca a boca faz com que cheguem tendo uma noção de como é o trabalho que será realizado, proporcionando um 
bom ambiente de trabalho (e que, portanto, os bolsistas gostam). Os que não gostam, pedem para o desligamento do estágio.

Normalmente, se eles não estão satisfeitos, eles pedem para sair... mas é muito difícil eles não gostarem porque 0 ambiente aqui tem trabalho para fazer, mas eles... assim, o ambiente é muito bom, é bem... e quando eles vêm para cá eles já têm uma ideia do que que é. - César

É claro que, na verdade, o depoimento de César não é uma avaliação dos alunos, mas uma percepção em relação ao fato dos alunos gostarem ou não do estágio.

Ludmila, do ECV, explica que os alunos fazem uma avaliação ao final dos atendimentos ao público. Essa avaliação pode ser registrada em um caderno, e diversos aspectos sobre o atendimento são apontados como: se foi útil para eles, se ocorreu um problema, alguma demanda, situação atípica ou elogio. Esse registro é útil para as discussões com os mediadores seniores.

Já Fernando, do mesmo museu, explica que a avaliação dos bolsistas sobre o estágio é feita diretamente com os orientadores até porque é parte do relatório final da bolsa. Mas pondera que essa avaliação do relatório é um registro formal e que deveria haver um momento próprio para essa avaliação e que uma avaliação permanente evitaria problemas durante o processo formativo.

Em um relatório padrão de CAPES, CNPq, você sempre avalia o seu orientador, avalia o processo, o que você achou de dificuldades. Mas muitas vezes aquele relatório é um relatório mais formal, é só para ter um registro. Mas acho que nesse caso precisamos melhorar, que é poder ter mais formalmente no momento bimestral, ou semestral, ou mensal em que a gente realmente possa ouvir isso... porque senão muitas vezes acaba acontecendo realmente porque quando você vai ver tem algum problema (risos) sério envolvido ali e aí é avaliação permanente ela não serve para evitar essas situações - Fernando

Percebe-se, portanto, que os espaços para que o aluno avalie o processo, quando existentes, são em geral os mesmos para que os profissionais avaliem os alunos. Ou seja, quando o aluno avalia a formação que teve no estágio, ele o faz a partir dos relatórios, do diálogo direto com seu orientador e nas reuniões de equipe.

Ohayon e colaboradoras (2007) discutem que a avaliação da IC deveria fornecer subsídios para embasar o planejamento das atividades, repensar os critérios de seleção dos alunos e possibilitar a melhora da 
aprendizagem durante o estágio. Para tanto, a avaliação precisa ser feita de forma contínua durante o processo.

A partir dos depoimentos, é possível perceber que, mais uma vez, a exigência da avaliação no edital da bolsa faz com que essa prática seja realizada. Entretanto, a avaliação em relatório não garante que a formação do estagiário seja repensada ao longo do processo, pois ocorre de forma pontual e ao final do estágio.

Nesse sentindo, algumas instituições adotam práticas avaliativas que vão além da formalidade do aluno dedicar uma parte do relatório à avaliação do estágio e da orientação. Parte dos entrevistados indica ser necessário um outro espaço para a avaliação em que o aluno tenha mais liberdade de expressar sua percepção sobre o processo formativo.

É possível constatar nas falas de Anita (Museu Nacional), Eric (Museu da Vida) e Fernando (ECV) a compreensão de que são necessárias outras alternativas para que o aluno possa avaliar sua formação durante o estágio. Entretanto, apenas o setor educativo do Museu Nacional faz uma avaliação do processo de modo a investigar as expectativas e dificuldades dos bolsistas e repensar as estratégias utilizadas para a formação. No Museu da Vida há uma avaliação por parte dos alunos do PROPOP apenas durante as atividades de formação e dos alunos do Pró-Cultural de forma constante, durante todo o processo. No ECV há uma avaliação contínua, mas especificamente das atividades de mediação.

5.5 .

\section{A formação dos bolsistas nos demais museus de ciência do país}

A escassez de pesquisas que investigassem a participação de alunos em projetos de iniciação científica e extensão em museus levou a uma tentativa de mapeamento do estágio nos demais museus de ciência do país. Existem outros museus de ciência oferecendo bolsas para alunos de graduação e ensino médio? Que tipos de bolsas? Caso ofereçam bolsas, os processos formativos são semelhantes aos encontrados nos museus estudados?

Buscando então responder a essas indagações, foi elaborado um questionário online (Apêndice 3) enviado aos museus e centros de ciências 
cadastrados pela Associação Brasileira de Centros e Museus de Ciência (ABCMC). O questionário foi enviado às 291 instituições e respondido por 56 (19\%). A distribuição do número de museus e centros de ciência existentes por região e o número de respondentes encontram-se na Tabela 1. Os Estados que não possuem museus de ciência não foram listados na tabela.

Tabela 1: Número de museus existentes em cada região e Estado brasileiro e de instituições que responderam ao questionário.

\begin{tabular}{|c|c|c|c|c|}
\hline Região & Estado & $\begin{array}{c}\text { Total de } \\
\text { instituições }\end{array}$ & $\begin{array}{l}\text { Instituições } \\
\text { respondentes }\end{array}$ & $\begin{array}{c}\text { Instituições } \\
\text { que } \\
\text { possuem } \\
\text { bolsistas }\end{array}$ \\
\hline \multirow{5}{*}{ Centro-Oeste } & DF & 8 & 2 & 0 \\
\hline & $\mathrm{GO}$ & 4 & 0 & 0 \\
\hline & MS & 1 & 0 & 0 \\
\hline & MT & 3 & 1 & 1 \\
\hline & Total & 16 & 3 & 1 \\
\hline \multirow{9}{*}{ Nordeste } & $\mathrm{AL}$ & 3 & 1 & 1 \\
\hline & $\mathrm{BA}$ & 8 & 1 & 0 \\
\hline & $\mathrm{CE}$ & 9 & 1 & 1 \\
\hline & MA & 1 & 1 & 1 \\
\hline & PB & 3 & 1 & 0 \\
\hline & $\mathrm{PE}$ & 9 & 2 & 2 \\
\hline & $\mathrm{RN}$ & 5 & 2 & 1 \\
\hline & SE & 3 & 0 & 0 \\
\hline & Total & 41 & 9 & 6 \\
\hline \multirow{5}{*}{ Norte } & $\mathrm{AM}$ & 3 & 0 & 0 \\
\hline & AP & 2 & 0 & 0 \\
\hline & PA & 5 & 0 & 0 \\
\hline & $\mathrm{RR}$ & 1 & 0 & 0 \\
\hline & Total & 11 & 0 & 0 \\
\hline \multirow{5}{*}{ Sudeste } & ES & 7 & 0 & 0 \\
\hline & MG & 29 & 8 & 6 \\
\hline & RJ & 43 & 5 & 4 \\
\hline & SP & 93 & 19 & 14 \\
\hline & Total & 172 & 32 & 24 \\
\hline \multirow{4}{*}{ Sul } & PR & 20 & 5 & 3 \\
\hline & $\mathrm{RS}$ & 18 & 3 & 4 \\
\hline & SC & 13 & 4 & 3 \\
\hline & Total & 51 & 12 & 10 \\
\hline \multicolumn{2}{|c|}{ Total Geral } & 291 & 56 & 41 \\
\hline
\end{tabular}

Fontes: O número de instituições existentes foi cedido pela ABCMC e o número de respondentes é dado desta pesquisa.

Das 56 instituições respondentes, 41 declararam possuir alunos bolsistas. Destas, 40 afirmaram possuir bolsistas de ensino superior, sendo que cinco também informaram possuir bolsistas de ensino médio, uma revelou possuir bolsistas de pesquisa e uma de mestrado. 
Os dados da $A B C M C$ mostram que mais da metade dos museus de ciência está localizada na região Sudeste. Em relação ao número de bolsistas, os dados levantados a partir do questionário revelam que essa concentração se torna ainda maior, considerando-se que das 41 instituições que afirmaram possuir estagiários, 24 estão nesta região (58\%) (Gráfico 1). Esses dados reforçam a discussão de Damasceno (2002) em relação a distribuição desproporcional de bolsas PIBIC entre as grandes regiões brasileiras. No caso do PIBIC, a autora afirma que quase metade das bolsas são absorvidas por instituições localizadas na região Sudeste Gráfico 1: Total de instituições existentes, respondentes e com bolsistas por região geográfica brasileira.

— Instituições respondentes — Instituições que possuem bolsistas — Total de instituições

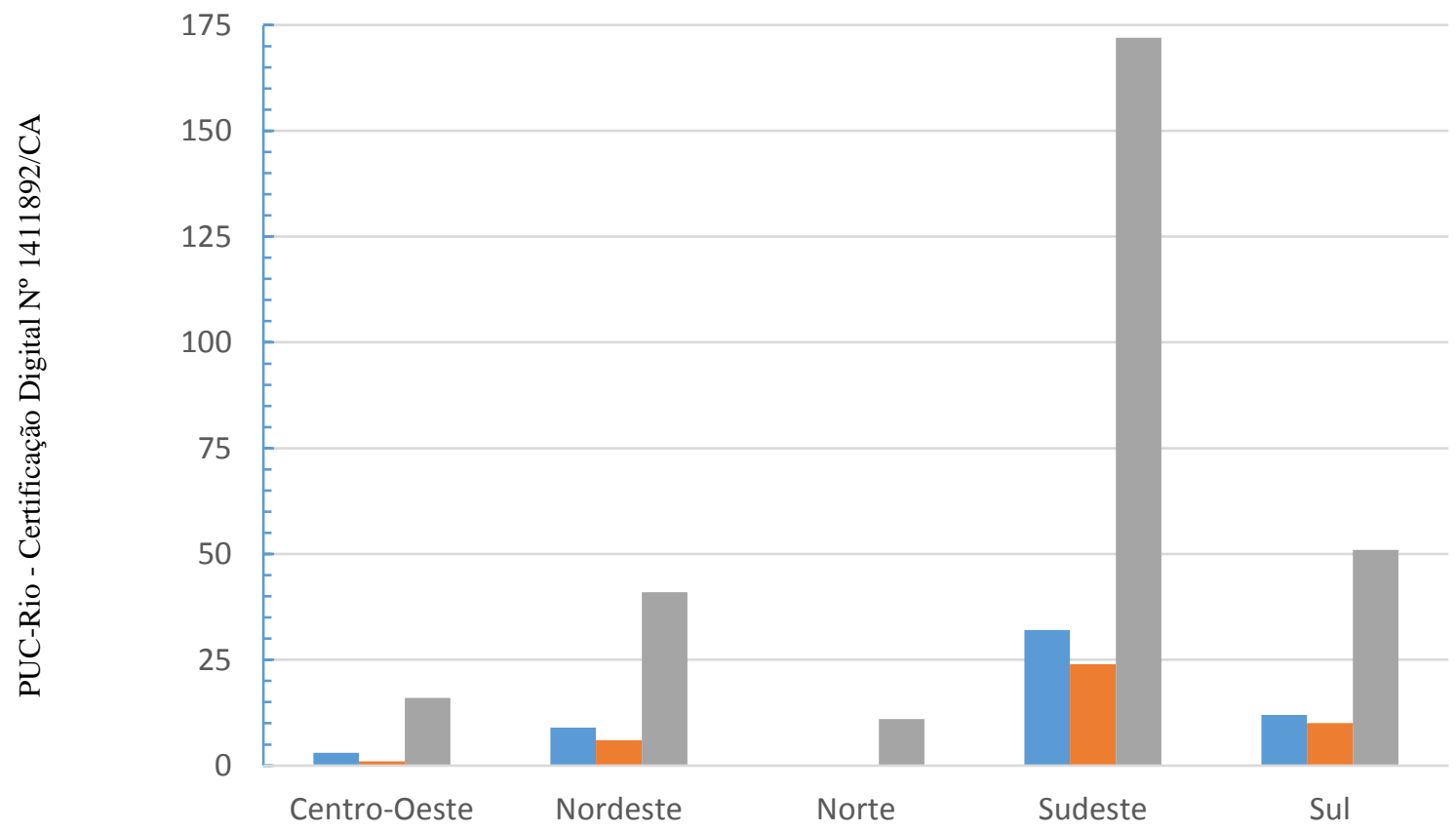

Fonte: Dados da pesquisa.

Damasceno (2002) relaciona a concentração das bolsas ao fato da região Sudeste ser o principal polo econômico do país, o que leva a uma concentração de universidades e centros de pesquisa. Mas chama atenção que, no caso dos museus, a proporção de bolsistas supera $50 \%$. É claro que não é possível generalizar, pois apenas 56 instituições responderam ao questionário.

Embora o questionário tenha tido uma taxa de resposta baixa, foi possível verificar uma aproximação entre as respostas fornecidas pelas 
instituições no questionário com as falas dos entrevistados dos museus da cidade do Rio de Janeiro.

A maior parte das instituições oferece bolsas de extensão universitária (24). Também são oferecidas bolsas de IC (10), apoio técnico (7), além de bolsas de outra natureza $(17)^{60}$ como esquematizado no Gráfico 2.

Gráfico 2: Tipos de bolsa ofertadas pelos museus que possuem alunos bolsistas

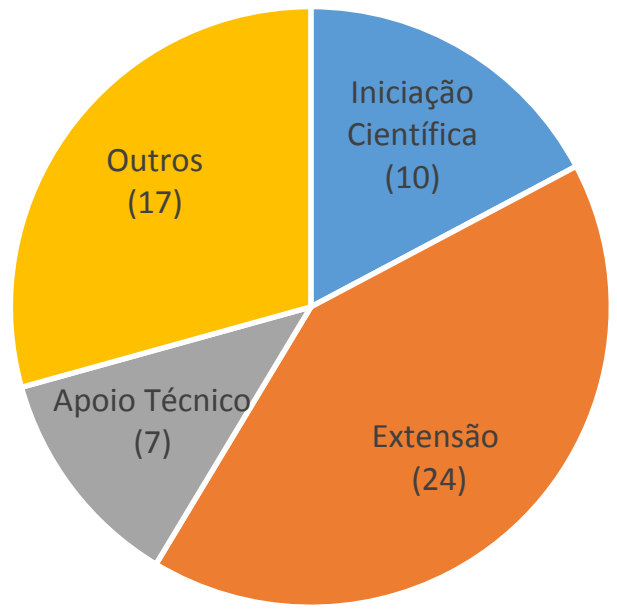

Fonte: Dados da pesquisa.

O tipo de cursos de origem dos alunos bolsistas de graduação é muito variado, sendo que os mais frequentes estão ligados às áreas de ciências da natureza, matemática e engenharias. Entre os mais citados estão61 Ciências Biológicas (citado 20 vezes); Engenharias ${ }^{62}$ (13); Física (7, uma licenciatura em Física); Química 6 (uma licenciatura em Química);

60 Os demais tipos de bolsas citadas e reunida na categoria "outros" são: estágio (4); CIEE (3); assistência estudantil (2); bolsa da fundação CECIERJ para mediadores de museus (1); auxílio carência (1); acadêmica (1); fundo de apoio acadêmico (1); foco acadêmico (1); monitoria (1); treinamento profissional (1) e pós-graduação (1)

61 Os demais cursos de graduação citados foram:

Cursos citados duas vezes: Antropologia; Ciências da Computação; Ciência e Tecnologia; Comunicação Social; Geologia; Veterinária.

Cursos citados apenas uma vez: Administração; Agronomia, Arquitetura; Artes; Artes Visuais; Artes Cênicas; Biblioteconomia; Biofísica; Ciências Biológicas - Modalidade Médica; Ciências Matemáticas e da Terra; Ciências Sociais; Ciências Socioambientais; Conservação e Restauro; Design; Ecologia; Estatística; Farmácia-Bioquímica; Filosofia, Gravura; Geociências (licenciatura); Gestão Ambiental; Letras-Libras; Metrologia; Oceanografia; Tecnólogo em radiologia; Terapia Ocupacional.

62 Cursos de Engenharia citados: Engenharia Acústica; Engenharia Aeroespacial; Engenharia Agrícola e Ambiental; Engenharia Ambiental; Engenharia de Agrimensura; Engenharia Civil; Engenharia Elétrica; Engenharia Florestal; Engenharia Química; Engenharia Sanitária e Ambiental 
Matemática (5). Os cursos de História (7); Geografia (5), Pedagogia (4) e Turismo (3) também são citados por algumas instituições.

O fato de haver um predomínio de alunos de cursos de graduação de Ciências da Natureza, Matemáticas e Engenharias parece estar associado a um interesse dos museus por estagiários que tragam de seus cursos universitários o que Cazelli e Gomes (2015) chamam de saberes disciplinares.

Cinco museus afirmaram que o estágio é aberto a todos os cursos de graduação (dois deles estão ligados a universidades), dois declararam que oferecem as bolsas para alunos das licenciaturas em ciências em geral, e um museu informou que disponibiliza para alunos dos cursos de ciências exatas e da terra.

Em relação aos critérios de seleção dos bolsistas, 35 afirmaram que o interesse pelo trabalho é muito importante, assim como a disponibilidade de horário (21 - muito importante; 16 - importante).

O coeficiente de rendimento dos alunos parece importar menos para a seleção. (3 - não é levado em consideração; 8 - pouco levado em consideração; 13 - média; 6 - levado em consideração; 10 muito levado em consideração).

Esses dados são semelhantes ao levantado pelas entrevistas e mais uma vez contrariam a reflexão de Brid e Pereira (2004) de que há uma seletividade a partir do mérito acadêmico. É claro que é importante ponderar que a reflexão desses autores é sobre as atividades de IC especificamente e não sobre os estagiários de graduação em geral.

A maior parte das instituições afirmou que os alunos bolsistas apresentam os resultados do estágio (31 sim e 6 eventualmente), principalmente na forma de relatórios e através da participação de eventos científicos e jornadas acadêmicas (Tabela 2). Na opção "outros" foi citado: apresentando seminário, apresentando para a equipe, desenvolvendo atividades educativas, pelo desempenho de trabalho.

Como discutido anteriormente, a escrita e a apresentação de resultados são parte fundamental da formação em espaços de produção do conhecimento. Além da escrita, a possibilidade da participação em 
eventos faz com que o aluno compreenda a importância da socialização do conhecimento e da socialização com pares (MASSI e QUEIROZ, 2015).

Tabela 2: Formas de apresentação dos resultados do estágio nos museus e centros de ciência investigados

\begin{tabular}{l|c}
\hline Forma de Apresentação dos Resultados & Número Total de citações \\
\hline Elaboração de Relatórios & 31 \\
\hline Eventos Científicos & 21 \\
\hline Jornadas Acadêmicas & 18 \\
\hline Publicando em Periódicos Científicos & 6 \\
\hline Publicando em Revistas de divulgação & 6 \\
\hline Outros & 4 \\
\hline
\end{tabular}

Fonte: Dados da pesquisa.

A avaliação dos bolsistas também é realizada pela maioria das instituições respondentes (30 sim e 4 eventualmente). As formas mais citadas de avaliação foram a elaboração de relatórios e as reuniões de equipe (Tabela 3). Na opção "outros" foi citado: acompanhamento do trabalho, alcance de metas propostas, confecção de artigo, através de ficha de avaliação de estágio da universidade.

Tabela 3: Formas de avaliação dos bolsistas nos museus e centros de ciência investigados

\begin{tabular}{l|c}
\hline \multicolumn{1}{c|}{ Forma de Avaliação } & Número de citações \\
\hline Relatório Escrito & 22 \\
\hline Parecer de Avaliadores externos & 3 \\
\hline Reunião da equipe de orientadores & 14 \\
\hline Outros & 5 \\
\hline
\end{tabular}

Fonte: Dados da pesquisa.

A oportunidade dos alunos avaliarem o estágio foi menos comum do que a da instituição avaliar os bolsistas. 19 instituições afirmaram que os alunos têm a possiblidade de fazer essa avaliação; 7 eventualmente; 14 não. Quando o aluno avalia, as formas mais citadas são a autoavaliação e os relatórios escritos. (Tabela 4)

Tabela 4: Formas que os alunos bolsistas têm de avaliar seu estágio nos museus e centros de ciência investigados

\begin{tabular}{l|c}
\hline \multicolumn{1}{c|}{ Forma de Avaliação } & Número de citações \\
\hline Autoavaliação & 13 \\
\hline Relatório Escrito & 12 \\
\hline $\begin{array}{l}\text { Reuniões com os orientadores ou com a } \\
\text { equipe }\end{array}$ & 7 \\
\hline
\end{tabular}

Fonte: Dados da pesquisa.

Os dados sobre a avaliação também se aproximaram do encontrado a partir das entrevistas, uma vez que a avaliação se dá predominantemente 
por relatórios e pela avaliação dos orientadores e a avaliação feita pelos alunos sobre o processo é menos frequente.

A partir das respostas dos questionários não é possível compreender se essa avaliação é pontual, ou ocorre ao longo do processo, permitindo o replanejamento do estágio e a melhora da aprendizagem, como indicado por Ohayon e colaboradoras (2007).

Em relação aos museus que afirmaram não possuírem alunos bolsistas, as principais causas apontadas foram a falta de verbas e de bolsas. Nenhuma instituição respondente declarou que não deseja possuir alunos bolsistas em seus quadros. Na opção "outros" foi citado: espaço de educação não formal e presença de estagiários remunerados que substituem os bolsistas na mediação (Tabela 5).

Tabela 5: Causas apontadas pelos museus e centros de ciência investigados para a ausência de alunos bolsistas

\begin{tabular}{l|c}
\hline \multicolumn{1}{c}{ Causas para a ausência de bolsistas } & Número de museus \\
\hline $\begin{array}{l}\text { Falta de verbas para o desenvolvimento de } \\
\text { projetos }\end{array}$ & 9 \\
\hline Falta de bolsas & 3 \\
\hline $\begin{array}{l}\text { Falta de profissionais para orientar os } \\
\text { bolsistas }\end{array}$ & 1 \\
\hline Falta de alunos interessados & 2 \\
\hline Outros
\end{tabular}

Fonte: Dados da pesquisa.

Considerando que a falta de verbas e bolsas se configurou como motivo para a ausência dos estagiários nos museus, cabe destacar a importância das agências de fomento como o CNPq e as Fundações Estaduais, para que seja possível a viabilização da formação na IC (MASSI e QUEIROZ, 2010) e de verbas para que as universidades promovam editais de financiamentos de bolsas de extensão universitária e de apoio estudantil.

A partir dos dois recursos metodológicos utilizados para 0 desenvolvimento desta pesquisa, foi possível conhecer melhor os tipos de estágio realizado por alunos bolsistas em museus de ciência. As respostas do questionário se aproximaram das respostas das entrevistas sobre as formas mais comuns de seleção dos bolsistas, apresentação de resultados da pesquisa, avaliação (pela instituição e pelo estagiário). No próximo 
capítulo, serão discutidas as dimensões formativas encontradas nessas instituições. 


\section{6. \\ Os processos formativos encontrados no estágio em museus de ciência}

No capítulo anterior, foram descritas as etapas presentes no estágio de alunos bolsistas em museus de ciências. Com o intuito de compreender a natureza desse estágio, foram investigados e descritos os critérios de seleção, as atividades desenvolvidas, a participação dos alunos em jornadas e outros eventos científicos e as formas de avaliação do estágio (por parte da instituição e do próprio aluno).

Neste capítulo, serão discutidas as dimensões formativas percebidas nas falas dos entrevistados. O objetivo é entender quais os significados formativos da iniciação científica e da extensão universitária em geral e nos espaços investigados em particular. Também serão exploradas as interfaces percebidas entre o estágio e a atuação dos alunos como mediadores, o que é uma particularidade do estágio nos museus e espaços e expositivos.

\section{1.}

\section{A interface do estágio com a mediação - o museu como espaço para a formação de educadores}

Um dos aspectos investigados sobre o estágio dos alunos nos museus foi se os bolsistas necessariamente atuavam como mediadores da exposição e nas demais atividades educativas e, caso atuassem, se esse papel como mediador se relacionava às outras atividades do estágio, ou se era apenas mais uma das tarefas a ser cumprida, sem relação com as demais, como a pesquisa, por exemplo.

A partir do questionário, foi possível perceber que a maior parte dos bolsistas que atuam nos museus brasileiros de ciência também atuam como mediadores (dos 41 museus que indicaram no questionário possuir alunos bolsistas; 29 afirmaram que eles atuam como mediadores; 9 que atuam eventualmente e 3 que não atuam). 
Gomes e Cazelli (2016) destacam que, na prática, os mediadores comumente podem se dedicar a distintas tarefas no museu. Essas tarefas podem estar relacionadas ao atendimento ao público, como o diálogo com os visitantes; a orientação para o uso de aparatos interativos nas exposições; a recepção de grupos agendados; a participação em atividades artísticas como peças de teatro. $\mathrm{O}$ envolvimento com tarefas variadas durante a mediação foi constatado na fala dos entrevistados sobre as atividades desenvolvidas pelos bolsistas descritas no capítulo anterior. Porém, a ideia desta seção não é investigar cada uma dessas tarefas, mas sim entender se, quando existente, a atividade de mediação está associada à iniciação científica e/ou à extensão, dimensões formativas que serão aprofundadas nas seções seguintes.

No Museu Nacional, como já explicado, os alunos de graduação que são bolsistas de IC realizam pesquisas nos diferentes departamentos como a Botânica, Zoologia (Invertebrados, Vertebrados), Paleontologia (entre outros) e não participam dos processos de mediação junto à exposição. Essa tarefa cabe aos alunos bolsistas PDI que são ligados ao setor educativo. Pela fala de Anita, entende-se que essa bolsa não determina que $\mathrm{o}$ aluno desenvolva um trabalho associado à pesquisa. $\mathrm{O}$ trabalho desse grupo, segundo a entrevistada, tem um caráter extensionista e o bolsista pode atuar apenas nas atividades de mediação.

Em relação aos alunos de ensino médio ligados ao setor educativo, os que fazem estágio voluntário atuam apenas nas atividades de mediação. Os que recebem bolsa Jovens Talentos da FAPERJ, como já discutido, têm que desenvolver uma pesquisa, por se tratar de uma bolsa de IC-EM. Assim, a partir do momento em que passam a receber a bolsa, os alunos se inserem em alguma das linhas de pesquisa em educação museal que a Seção de Assistência ao Ensino (SAE) desenvolve. As pesquisas podem dialogar direta ou indiretamente com as atividades de mediação.

No Museu da Vida, todos os bolsistas de graduação atuam na mediação e essa atuação está ligada ao processo de formação. Segundo Eric, toda a formação é interligada, ou seja, se há um momento da formação em que seja discutida a questão da comunicação em museus, 
necessariamente estará relacionado à mediação, correlação que ocorrerá para todos os demais temas discutidos nos processos de formação.

Os alunos de ensino médio, bolsistas do Pró-Cultural, não atuam nas atividades de mediação de forma direta com o público do museu, mas podem atuar na produção dessas atividades. Marina explica que caso haja uma peça de teatro, por exemplo, eles podem trabalhar na produção de textos, cenários, figurinos, ou mesmo na direção.

Além das exposições serem uma atividade cultural, temos várias outras atividades que o museu faz que eles podem participar, como ajudando na produção daquela atividade para que aquela atividade aconteça. - Marina

No Museu da Química, todos os bolsistas atuam na mediação. Quando não estão ocupados com as atividades de mediação, eles se envolvem com atividades de preservação e manutenção do acervo. Mas os bolsistas (de extensão) não participam da elaboração das exposições, o que, segundo Antônio, é realizado por ele e por outros professores e funcionários da universidade.

Em relação aos bolsistas PIBIC do MAST, a participação nas atividades de mediação acontece quando o bolsista está ligado ao setor educativo. Como já explicado, o MAST está dividido em coordenações. A coordenação de educação (COEDU) realiza pesquisas sobre divulgação científica e popularização da ciência. Entretanto, Mauro explica que a coordenação de museologia também atua nos processos de mediação, uma vez que participa das etapas de elaboração e manutenção das exposições.

[...] não só a mediação no museu especificamente, na exposição, mas digamos, na divulgação e na educação científica. Essa é a missão mais direta dessa coordenação [de educação], a de divulgação científica, popularização de ciências, inclusão social pela ciência, essa é a área que eles trabalham mais diretamente. Inclusão, todos nós trabalhamos um pouco, mas a centralização disso está na educação. [...] A mediação, no sentido educativo do termo, também é feita pela coordenação de museologia, que é responsável pelas exposições, é a responsável técnica pelas exposições, não necessariamente como curadoria, mas todas as exposições são feitas com o aval e a partir da coordenação de museologia. Então ela faz uma intermediação no sentido em que ela está pegando um produto de pesquisa e transformado isso numa linguagem expositiva. Mauro

Aqui é importante pontuar que a mediação se refere a todas as formas ou mecanismos que facilitam a ligação entre o visitante e a exposição e não 
apenas à mediação feita por pessoas. A mediação também pode ocorrer na forma de textos, objetos mediadores, nas escolhas da curadoria, e não somente na ação direta dos educadores com o público (FERREIRA, 2014). Entretanto, como discutido no capítulo 4, muitos autores valorizam a mediação humana, pois esta parece ser a forma que melhor garante que a mensagem idealizada na elaboração da exposição seja compreendida pelo público (MARANDINO, 2008). Além da importância que a mediação humana tem na literatura sobre o tema, como o objetivo desta pesquisa é investigar a formação e atuação dos alunos bolsistas nos espaços museais, o interesse aqui é, portanto, refletir sobre o diálogo desse papel de mediador com as demais atividades desenvolvidas pelos alunos.

Neste contexto, cabe também destacar que os bolsistas que atuam como mediadores na exposição e demais atividades junto ao público no MAST são apenas os bolsistas do setor educativo. Ao indagar ao coordenador do setor se as atividades de mediação e pesquisa se relacionam ou se são paralelas, ele esclareceu que, sempre que possível, as atividades se relacionam e que um bolsista que é ligado a uma atividade, em geral, realiza pesquisas focadas em sua implementação e avaliação.

No Espaço COPPE, todos os bolsistas atuam como mediadores. Como já explicado, a exposição então aberta ao público no momento desta pesquisa não foi criada pelos funcionários do museu, portanto, não teve a participação dos bolsistas, mas eles participam da elaboração das oficinas oferecidas fora do museu. Não há entretanto nenhuma pesquisa desenvolvida pelos bolsistas ao longo do processo.

Por fim, no ECV, todos os bolsistas participam das atividades de mediação com o público. Cada mediador também integra subgrupos que pesquisam temas específicos, como sexualidade e ensino de matemática. $\mathrm{Na}$ fala de Ludmila e de Fernando, é possível compreender que todos os processos (mediação, formação e pesquisa) são interligados. Fernando explica que o fato do projeto institucional englobar ações de extensão universitária que ocorrem em um museu faz com que os bolsistas tenham uma formação que envolve saberes sobre gestão, planejamento, educação em espaços não formais e mediação. $O$ entrevistado também considera 
que é no desenvolvimento de atividades e materiais que se dá o processo de pesquisa.

[...] parte [da formação] é estudar e participar dos debates que temos aqui sobre mediação em museu, o que que é educação não formal, quer dizer, entender um pouco o que é esse espaço, como ele se diferencia do espaço escolar. Tanto que umas das dificuldades que nós temos na formação é que exatamente, o mediador, ele entender qual é a função dele aqui. Porque ele não é um professor explicador que vem aqui dar uma aula. Então o museu, ele tem uma natureza diferente. Então faz parte do processo de formação dele entender esse processo e ele faz isso muito em cima da prática e das nossas reuniões de estudo e reflexão. Mas mesmo que seja uma sala pequena eles estão sempre envolvidos na organização e na produção de algum material didático, de algum módulo, então isso é o que caracteriza essa pesquisa de iniciação, digamos, no museu. - Fernando

É possível perceber então que, nesse universo de museus, existem processos de formação que podem não dialogar com a mediação, como no Museu Nacional e no MAST, onde os bolsistas de IC que fazem estágios em alguns setores não necessariamente dialogam com a produção de conhecimento sobre mediação e educação museal e não atuam como mediadores na exposição ou qualquer outra atividade educativa realizada pelo museu. No caso do Museu Nacional, os bolsistas que não fazem estágio no setor educativo, em sua maioria, não realizam nenhum tipo de aproximação dos seus estágios com qualquer questão sobre educação. Já no MAST, bolsistas ligados ao setor educativo e de museologia podem ter pesquisas associadas à mediação, como a produção de materiais ou a curadoria, mas não atuam na mediação humana.

Nestes museus, cabe, portanto, aos bolsistas do setor educativo atuarem como mediadores junto ao público. No MAST, como os bolsistas do educativo são bolsistas de IC, também precisam estar ligados a uma pesquisa, e é desejável que ela se relacione com as atividades de mediação realizadas. De acordo com Gomes e Cazelli (2016), a relação entre a pesquisa acadêmica e a prática educativa perpassa a formação de mediadores no MAST, o que se relaciona com as próprias finalidades da Coordenação de Educação, onde os estudos acadêmicos em educação e museus e temas correlatos são realizados desde 1996 com o objetivo, inclusive, de avaliar suas próprias atividades educacionais.

Já no Museu Nacional, o fato da bolsa dos estagiários de graduação do setor não ser uma bolsa de IC faz com que não haja uma 
obrigatoriedade de desenvolvimento de uma pesquisa relacionada a sua atuação como mediador, mas há incentivo para que esse aluno seja um pesquisador da própria prática. Anita, responsável pelo setor, vê a atuação na mediação e a pesquisa como dois aspectos que devem ser relacionados. Os bolsistas de ensino médio também atuam na mediação e, por exigência da bolsa de IC, necessariamente se envolvem em pesquisas. Essas pesquisas são sobre educação museal e se relacionam com as atividades de mediação, mesmo que não sejam diretamente sobre a mediação, como ocorre, por exemplo, em estudos sobre público.

Nos Museu da Vida e ECV toda a formação dos alunos bolsistas parece estar interligada. Suas atividades envolvem a formação em educação museal, difusão e popularização da ciência, pesquisa e produção de materiais, atividades educativas e mediação. Entretanto, os alunos bolsistas de ensino médio do Pró-Cultural (Museu da Vida) são exceção, na medida em que possuem uma formação para a produção cultural que não envolve diretamente a mediação. Os bolsistas também não desenvolvem uma pesquisa com produção de conhecimento sobre o tema. A formação desse grupo, embora dialogue com conhecimentos sobre difusão e popularização da ciência, não é voltada para a formação de pesquisadores nessa área.

É interessante perceber que a concepção de formação de mediadores demonstrada pelos formadores do Museu da Vida, do ECV e por Anita, do setor educativo do Museu Nacional, se aproxima daquela defendida por Rodari e Merzagora (2007), que afirmam que um mediador deve ser envolvido nas etapas de planejamento das atividades oferecidas pela instituição, avaliar os objetivos e resultados do trabalho realizado. Há um diálogo também com a reflexão desenvolvida por Marandino (2008) e Queiroz e colaboradoras (2002) de que é preciso considerar na formação do mediador uma reflexão teórica que envolva saberes ligados à educação em museus e espaços não formais.

Já no Museu da Química e Espaço COPPE, os alunos bolsistas de extensão parecem atuar apenas na mediação junto ao público, uma vez que não há o envolvimento desses bolsistas em projetos de pesquisa ou o mesmo tipo de formação descrita pelos museus anteriores. O Museu da 
Química, no passado, já teve bolsistas de IC que investigavam o acervo, mas os bolsistas atuais têm como tarefa apenas sua manutenção e preservação e não participam da elaboração ou avaliação das atividades educativas. No Espaço COPPE, embora os bolsistas não tenham participado da concepção da exposição permanente, o grupo é envolvido na elaboração das atividades que são realizadas fora do museu. Nas falas dos entrevistados, não é possível perceber uma preocupação com uma formação que dialogue com os elementos de uma pedagogia museal, que entende que um mediador deva participar de todas as etapas do processo educativo, desde a concepção de uma atividade ou exposição, passando pela implementação, até chegar na avaliação das visitas.

O que é possível concluir é que a interface entre a mediação, a formação e as atividades de pesquisa podem ser influenciadas por três fatores: a natureza da bolsa, as concepções dos coordenadores sobre educação em museus e a organização setorial de cada instituição. Há instituições em que uma divisão setorial clara faz com que caiba ao setor educativo o planejamento e realização das atividades de mediação humana, como no Museu Nacional e no MAST. Quando os bolsistas do setor educativo são bolsistas de IC, necessariamente precisam se vincular a uma pesquisa e, nesses casos, a pesquisa em geral dialoga com as atividades de mediação, mesmo que indiretamente, pois envolverá sempre questões ligadas à educação museal. Se a bolsa não é de IC, o envolvimento do aluno na pesquisa depende da formação dos profissionais, quando a formação, ou prática profissional dos responsáveis é ligada à área de educação em museus, esse é um aspecto que parece influenciar no fato de que a formação do aluno contemple três eixos: ensino, pesquisa e mediação. Um outro fator é que essa formação em três eixos seja vinculada a um projeto institucional, como no Museu da Vida, que criou um programa de formação próprio que envolve essas três dimensões na formação para a difusão e popularização da ciência. O mesmo ocorre no ECV, que atua a partir de um projeto extensionista, mas que possui em seu quadro formadores que entendem que esses três aspectos devem caminhar juntos. 
As falas de alguns entrevistados também evidenciaram a compreensão de um diálogo do estágio nos museus com a formação inicial de professores. O curioso é que essa temática não era objeto de investigação desta pesquisa, e nem há perguntas no roteiro de entrevista que busquem compreender essa dimensão formativa nos museus. Entretanto, alguns entrevistados ressaltaram esse papel formativo, em especial quando indagados sobre a existência de alunos bolsistas na instituição. Frente à pergunta, além do destaque à presença do bolsista para a instituição, também fizeram uma reflexão sobre a importância do estágio para os alunos, relacionado essa etapa com a formação de professores e de educadores de espaços não formais. A seguir, será realizada então uma reflexão sobre o papel desse estágio na formação de professores em diálogo com autores do campo da educação em museus, buscando, assim, compreender as falas dos entrevistados. Não se pretende, portanto, dialogar aqui com autores do campo da formação de professores.

Embora os museus sejam reconhecidos como um espaço educativo, e o papel de educador em museus seja muitas vezes desempenhado, como verificado no capítulo anterior, por profissionais oriundos de diferentes cursos de graduação, a literatura sobre a formação de professores e educadores em museus e em espaços não formais de educação ainda é escassa no país, com relatos isolados de atividades em poucas instituições. Por outro lado, no campo da formação de professores em geral há uma ampla literatura que permite identificar modelos de formação já bastante consolidados e praticados ao longo de décadas no Brasil (JACOBUCCI, JACOBUCCI e NETO, 2009).

Queiroz (2002) ressalta que, no que se refere à formação de professores, os saberes docentes constituem objeto de estudo de quase todas as correntes de pesquisa voltadas para o ensino-aprendizagem. Como discutido no capítulo 4, Queiroz e colaboradoras (2002) encontraram na prática de mediadores a mobilização de saberes que se relacionam com os saberes escolares e com os saberes da educação em ciências. Além disso, os autores perceberam saberes que marcam mais fortemente a 
mediação museal, mesmo que ainda exista uma correspondência com o reduto escolar.

Avançando nessa reflexão teórica sobre os saberes mobilizados na atuação de mediadores em museus de ciência, Gomes e Cazelli (2014; 2016) propõem a utilização do conceito de saberes docentes de Tardif (2010) para discutir a formação de mediadores.

Esses trabalhos entendem os museus como espaço para a formação inicial de professores, tanto no que se refere à formação de mediadores ou educadores de museus que, como destacado anteriormente, acabam se formando com a prática, quanto para a formação de professores que irão atuar como professores da educação básica, mas com uma compreensão de que a educação ocorre no diálogo entre diferentes espaços educativos.

Nesse sentido, Queiroz (2002) ressalta que, seja para formar professores que atuarão nas escolas ou como mediadores de museus, é preciso entender que essa formação implica em

[...] construir discursos racionais, estéticos, técnicos e emocionais, sistematizados, sobre as certezas mesmo que provisórias, apesar de se reconhecer o futuro não determinista, imprevisível das ações educativas. Esses discursos podem ser compartilhados por uma rede mais ampla de profissionais que se questionem constantemente, procurando divulgar e validar o conhecimento construído por eles e se atualizar em relação às construções feitas por outros elementos dessa rede, fortalecendo e aumentando as ligações entre eles. (Queiroz, 2002, p. 85)

Em pesquisa realizada a partir de questionário aplicado a licenciandos que estagiavam em museus e centros de ciência no Rio de Janeiro, Barros e Silva (2011) perceberam que as categorias mais frequentes, apontadas pelos alunos em relação ao estágio, eram a possibilidade de experiência profissional e de ampliação do conhecimento científico. Contudo, poucos são os alunos de licenciaturas que realizam esse tipo de estágio ou têm contato com a educação em museus ao longo de sua formação. As autoras entendem que os resultados indicam que é preciso estimular alunos de licenciaturas a

[...] adotarem práticas culturais que estejam vinculadas a equipamentos culturais como museus e centros de ciência a fim de que tais equipamentos possam ser vistos como ferramentas pedagógicas em suas práticas docentes no futuro (BARROS e SILVA, 2011, p. 7).

Ao analisar as entrevistas realizadas para o desenvolvimento desta pesquisa, percebe-se que parte dos sujeitos entrevistados concorda com 0 
indicado por Barros e Silva (2011), no sentido que esses profissionais entendem que o estágio no museu possibilita ao aluno perceber os espaços de educação não formal como um local para a atuação profissional. É possível constatar esse aspecto na fala de Anita, do Museu Nacional:

A formação de professores é para atuação do educador no âmbito da educação formal e essa questão de educação não formal ou de educação museal ainda é pouco, na minha opinião, discutida e contemplada na formação de educadores, tanto de pedagogos quanto de licenciando, e aí eu acho que essa é uma contribuição interessante que o Museu oferece para esses estudantes, perceber que como educadores e licenciados não têm só o universo da escola ou da universidade como espaço de atuação como professores em sala de aula, mas que eles podem atuar como educadores em outros espaços. Então eu acho que é interessante também o museu e o setor educativo estar aberto para esses estudantes como bolsistas, oferecendo essa formação. - Anita

Outro aspecto destacado por Fernando, um dos entrevistados do Espaço Ciência Viva, é a possibilidade de que o aluno tenha uma "outra visão sobre a ciência". Da ciência como construção social, ou como indicado nas falas dos entrevistados, uma ciência cidadã e um ensino de ciências que se dê como uma ação social que sai de quatro paredes, voltada para o público e para uma formação científica crítica.

As falas dos entrevistados também se aproximam da pesquisa de Queiroz, Krapas e Valente (2002) quando os formadores afirmam que o estágio nos museus é uma possibilidade para que o aluno tenha contato com saberes que não estão presentes na sua formação no curso de graduação.

É interessante perceber que há também uma compreensão de que, mesmo que esse aluno bolsista mais tarde não atue profissionalmente como educador de museus, esse tipo de formação é importante para a sua atuação como professor nas escolas. Para Gomes e Cazelli (2016)

[...] os saberes da experiência construídos durante a atuação de professores em formação nos museus de ciência, incluindo a aplicação de saberes disciplinares em um novo contexto educacional, possibilita uma diversificação de seu repertório de saberes, o que pode refletir qualitativamente em suas práticas pedagógicas em contextos de educação formal (GOMES E CAZELLI, 2016, p. 20).

Além disso, as autoras entendem que o contato com saberes da formação profissional, específicos da educação em museus, durante a formação de mediadores também contribuirá para a formação de futuros professores, pois fornece um embasamento teórico que possibilita que os 
futuros professores utilizem com seus alunos os espaços não formais de educação com maior autonomia.

Fernando, do Espaço Ciência Viva, faz uma reflexão semelhante à de Gomes e Cazelli (2016), considerando que a experiência no museu possibilitará que os bolsistas, que por ventura, no futuro, optem pela atuação profissional em espaços de educação formal, sejam professores mais criativos e que reconhecerão os espaços de educação não formal como locais para a formação de seus alunos.

Acreditamos que isso [o estágio no museu] é essencial para a formação deles como futuros professores, tanto na prática que acreditamos que as nossas atividades têm, possibilitam ter uma dinâmica melhor em sala de aula, inclusive temos um curso de formação de professores que preza isso: a metodologia do museu empregada para os professores desenvolverem em sala de aula, mas também a possibilidade deles perceberem que aqui é um espaço que eles podem voltar como visitantes, com os alunos. Sempre trabalhamos a ideia da ciência cidadã, em que objetivo é esse, que tanto eles, quanto os alunos deles se apropriem do espaço porque o espaço é para eles. Notamos que um aluno que foi mediador é um professor muito diferente quando vai para a sala de aula, é muito, muito, muito diferente. Fernando

A análise das falas das entrevistas permite perceber que a mediação é uma dimensão importante no estágio em museus, mas que sua relação com as demais atividades varia muito entre as instituições e de acordo com a concepção de educação em museus dos formadores. Os museus em que as atividades de mediação, pesquisa e extensão estão relacionadas são também aqueles em que os formadores manifestaram uma percepção de que há um diálogo do estágio com a formação de professores, seja para atuarem como educadores de espaços não formais ou mesmo como professores da educação básica. As dimensões formativas relacionadas à pesquisa e à extensão universitária serão melhor exploradas nas seções a seguir.

\section{2 .}

\section{A Iniciação Científica e a formação de pesquisadores}

No primeiro capítulo deste trabalho, foi realizado um esforço teórico com o intuito de compreender o que há de próprio no conhecimento científico e de que forma se estabeleceu uma comunidade científica, em especial, a(s) comunidade(s) de pesquisadores brasileiros. No segundo capítulo, foi abordado aspectos relacionados à Iniciação Científica, 
ressaltando-se o quanto essa ação, como política de formação de pesquisadores, é fruto da história da constituição dessa comunidade no país e da necessidade de se aumentar os quadros de profissionais nas áreas científicas, buscando encurtar o tempo de formação dos pesquisadores.

Considerando o objeto desta pesquisa, talvez uma das perguntas centrais deva ser o que significa iniciar um jovem em um campo científico. Para Neves (2007), há uma escassez de debates sobre a formação de pesquisadores no campo da educação. A partir do diálogo com autores dos campos da epistemologia da ciência, sociologia e antropologia, propõe que se reflita sobre uma pedagogia da pesquisa.

A autora se baseia em autores como Kuhn, Latour e Bourdieu para entender e fazer proposições sobre os significados do que seria essa pedagogia, que envolveria as etapas e processos que ocorrem na formação dos pesquisadores e na iniciação de jovens nos campos e tradições da ciência.

Como discutido no capítulo 2, a epistemologia da ciência contribui pouco para o entendimento do que significa formar um pesquisador, na medida em que se preocupa mais em explicar o que a ciência é e não sobre como ela é, ou seja, considera muito pouco o papel das práticas e dos sujeitos envolvidos na produção do conhecimento científico.

Dentre os filósofos da ciência, Thomas Kuhn talvez tenha sido o que mais contribuiu para o entendimento acerca da entrada de um novo membro na comunidade científica. Com sua divisão funcionalista sobre as atividades científicas, compreende que o novo membro se insere para a prática da ciência normal, onde o aluno iniciante será disciplinado dentro de práticas através da leitura dos manuais escritos sob um paradigma vigente.

Entretanto, Neves (2007) destaca que "o mero estudo da teoria não torna o estudante um ativo produtor das ciências, não assegura a formação de um praticante das ciências, um cientista enfim" (NEVES, 2007, p. 5). A autora discute que Kuhn não traz elementos que ajudem a entender as práticas e atividades cotidianas dos cientistas. 
Nesse sentido, os Estudos de Laboratório podem auxiliar mais na reflexão sobre a pedagogia da pesquisa, pois ajudam a entender as práticas dos pesquisadores e não apenas o que eles entendem como Ciência. Como discutido no capítulo 2, o trabalho etnográfico de Latour é considerado o primeiro e um dos principais trabalhos dentro dos Estudos de Laboratório. A pesquisa de Latour foi original no sentido de enfrentar o desafio de compreender como a ciência, considerada por ele uma prática de construção de enunciados e de argumentação persuasiva, se assemelha e se difere de outras práticas sociais (KROPF e FERREIRA, 1998). Para Latour e Woolgar (1997), é preciso observar as práticas para que se tenha uma análise independente sobre a ciência, não sendo possível se basear unicamente no que os pesquisadores dizem sobre si mesmo.

Os Estudos de Laboratório avançaram na compreensão sobre o fazer científico, na medida em que consideram que para o entendimento dessas atividades é preciso levar em conta diversos fatores, como o local de trabalho (infraestrutura); os sujeitos envolvidos (pesquisadores, estudantes e demais trabalhadores); as teorias, modelos e outras representações tácitas ou explicitas; os materiais e equipamentos usados na pesquisa; as formas de financiamento; entre outros (MATTEDI, 2007).

Para Neves (2007), os Estudos de Laboratório são úteis para a compreensão dos processos de formação de pesquisadores, pois evidenciam as práticas, dando materialidade à ciência, ao invés de um tratamento abstrato. A autora considera que essas práticas constituem um ambiente específico - o laboratório - e características específicas desse ambiente tornam possíveis as operações e diálogos entre os sujeitos envolvidos na atividade científica. Aqui cabe ressaltar, como discutido por Mattedi (2007), que nem todo conhecimento científico é produzido em laboratórios e que o termo "laboratório" nesses Estudos simboliza a atividade científica moderna.

Outra reflexão que contribui para a compreensão sobre o processo de formação de um pesquisador, é a de Bourdieu (1989), ao abordar o papel do orientador nesse processo. Refletindo sobre a construção do objeto nas pesquisas em Ciências Sociais, o autor destaca a relação entre a teoria 
(abstrata) e a prática e a importância do orientador no diálogo entre essas duas dimensões. Sobre a dimensão da prática, afirma que

[...] não há outra maneira de adquirir os princípios fundamentais de uma prática - e a prática científica não é exceção - que não seja da prática ao lado de uma espécie de guia ou de treinador, que protege e incute confiança, que dá exemplo e que corrige ao enunciar (BOURDIEU, 1989, p. 21).

Considerando o debate promovido por esses autores, Neves (2007) propõe que a formação de um pesquisador se baseie em critérios como:

(I) assimilar o modelo teórico a partir da literatura de tradição;

(II) exercitar a argumentação acadêmica, expressa numa literatura decorrente da literatura de tradição, porém mais específica;

(III) aprender no ambiente da produção científica e sob orientação de um pesquisador experimentado (NEVES, 2007, p. 14).

A partir da análise das entrevistas com os responsáveis pelos bolsistas nos museus de ciência da cidade do Rio de Janeiro, é possível afirmar que os alunos bolsistas PIBIC e PIBIC-EM (MAST e Museu Nacional) possuem uma formação que contempla esses três critérios. Eles se inserem em uma das linhas de pesquisa; têm contato com a literatura contida nos manuais; se envolvem em um projeto de pesquisa (original ou em andamento); apresentam seus resultados em eventos científicos e executam todas as suas atividades sob a supervisão de um orientador experimentado. Mais uma vez, é importante enfatizar que esses museus são divididos em diferentes setores que desenvolvem pesquisas em diferentes campos do conhecimento. No caso do Museu Nacional, como já explicado, há diferentes departamentos ligados às Ciências Naturais (como a Botânica, Geologia, Paleontologia, Zoologia), à Antropologia e à Educação (SAE), e no MAST, as coordenações de História da Ciência, Museologia, Documentação e Arquivo e Educação em Ciências. Os bolsistas PIBIC ligados a cada um desses setores são selecionados e desenvolvem suas atividades de pesquisa de acordo com os critérios e planos de seus respectivos orientadores.

Retomando a discussão de Ferreira (2010) sobre a necessidade de se considerar as especificidades da IC para alunos do ensino médio, e analisando as falas das entrevistadas do Museu Nacional, é possível afirmar que não há nenhuma diferença evidente no processo formativo dos bolsistas de ensino médio em relação aos de graduação. 
A seleção cabe ao Colégio Pedro II e as entrevistadas desconhecem os critérios. As atividades desenvolvidas no museu, no caso do recebimento de bolsas jovens talentos da FAPERJ, devem ser vinculadas à participação em uma pesquisa (com a apresentação dos trabalhos produzidos em jornadas promovidas pela FAPERJ e pela UFRJ). Nas falas, não é possível perceber se há uma avaliação conjunta entre as duas instituições (Museu Nacional/UFRJ e Colégio Pedro II), ou mesmo uma interlocução durante o processo formativo, como sugerem Matos e colaboradoras (2012).

Lembrando que os alunos de ensino médio participam do Programa de Iniciação Científica do Colégio Pedro II, que tem como objetivos: 1) possibilitar a vivência dos estudantes em diversas práticas de pesquisa científica em diferentes campos do conhecimento; (2) despertar o interesse pela organização e preservação do acervo institucional, e pelo desenvolvimento de atividades educativas e culturais; (3) permitir a vivência teórico prática de estudantes com a vida profissional e contribuir para uma escolha mais consciente de sua futura carreira, bem como preparar para o mundo do trabalho; (4) desenvolver no ensino médio novas experiências no processo de ensino-aprendizagem, contribuindo para a formação acadêmica dos alunos (BESSA, 2015).

É possível afirmar que mesmo que não haja especificidades no estágio pelo fato dos alunos cursarem o ensino médio, o estágio no Museu Nacional cumpre os objetivos do PIC Jr.

Os demais museus investigados a partir das entrevistas oferecem outros tipos de bolsa que não a de iniciação científica. O Espaço COPPE e o Museu da Química possuem apenas bolsistas de extensão e é possível afirmar que o estágio nesses museus não se configura como um processo de IC, pois as atividades dos bolsistas estão ligadas apenas à mediação das exposições e à execução das oficinas externas. Os processos de seleção e avaliação são determinados pelos editais para atividades de extensão da UFRJ63. Não há um envolvimento desses bolsistas em atividades de pesquisa e produção de conhecimento, o que parece ser uma

${ }^{63}$ A relação entre a extensão universitária e os processos formativos nos museus será discutida na próxima seção deste capítulo. 
dimensão crucial para a iniciação ao fazer científico. Severino (2012) afirma que a formação de novos pesquisadores deve ser sempre articulada à pesquisa, considerando-se que os espaços de formação devem ser espaços de fazer ciência e não apenas de transmiti-la. Pelo mesmo motivo - não engajamento em atividades de pesquisa - é possível considerar que os bolsistas de ensino médio do Pró-Cultural (Museu da Vida) não realizam uma iniciação científica e sim uma formação para atuarem como produtores culturais.

\subsection{1.}

\section{Iniciação científica com bolsas de outra natureza}

O referencial para a análise sobre o tipo de formação que os alunos bolsistas recebem no estágio em museus foi construído a partir de autores que investigam os sentidos da produção do conhecimento científico e da formação de pesquisadores, mas, como discutido no capítulo anterior, a ida ao campo revelou que nem todos os museus que sinalizaram a presença de bolsistas de IC nos questionários de fato possuem. Essa particularidade no caminhar desta pesquisa suscitou uma nova questão teórica ao longo do processo: é possível que um aluno faça iniciação científica mesmo que sua bolsa seja de outra natureza?

Ao avaliar o processo formativo dos bolsistas PROPOP do Museu da Vida, do Espaço Ciência Viva (bolsistas de extensão) e da SAE/Museu Nacional (bolsistas PDI), entendo que é possível afirmar que, independentemente do tipo da bolsa, os alunos realizam uma iniciação científica no campo da educação em museus.

Para o debate acerca desses três espaços (Museu da Vida, ECV e SAE/Museu Nacional) iniciarem a formação de pesquisadores no campo da educação em museus, mesmo no estágio de alunos de graduação que não são bolsistas de IC, é importante refletir primeiramente se a educação em museus se configura como um campo do conhecimento e o significado de campo do conhecimento em si.

Para Bourdieu (2004), a noção de campo de conhecimento deve englobar, mas ao mesmo tempo não se limitar, à produção textual e ao contexto social. A ligação entre esses dois polos é feita pelo "universo no 
qual estão inseridos os agentes e as instituições que a produzem, reproduzem ou difundem a arte, a literatura e a ciência. Esse universo é um mundo social como os outros, mas que obedece a leis sociais mais ou menos específicas" (BOURDIEU, 2004, p. 20)64.

Para o autor, uma das grandes questões acerca dos campos ou subcampos científicos é a questão da autonomia que eles usufruem. Quanto mais autônomo for um campo, maior será seu poder de refração às imposições externas. Ao contrário, a heteronomia de um campo se manifesta essencialmente quando problemas exteriores (em especial problemas políticos) se exprimem diretamente. Nesse sentido, a "politização"65 de uma disciplina não é um indício de grande autonomia.

Bourdieu defende que "todo campo científico é um campo de forças e um campo de lutas para conservar ou transformar esse campo de forças" (BOURDIEU, 2004, p. 22-23). Nesse sentido, a estrutura de um campo é, de um modo geral, determinada pela distribuição do capital científico ${ }^{66}$ num dado momento. Em outras palavras, os agentes (indivíduos ou instituições) caracterizados pelo volume de seu capital determinam a estrutura do campo. Mas, contrariamente, cada agente age sob a pressão da estrutura do espaço que se impõe a ele.

Os agentes fazem os fatos científicos e até mesmo fazem, em parte o campo científico, mas a partir de uma posição nesse campo - posição essa que não fizeram - e que contribui para definir suas possibilidades e suas impossibilidades (BOURDIEU, 2004, p. 25).

Deste modo, aquilo que se defronta no campo são construções sociais concorrentes, representações que se pretendem fundadas numa "realidade" dotada de todos os meios de impor seu veredito mediante o arsenal de métodos, instrumentos e técnicas de experimentação coletivamente acumulados e empregados, sob a imposição das disciplinas

\footnotetext{
64 Livro baseado em conferência proferida pelo autor em 1997.

${ }^{65}$ Aspas do autor.

66 O capital científico é uma espécie particular de capital simbólico (o qual é sempre fundado sobre atos de conhecimento e reconhecimento) que consiste no reconhecimento (ou no crédito) atribuído pelo conjunto de pares-concorrentes no interior do campo científico. O autor cita como exemplo o número de citações, prêmios, medalhas, mas é possível considerar também o número de publicações, a classificação dos periódicos onde essas publicações são feitas.
} 
e das censuras do campo e também pela virtude invisível da orquestração do habitus ${ }^{67}$. Portanto, a atividade científica depende sobretudo

"[...] do grau em que um campo científico está protegido contra intrusões (mediante, principalmente, o direito de entrada mais ou menos elevado que ele impõe aos recém-chegados e que depende do capital científico coletivamente acumulado) e do grau em que é capaz de impor suas sanções positivas e negativas." (BOURDIEU, 2004, p .34-35)

Embora não fale diretamente sobre a formação de novos pesquisadores, as reflexões do autor reforçam a ideia de que é na prática, inseridos nas instituições, convivendo com os diferentes autores e disputas, adquirindo habitus e capital científico, que um indivíduo se insere num determinado campo do conhecimento.

A noção de campo científico de Bourdieu em si não é suficiente para afirmar que a educação em museus se constitui como um campo do conhecimento autônomo. Para esta discussão, o diálogo com as reflexões de Martins (2011) parece ser um caminho profícuo, pois a autora procurou compreender as especificidades da educação em museus a partir da análise das atividades desenvolvidas em três instituições com tipologias distintas (um museu de Artes, um de Ciência e um de Antropologia).

Em um primeiro momento, Martins (2011) buscou entender as transformações que historicamente contribuíram para o crescimento da importância da educação nos museus e, em seguida, procurou desvendar os mecanismos de constituição e funcionamento dos processos educacionais existentes nas instituições.

Para a autora, são os educadores dos museus os responsáveis pela concepção e pela prática daquilo que é entendido como educação em museus. Esses profissionais não possuem uma formação específica, pois além dos cursos de graduação em Museologia serem escassos, a educação tende a ser apenas uma, entre várias disciplinas ministradas nesses cursos. Desta forma, os educadores que atuam em museus são oriundos de diferentes cursos de graduação, o que é corroborado pelas falas dos entrevistados dos museus em questão, que afirmam buscar não apenas alunos dos cursos de museologia para atuarem como bolsistas nas

\footnotetext{
${ }^{67} \mathrm{Na}$ definição do autor, habitus são disposições adquiridas, maneiras de ser permanente e duráveis que podem, em particular, levar os indivíduos a resistir, a opor-se às forças do campo.
} 
atividades educativas (Quadro 5). Como discutido no capítulo anterior, ao contrário, essas instituições tendem a priorizar grupos multidisciplinares de bolsistas com os alunos oriundos de cursos correlatos à tipologia ou atividades desenvolvidas por cada museu ${ }^{68}$ (lembrando que o tipo de curso de origem configura-se, muitas vezes, como um critério de seleção dos bolsistas).

Quadro 5: Cursos de origem dos bolsistas ligados às atividades educativas.

\begin{tabular}{|l|l|}
\hline \multicolumn{1}{|c|}{ Museu } & \multicolumn{1}{c|}{ Curso de origem } \\
\hline Espaço Ciência Viva & Artes \\
& Biomedicina \\
& Física \\
& Ciências Biológicas \\
& Engenharia Química \\
& Jornalismo \\
& Matemática \\
& Pedagogia \\
& Química \\
\hline Museu da Vida & Artes Cênicas \\
& Ciências Biológicas \\
& Dança \\
& Enfermagem \\
& Física \\
& História \\
& Museologia \\
& Pedagogia \\
& Produção Cultural \\
& Química \\
\hline & Ciências Biológicas \\
& Ciências Sociais \\
& Comunicação Social \\
& Geografia \\
& História \\
& História da Arte \\
& Pedagogia \\
& Terapia Ocupacional \\
\hline & \\
& \\
\hline
\end{tabular}

Fonte: Dados da Pesquisa

No ECV, ambos os entrevistados afirmaram que os bolsistas são, predominantemente, oriundos de cursos da área biomédica, em especial da biologia, porque os coordenadores do Espaço estão inseridos nessa área dentro da universidade.

Em relação ao Museu da Vida, Eric declara que a diversidade de cursos é provocada pela própria diversidade de espaços e práticas que o Museu possui.

\footnotetext{
68 Inclusive é importante destacar que nenhum dos profissionais que atuam como educadores e formadores dos bolsistas entrevistados para esta pesquisa possui formação na área de museologia (Quadro 2:).
} 
[o curso de origem dos bolsistas] É bastante eclético! Porque a nossa natureza enquanto museu de ciência é também uma natureza eclética. Eu costumo dizer que o Museu da Vida é um museu híbrido. Se você visitar só uma área temática do Museu, você vai ter certeza que ele é de um determinado perfil. Se você visitar só a outra área temática, você vai ter certeza também que ele é de outra área. Então se você for a uma visita ao Castelo Mourisco [...] você vai ter a nítida sensação que você está num museu de História. Se você for no Parque da Ciência, estará num "Science Center". Se você for ao Ciência em Cena, você vai ver uma peça de teatro [...]. É um museu muito híbrido, o que demanda um conjunto de profissionais formados, que trabalham e atuam com esses bolsistas também multidisciplinar. Temos pedagogo, historiador, físico, químico, biólogo, museólogo, ator. Há várias pessoas com várias formações diferentes. - Eric

O setor educativo (SAE) do Museu Nacional também possui um grupo de bolsistas multidisciplinar e chama atenção o fato de Anita lamentar a baixa procura por parte de alunos dos cursos de Pedagogia e de Letras Libras. Quando indagada sobre o porquê do interesse por alunos desses cursos em especial, percebe-se uma compreensão de que esses alunos trarão consigo conhecimentos de outras áreas para o desenvolvimento das atividades e práticas educativas do Museu.

Em relação à Pedagogia, entendemos que são futuros profissionais do campo de educação e que têm uma experiência, uma formação mais específica, no que diz respeito à educação de pessoas mais jovens, no caso crianças, e buscamos essa aproximação maior com a educação infantil dentro do Museu. Tanto em relação às crianças mesmo, quanto aos professores que trabalham diretamente com esse segmento. Então esse seria nosso interesse mais específico aos pedagogos em formação. Com relação a Letras Libras, está relacionado, também, a uma questão de acessibilidade, a aspectos comunicacionais. Entendemos e valorizamos a importância de ter profissionais que dominam a língua brasileira de sinais, que poderiam fazer visitas com a comunidade surda, visitas educativas ou atividades educativas com a comunidade surda em sua primeira língua. Anita

A necessidade de se formar uma equipe multidisciplinar, tanto de profissionais quanto de bolsistas, está relacionada ao fato da educação em museus demandar saberes de áreas distintas, que não se limitam aos saberes do campo da museologia ou da educação. No caso dos museus de ciência, há também os saberes das ciências de origem, sobre o ensino de ciências e, como discutido no capítulo 4, os saberes que são próprios dos museus.

Gomes e Cazelli (2016) ressaltam que o mediador idealmente precisa dominar um saber disciplinar. Para as autoras, o fato do mediador conhecer tais conteúdos é uma condição essencial para que não seja um mero 
transmissor de informações, mas que conduza um diálogo com o público. Entretanto, Gomes e Cazelli (2016) também destacam que, se a proposta do museu é provocar o interesse sobre suas temáticas através de contextualizações, é imprescindível que esse profissional detenha as ferramentas que propiciem uma boa comunicação com os diferentes tipos de público. Ou seja, a prática de um educador em um museu demanda a mobilização de conhecimentos.

Portanto, a formação dos profissionais de educação em museus não ocorre em um curso de graduação específico, mas na prática, por meio do estágio nos setores educativos e da participação em seminários e encontros na área (MARTINS, 2011). A reflexão de que a formação desses profissionais ocorre na prática também é feita por Queiroz (2002), que afirma que esses educadores se formam por meio da experiência nos próprios museus, onde tem se dado a construção dos saberes necessários a esta função.

Muitos desses profissionais, em busca por uma "educação formal", se inserem em programas de pós-graduação. Martins (2011) afirma que para os educadores dos museus por ela investigados,

[...] a oportunidade de crescimento profissional no campo está associada a um desenvolvimento acadêmico que longe de ser um "complemento" à formação, é a base para a reflexão sobre a prática educacional desenvolvida (MARTINS, 2011, p. 310).

Ainda em relação à reflexão da educação em museus como campo de conhecimento, sua inserção na pós-graduação se configura como aspecto basilar. Se pensarmos que, como discutido no capítulo 3, a pósgraduação é um espaço que assume protagonismo na produção de conhecimento no país, é igualmente importante considerar qual o espaço da pesquisa em educação em museus na pós-graduação brasileira. Atualmente há dois programas ligados à Museologia inseridos na área de Ciências Sociais Aplicadas da Capes, subárea de Comunicação, Ciências da Informação e Museologia.

O Programa de Pós-Graduação em Museologia e Patrimônio, parceria entre a Universidade Federal do Estado do Rio de Janeiro (Unirio) e o MAST, foi fundado em 2006 e atualmente conta com cursos em nível de mestrado e doutorado e o Programa de Pós-Graduação Interunidades da 
Universidade de São Paulo (sob a responsabilidade dos Museus Estatutários da USP'99), criado em 2012, apenas com curso de mestrado. Nesses programas são desenvolvidas pesquisas na área de educação em museus, mas a educação não é o foco principal dos cursos, que possuem as seguintes linhas de pesquisas: "Museus e Museologia" e "Museologia, Patrimônio de Desenvolvimento Sustentável" no caso do PPGP-MUS Unirio/MAST e "História dos processos museológicos, coleções e acervos"; "Teoria e Método da Gestão Patrimonial e dos Processos Museológicos" e "Salvaguarda do patrimônio cultural e coleções museológicas", no PPGMus USP.

Apesar de não existir programas stricto sensu ${ }^{70}$ específicos sobre a educação em museus Seibel-Machado (2009), em sua tese, mostra que houve um crescimento do número de pesquisas na área do final da década de 1980 até a década de 2000. Martins (2011) também apresenta dados que indicam a existência de linhas de pesquisa relacionadas à educação em museus em programas de diferentes áreas de conhecimento como as de educação e ensino de ciências.

Embora se verifique, então, um crescimento nas linhas de pesquisa sobre essa temática, tanto Seibel-Machado (2009) quanto Martins (2011) reafirmam que grande parte do conhecimento sobre a educação em museu é produzida a partir da prática e por profissionais da área.

Após essa reflexão, é importante retornar à pergunta: a educação em museus se constitui como um campo do conhecimento? Por um lado, levando em conta as definições de Bourdieu (2004) sobre a constituição de um campo, é possível supor que sim, na medida em que os conhecimentos da área são produzidos principalmente por agentes inseridos nos contextos museais, e que tem sua produção avaliada por pares da mesma área. Por

69 Os Museu de Arqueologia e Etnologia; Museu de Arte Contemporânea; Museu de Zoologia e o Museu Paulista são chamados Museus Estatutários da USP, pois o estatuto vigente na universidade define estas instituições como órgãos integradores juntamente com os núcleos de apoio à pesquisa. Diferente das unidades de ensino, os órgãos integradores não oferecem diploma de graduação, mas são unidades orçamentarias com autonomia acadêmica (BRANDÃO e COSTA, 2007).

70 Em 2014 foi criada a Pós-Graduação Lato Sensu em Educação Museal. Este curso de especialização é uma cooperação técnica entre Museu Castro Maia, Museu da República (pertencentes ao IBRAM) e Instituto Superior de Educação do Rio de Janeiro (ISERJ), via Fundação de Apoio à Escola Técnica (FAETEC). Mais informações em <http://www.museus.gov.br/tag/pos-graduacao/>. Acesso em: 20 jan. 2018. 
outro lado, a falta de programas de pós-graduação e o número reduzido de linhas de pesquisa diretamente relacionadas faz com que esse campo tenha um menor capital científico e seja menos autônomo.

Os dados obtidos no questionário do GEPEMCI ajudam nessa discussão sobre a autonomia do campo, especificamente ao se analisar os dados relativos às áreas do conhecimento em que os setores educativos em que os museus da cidade do Rio de Janeiro realizam pesquisa. Dos 44 museus da cidade do Rio de Janeiro que afirmaram possuir setor educativo, 20 declararam que este setor realiza pesquisa. Desses 20 , seis afirmaram que realizam pesquisas relacionadas à educação em museus e os demais realizam pesquisas sobre temáticas ligadas à tipologia da instituição. Importante ressaltar que desses seis museus, 3 fazem parte do grupo de museus de ciência investigados nesta pesquisa a partir das entrevistas: MAST, Museu Nacional, Museu da Vida. Os demais museus que informaram fazer pesquisas relacionadas à educação em museus foram: o Centro Cultural Banco do Brasil, o Museu do Folclore e o Museu da Geodiversidade (UFRJ). Desta forma, dentro do universo de museus estudados, são poucos os que afirmaram realizar pesquisa no campo.

Aqui cabe também destacar que dos seis museus identificados na pesquisa do GEPEMCI, quatro são museus de ciência e pertencem à UFRJ, e são ou estão vinculados a um instituto de pesquisa. O fato do museu estar ligado a uma universidade parece favorecer a presença de alunos bolsistas. Dos 41 museus de ciências que responderam no questionário possuir bolsistas, 28 são museus ligados a universidades.

Durante o levantamento bibliográfico sobre educação em museus e pedagogia museal realizado para o desenvolvimento desta pesquisa, a maior parte dos artigos brasileiros encontrados foi produzido por pesquisadores vinculados aos museus de ciência. Estas instituições têm em sua história uma forte ligação com as questões de cunho educacional (VALENTE, 1995), o que faz com que sejam protagonistas no desenvolvimento de pesquisas na área de educação em museus e que busquem um aprofundamento teórico que sirva de base para a construção de suas práticas educativas (GOMES e CAZELLI, 2016). Vale ressaltar que, como já citado, essa tipologia de museu possui uma associação 
própria no país: a Associação Brasileira de Centros e Museus de Ciência (ABCMC). A ABCMC foi criada em 1999 com o objetivo de compartilhar experiências, informações e recursos entre esses museus. Além disso, a Associação pretende "identificar, fortalecer e difundir áreas e atividades de cooperação, apoiando programas de divulgação científica e articulando uma Política Nacional de Popularização da Ciência". ${ }^{71}$ A ABCMC já realizou dois encontros nacionais para a troca de experiências e práticas entre os membros das instituições filiadas e pesquisadores interessados.

Se partimos do pressuposto de Martins (2011) e Queiroz (2002) de que o conhecimento do campo é produzido pelos profissionais dos próprios museus, é possível inferir então que esse é um campo ainda em construção e com pouca autonomia, uma vez que a produção do conhecimento parece estar fortemente ligada ao fato das instituições estudadas estarem vinculadas à universidade e centros de pesquisa, que reconhecidamente são locais destinados à produção de conhecimento. E que mesmo quando um museu pertence à universidade, não necessariamente está realizando pesquisa no campo, sendo visto como um espaço destinado apenas à extensão.

Voltando à questão sobre se três dos espaços investigados - Museu da Vida, Espaço Ciência Viva e da SAE/Museu Nacional - realizam IC com seus estagiários no campo da educação em museus, é possível então afirmar que sim, pois, independente da natureza da bolsa, essas instituições iniciam alunos nesse campo, considerando os seguintes pressupostos:

(I) A educação em museus é um campo do conhecimento novo, emergente e ainda em processo de acúmulo de capital científico por parte de seus membros e instituições.

(II) A formação dos pesquisadores nesse campo se dá principalmente associada à prática como educadores nos espaços museais.

(III) Para que a formação de pesquisadores se configure com tal, é necessário que haja a participação do aluno em atividades de pesquisa.

\footnotetext{
${ }^{71}$ Disponível em < http://www.abcmc.org.br>. Acesso em: 02 abr. 2017.
} 
Em relação especificamente ao pressuposto III, é possível perceber, na fala dos entrevistados, que, mesmo quando os alunos não são bolsistas de IC, há uma intencionalidade que eles se envolvam nas atividades de pesquisa que essas instituições desenvolvem nas linhas de educação em museus e divulgação e popularização da ciência, mas que a natureza da bolsa algumas vezes traz limitações. No caso dos bolsistas da SAE do Museu Nacional, Anita aponta que o fato da bolsa não ser uma bolsa de IC dificulta o envolvimento desse grupo na pesquisa, mas que esse é um desejo da equipe.

[...] existe uma dificuldade por parte deles [bolsistas], não sei se é falta de interesse ou uma dificuldade mesmo em produzir um trabalho mais acadêmico, ou ter esse olhar para o trabalho que eles realizam, de pesquisa científica a partir da própria prática para pensar a prática, ou de olhar sobre a sua prática. Então fazemos reuniões de planejamento, investir nisso, na leitura de textos. Para que eles possam perceber como os colegas de outras instituições vêm produzindo academicamente trabalhos no campo da educação museal. E para que eles percebam, e busquem desenvolver trabalhos nesse sentido. Eu acho que é nesse ponto que precisamos avançar mais. - Anita

No Museu da Vida, todas as atividades dos bolsistas são interligadas: formação, mediação e avaliação. Há momentos com os alunos em que são discutidas as questões teóricas ligadas à educação em museus e à divulgação e popularização da ciência (no início e durante o estágio) e os bolsistas são estimulados a avaliar e produzir conhecimento sobre a própria prática, e, como discutido no capítulo anterior, incentivados a apresentar os resultados em eventos científicos. O movimento da equipe do museu em criar um programa próprio de Iniciação da Difusão e Popularização da Ciência parece estar relacionado à necessidade de formar pessoas dentro dos campos da difusão da ciência e da educação em museus.

No ECV, mesmo os alunos sendo bolsistas de extensão, existe a intenção de que todos se envolvam nas atividades de pesquisa que, assim como no Museu da Vida, estão relacionadas às temáticas da educação em museus e à divulgação e popularização da ciência. No ECV, especificamente, a pesquisa está relacionada ao desenvolvimento e avaliação dos módulos interativos.

Essa galera que a gente orienta têm de fazer uma pesquisa, que normalmente é o desenvolvimento de um módulo interativo ou avaliação de 
algum módulo interativo e, ao mesmo tempo, ele atua também na mediação das crianças das escolas. - Fernando

Entretanto, assim como acontece na SAE do Museu Nacional, o envolvimento do bolsista na pesquisa, embora seja um desejo da instituição, depende do interesse do aluno, uma vez que não é obrigatório.

Os nossos alunos de extensão desenvolvem pesquisa também apesar de serem bolsistas de extensão, não são todos, depende do projeto e depende do interesse do aluno - Ludmila

A iniciação científica como processo de formação de pesquisadores, independente da modalidade de bolsa recebida pelo aluno, demanda que o aluno se envolva necessariamente em atividades de pesquisa. Esse parece ser o marco que de fato caracteriza esse processo. Entretanto, as bolsas de extensão são mais frequentes nos museus estudados. Como o objetivo desta pesquisa passa pela compreensão de como é e quais são os sentidos formativos do estágio nos museus, a reflexão sobre a dimensão formativa da extensão universitária será feita na seção a seguir.

\section{3.}

\section{A extensão universitária como espaço de formação}

Como já sinalizado anteriormente, a dimensão formativa da extensão não era objeto inicial de investigação desta pesquisa. Entretanto, três dos museus investigados (Espaço Ciência Viva, Espaço COPPE e o Museu da Química) possuem atualmente bolsistas de extensão. É importante lembrar que o Espaço COPPE e o Museu da Química são museus integrados à UFRJ e o Espaço Ciência Viva é uma ONG dirigida por um conselho composto por professores dessa mesma universidade ${ }^{72}$. Destaca-se também, como já explicitado no capítulo anterior, que a bolsa de extensão foi a modalidade de bolsa mais citada no questionário enviado aos demais museus e centro de ciências do país (mencionada por 24 das 41 instituições que afirmaram possuir alunos bolsistas).

A presença dos bolsistas de extensão nos museus e a análise dos processos formativos nessas instituições suscitaram algumas questões: qual é o papel formativo da extensão para os alunos? Há aproximações ou

\footnotetext{
72 São esses professores que solicitam as bolsas para os alunos a partir de editais para a pesquisa e extensão universitária.
} 
diferenças entre a formação na IC e na extensão? Existe diálogo entre a formação em museus e a extensão universitária?

Para responder a essas indagações, é necessário entender a extensão como dimensão formativa. A extensão universitária é definida no Plano Nacional de Extensão de 1999 como o

[...] processo educativo, cultural e científico que articula o Ensino e a Pesquisa de forma indissociável e viabiliza a relação transformadora entre Universidade e Sociedade. A Extensão é uma via de mão-dupla, com trânsito assegurado à comunidade acadêmica, que encontrará, na sociedade, a oportunidade de elaboração da praxis de um conhecimento acadêmico. No retorno à Universidade, docentes e discentes trarão um aprendizado que, submetido à reflexão teórica, será acrescido àquele conhecimento. Esse fluxo, que estabelece a troca de saberes sistematizados, acadêmico e popular, terá como consequências a produção do conhecimento resultante do confronto com a realidade brasileira e regional, a democratização do conhecimento acadêmico e a participação efetiva da comunidade na atuação da Universidade. Além de instrumentalizadora deste processo dialético de teoria/prática, a Extensão é um trabalho interdisciplinar que favorece a visão integrada do social (BRASIL. MEC. SeSu. FOPROEX, 1999, p. 1).

A extensão universitária surge na Europa (século XIX) como uma resposta às demandas da classe trabalhadora pós-Revolução Industrial. Neste contexto, as universidades respondem a necessidade dos Estados de soluções apaziguadoras para os movimentos da classe operária. Já nos EUA (início do século XX), as universidades se aproximam do setor empresarial cumprindo o papel de desenvolver tecnologias que atendam às demandas deste setor. Desta forma, nos países centrais, a extensão universitária tem suas origens ligadas a interesses do modelo de desenvolvimento capitalista (PAULA, 2013).

Na América Latina, a extensão começou a ser praticada a partir de outros parâmetros e motivações e foi fortemente influenciada pelos movimentos sociais. A luta pela reforma universitária, que ocorreu nas primeiras décadas do século XX, em países como o México ${ }^{73}$, fez parte de uma luta mais geral, com grande participação do movimento estudantil que, entre outros aspectos, questionava o distanciamento das universidades

${ }^{73}$ É importante destacar que, ao contrário do Brasil, em que as universidades foram criadas apenas na primeira metade do século XX, no restante da América do Sul as universidades foram criadas ainda no período colonial (as primeiras já no século XVI) e eram controladas por ordens religiosas. 
dos grandes problemas sociais, econômicos, políticos e culturais das nações latino-americanas (PAULA, 2013)

No Brasil, a história da extensão universitária teve um caminho um pouco diferente do resto da América Latina, inclusive porque, como discutido no capítulo 2 , a criação das universidades ocorreu apenas na década de 1920-30. A extensão passou a ser prevista em lei a partir do decreto $\mathrm{n}^{\circ} 19.851$ de $1931^{74}$ (BRASIL. MEC, 1931) durante o ministério de Francisco Campos. O decreto, em seu artigo no 109, indicava que a extensão universitária se destinava à difusão de conhecimentos filosóficos, artísticos, literários e científico em benefício do aperfeiçoamento individual e coletivo. E que deveria ser feita por meio de cursos dentro e fora das universidades, conferências, propagandas ou demonstrações práticas ( $\S$ $\left.1^{\circ}\right)$.

$\mathrm{Na}$ análise de Rothen (2008), a Reforma Universitária de Francisco Campos se aproximava de um modelo norte-americano, ao apontar para a necessidade da universidade estabelecer laços de solidariedade com a sociedade, e entendendo que essa aproximação seria feita, então, através da extensão. Mas, segundo o autor, cabe lembrar que a indissociabilidade entre ensino, pesquisa e extensão não estavam presentes neste documento, nem como uma aspiração, o que muito provavelmente se deve ao fato de Campos compreender que a função pragmática da universidade era a formação profissional, como também discutido no capítulo 2.

Embora inicialmente incipiente, a extensão passou a ter considerável papel na luta por transformações sociais e reformas estruturais ocorridas entre 1950-64, sendo pautada, por exemplo, nos congressos da União Nacional dos Estudantes (UNE). Mas foi no Serviço de Extensão da Universidade de Recife, dirigido por Paulo Freire ${ }^{75}$, que foi feita a integração da universidade e da extensão universitária às grandes questões nacionais, ampliando o debate que já vinha sendo feito pelos estudantes em luta por uma reforma universitária (PAULA, 2013).

\footnotetext{
74 Decreto também conhecido como "Estatuto das Universidades Brasileiras" e que integrou o conjunto de reformas implantadas pelo então ministro da educação e da saúde pública, Francisco Campos, durante o governo de Getúlio Vargas.

${ }_{75}$ Paulo Freire foi importante educador e pedagogo brasileiro, autor de vários livros que serviram de base para a pedagogia crítica e educação popular no Brasil.
} 
Em seu livro "Extensão ou Comunicação?"76, Freire (2013) apresenta reflexões sobre o papel da extensão que seriam usadas como base para o debate acadêmico e político sobre o tema. A partir de estudos com agrônomos e agricultores chilenos, o autor faz uma crítica ao termo extensão, por sua relação significativa com a ideia de transmissão, entrega, doação messianismo, mecanicismo, invasão cultural, manipulação etc. Para Freire (2013), esses termos envolvem ações que, transformando o homem (agricultor) em quase "coisa", o negam como um ser de transformação do mundo.

$\mathrm{Na}$ crítica apresentada pelo autor, o agrônomo se veria como detentor de um conhecimento técnico científico e sua ação extensionista ignoraria todo o conhecimento dos agricultores sobre suas regiões e práticas agrícolas. Dentro dessa ótica, a ação envolveria "a necessidade que sentem aqueles que a fazem, de ir até "outra parte do mundo", considerada inferior, para, à sua maneira, "normalizá-la". Para fazê-la mais ou menos semelhante a seu mundo" (FREIRE, 2013, p. 13). Embora tenha estudado especificamente práticas extensionistas de agrônomos para com agricultores, o autor entendia que essa visão de extensão, em que o conhecimento deveria ser simplesmente transmitido, poderia ser generalizada para qualquer outro setor que realizasse essas práticas.

A grande contribuição de Freire para o campo foi, portanto, a mudança de paradigma sobre a extensão, como um processo onde a universidade seria a detentora de um conhecimento científico que deveria ser levado à população, que está fora dela (população essa que não deteria nenhum conhecimento relevante), para um paradigma de extensão dialógico, em que o conhecimento é produzido justamente no diálogo entre quem possui um conhecimento técnico e quem possui outras formas de conhecimento, de maneira que esses saberes não fossem hierarquizados. Para o autor:

Educar e educar-se, na prática da liberdade, não é estender algo desde a "sede do saber" até a "sede da ignorância" para "salvar", com este saber, os que habitam nesta. [...] Ao contrário, educar e educar-se, na prática da liberdade, é tarefa daqueles que sabem que pouco sabem - por isso sabem que sabem algo e podem assim chegar a saber mais - em diálogo com aqueles que, quase sempre, pensam que nada sabem, para que estes,

${ }^{76}$ Livro publicado em 1969, sob o título de Extención o Comunicación?, pelo Instituto de Capacitación e Investigación en Reforma Agrária, em Santiago de Chile. 
transformando seu pensar que nada sabem em saber que pouco sabem, possam igualmente saber mais. (FREIRE, 2013, p. 15).

Com o golpe militar de 1964, o debate oficial sobre o tema foi interrompido. Na Reforma Universitária de 1968, a extensão é tornada obrigatória em todos os estabelecimentos de ensino superior e nas universidades, mantendo o modelo já existente de cursos e serviços estendidos à comunidade (BRASIL, 2007).

Entretanto, a reflexão sobre um novo modelo de extensão continuou através movimentos sociais urbanos e rurais, voltando ao debate político oficial no período de redemocratização na década de 1980 (PAULA, 2013). Em 1987, é criado Fórum de Pró-reitores de Extensão da Universidades Públicas (FOPROEX) que passa a expressar um novo conceito de extensão baseado nos princípios da indissociabilidade e ação transformadora, com interação social e interdisciplinaridade. Logo depois, em 1988, é aprovado na Constituição o princípio da indissociabilidade ensino - pesquisa - extensão ${ }^{77}$ (BRASIL. MEC. SeSu. FOPROEX, 2007). Neste contexto, a visão sobre o papel da extensão universitária supera uma visão tradicional de simples difusão e prestação de serviços para uma concepção de universidade em que a produção do conhecimento, via extensão, seria feita a partir da troca de saberes sistematizados, acadêmicos e populares.

Embora a Constituição de 1988 traga o conceito de indissociabilidade entre essas três funções da universidade, conhecida como "tripé universitário", Moita e Andrade (2009) ressaltam o quanto a articulação entre essas três dimensões pode se limitar a relações duais. Os autores citam como exemplos uma articulação entre ensino e extensão que aponte para uma formação que se preocupe com os problemas da sociedade, mas que não envolva a pesquisa e, consequentemente, a produção de conhecimento científico. A articulação entre ensino e pesquisa, que pode gerar novas tecnologias, mas que não necessariamente leve a uma compreensão ético-político-social, e, por fim, a articulação entre pesquisa e extensão (menos frequente segundo os autores), sem a presença do

\footnotetext{
77 Artigo ํㅡㄴ 207 da Constituição Federal.
} 
ensino, perde a dimensão formativa que é o sentido da universidade (MOITA e ANDRADE, 2009).

Os autores reconhecem a importância dessas relações, mesmo que de forma dual, mas defendem que a articulação das três dimensões ensinopesquisa-extensão evita reducionismos na prática universitária, onde ora se enfatiza a produção de um novo saber, ora se transmite conhecimentos para a formação profissional, ou ora se pensa sobre a intervenção nos processos sociais.

Considerando essa dimensão dialógica com a sociedade, Paula (2013) entende que as universidades tenham o papel de abrigar órgãos e espaços que possam desenvolver atividades que permitam a interligação entre a cultura científica e a cultura das humanidades. Assim, museus, espaços expositivos, teatros, galerias, bibliotecas, dentre outros, seriam veículos de mediação entre

os produtores de conhecimentos e bens simbólicos e os destinatários dessas ações, sejam eles estudantes, sejam eles os vários sujeitos externos à universidade, igualmente legítimos destinatários da ação universitária (PAULA, 2013, p. 21-22).

Nesse sentido, os museus ligados às universidades têm esse papel extensionista, na medida em que promoverão o diálogo entre o conhecimento científico produzido nessas instituições e o conhecimento trazido pelo público visitante. Neste ponto, cabe perguntar: a formação dos alunos bolsista nos museus investigados considera a indissociabilidade entre pesquisa-ensino e extensão?

No Espaço COPPE, como dito no capítulo anterior, todos os bolsistas são de extensão. De acordo com Ruth, o Espaço passou a ter esses bolsistas a partir do momento em que se tornou aberto à visitação do público (2002). A tarefa desses bolsistas é mediar a exposição permanente e participar da elaboração de oficinas externas que são realizadas em reuniões da Sociedade Brasileira para o Progresso da Ciência (SBPC) e na Semana Nacional de Ciência e Tecnologia. Pelas atribuições dos alunos bolsistas, nota-se que a visão de extensão se aproxima de uma visão tradicional da década de 1930, onde as atividades extensionistas teriam como objetivo levar o conhecimento produzido na universidade para o público, no caso, através da visita à exposição e das oficinas externas em 
eventos. É interessante lembrar que a própria criação do Espaço tem esse viés, uma vez que foi idealizado para que fossem divulgadas as pesquisas realizadas pela COPPE.

O trabalho dos alunos não tem relação com a pesquisa, logo, como discutido por Moita e Andrade (2009), envolve a relação dual ensino e extensão. É interessante destacar a fala de Ruth, de que as políticas recentes para a extensão serão benéficas para as atividades do Espaço, pois, além de contribuírem para o reconhecimento dos museus e centros culturais da universidade como espaços para o desenvolvimento da extensão, também irão contribuir para o aumento do número de pessoas envolvidas nesses espaços:

[...] agora tem uma lei que os alunos precisam fazer uma carga horária de extensão, o que eu acho que vai ajudar bastante, pelo menos os museus e centros culturais que são da universidade. Acho que vai ser legal, vai ajudar a incentivar, inclusive aos professores que também têm a obrigação de fazer uma carga horária de extensão. Então, eu acho que isso [a obrigatoriedade da carga horária de extensão] vai ajudar muito [...] porque ainda tem muito o que fazer e seria bom ter mais gente envolvida. - Ruth

O Museu da Química foi cadastrado como projeto de extensão na Próreitoria de extensão da UFRJ desde o ano de sua criação (2001). Esse cadastro permitiu que o museu se enquadrasse como apto a solicitar bolsas de extensão e de apoio estudantil. O Museu foi o primeiro projeto de extensão do Instituto de Química da UFRJ. Segundo Antônio, a demanda por bolsas de extensão começou a aumentar a partir de 2005, "porque a extensão embora sempre fosse reconhecida como parte do tripé [universitário], ela nunca era levada muito a sério...". O entrevistado relata que o Instituto foi criado voltado para a formação no nível de pós-graduação e que, com seu crescimento, mais tarde incorporou a graduação. Mas "a extensão é uma cultura muito recente, tem mais ou menos 15 anos" (se referindo ao Instituto e a própria UFRJ em si).

Em relação às atividades desenvolvidas pelos bolsistas de extensão, a partir da fala de Antônio, é possível perceber uma visão de extensão semelhante à encontrada no Espaço COPPE: a de difundir o conhecimento produzido na universidade.

Eles têm uma tarefa, dentro do âmbito da extensão, que é um dos pilares [da universidade], que é levar a mensagem que pretendemos, juntamente com a divulgação da universidade junto a sociedade, suas realizações, suas 
competências, seu passado, ela tem uma memória muito rica, a Universidade Brasileira, mais do que aparenta, apesar hoje da situação. Antônio

Entretanto, quando fala sobre as possibilidades formativas das atividades de extensão para os alunos bolsistas, a visão de Antônio sobre a extensão se aproxima mais do indicado pelo Plano Nacional de Extensão, uma vez que considera o diálogo com a sociedade e a interdisciplinaridade nesses processos formativos.

Para eles [alunos bolsistas] é uma oportunidade de ter o contato com o mundo da universidade fora um pouco da área mais técnica, mais Química, é uma Química ligada à História, um pouco à Antropologia, Relações Internacionais, Sociologia, Arquivologia, Museologia, curso que não temos [UFRJ], Biblioteconomia, curso recente aqui... História. Então ele [aluno] sai do lugar comum e permeia outras áreas do conhecimento, mostrando que o conhecimento pode ser classicamente dividido de Astronomia à Zoologia, mas que, na verdade, sempre há um grau de inter-relação e essa capacidade de inter-relacionar áreas, conceitos e visões é muito importante para formar uma mentalidade mais aberta do aluno, para não ficar aquela coisa fechada, uma coisa assim estanque, tudo é separado, o que é a mais pura inverdade. Então o principal ganho para eles é essa capacidade de ser um cidadão mais aberto, perceber que tudo se relaciona, que tudo tem uma consequência, que a Ciência não é fechada em si, ela tem que transpirar com outras áreas e dela própria, então isso é que faz enriquecer a experiência de uma vida, e que, de quebra, quando o lado mais químico, digamos, é evocado, ele reforça seu conhecimento e sua formação. Então é um projeto completo que realmente eleva o nível de formação intelectual e pessoal de um aluno bolsista. E você ainda leva a universidade para fora, ou traz o que é de fora para dentro, então Universidade ela realmente sai do seu lugar comum. E isso é realmente cumprir a principal missão a que se coloca, ao que se propõe um projeto de extensão. - Antônio

O Espaço Ciência Viva atualmente funciona através de projetos de extensão coordenados por professores da UFRJ e elaborados especificamente para serem desenvolvidos no museu. Pela fala dos entrevistados, não há uma diferença entre a formação e as atividades desenvolvidas pelos alunos bolsistas de IC ou extensão. Nessa perspectiva, é uma formação que contempla as três dimensões do tripé universitário: ensino, pesquisa e extensão e nela há uma preocupação com a interdisciplinaridade e com o desenvolvimento de atividades que dialoguem com a sociedade. De acordo com Ludmila, "o objetivo [dos projetos e do museu] é fazer a integração universidade, museu, sociedade". Para Fernando, o Ciência Viva "é um programa de extensão em que se estimula o licenciando ou o bacharel a entender essa ação social de sair 
das quatro paredes, de ir para uma praça pública, de ir para uma escola, de organizar um evento".

Olhando esses três museus, é possivel notar que o Espaço COPPE tem uma visão mais tradicional de extensão e de museu como espaço de difusão dos conhecimentos produzidos pela universidade. O Museu da Química também parece ter essa visão tradicional, mas considera que o envolvimento dos estudantes de graduação nessas atividades levará a uma formação mais interdisciplinar e em diálogo com a sociedade, o que se aproxima mais da visão de extensão freiriana presente no Plano Nacional de Extensão. Em ambos os museus, a extensão mantém uma relação dual entre ensino e extensão. Já o Espaço Ciência Viva parece ser o que mais se aproxima de uma extensão dialógica com a sociedade, considerando a interdisciplinaridade nessa formação que também inclui as três dimensões do tripé universitário: ensino, pesquisa e extensão.

Aqui cabe questionar mais uma vez se é o tipo de bolsa que define a natureza do trabalho e da formação do estudante. É provável que esses espaços solicitem as bolsas disponíveis e possíveis de serem solicitadas pela sua equipe ${ }^{78}$ de trabalho e que as atividades desempenhadas e a formação desses alunos, portanto, não sejam diferentes de acordo com o tipo de bolsa que ele recebe.

Também cabe problematizar, como já abordado no capítulo 4, que muitos museus carecem de profissionais em suas equipes, e o alunos bolsistas podem acabar assumindo o papel de um profissional que atua de forma temporária e sem vínculos empregatícios, como discutido por Carvalho (2016), Caffagni (2010) e Alencar (2008).

A fala de alguns entrevistados reforça a ideia de que sem a presença dos bolsistas não seria possível realizar boa parte das ações educativas. $\mathrm{Na}$ fala de Fernando (ECV), percebe-se que o próprio funcionamento da instituição depende da presença dos bolsistas.

Os bolsistas são vitais, porque sem eles nós não existimos. Nossa instituição não tem recursos para pagar salários para todos, somos uma ONG sem fins lucrativos. Todos que estão na diretoria realizam praticamente trabalho

78 Para que sejam solicitadas bolsas de iniciação científica (PIBIC), a equipe do museu precisa ter professores do magistério superior ou técnicos-administrativos doutores. As bolsas de extensão podem ser solicitadas por docentes ou técnicos-administrativos sem pré-requisito de titulação. 
voluntário, quando não investe dinheiro em alguma atividade (risos). Só que também não temos condições de bancar uma equipe de 20, 30 e mediadores para o estarem aqui cotidianamente. Então, na realidade, eles [bolsistas] são absolutamente vitais, eles são todo nosso gás, eles são todos nossa energia. - Fernando

Anita (Museu Nacional) também destaca a importância da presença dos bolsistas para compor a equipe e desenvolver atividades educativas com um maior alcance de público, mas destaca a necessidade de que haja uma reflexão sobre a proporção entre trabalhadores servidores públicos e o número de bolsistas.

Nós não participaríamos de eventos fora do museu nos finais de semana, se não tivéssemos esses bolsistas. Então do ponto de vista, tanto qualitativo quanto quantitativo, o grande número de ações e de número de cidadãos que são alcançados pelas ações, a presença de bolsistas é fundamental. [...] a gente vem aumentando inclusive o número de vagas [para bolsistas], mas temos que muitas vezes pisar no freio e pensar nessa relação servidores, educadores, e número de bolsistas. - Anita

$\mathrm{Na}$ fala de César (MAST), percebe-se que essa necessidade do bolsista como mão de obra para que as ações sejam desenvolvidas é maior na coordenação de educação do que nas demais coordenações.

Nós não conseguiríamos realizar a maioria das nossas ações sem bolsistas. Não temos pernas, não tem braços para... Porque ao contrário das outras coordenações, os bolsistas da coordenação de educação, todos eles, além de estarem ligados a uma pesquisa, porque a bolsa está ligada pesquisa, eles estão ligados alguma ação educativa, alguma ação de popularização e divulgação. Todos eles então, além do trabalho de iniciação, além da pesquisa, eles vêm final de semana fazer alguma atividade. [...] na coordenação da educação sem bolsistas a gente teria muito pouco a oferecer nessa área. Eles é que fazem o grande trabalho. - César

O fato das instituições demandarem a presença de bolsistas para suprir uma necessidade de mão de obra nas equipes dos setores educativos não exclui o fato de que haja uma preocupação com a formação desse aluno durante o estágio. Muito pelo contrário, como discutido até aqui, há uma preocupação da maioria das equipes com os sentidos formativos.

Se na seção anterior foi discutido que o envolvimento em atividades de pesquisa parece ser um marco para a formação de um pesquisador e, portanto, para que haja um processo de iniciação científica, a visão atual de extensão universitária congrega os eixos ensino, pesquisa e a própria extensão. Portanto, a IC pode ocorrer com alunos engajados em projetos de extensão, desde que haja o envolvimento do aluno em processos de 
produção do conhecimento. O ECV, por exemplo, é um espaço em que, independente da natureza da bolsa, aparentemente todos os bolsistas se vinculam em atividades de pesquisa e extensão.

Uma diferença percebida entre esses processos formativos foi que, na IC, parece caber mais ao pesquisador-orientador as decisões sobre a seleção, atividades desenvolvidas e mecanismos de avaliação dos alunos do que na extensão, onde esses critérios parecem ser definidos pelos editais de bolsas das universidades. Talvez essa maior autonomia para as decisões do orientador na IC tenha a ver com a própria história dessas instâncias formativas, sendo a pesquisa presente nas universidades brasileiras desde a sua criação e a extensão bem mais recente.

Essa diferença no controle dos critérios também pode ser consequência da pouca reflexão da IC como processo pedagógico. Massi e Queiroz (2015) consideram que mesmo com o crescimento do número de bolsas de IC ao longo da história do CNPq e da pós-graduação brasileira, a atividade ainda parece ser orientada por conhecimentos tácitos, tanto por parte das instituições de ensino e fomento, quanto pelos orientadores que se constituem como os principais responsáveis pelo desenvolvimento das atividades de IC. Talvez, como discutido por Filipecki e colaboradores (2006), haja um entendimento, ou senso comum entre os pesquisadores, de que o simples fato do bolsista se engajar em atividades de pesquisa seja bom para a sua formação.

Já a extensão universitária tem seus objetivos ainda em disputa por ser uma atividade bem mais recente nas universidades. Esses objetivos hoje são pautados em um processo de luta promovida pelos movimentos sociais e pelo importante trabalho do Fórum de Pró-Reitores de Extensão das Universidades Públicas. É possível que essa luta por uma nova concepção de extensão universitária, que supere uma visão de mera transmissão do conhecimento, resulte em editais que estabeleçam a priori, por parte da instituição ou agência financiadora, os critérios de seleção e planos de trabalho dos bolsistas.

Essa nova visão de extensão universitária, onde a produção do conhecimento deve ocorrer em diálogo com a sociedade, ganha força no 
mesmo período em que, a nível internacional, ocorre o debate sobre novos sentidos do ensino de ciências. De acordo com Cazelli e Vergara (2007),

Durante a década de 1980, um número considerável de países e a Organização das Nações Unidas para a Educação, Ciências e Cultura (UNESCO) assumiram um compromisso internacional no que diz respeito à educação em ciências: uma nova meta sob o antigo slogan "ciência para todos". (CAZELLI e VERGARA, 2007, p. 1).

Como já discutido no capítulo anterior, é nesse contexto que são criados no Brasil vários museus e centros de ciências com projetos voltados para a alfabetização científica. O Espaço COPPE, Museu da Vida e o ECV foram criados dentro desse contexto. Desta forma, tanto o movimento que levou ao fortalecimento da extensão como uma importante função da universidade, quanto o que levou à criação de novos museus de ciência, convergem com a ideia de que o conhecimento científico deve não apenas se tornar acessível à população em geral, mas que essa população deve participar dos processos políticos de tomadas de decisão.

Essas aproximações entre contexto histórico e objetivos levam ao entendimento de que os museus de ciências ligados às universidades são (ou deveriam ser) espaços intrinsecamente voltados às atividades de extensão, o que dá sentido ao fato de constatar a existência de mais bolsistas dessa modalidade nesses espaços. Entretanto, como observado nas falas dos entrevistados, em alguns casos ainda é preciso superar a visão de extensão que se limite à transmissão do conhecimento. Paula (2013) lembra que:

É tarefa da universidade para a sociedade, dialogar com ela, tentar responder às suas demandas e expectativas, reconhecer a sociedade, em sua diversidade, tanto como sujeito de direitos e deveres, quanto como portadora de valores e culturas tão legítimos quanto aqueles derivados do saber erudito. É tarefa da extensão construir a relação de compartilhamento entre o conhecimento científico e tecnológico produzido na universidade e os conhecimentos de que são titulares as comunidades tradicionais. É tarefa da extensão a promoção da interação dialógica, da abertura para alteridade, para a diversidade como condição para a autodeterminação, para a liberdade, para a emancipação (PAULA, 2013, p. 20).

Além de uma visão de extensão universitária que supere uma visão de mera transmissão do conhecimento produzido, é preciso superar a visão de alfabetização científica em que o museu enxerga o seu público como não detentor de saberes sobre a ciência. Como apontado por Cazelli, Marandino e Studart (2003), atualmente entende-se que os processos 
educacionais e comunicacionais em museus de ciência devem seguir abordagens críticas e culturais e uma perspectiva que considere a constante negociação entre o visitante e a exposição.

Parece imprescindível, portanto, que a formação dos bolsistas que atuam na mediação desses espaços considere a produção do conhecimento científico como histórico e culturalmente situado e que o papel da universidade e dos museus é o de construir um ensino de ciências pautado no diálogo entre o conhecimento acadêmico e os saberes do público. Nesta perspectiva, o bolsista terá então papel chave no processo de mediação entre o conhecimento produzido pela academia e o trazido pelo público dos museus. 


\section{7. \\ Considerações Finais}

A compreensão sobre os tipos de formação que ocorrem durante o estágio de alunos de ensino médio e graduação em museus de ciências exigiu, em primeiro lugar, um investimento teórico que possibilitou o entendimento dos espaços museais como locais para a produção de conhecimento.

Os museus de ciência sofreram mudanças ao longo da história em relação às suas funções, que originalmente enfocavam a coleção, conservação e estudo dos objetos e cada vez mais passaram a ser um local destinado também à educação. É possível afirmar que a dimensão educativa é, portanto, a função mais recente e que essas atribuições podem hoje sofrer disputas e resistências por parte dos profissionais dessas instituições.

Nesta pesquisa, pretendeu-se olhar para o museu como um espaço produtor de conhecimento, mas, mais do que isso, formativo para os alunos bolsistas. A ideia inicial era compreender como as instituições museais poderiam contribuir a formação de pesquisadores, a partir da iniciação científica. Entretanto, a ida ao campo revelou a existência de outros caminhos formativos, como a extensão universitária, no caso dos museus ligados às universidades e até mesmo de programas com objetivos próprios e desenvolvidos no interior das instituições.

O caminho da pesquisa foi então ampliado, para que fosse possível entender como ocorrem esses processos formativos, o que há de particular nessas ações e se dialogavam com a função educativa dos museus.

Para que esse novo caminho fosse construído, considerando a escassez de pesquisas que olhem para o museu como espaço produtor de conhecimento e formação, bem como sobre a iniciação científica como processo pedagógico para a formação de pesquisadores, foram feitas algumas opções teóricas. 
A reflexão inicial sobre o que é ciência, do ponto de vista epistemológico, foi importante como arcabouço teórico para compreender que, dentro de uma visão kuhniana, novos pesquisadores se formam a partir da vivência em grupos que produzem conhecimento dentro de uma determinada área ou disciplina. O diálogo com os Estudos de Laboratório de Latour possibilitou a compreensão de que para entender a ciência é preciso, mais do que ouvir os que pensam os cientistas, olhar para o fazer científico cotidiano. Este fazer é carregado de significações próprias do meio em que são gerados novos fatos que são acordados entre os atores envolvidos, no caso, os pesquisadores. A reflexão desenvolvida no capítulo 2 sobre o significado do fazer científico, relacionada mais a frente, no capítulo 6, com a noção de campo científico de Bourdieu, foi essencial para a compreensão da iniciação científica como processo formativo.

O entendimento histórico sobre a produção de conhecimento científico no Brasil permitiu conhecer onde e como são formados novos pesquisadores. Dentro da historiografia oficial, as universidades públicas e institutos de pesquisa são protagonistas como espaço de produção científica e, portanto, na formação de pesquisadores. As universidades, em especial, se constituíram como um espaço para a formação de novos cientistas, o que se consolidou com a organização institucional da pósgraduação no Brasil. Nesse contexto, a iniciação científica surge como política brasileira de incentivo à formação de novos pesquisadores e para a aceleração da formação de doutores em nosso país. A IC também fortalece a perspectiva de que ensino e pesquisa devem caminhar juntos durante a graduação. No desenvolvimento da investigação aqui apresentada, vale lembrar que foram essencialmente museus ligados a uma universidade e a institutos de pesquisa que possuíam alunos bolsistas.

Uma outra questão importante que emergiu no levantamento teórico foi o entendimento de que as agências de fomento, por meio de editais e normatização de bolsas, influenciam a IC como processo de formação, uma vez que determinam os critérios para a distribuição dessas bolsas, estipulam a forma como os resultados do trabalho devem ser apresentados (jornadas científicas, relatórios) e avaliados. 
Apesar da influência das agências de fomento na determinação de diretrizes formativas na IC, as poucas pesquisas na área mostram que boa parte desse processo depende de fato das tomadas de decisão e perspectivas de formação de cada orientador. Cabe destacar também que a existência dessas agências e a concessão de verbas e bolsas configurase como aspecto fundamental para que o estágio em museus ocorra, considerando que todas as instituições que afirmaram no questionário que não possuíam bolsistas declararam o desejo pela presença desses alunos, mas esbarraram na falta de recursos.

O contato com a história dos museus em geral, e dos museus de ciência em particular, também foi importante para a compreensão dessas instituições como espaço para a produção de conhecimento e de formação de pesquisadores, em especial pesquisadores no campo da educação em museus.

Nesse sentido, cabe a reflexão de que a educação em museus pode se configura como um campo de conhecimento novo. Considerando a pouca inserção deste campo em construção em cursos de graduação e grupos de pesquisa em programas de pós-graduação, os museus são espaços protagonistas para a formação de pesquisadores nessa área.

Para a análise dos processos formativos foram utilizadas categorias e atributos valorizados nas pesquisas que pretendem caracterizar as particularidades no desenvolvimento da iniciação científica, como os critérios de seleção, as tarefas atribuídas aos alunos bolsistas, a apresentação dos resultados do estágio e os mecanismos de avaliação.

Neste ponto, é necessário discutir sobre os limites metodológicos desta investigação. Mediante à falta de estudos sobre a iniciação científica em museus, optou-se pelo uso de um questionário para o levantamento das instituições que possuíam esse tipo de bolsista. Entretanto, a escolha desse instrumento mostrou-se em parte limitante, porque a ida a campo para as entrevistas revelou que algumas instituições possuíam na verdade bolsas de outra natureza.

Optou-se então por redimensionar os objetivos iniciais, abarcando a compreensão do estágio em museus de uma forma mais ampla, não se limitando ao estágio realizado por bolsistas de IC. O roteiro de entrevista 
foi reformulado, mas manteve alguns atributos definidos a partir do referencial teórico relacionado à formação na IC, bem como a intenção de compreender a relação desta formação com as atividades educativas e a mediação em museus.

Além disso, é preciso discutir que a escolha por entrevistar os responsáveis pelos alunos bolsistas também traz limitações para a compreensão sobre a forma como os processos formativos de fato ocorrem nessas instituições. Esse entrave decorre, em parte, pelos próprios limites da entrevista como instrumento de coleta de dados e, por outro lado, pelo conteúdo das entrevistas representar apenas a visão de parte dos formadores e não considerar a visão dos alunos e nem como o processo ocorre de fato.

Considero que para uma melhor compreensão sobre como esses processos formativos, a adoção de outras metodologias configura-se como possibilidade para estudos futuros, como: entrevistas com os alunos bolsistas, acompanhamento das atividades desenvolvidas por esses alunos através de observações no campo e a análise dos materiais produzidos durante os estágios, como relatórios e anais das jornadas e eventos científicos.

Apesar dos limites metodológicos desta investigação, avalio que foi dado um importante passo para a compreensão dos museus de ciência como espaço de formação de alunos bolsistas. As pesquisas sobre educação em museus costumam ter como foco a relação dessas instituições com o público ou sobre como os diferentes públicos aprendem nos espaços expositivo, mas olham pouco para a formação dos alunos que fazem estágio nos museus.

Sobre a formação dos alunos bolsistas nessas instituições, as pesquisas tendem a investigar apenas a sua formação como mediadores, mas consideram pouco que esse bolsista é um aluno de ensino médio ou de graduação. Também não costumam contemplar outras dimensões formativas que o estágio em museus possui e que vão além da mediação. Nesse sentido, os dados levantados permitem um avanço na compreensão dos museus como um espaço para a formação de alunos na iniciação científica e na extensão universitária. 
Assim, a análise feita a partir das entrevistas permitiu inicialmente caracterizar de forma mais descritiva os estágios nos museus de ciência da cidade do Rio de Janeiro. Como recorrências, pode-se destacar a pouca importância dada ao mérito acadêmico como critério de seleção dos bolsistas. Em geral, os museus tendem a valorizar o interesse dos alunos pelo estágio. Durante a seleção, também há uma valorização do curso de graduação de origem, o que provavelmente está relacionado ao interesse pelos saberes disciplinares que o aluno trará consigo para a instituição.

As atividades atribuídas aos bolsistas durante o estágio parecem variar de acordo com o tipo de bolsa recebida. No caso dos bolsistas de IC, em geral os planos de trabalho são acordados diretamente entre orientadores e alunos. Já os bolsistas de extensão iniciam o estágio com um plano de trabalho pré-determinado por exigência dos editais. Em todas as instituições estudadas há uma preocupação de que os alunos participem de jornadas e eventos científicos, o que só não ocorre quando há uma limitação de verbas.

Mais uma vez a questão do financiamento e fomento precisa ser destacada como aspecto relevante para o processo formativo, considerando a importância dessa vivência acadêmica para a formação tanto na IC como na extensão. Nesses eventos os bolsistas têm a oportunidade de apresentar seus resultados e, mais do que isso, vivenciar parte da cultura acadêmica da convivência e troca com pares do seu campo de conhecimento. $\mathrm{Na} I C$, as jornadas internas também funcionam como momento avaliativo.

A produção dos alunos durante o estágio também é registrada em relatórios, que ao mesmo tempo assumem o papel de instrumento avaliativo, tanto para a instituição, quanto para o aluno. Entretanto, os relatórios costumam ser pontuais e elaborados ao final do processo. Parte dos entrevistados parece concordar com a necessidade de que sejam criadas estratégias para que as avaliações sejam feitas ao longo do estágio e de forma que o aluno tenha liberdade de se colocar. Esse tipo de avaliação permite que o processo formativo seja repensado e aprimorado.

A análise dos processos formativos em diálogo com os referenciais teóricos permitiu a reflexão de que para que haja a formação de 
pesquisadores é imprescindível que o aluno se envolva em atividades de pesquisa, onde se familiarize com as etapas do fazer científico. Nesse processo, o aluno será orientado por um pesquisador ou por outros alunos mais experientes.

Como discutido ao longo da investigação, é a ligação da formação com as atividades de pesquisa que determinam a formação de novos pesquisadores e não necessariamente o tipo da bolsa concedida. A partir das entrevistas, pode-se perceber que independentemente da natureza da bolsa, em algumas instituições são formados profissionais e pesquisadores do campo da educação em museus, campo que pode ser considerado novo e emergente.

Não foi possível constatar diferenças formativas claras em relação aos bolsistas de iniciação científica de ensino médio vinculados ao PIC Jr. do Colégio Pedro II. Não parece que sejam consideradas especificidades dessa etapa de formação nas atividades desenvolvidas no estágio. Entretanto, o objetivo do programa de familiarizar e aproximar o aluno de um ambiente acadêmico e profissional parece ser cumprido. Só não foi constatado o diálogo entre a educação básica e o ensino superior, sendo as escolhas do colégio, como os processos de seleção, desconhecidos pelos profissionais dos museus. Para uma melhor caracterização do PIC Jr. como IC-EM, seria necessário entrevistar também os responsáveis pelo programa no Colégio Pedro II.

No que se refere à relação do estágio com as atividades de mediação, é possível perceber que essa relação depende das concepções sobre educação de cada museu e de sua organização setorial. Nos museus fundados a partir da década de 1980, cuja principal atribuição é a educação em ciências, a mediação é uma das atividades inerentes ao estágio e em geral dialoga com as demais dimensões formativas. Nos museus em que há uma divisão setorial mais clara, onde existam setores com outras funções que não estejam diretamente ligadas à educação, os bolsistas não participam das atividades de mediação.

Uma questão emergente na análise das falas foi o entendimento por parte de alguns profissionais entrevistados de que o estágio dos alunos de graduação dialoga com a formação inicial de professores. Para esses 
profissionais, a formação dos alunos nos museus permite que o aluno tenha contato com outras visões sobre a ciência; perceba a educação em museus como um espaço para a atuação profissional. Além disso, há uma compreensão de que mesmo que esse estagiário atue futuramente no ensino formal, ele terá uma formação mais diversificada e reconhecerá os museus como um espaço para a aprendizagem dos seus alunos.

O questionário enviado aos demais museus do país permitiu perceber recorrências em relação às estratégias de seleção, formação, avaliação e relação com as atividades de mediação identificadas nas entrevistas. Foi possível verificar uma concentração de bolsas na região Sudeste, região que também concentra a maior parte de universidades e centros de pesquisa do país. Cabe destacar que a maior parte dos museus que responderam ao questionário, e todos os que foram investigados a partir das entrevistas, estão ligados a universidades ou centros de pesquisa.

O tipo de bolsa mais ofertada pelos museus ligados às universidades foi a de extensão universitária. A extensão é a dimensão mais recente do tripé universitário e, portanto, seus sentidos ainda encontram fortes disputas. Embora o Fórum de Pró-reitores de Extensão das Universidades Públicas reconheça a extensão como uma dimensão universitária onde o ensino e a produção de conhecimento deva ser realizado em diálogo com a sociedade, ainda há ações extensionistas que são feitas dentro de uma visão tradicional, onde cabe à universidade transmitir ao público o conhecimento gerado pela pesquisa acadêmica. Ambas as visões de extensão em disputa foram verificadas nos museus estudados.

A reflexão sobre a história da extensão universitária e sobre o debate dos museus de ciência como espaço de alfabetização científica leva a um entendimento de que faz sentido que os museus de ciência sejam espaços para uma visão de extensão que tenha como principal foco o diálogo entre o conhecimento científico e a sociedade (público), e no qual a produção do conhecimento e o ensino caminhem juntos. Cabe a reflexão de que a iniciação científica e a extensão universitária são dois processos formativos que podem acontecer juntos e que os museus de ciência parecem ser um espaço potente para que essas diferentes formações aconteçam juntas e/ou em diálogo. 


\section{8. Referências bibliográficas}

AFONSO, J. C.; SANTOS, N. P. Instituto de Química da UFRJ - 50 anos. $1^{\text {a }}$ ed. Rio de Janeiro: Instituto de Química/UFRJ, 2009.

ALENCAR, V. P. O mediador cultural : considerações sobre a formação e profissionalização de educadores de museus e exposições de arte. São Paulo. 2008. 97f. Dissertação (Mestrado em Artes) - Instituto de Artes, Universidade Estadual Paulista.

ALMEIDA, G. S. B.; HERENCIA, J. L. A Fundação Vitae e seu legado para a cultura brasileira - Parte I: fontes conceituais, linhas diretivas, programas próprios e legado. In: III SEMINÁRIO INTERNACIONAL DE POLÍTICAS CULTURAIS. Anais...Rio de Janeiro: Casa de Rui Barbosa, 2012. p. 1-13. BARIANI, I. C. D. Estilos cognitivos de universitários e iniciação científica. Campinas, 1998. Tese (Doutorado em Educação) - Faculdade de Educação, Universidade Estadual de Campinas.

BARROS, M. G. DE L.; SILVA, C. M. G. F. Formação inicial de professores em foco: a contribuição dos museus e centros de ciências sob a visão dos licenciandos. In: VIII ENCONTRO NACIONAL DE PESQUISA EM EDUCAÇÃO EM CIÊNCIAS. Anais...Campinas: Associação Brasileira de Pesquisa em Educação em Ciências, 2011. Disponível em: $<$ http://www.nutes.ufr.br/abrapec/viiienpec/resumos/R0828-3.pdf> BESSA, E. Desenvolvimento de um projeto científico prático em biotecnologia para alunos do ensino médio. Rio de Janeiro, 2015. 102 p. Dissertação (Mestrado em Formação Científica para Professores de Biologia) - Instituto de Biofísica, Universidade Federal do Rio de Janeiro. BEVILAQUA, D. V. Apresentação. In: BEVILAQUA, D. V. et al. (Eds.). . Museu da Vida: ciência e arte em Manguinhos. $1^{\text {a }}$ ed. Rio de Janeiro: Casa de Oswaldo Cruz (Fiocruz), 2017. p. 10-11.

BEVILAQUA, D. V.; RAMALHO, M.; ALCÂNTARA, R.; COSTA, T. Museu da Vida: ciência e arte em Manguinhos. $1^{\text {a }}$ ed. Rio de Janeiro: Casa de 
Oswaldo Cruz (Fiocruz), 2017.

BOURDIEU, P. O poder do simbólico. Rio de Janeiro: Editora Bertrand Brasil, 1989.

Os usos sociais da ciência: por uma sociologia clínica do campo científico. São Paulo: eDITORA unesp, 2004.

BRANDÃO, C. R. F.; COSTA, C. Uma crônica da integração dos museus estatutários à USP. Anais do Museu Paulista, v. 15, n. 1, p. 207-217, 2007.

BRASIL. Lei n. 5.540 de 28 de novembro de 1968. Fixa normas de organização e funcionamento do ensino superior e sua articulação com a escola média, e dá outras providências. Brasília, DF, 1968.

. Lei no 9394 de 20 de dezembro de 1996. Estabelece as diretrizes e bases da educação nacional. Brasília, DF, 1996.

BRASIL. CAPES. Portaria n⿳080 de 16 de dezembro de 1998. Dispõe sobre o reconhecimento dos mestrados profissionais e dá outras providências., 1998.

BRASIL. COMISSÃO ESPECIAL DESTINADA A PROMOVER ESTUDOS E PROPOSIÇÕES PARA A REFORMULAÇÃO DO ENSINO MÉDIO CEENSI. Projeto de lei $\mathbf{n}^{\circ} \mathbf{6 8 4 0}$ de $\mathbf{2 7}$ de novembro de 2013. Altera a Lei $n^{\circ}$ 9.394, de 20 de dezembro de 1996, para instituir a jornada em tempo integral no ensino médio, dispor sobre a organização dos currículos do ensino médio em áreas do conhecimento., 2013.

BRASIL. CONSELHO NACIONAL DE PESQUISA E DESENVOLVIMENTO TECNOLÓGICO. Resolução Normativa n¹7 de 13 de julho de 2006. Estabelece regras para a concessão de bolsas, 2006.

BRASIL. MINISTÉRIO DA EDUCAÇÃO. Decreto n 19851 de 11 de abril de 1931. Estabelece as bases do sistema universitário brasileiro, 1931. BRASIL. MINISTÉRIO DA EDUCAÇÃO. SECRETARIA DE EDUCAÇÃO SUPERIOR. FÓRUM DE PRÓ-REITORES DE EXTENSÃO DAS UNIVERSIDADES PÚBLICAS BRASILEIRAS. Plano Nacional de Extensão Universitária, 1999.

Extensão Universitária: Organização e Sistematização. Belo Horizonte: COOPMED, 2007.

BRASIL. PRESIDÊNCIA DA REPÚBLICA. Lei n 13415 de 16 de fevereiro 
de 2017. Altera as Leis nos 9.394, de 20 de dezembro de 1996 e institui a Política de Fomento à Implementação de Escolas de Ensino Médio em Tempo Integral, 2017.

BRID, J. C. A.; PEREIRA, E. M. P. O Impacto da Iniciação Científica na Formação Universitária. Olhar de Professor, v. 7, n. 2, p. 77-88, 2004.

BRITTO, J. P. Museu, entre o que guarda e o que mostra. In: SEMEDO, A.; LOPES, J. T. (Eds.). Museus, dicursos e representações. Porto: Edições Afrontamento, 2005. p. 149-199.

CAFFAGNI, C. W. A. O Estudo das Analogias Utilizadas como Recurso Didático por monitores em em Centro de Ciência e Tecnologia de São Paulo - SP. São Paulo, 2010. 207 p. Dissertação (Mestrado em Educação) - Faculdade de Educação, Universidade de São Paulo.

CARVALHO, C. Espaços de cultura e formação de professores/monitores. In: LEITE, M. I.; OSTETTO, L. E. (Eds.). Museus, educação e cultura: encontros de crianças e professores com a arte. Campinas: Papirus Editora, 2005. p. 117-139.

Quando a escola vai ao museu. $1^{\mathrm{a}}$ ed. Campinas: Papirus Editora, 2016.

CAZELLI, S.; QUEIROZ, G.; ALVES, F.; FALCÃO, D.; VALENTE, M. E.; GOUVÊA, G.; COLINVAUX, D. Tendências pedagógicas das exposições de um museu de ciências. In: GUIMARÃES, V.; SILVA, G. A. (Eds.). Implantação de centros e museus de ciência. Rio de Janeiro: UFRJ, 2002. p. 208-218.

CAZELLI, S.; COIMBRA, C. A. Q.; GOMES, I.; VALENTE, M. E. Inclusão social e a audiência estimulada em um museu de ciência. Museologia \& Interdisciplinaridade, v. V, n. 7, 2015.

CAZELLI, S.; MARANDINO, M.; STUDART, D. Educação e comunicação em museus de Ciências: aspectos históricos, pesquisa e prática. In: GOUVÊA, G.; MARANDINO, M.; LEAL, M. C. (Eds.). Educação em Museus: a construção social do caráter educativo dos museus de ciências. Rio de Janeiro: Acess, 2003. p. 83-106.

CAZELLI, S.; VALENTE, M. E.; ALVES, F. Alfabetismo científico: um movimento recorrente e mutável. In: GUIMARÃES, V. F.; SILVA, G. A. (Eds.). Workshop: Educação museus e centros de ciência. Rio de 
Janeiro: VITAE, 2003. p. 27-43.

CAZELLI, S.; VERGARA, M. D. R. O passado e o presente das práticas de educação não formal na cidade do Rio de Janeiro. In: I ENCONTRO DE HISTÓRIA DA EDUCAÇÃO DO ESTADO DO RIO DE JANEIRO. Anais...Niterói: Universidade Federal Fluminense. 2007. p. 1-15.

CERATI, T. M. Educação em Jardins Botânicos na Perspectiva da Alfabetização Científica: Análise de uma Exposição e Público. São Paulo, 2014. 254 p. Tese (Doutorado em Educação) - Faculdade de Educação, Universidade de São Paulo.

CHALMER, A. F. O Que é Ciência Afinal? São Paulo: Brasiliense, 1993.

COUTINHO-SILVA, R.; PERSECHINI, P. M.; MASUDA, M.; KURTENBACH, E. Interação museu de ciências-universidade: contribuições para o ensino não-formal de ciências. Ciência e Cultura, v. 57, n. 4, p. 24-25, 2005.

DAMASCENO, M. N. A Formação de Novos Pesquisadores: a investigação como construção coletiva a partir da relação teoria-prática. In: CALAZANS, M.; JULIETA (Eds.). . Iniciação Científica: construindo o pensamento crítico. $2^{a}$ ed. São Paulo: Cortez, 2002. p. 13-55.

DUARTE, R. Entrevistas em pesquisas qualitativas. Educar em Revista, n. 24, p. 213-225, 2004.

FERREIRA, M. S. Iniciação científica no ensino médio: reflexões a partir do campo do currículo. In: FERREIRA, M. C. (Ed.). Juventude e Iniciação Científica: políticas públicas para o ensino médio. 1a ed. Rio de Janeiro: EPSJV, UFRJ, 2010. p. 229-237.

FERREIRA, I. Objetos mediadores em museus. Midas, v. 4, p. 1-15, 2014. FILIPECKI, A.; BARROS, S. D. S.; ELIA, M. D. F. A visão dos pesquisadores-orientadores de um programa de vocação científica sobre a iniciação científica de estudantes de ensino médio. Ciência \& Educação, v. 12, n. 2, p. 199-217, 2006.

FOPROEX. Avaliação nacional da extensão universitária: pressupostos, indicadores e aspectos metodológicos, 2000.

FREIRE, P. Extensão ou Comunicação? $1^{\text {a }}$ ed. Editora Paz e Terra, 2013. GATTI, B. A. Reflexão sobre os desafios da pós-graduação: novas perspectivas sociais, conhecimento e poder. Revista Brasileira de 
Educação, n. 18, p. 108-116, 2001.

GOMES, I. L. Formação de mediadores em museus de ciência. Rio de Janeiro, 2013. 140 p. Dissertação (Mestrado em Museologia e Patrimônio). Universidade Federal do Estado do Rio de Janeiro ; MAST.

GOMES, I. L.; CAZELLI, S. Formação de mediadores em museus de ciência: diálogos entre a educação formal e não formal. Revista Educação Online (PUC-Rio), v. 16, p. 1-22, 2014.

. Formação de mediadores em museus de ciencia: saberes e práticas.

Revista Ensaio, v. 18, p. 23-46, 2016.

GONÇALVES, M. D. L.; VERGARA, M. D. R. O Espaço Coppe Miguel de Simoni na discussão entre museus e centros de ciência . Anais do Museu Histórico Nacional, v. 44, p. 73-90, 2012.

GOUVÊA, F.; MENDONÇA, A. W. P. C. A contribuição de Anísio Teixeira para a institucionalização da Pós-graduação no Brasil: um percurso com os boletins da CAPES. Perspectiva, v. 24, n. 1, p. 111-132, 2006.

HANDFAS, E. R.; GRANATO, M.; LOURENÇO, M. C. MUSEUS DE CIÊNCIA E TECNOLOGIA DA UNIVERSIDADE FEDERAL DO RIO DE JANEIRO: três experiências. In: GRANATO, M. (Ed.). Anais do IV Seminário Internacional Cultura Material e Patrimônio da Ciência e Tecnologia. Rio de Janeiro: Museu de Astronomia e Ciências Afins, 2016. p. 42-64.

HOCHMAN, G. A ciência entre a comunidade e o mercado: leituras de Kuhn, Bourdieu, Latour e Knorr-Cetina. In: PORTOCARRERO, V. (Ed.). Filosofia, História e Sociologia das Ciêcias: Abordagens Contemporâneas. Rio de Janeiro: Editora Fiocruz, 1994. p. 199-232.

INSTITUTO BRASILEIRO DE MUSEUS. Guia dos Museus Brasileiros. Brasília: Instituto Brasileiro de Museus, 2011.

JACOBUCCI, D. F. C. Contribuições Dos Espaços Não-Formais De Educação Para a Formação Da Cultura Científica. Em Extensão, v. 7, p. 55-66, 2008.

JACOBUCCI, D. F. C.; JACOBUCCI, G. B.; NETO, J. M. Experiências de formação de professores em centros e museus de ciências no Brasil. Revista Electrónica de Ensenanza de las Ciências, v. 8, n. 1, p. 118136, 2009. 
KROPF, S. P.; FERREIRA, L. O. A prática da ciência: uma etnografia no laboratório. História, Ciências, Saúde-Manguinhos, v. IV, n. 3, p. 589597, 1998.

KUHN, T. A estrutura das revoluções científicas. $12^{\mathrm{a}}$ ed. São Paulo: Editora Perspectiva, 2013.

LATOUR, B.; WOOLGAR, S. A Vida do Laboratório, a produção dos fatos científicos. Rio de Janeiro: Relume Dumara, 1997.

LIBÂNEO, J. C. Didática. São Paulo: Cortez, 1991.

LOPES, M. M. O Brasil descobre a pesquisa - os museus e as ciências naturais no século XIX. $2^{\mathrm{a}}$ ed. São Paulo: HUCITEC, 2009.

MARANDINO, M. Educação em museus: a mediação em foco. São Paulo: FEUSP, 2008.

MARANDINO, M.; SELLES, S.; FERREIRA, M. S. Ensino de Biologia: histórias e práticas em diferentes espaços educativos. $1^{a}$ ed. São Paulo: Cortez, 2009.

MARTINS, C. B. A reforma universitária de 1968 e a abertura para o ensino superior privado no Brasil. Educação \& Sociedade, v. 30, n. 106, p. 1535, 2009.

MARTINS, G. Formação Científica e Ensino Médio. Rio de Janeiro, 2003. Dissertação (Mestrado em Educação em Ciências e Saúde) - Nucleo de Tecnologia Educacional para a Saúde, Universidade Federal do Rio de Janeiro.

MARTINS, L. C. A Constituição da Educação em Museus: o funcionamento do dispositivo pedagógico por meio de um estudo comparativo entre museus de artes, ciências humanas e ciência e tecnologia. São Paulo, 2011. 390 p. Tese (Doutorado em Educação) Faculdade de Educação, Universidade de São Paulo.

MASSI, L.; QUEIROZ, S. L. ESTUDOS SOBRE INICIAÇÃO CIENTÍFICA NO BRASIL : UMA REVISÃO. Cadernos de Pesquisa, v. 40, p. 173-197, 2010.

Iniciação Científica: aspectos históricos, organizacionais e formativos da atividade no ensino superior brasileiro. $1^{\text {a }} \mathrm{ed}$. São Paulo: Editora da UNESP, 2015.

MATOS, M.; MACIEL, C. M.; LIMA, I. V.; VILELA, M. Iniciação Científica 
Júnior na escola: Desafios e possibilidades. In: VI ENCONTRO REGIONAL DE ENSINO DE BIOLOGIA DA REGIONAL 02 (RJ/ES). Anais...Rio de Janeiro: Universidade Federal Fluminense, 2012.

MATTEDI, M. A. A sociologia da pesquisa científica : o laboratório científico como unidade de análise sociológica. Teoria \& Pesquisa, v. XVI, n. 2, p. 51-70, 2007.

McMANUS, P. Topics in museums and science education. Studies in Science Education, v. 20, p. 157-182, 1992.

MOITA, F. M. G. DA S. C.; ANDRADE, F. C. B. Ensino-pesquisa-extensão : um exercício de indissociabilidade na pós-graduação. Revista Brasileira de Educação, v. 14, n. 41, p. 269-280, 2009.

MOURA, M. L. S. DE; FERREIRA, M. C. Projeto de Pesquisa Elaboração, Redação e Apresentação. Rio de Janeiro: EdUERJ, 2005. NEVES, R. M. Pedagogia da Pesquisa: incidências sobre a formação do cientista. In: $30^{A}$ REUNIÃO ANUAL DA ANPED. Anais...Caxambu: ANPED, 2007. p. 1-17.

NEVES, R. M. Lições da iniciação científica ou a pedagogia do laboratório. História, Ciências, Saúde-Manguinhos, v. 8, n. 3, p. 71-97, 2001.

OHAYON, P.; AQUINO, L.; MARAVALHAS, A. L. G.; SANTOS, B. M.; BARRETO, E. A.; BEZERRA, M. J. S. Iniciação científica : uma metodologia de avaliação. Ensaio: Avaliação e Políticas Públicas em Educação, v. 15, n. 54, p. 127-144, 2007.

OLIVA, A. Kuhn: o normal e o revolucionário na reprodução da racionalidade científica. In: PORTOCARREIRO, V. (Ed.). Filosofia, História e Sociologia das Ciêcias: Abordagens Contemporâneas. $1^{\mathrm{a}}$ ed. Rio de Janeiro: Editora Fiocruz, 1994. p. 67-102.

PADRÓ, C. Educación en museos: representaciones y discursos. In: SEMEDO, A.; LOPES, J. T. (Eds.). . Museus, dicursos e representações. Porto: Edições Afrontamento, 2005. p. 49-68.

PAIVA, K. J. M. DE; PRIMON, J. C. S. Museus no Brasil: a nova museologia e os benefícios proporcionados à prática pedagógica na escola. In: XXVII SIMPÓSIO NACIONAL DE HISTÓRIA - CONHECIMENTO HISTÓRICO E DIÁLOGO SOCIAL Anais...Natal: ANPUH, 2013. p. 1-9.

PAULA, J. A. A extensão universitária: história, conceito e propostas The 
university extension: history, concept and proposals João Antônio de Paula. Interfaces - Revista de Extensão, v. 1, n. 1, p. 05-23, 2013.

PIRES, D. DE O. 200 anos do Museu Nacional. $1^{\text {a }}$ ed. Rio de Janeiro: Associação Amigos do Museu Nacional, 2017.

POULOT, D. Museologia. In: Museu e a Museologia. Belo Horizonte: Autêntica, 2013. p. 15-81.

QUEIROZ, G. Parcerias na formação de professores de ciências na educação formal e não formal. In: SEPÚLVEDA, L. (Ed.). Caderno do Museu da Vida: $O$ formal e o não formal na dimensão educativa do museu. $1^{\text {a }}$ ed. Rio de Janeiro: Fiocruz, 2002. p. 80-86.

QUEIROZ, G.; KRAPAS, S.; VALENTE, M. E.; DAVID, E.; DAMAS, E. O Saber Da Mediação. Revista Brasileira de Pesquisa em Educação em Ciências, v. 2, n. 2, p. 77-88, 2002.

RODARI, P.; MERZAGORA, M. Mediadores em museus e centros de ciência: Status, papéis e capacitação. Uma visão geral européia. In: MASSARANI, L.; MERZAGORA, M.; RODARI, P. (Eds.). Diálogos \& ciência: mediação em museus e centros de Ciência. Rio de Janeiro: Museu da Vida/Casa de Oswaldo Cruz/Fiocruz, 2007. p. 7-20.

ROMÊO, J. R. M.; ROMÊO, C. I. M.; JORGE, V. L. Estudos de pósgraduação no brasil. UNESCO, p. 75, 2004.

ROTHEN, J. C. A universidade brasileira na Reforma Francisco Campos de 1931. Revista Brasileira de História da Educação, n. 17, p. 142-160, 2008.

SANTOS, C. M. Os Primeiros passos da pós-graduação no Brasil: a questão da dependência. Ensaio: Avaliação e Políticas Públicas em Educação, v. 10, n. 37, p. 479-492, 2002.

SCHWARTZMAN, S. Um espaço para a ciência: a formação da comunidade científica no Brasil. $4^{\mathrm{a}}$ ed. Campinas: Editora UNICAMP, 2015.

SECRETARIA DE ESTADO DE CULTURA DO RIO DE JANEIRO. Um guia de memórias e afetividades. $1^{\text {a }}$ ed. Rio de Janeiro: Secretaria de Estado de Cultura do Rio de Janeiro, 2013.

SEIBEL-MACHADO, M. I. O papel do setor educativo nos museus: análise da literatura (1987 a 2006) e a experiência do museu da vida. 
Campinas, 2009. 250 p. Tese (Doutorado em Ciências) - Instituto de Geociências, Universidade Estadual de Campinas.

SEVERINO, A. J. Pós-graduação e pesquisa: o processo de produção e sistematização do conhecimento no campo educacional. In: BIANCHETTI, L.; MACHADO, A. M. N. (Eds.). A bússola do escrever: desafios e estratégias na orientação e escrita de teses e dissertações. $3^{a}$ ed. São Paulo: Cortez, 2012. p. 82-101.

TARDIF, M. Saberes docentes e formação profissional. $11^{\mathrm{a}} \mathrm{ed}$. Petrópolis: Vozes, 2010.

TRILLA, J. A educação não-formal. In: ARANTE, V. A. (Ed.). . A educação formal e não-formal: ponstos e contrapontos. $1^{\text {a }}$ ed. São Paulo: Summus, 2008. p. 168.

VALENTE, M. E. Educação em museus: o público de hoje no museu de ontem. Rio de Janeiro, 1995. Dissertação (Mestrado em Educação) Departamento de Educação. Pontifícia Universidade Católica do Rio de Janeiro.

A conquista do caráter público dos museus. In: GUARACIRA, G.; MARANDINO, M.; LEAL, M. C. (Eds.). . Educação em Museus: a construção social do caráter educativo dos museus de ciências. Rio de Janeiro: Acess, 2003. p. 21-46.

VALENTE, M. E.; CAZELLI, S.; ALVES, F. Museus, ciência e educação: novos desafios. História, Ciências, Saúde - Manguinhos, v. 12, n. suplemento, p. 183-203, 2005. 


\section{Apêndices}

\section{Apêndice 1 - Roteiro de entrevista}

\section{Perfil do Entrevistado}

i. Qual o cargo/função do entrevistado?

ii. Qual a formação?

iii. Há quanto tempo trabalha na Instituição?

iv. Qual o vínculo com a instituição?

\section{Caracterização das atividades desenvolvidas com bolsistas na}

\section{Instituição}

v. Que tipo de bolsas são oferecidas aos alunos?

vi. Para quais segmentos são oferecidas essas bolsas (ensino médio, graduação)?

vii. Há bolsistas de IC?

viii. Desde quando essas bolsas são oferecidas na instituição?

ix. Essa oferta é contínua, houve alguma interrupção? Em caso positivo: por quê?

x. Existe um registro do quantitativo de bolsistas?

\section{Desenvolvimento das atividades de IC na Instituição}

xi. Quais os critérios de seleção dos bolsistas? (Se tiver de Graduação e Ensino Médio, há diferença nessa seleção?)

xii. A que setores do museu eles estão ligados (curadoria, educativo)?

xiii. Há tarefas atribuídas aos bolsistas? Quais são elas?

xiv. Caso haja os dois segmentos, há diferenças nas tarefas? Quais?

xv. Os bolsistas participam de Jornadas Acadêmicas na Instituição para apresentarem seus trabalhos? Com que frequência?

xvi. Há anais dessas jornadas?

xvii. Como ocorre a avaliação dos bolsistas? (Se tiver de Graduação e Ensino Médio, há diferença nessa avaliação?)

xviii. Os bolsistas avaliam sua atuação da instituição? Em caso positivo esses resultados são utilizados?

xix. Há alguma regulamentação dessas atividades na Instituição? Algum documento? 


\section{Relação das atividades com a mediação}

xx. Os bolsistas atuam também nos espaços de mediação?

xxi. Em caso positivo, há algum processo de formação para atuar nesse papel?

xxii. O trabalho de mediação está relacionado a outros possíveis trabalho que eles (bolsistas) realizam no Museu?

xxiii. O que o entrevistado acha da existência de bolsista na instituição? 


\title{
Apêndice 2 - Termo de consentimento livre e esclarecido
}

\author{
PONTIFÍCIA UNIVERSIDADE CATÓLICA DO RIO DE JANEIRO \\ Programa de Pós-Graduação em Educação \\ TERMO DE CONSENTIMENTO LIVRE E ESCLARECIDO
}

PUC

Prezado/a:

Convidamos V.S a participar voluntariamente da pesquisa apresentada a seguir.

Pesquisa:

"A Iniciação Científica em Museus de Ciências da Cidade do Rio de Janeiro"

\section{Pesquisadores:}

Doutoranda: Isabel Van Der Ley Lima | isabelvdl@gmail.com | Tel. (21) 97285-6566

Orientadora: Profa. Dra. Cristina Carvalho | cristinacarvalho@puc-rio.br | Tel. (21) 35271815

\section{Justificativas:}

A pesquisa se justifica das reduzidas investigações sobre os processos de iniciação científica no país, em especial nos espaços museais.

\section{Objetivos:}

O objetivo desta pesquisa é compreender como são desenvolvidas as atividades de iniciação científica nos museus de ciências da cidade do Rio de Janeiro

\section{Metodologia:}

Entrevistas com roteiro semi-estruturado, através de áudio-gravação, com duração média de 40 minutos.

$\mathrm{Eu}$,

de maneira voluntária, livre e esclarecida, concordo em participar da pesquisa acima identificada. Estou ciente dos objetivos do estudo, dos procedimentos metodológicos, das garantias de confidencialidade e da possibilidade de esclarecimentos permanentes sobre os mesmos. Fui informado(a) de que se trata de pesquisa de doutorado em andamento no Programa de Pós-Graduação em Educação da PUC-Rio. Está claro que minha participação é isenta de despesas e que minha imagem e meu nome não serão publicados sem minha prévia autorização por escrito. Estou de acordo com a áudio-gravação da entrevista a ser cedida para fins de registros acadêmicos. Estou ciente de que, em qualquer fase da pesquisa, tenho a liberdade de recusar a minha participação ou retirar meu consentimento, sem penalização alguma e sem nenhum prejuízo que me possa ser imputado.

$\overline{\text { Isabel Van Der Ley Lima, doutoranda. }}$ e $\overline{\text { Profa. Dra. Cristina Carvalho, orientadora. }}$

[assinatura do voluntário]

Nome completo:

E-mail: Tel. Identificação (RG):

Rio de Janeiro, de de 2016.

OBS.: Este termo é assinado em 2 vias, uma do/a voluntário/a e outra para os arquivos dos pesquisadores. 


\section{Apêndice 3 - Questionário enviado aos museus de ciência ${ }^{79}$}

\section{Ações Formativas em Museus e Centros de Ciência}

0 presente formulário visa conhecer as açōes formativas desenvolvidas em Centros e Museus de Clencia, como parte do trabalino realizado pelo Gupo de pesque realizadas nos Museus e Centros Culturais.

*obrigatório

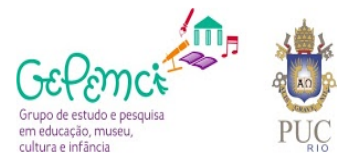

Nome da instituição *

Sua resposta

Estado *

Escolher $\checkmark$

Município *

Sua resposta

Responsável pelo preenchimento do questionário *

Sua resposta

Cargo na instituição *

Sua resposta

E-mail para contato

Sua resposta

1. A instituição possui alunos bolsistas? *

Sim

Não

\section{Caso haja alunos bolsistas}

Responda a essas questōes apenas se houver alunos bolsistas na instituiçāo

2. A qual segmento esses bolsistas estão ligados:

(Pode ser marcada mais de uma opçăo)

$\square$ Ensino Médio

Ensino Superior

$\square$ Outro:

2.1. Caso haja alunos de graduação, a quais cursos eles estão vinculados?

\author{
3. Quais tipos de bolsas são oferecidas aos alunos: \\ (Pode ser marcada mais de uma opcâo) \\ $\square$ Iniciação Científica \\ $\square$ Extensão \\ Apoio Técnico \\ $\square$ Outro:
}

Sobre os critérios de seleção dos alunos bolsitas:

4. 0 quanto cada um dos critérios abaixo é levado em consideração para a seleção do aluno?

Marque em uma escala o quanto cada critério é relevante para que o aluno candidato à bolsa seja selecionado.0 - não é um critério levado em consideração; 1 - é um critério pouco importante para a seleçẫo; 2 - a importáncia desse critério é regular; 4 - é um critério importante para a seleção; 5 é um critério muito importante para a seleção do aluno olsista.

4.1. Interesse pelo trabalho realizado

$\begin{array}{cccccccc} & 0 & 1 & 2 & 3 & 4 & 5 & \\ \begin{array}{c}\text { não é levado } \\ \text { em } \\ \text { consideraçăo }\end{array} & 0 & 0 & 0 & 0 & 0 & 0 & \begin{array}{c}\text { é muito } \\ \text { importante } \\ \text { para a seleção }\end{array}\end{array}$

4.2. Disponibilidade de horário

$\begin{array}{cccccccc} & 0 & 1 & 2 & 3 & 4 & 5 & \\ \begin{array}{c}\text { não é levado } \\ \text { em } \\ \text { consideração }\end{array} & \bigcirc & 0 & 0 & 0 & \bigcirc & 0 & \begin{array}{c}\text { é muito } \\ \text { importante } \\ \text { para a seleçăo }\end{array} \\ \end{array}$

4.3 Coeficiente de Rendimento (CR)

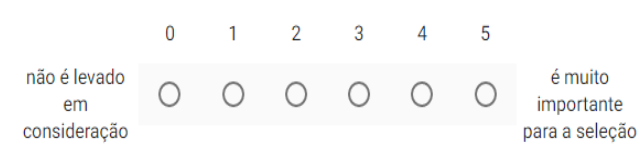

Sobre o trabalho do bolsista na instituição:

5. A quais setores da instituição esses alunos bolsistas estão ligados?

Sua resposta

6. Esses alunos participam da atividades de mediação?

$\bigcirc \operatorname{Sim}$

Não

Eventualmente

Sobre a divulgação da produção dos alunos bolsistas:

7. 0 aluno apresenta os resultados do trabalho desenvolvido na instituição?

Sim

Não

Eventualmente 
$\square$ Outro:

2.1. Caso haja alunos de graduação, a quais cursos eles estão vinculados?

Sua resposta

3. Quais tipos de bolsas são oferecidas aos alunos: (Pode ser marcada mais de uma opçâa)

$\square$ Iniciação Científica

$\square$ Extensão

\section{Sobre a avaliação dos alunos bolsistas:}

8. Os bolsistas são avaliados ao final do processo?

$\mathrm{Sim}$

Năo

Eventualmente

8.1. Caso eles sejam avaliados, qual a forma de avaliação? (Pode ser marcada mais de uma opção)

$\square$ Relatório escrito

$\square$ Parecer de avaliadores externos

$\square$ Reunião da equipe de orientadores

9. Os alunos avaliam o processo de formação?

Sim

Não

Eventualmente

9.1. Caso os alunos avaliem o processo, qual a forma de avaliação?

(Pode ser marcada mais de uma opçăo)

$\square$ Relatório escrito

$\square$ Auto-avaliaçăo

$\square$ Outro
Caso não haja alunos bolsistas

Responda a essas questōes apenas caso não haja alunos bolsistas na instituição.

3. Quais as causas para que não haja bolsistas na instituição? (Pode ser marcada mais de uma opçăo)

$\square$ Falta de interesse da instituição.

$\square$ Falta de alunos interessados.

$\square$ Falta de bolsa para os alunos.

$\square$ Falta de verbas para o desenvolvimento de projetos.

$\square$ Falta de profissionais para orientar esses alunos.

$\square$ Outro:

79 Formulário elaborado com a ferramenta Google docs. Disponível no link <https://goo.gl/forms/uRjM5cJjfxwmyY2E2>. 